JOSÉ MARIA RODRIGUES JUNIOR

\title{
FESTIVAL ESTUDANTIL SESI SOROCABA DE TEATRO
}

\author{
Dissertação apresentada ao Programa de Pós- \\ Graduação em Artes, Área de Concentração \\ Artes Cênicas, Linha de Pesquisa Teatro e \\ Educação, da Escola de Comunicação e Artes \\ da Universidade de São Paulo - ECA/SP, como \\ exigência parcial para a obtenção do título de \\ mestre em Artes, sob a orientação da Prof ${ }^{a} \mathrm{Dr}^{a}$ \\ Ingrid Dormien Koudela.
}

São Paulo

2008 
JOSÉ MARIA RODRIGUES JUNIOR

\section{FESTIVAL ESTUDANTIL SESI SOROCABA DE TEATRO}

Dissertação apresentada ao Programa de PósGraduação em Artes, Área de Concentração Artes Cênicas, Linha de Pesquisa Teatro e Educação, da Escola de Comunicação e Artes da Universidade de São Paulo - ECA/SP, como exigência parcial para a obtenção do título de mestre em Artes, sob a orientação da Prof ${ }^{a} \operatorname{Dr}^{a}$ Ingrid Dormien Koudela.

São Paulo

2008 
JOSÉ MARIA RODRIGUES JUNIOR

\section{FESTIVAL ESTUDANTIL SESI SOROCABA DE TEATRO}

Aprovado em: 120

Banca Examinadora

Prof.(a) Dr.(a).

Instituição:

Assinatura:

Prof.(a) Dr.(a).

Instituição:

Assinatura:

Prof.(a) Dr.(a).

Instituição:

Assinatura: 


\section{Resumo}

A pesquisa tem por objetivo mostrar como o Festival Estudantil fecunda as artes cênicas e instaura a participação no processo educacional, juntamente com o que ocorre no trabalho desenvolvido no Núcleo de Artes Cênicas do Sesi Sorocaba-SP. A intenção é refletir sobre a importância do teatro feito nos palcos escolares e estimular a reflexão de artistas, professoresartistas e indivíduos comprometidos com a arte, tendo como foco principal o teatro e a sua repercussão nos festivais estudantis. Para tal, foi usada a metodologia de pesquisa de campo, por meio de entrevistas a alguns grupos que participaram dos festivais de 2002 a 2008. O desenrolar da pesquisa revela que os Festivais Estudantis realizados em Sorocaba têm fornecido meios aos estudantes para agir e acreditar que são as pequenas coisas que os tornam únicos e interessantes. Eles estimulam a participação e promovem, por meio de práticas motivadoras, atitudes de alteridade, de cooperação e de conhecimento, permitindo aos jovens participar ativamente de suas responsabilidades com a escola e com a sociedade.

Palavras-chave: Teatro; Artes; Jogos Teatrais; Festivais de Teatro; Cultura; Professor-Artista; Educação. 


\begin{abstract}
The survey has the aim of showing how the Student Festivals nurture scenic arts, creating participation in the educational process, along with what is happening in the work carried out at the Núcleo de Artes Cênicas do SESI Sorocaba-SP (Scenic Arts Center from the SESI in Sorocaba). The intention is to reflect upon the importance of theater staged by school groups and to stimulate reflection on the part of artists, teacher-artists and individuals who are committed with art, with the main focus being the theater and its repercussion on student festivals. For this purpose, the field research methodology was used, by means of interviews carried out among some of the groups taking part in the 2002 to 2008 festivals. The outcome of such a survey shows that the Student Festivals held in Sorocaba have enabled students to act and to believe in the fact that small things are what make them unique and interesting. They motivate participation and foster, through motivating practices, attitudes of otherness, of cooperation and knowledge, allowing youngsters to actively participate in their responsibilities towards schools and society at large.
\end{abstract}

Key words: Theater; Arts; Theater Games; Theater Festivals; Culture; Teacherartists; Education. 


\section{DEDICATÓRIA}

\section{A Deus}

por permitir mais esta jornada

A Ingrid Dormien Koudela

por cada palavra

A Clóvis Garcia

sempre meu mestre

A Sonia Machado de Azevedo

amiga de luta

A Júlio César de Souza Martins

pelo espaço cedido

A Ligia de Paula Souza

por acreditar

Aos meus alunos do Núcleo de Artes Cênicas do SESI Sorocaba

pelo apoio constante

A João Souza

companheiro de todos os momentos

A Benedita Mosconi e José Maria Rodrigues

pais sempre presentes

A Juliana e Luciana

irmãs

A Daniela Mosko

no ideal junto

A Lorena e Julia

a força da família 
Introdução.

\section{CAPÍTULO I}

Festival Estudantil no Brasil................................................................... 14

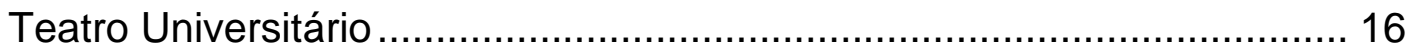

Teatro dos Estudantes de Direito do Largo São Francisco......................... 18

Teatro do Estudante do Brasil - TEB.......................................................21

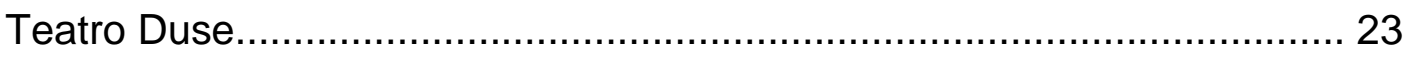

TUCA

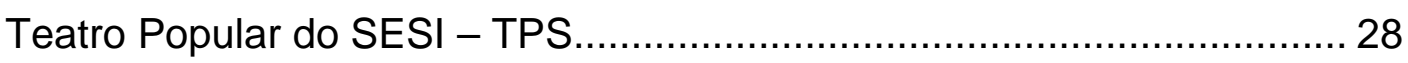

Festival Estudantil de Teatro do Estado de São Paulo...............................30

A Importância do Festival Estudantil no Estado de São Paulo..................... 30

\section{CAPÍTULO ॥}

Festival Estudantil SESI Sorocaba de Teatro.......................................... 40

1ํ Festival Estudantil SESI TV Aliança de Teatro 2002............................51

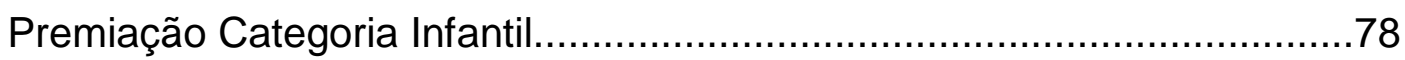

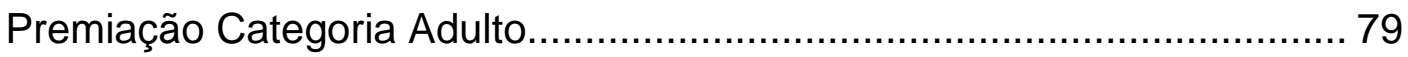

$2^{\circ}$ Festival Estudantil de Teatro SESI TV TEM 2003............................... 80

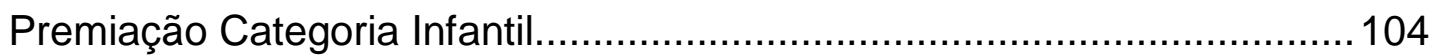

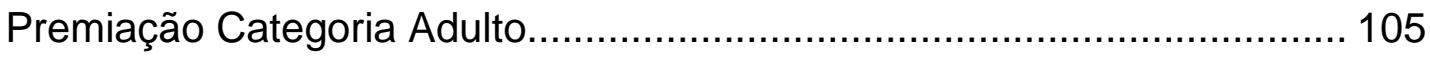

3o Festival Estudantil de Teatro 2004................................................. 106

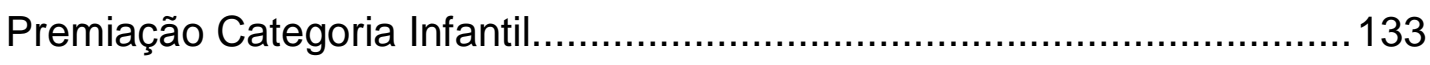

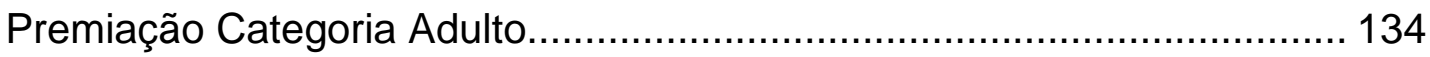

4ㅇ Festival Estudantil SESI de Teatro 2005 ........................................... 135

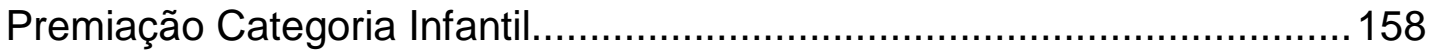

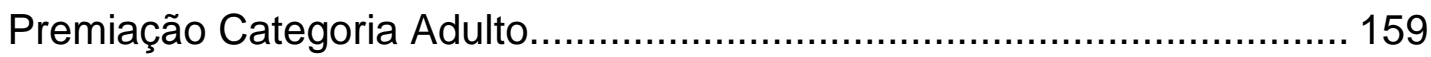

5o Festival Estudantil SESI de Teatro 2006........................................... 160

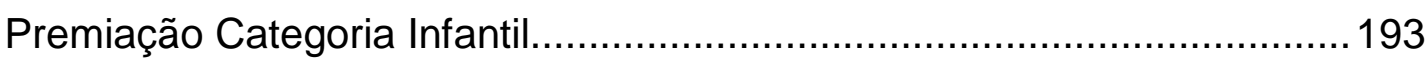

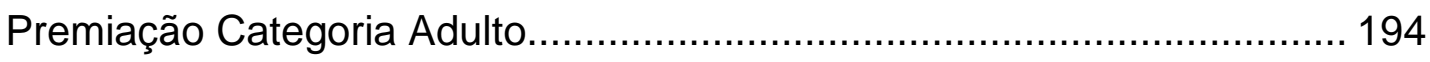

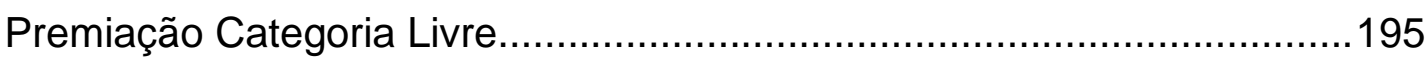


60 Festival Estudantil SESI de Teatro 2007 ............................................ 196

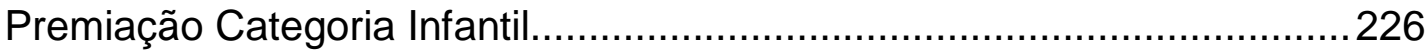

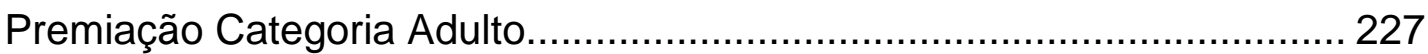

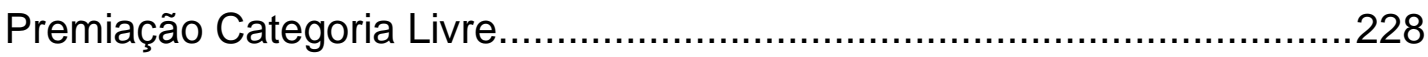

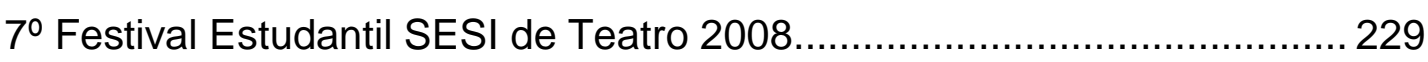

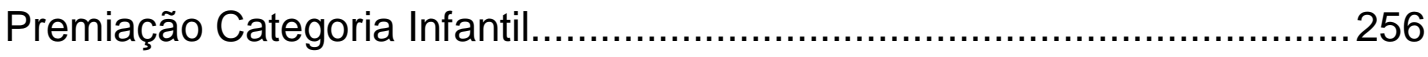

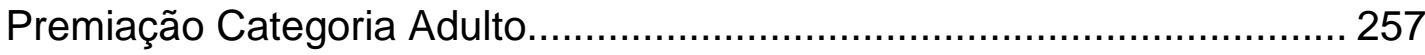

CAPÍTULO III

O Festival e a formação dos Grupos nas escolas.................................... 258

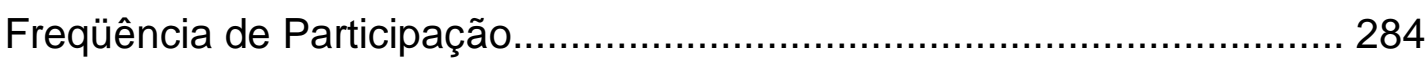

Tendência de Participação....................................................................286

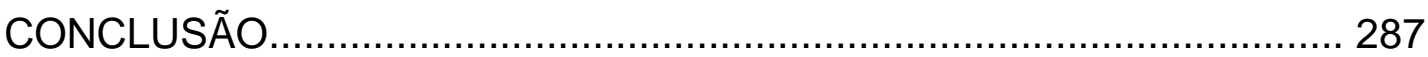

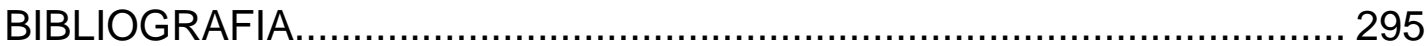


Todos os elementos que o servem - bilheteiro, porteiro, indicadores, intérpretes, cenógrafos, figurinistas, maquinistas, publicistas, costureiras, aderecistas, secretários, diretores- são estudantes. É o núcleo de um teatro escola dirigido por moços e baseado no entusiasmo, no desinteresse e no idealismo dos moços.

Pascoal Carlos Magno

\section{INTRODUÇÃO}

O teatro, particularmente pela sua condição de arte plural, multidisciplinar e pluriforme, poderá fomentar a criação de hábitos culturais e ajudar a compreender o modo como o desenvolvimento sócio-cultural local e regional é sinônimo de mudança. Tal problematização permitiu considerar 0 teatro um objeto facilitador das mudanças sócio-culturais, partindo da afirmação conjunta da tradição e da inovação, envolvendo a estética, a criação e a educação. Também permitiu considerar o teatro um instrumento de reflexão social, tornando as pessoas envolvidas ativas e criativas no seu próprio desenvolvimento e no desenvolvimento qualitativo da sua comunidade.

$\mathrm{Na}$ formação do ser humano devem coexistir dois espaços de formação que considero essenciais: o espaço formal e o não formal. Por espaço formal compreendemos o papel da escola com as regras e padrões de comportamento que conferem uma formação regulada e certificada. O espaço não formal é entendido como uma dimensão que complementa o formal. É o espaço de interação e inter-relação pautado por uma participação ativa, comprometida com o desenvolvimento e o crescimento humano. E, aqui, o teatro é uma estratégia de promoção da participação, da interação criativa de um convívio saudável, de transformação do passivo espectador em ator.

Acredito num teatro comprometido com o homem interagindo no seu tempo, vejo que ele deve acontecer fincado nos pilares da educação: o ser, o saber, o saber fazer e o aprender a fazer juntos. Um teatro assim realizado não se finda no espetáculo, ele se fixa na relação que se estabelece no processo 
de construção. E o festival estudantil vai permitir um estreitamento dessa convivência porque cada ser humano é único, logo o que vale é a possibilidade de promover a diversidade. A pluralidade cultural é vivida e vira importante instrumento para motivar, integrar e dinamizar processos que vão provocar pequenas rupturas críticas do sistema de ensino convencional, na maioria das vezes, carentes de uma pedagogia lúdica e criativa. O festival traz, a partir do teatro que envolve estudantes, professores, funcionários e família, uma aprendizagem partilhada e centrada no processo criativo.

Pretendo apresentar uma pesquisa que mostre como o Festival Estudantil fecunda as artes cênicas e instaura uma participação no processo educacional, juntamente com o que ocorre no trabalho desenvolvido no Núcleo de Artes Cênicas do SESI Sorocaba-SP.

A intenção é refletir sobre o teatro feito nos palcos escolares e estimular a reflexão de artistas, professores-artistas e indivíduos comprometidos com a arte, tendo como foco principal o teatro e a sua repercussão nos festivais estudantis.

Como exemplo de relevância dos festivais, pesquisei mais detidamente alguns grupos de teatro nascidos de escolas de ensino fundamental e médio, da rede particular e pública de ensino, em São Paulo. São eles: o grupo teen de Teatro Santo Agostinho, sob a responsabilidade da professora Pámela Larenas Paz. de Teatro Uta, da Escola E.E Dr. Afonso Vergueiro, na cidade: Salto de Pirapora-SP, sob a responsabilidade da professora Jane Kastorsky; Thiago Leite, do Grupo Trupe Cata-vento, do Colégio Anglo Boituva; Fábio Jurera do Grupo Teatral Tapanaraca, de Itapetininga e a Cia. de Teatro Tal\&Pá da Escola Estadual Professora Maria Augusta de Ávila, em Artur Alvim, Zona Leste de São Paulo, sob a responsabilidade da professora Valéria de Oliveira.

A proposta é fruto de um trabalho que nasceu em 2002 e desde então tudo o que foi feito é matéria e objeto da pesquisa, projetado em seu aspecto social e político e na pedagogia do teatro. Durante esse período, também estive envolvido e comprometido com o Núcleo de Artes Cênicas do SESISorocaba, em cujo espaço ocupei a função de orientador de artes cênicas, o que me possibilitou realizar o Festival Estudantil de Teatro. 
Nessa experiência intensa e gratificante com o trabalho que envolve crianças, adolescentes e adultos, sempre esteve presente meu sonho de menino, pois nunca deixei de acreditar que a arte caminhasse junto com 0 desejo infinito de dizer muitas coisas, semeando por intermédio do teatro idéias e reflexões sobre os objetos da cultura e a sociedade, daí a criação de um festival que reúna estudantes de várias idades.

Um Festival Estudantil agrega valores, fecunda, sem dúvida, um caminho que coloca a criança e o adolescente de frente com a essência da arte. Penso e acredito que sou o verdadeiro resultado de festivais de teatro e que, quando criança, pude entender e ajudar a me decidir como artista.

A reflexão parte dos seguintes questionamentos: qual é a identidade de um grupo estudantil que trafega por festivais de teatro? Em que aspecto pedagógico o Festival Estudantil pode contribuir? Qual a fusão entre o Festival Estudantil e o Núcleo de Artes Cênicas do Sesi Sorocaba-SP?

As alternativas de respostas serão investigadas por meio de referências obtidas nos escritos da história do teatro brasileiro, a partir de intelectuais, tais como: Sábato Magaldi, Clóvis Garcia, Ingrid Dormien Koudela, Maria Clara Machado, Sônia Azevedo e outros.

Dialogando com estes autores, encontro suporte teórico para justificar e entender melhor essa prática educacional, levantando questionamentos e princípios estéticos e filosóficos desse processo, que trafega pela eqüidade, pelo coletivo e pela diversidade cultural.

A pesquisa acadêmica não se limita a desenvolver um pensamento adquirido através de ações e de conhecimento em campo prático e/ou teórico, mas pretende também, por intermédio de sua narrativa, buscar outros caminhos para o teatro.

A maneira com que os grupos estudantis desenvolvem seus projetos é artesanal, pois começa aí o envolvimento com os funcionários da escola e com as pessoas da comunidade, é nessa relação que os pais também começam a atuar, sua colaboração, geralmente, é fundamental. Eles vão assumir os papéis de costureiros, cenógrafos, professores, produtores de arte e isso tudo vai possibilitando um estreitamento e certa familiaridade com a arte.

Em tempos atuais, o fazer e o assistir espetáculo teatral tem sido cada vez mais difícil e excludente, apesar das leis de fomento e apoio estabelecidas 
pelas Prefeituras, como também pelas instituições ligadas à indústria e ao comércio como o SESI, SESC e Secretarias de Cultura, não é obstante suficiente para o teatro chegar a alguns bairros e por que não dizer a algumas cidades do interior do estado.

É mister informar que não há material bibliográfico e pouquíssimo material videográfico sobre os Festivais realizados em nosso país, que ajudem a historiar todo processo. Até hoje, existem poucas investigações e documentações sobre $o$ assunto.

Este trabalho trata de uma aventura. A aventura entre o fazer teatro, o relato de experiências, a reflexão e os caminhos possíveis para valorizar esta linguagem artística que retrata e espelha as mazelas humanas.

O capítulo I vai abordar um panorama geral dos Festivais Estudantis no Brasil, no período compreendido entre 1933 a 2008. O seu nascimento, a sua importância e seus criadores e a influência que esses festivais tiveram no teatro brasileiro. Principalmente, o papel fundante do pernambucano Paschoal Carlos Magno e o seu pioneirismo. A criação e a participação dos Centros Populares de Cultura - CPC da União Nacional dos Estudantes - UNE. O nascimento do teatro feito por universitários que, mais do que preocupados com o espetáculo, preocupavam-se em levar ao público palavras de ordem, textos que acordavam a consciência político-social.

O capítulo II mostra o trabalho desenvolvido nos Núcleos de Artes Cênicas do Festival Estudantil do SESI de Sorocaba. Apresentaremos ainda o histórico dos Festivais Estudantis de Teatro e sua importância na formação de jovens no tocante às linguagens da encenação teatral.

Será mostrado o Festival que começou em 2002 e que teve importância como instrumento fecundador das artes cênicas entre os jovens estudantes. A ebulição que causou entre professores artistas, como também as dificuldades dos grupos envolvidos neste processo e sua trajetória até os dias de hoje. Com humildade, idealizado por mim, não é algo inovador, pois também me considero um resultado do processo de festivais estudantis. Por esse motivo, acredito ser de muito valia o estudo sobre essa passagem na história do teatro, deixando como colaboração aos que continuarão fazendo e participando dos festivais estudantis. 
No Capítulo III, apresentamos a pesquisa que fizemos com professores artistas responsáveis por incentivar e coordenar grupos de teatro de estudantes em suas respectivas escolas.

Os grupos se formam, na maioria das vezes, por interesses de alunos e ex- alunos que querem participar e em alguns casos por interesse dos próprios professores. Curiosamente, a escola pública é o lugar em que observamos uma freqüência maior de desenvolvimento desse trabalho, ainda que também tenhamos visto tal proposta em escolas particulares.

Percebe-se que a identidade dos grupos que participam dos festivais não difere muito uns dos outros de maneira geral. A cada ano, grupos já existentes crescem e grupos novos se formam, mas é natural o processo de seleção, até porque muitos dos estudantes não se adaptam às regras e aos padrões do trabalho, no tocante à horário, disciplina, constância, seriedade, enfim quesitos necessários ao bom funcionamento de qualquer trabalho em equipe.

O relato de cada um sobre o seu processo de trabalho, suas dificuldades, suas glórias etc... É um documento interessante até mesmo para a verificação das condições de trabalho de muitas escolas.

Acredito que ao percorrer a história dos Festivais Estudantis e realçar sua importância, defendo que o nosso tempo não se compadece com uma visão única de realidade. Mostrar o teatro como elemento propiciador de inclusão social, minimizando as contradições e reafirmando os propósitos de uma educação participativa, porque defendo um teatro comprometido com 0 homem no seu tempo e com os tempos do vir-a-ser. 


\section{Capítulo I}

\section{Festival Estudantil no Brasil}

Inicialmente, é necessário traçar o percurso da história do Festival Estudantil no Brasil para que se possa ter a real dimensão de sua importância e influência nos grupos teatrais que se formaram a partir de então.

Em 1933, foi iniciado um movimento que, futuramente, seria uma renovação para as artes cênicas de nosso país. Jovens atores amadores buscaram contatos com grêmios estudantis com o objetivo de fundar uma Casa do Estudante do Brasil em que houvesse o propósito de formar uma equipe amadora para contratar profissionais experientes e montar espetáculos teatrais.

Estão preocupados em alterar a forma de representação teatral e a maneira de ver do público. Não pensam ainda em modificar o recrutamento de público, fazem teatro para o mesmo público que é atingido pelo círculo da universidade. (DIONYSOS, 1980, p. 24)

O Teatro Estudantil ressurge com maior notoriedade em 1938, no Rio de Janeiro, com a fundação criada por Paschoal Carlos Magno com a ajuda de Renato Viana, do Teatro do Estudante do Brasil - TEB. Magno foi quem deu este primeiro passo, que iniciou com sua instituição da Casa do Estudante do Brasil com a montagem de Hamlet, de William Shakespeare. O novo conjunto lança um inusual padrão cênico e, juntamente, com Os Comediantes, conjunto amador criado no mesmo ano, forma a linha de frente da renovação cênica do país.

Já no ano de 1939, nasce o Teatro Acadêmico, iniciativa de Mário Brasini, absorvido, no ano seguinte, pelo Teatro Universitário - TU, sob a 
direção de Jerusa Camões e contando com o apoio logístico da recém fundada União Nacional dos Estudantes - UNE.

A presença da UNE cresce, em todo o Brasil, com a instalação do Governo de Juscelino Kubitschek, em 1955, adquirindo maior participação política e passando a albergar, entre seus dirigentes, representantes das diversas ideologias e trânsito no período. Esse movimento ideológico-cultural desemboca na criação do Centro Popular de Cultura da UNE - CPC, iniciado após as apresentações de "Eles não usam black-tie", pelo Teatro de Arena, no Rio de Janeiro. Ali, reunido com lideranças estudantis, Oduvaldo Vianna Filho ajuda a idealizar um movimento cultural prioritariamente destinado à mobilização da população, partindo da ação cultural com o objetivo de conscientizar as classes trabalhadoras. Inspirado no pernambucano Movimento de Cultura Popular - MCP, de Miguel Arraes, o CPC, multiplicado em inúmeros grupos espalhados pelo país, leva ao povo diversas manifestações artísticas cujo fim é usar formas da cultura popular para promover a revolução social em montagens que deveriam percorrer praças, ruas, portas de fábricas e sindicatos.

Após o golpe militar de 1964, com a UNE e os CPCs postos na ilegalidade, a política estudantil reflui para as instituições e vê-se surgir, nas principais universidades, grupos teatrais imbuídos do espírito cepecista ou contando, entre seus organizadores, com alguns de seus ex-integrantes.

Em 1958, Paschoal Carlos Magno organiza, em Recife/PE, o primeiro Festival Nacional, que passou a ser referência ao desenvolvimento da dramaturgia e laboratório de atores e diretores.

Os festivais organizados por Paschoal iniciavam suas atividades em 1959 e, em poucos anos, multiplicavam-se nas capitais e regiões em todo 0 país. Nos anos seguintes, além de promoverem ampla programação de espetáculos oriundos de todo país, estes festivais constituem-se, sobretudo, numa tomada de assalto das cidades em relação ao teatro. Inúmeras discussões, mesas-redondas, aulas, seminários, palestras e exposições. Essa ebulição cultural motiva o incremento de grupos estudantis ou universitários em muitas cidades brasileiras. 
A partir das iniciativas tanto de Paschoal Carlos Magno quanto das demais pessoas que contribuíram para este crescimento estudantil, escolas e entidades começaram a expor seus trabalhos e desejos, sem perder a dimensão do alicerce proposto inicialmente, criado em 1933. À medida que crescia, ingredientes a mais surgiam, trazendo elementos necessários para o crescimento de cada festival, de cada pessoa e de cada grupo.

\section{Teatro Universitário}

Dentre os movimentos amadoristas mais participativos na renovação teatral do Rio de Janeiro, o Teatro Universitário tem seu lugar destacado. Entende-se por teatro universitário, não propriamente uma categoria teatral, mas, sobretudo, um olhar inovador e menos convencional sobre a cena. Confundem-se, algumas vezes, com o teatro amador e com o teatro estudantil, nos seus sentidos amplos, fronteiras nem sempre nítidas entre essas manifestações que, todavia, apresentam um traço em comum: a recusa dos padrões convencionais da expressão teatral.

Desde o século XIX, o teatro estudantil mostra-se ativo e presente na cultura brasileira, verificável no movimento ocorrido na faculdade do Largo São Francisco, em São Paulo, por onde transitaram significativos nomes das letras nacionais.

Em 1958, novamente numa iniciativa de Paschoal, surge o primeiro Festival de Teatro, realizado no Recife/PE. Cidade que já conhecia desde 1946, o Teatro do Estudante de Pernambuco - TEP, o Teatro de Amadores de Pernambuco - TAP e o Teatro Popular do Nordeste - TPN, este impulsionado por Hermilo Borba Filho. Os festivais de Paschoal, em anos seguintes, além de promoverem ampla programação de espetáculos oriundos de todo o país constituem-se, sobretudo numa tomada de assalto das cidades em relação ao teatro.

Inúmeras discussões, mesas-redondas, aulas, palestras, seminários e exposições se encarregam de formar o público e despertar novos interessados, engrossando o movimento. Essa ebulição motiva o incremento de grupos 
estudantis ou universitários em muitas cidades brasileiras, bem como outros festivais, estaduais e regionais.

Em suas várias épocas, o teatro universitário representou, sempre, uma negação dos padrões artísticos vigentes - majoritariamente defendidos pelo profissionalismo - impondo uma renovação que pretendeu atingir não apenas os meios expressivos do palco como, de modo enfático, os padrões de gosto e de consumo da atividade teatral, ampliando consideravelmente os locais de oferta. Optando por um repertório que dificilmente um conjunto profissional ousaria montar, ofereceu ao espectador um grande leque de proposições artísticas. Do Hamlet, de Shakespeare de 1938, chega-se ao Brecht de 1968, paulatinamente vai percorrendo as etapas artísticas mais significativas da arte cênica ocidental.

O espetáculo de estréia, Filigranas, em 1938, apresenta trechos da Cavalaria Rusticana, da obra La Boème, de Rigolleto, arranjada por Jerusa Camões e Hugo Lacorte Vitale, intercalados com esquetes, poesias e números independentes. Após alguns espetáculos de êxito, o ministro Gustavo Capanema entrega-Ihes salas na sede da União Nacional dos Estudantes, UNE, e uma dotação do orçamento para a produção de peças determinadas, o que faz com que o grupo amador passe a ter que assumir responsabilidades de companhia profissional. Para cumprir a agenda, os estudantes ensaiam durante as noites e nas férias. Consta da temporada de 1943, A Viúva Alegre, de Franz Lehar; As Mulheres Nervosas, de Ernest Blum e Raul Touché, com direção geral de Jerusa Camões e direção artística de Mário Brasini; Dirceu e Marília, de Afonso Arinos de Mello Franco; Irmão das Almas, de Martins Pena; Cabecinha de Vento, de Silvio Zambaldi; O Carnaval, de J. Macedo Soares.

Esther Leão incumbe-se freqüentemente da direção, que tem participações também de Mário Brasini, Adacto Filho, Fernando Pamplona e outros. No elenco figuram atores estreantes como Nathália Timberg, Jaime Barcelos, Sérgio Cardoso, Sérgio Britto, Paulo Fortes, Fernando Torres - que no futuro farão carreiras no teatro.

São realizações do Teatro Universitário - TU, Romeu e Julieta, de William Shakespeare, 1945; Gonzaga ou A Revolução de Minas, de Castro Alves, 1947; A Dama da Madrugada, de Alejandro Casona, 1948; O Pai, de 
Strindberg, 1949; Quebranto, de Coelho Neto, 1950, todos sob a direção de Esther Leão.

O TU realiza seus espetáculos nos locais mais diversos, fazendo apresentações beneficentes, deslocam-se para outras cidades e representam em pátios, hospitais, escolas, quartéis, fábricas, onde quer que sejam chamados. O projeto da companhia transcende a produção teatral: o grupo, para conseguir recursos para as entidades estudantis, faz sociedade com um homem que possui brinquedos de parque de diversões e transforma uma praça em um parque, com apoio do Presidente da República, Getúlio Vargas, que autoriza sua instalação, por tempo indeterminado, em plena Praça do Russel, no Rio de Janeiro.

Jerusa Camões, atriz do grupo, faz um depoimento em que avalia sua contribuição para a história do teatro:

O TU tinha como proposta definida fazer teatro qualquer que fosse, como diversão, sem grandes revoluções cênicas. Coisas que nos alegrassem a vida. (...) No sentido de contribuir para essa alteração de mentalidades, acho que 0 nosso trabalho foi significativo. Por isso, costumo dizer que fomos necessários no nosso tempo. (...) Depois, o apoio ao estudante, naquele tempo, era coisa de se contar prosa. Era apoio mesmo. E confiança. Desde o governo até o crítico mais exigente estavam sempre dando apoio a nosso teatro. Nossos espetáculos faziam o maior sucesso. Nossas casas viviam superlotadas de gente. Pessoas das mais variadas posições sociais. (DIONYSOS - 1975, pág.29 e 30) 
Da fundação de São Paulo, no século XVI, nasce um teatro de caráter religioso. Usado para espalhar e reforçar a fé católica, o Teatro de José Anchieta foi um dos elementos que integraram o panorama da comunidade.

Depois das experiências teatrais ocorridas no período de formação da cidade, pouco se sabe sobre a existência de um teatro não-religioso que aqui tivesse tido lugar, como diz Elizabeth Azevedo (2000, p.31)

\begin{abstract}
Historicamente, os séculos XVII e XVIII, em São Paulo, refletiram exatamente os acontecimentos europeus ocorridos após a implantação do Cristianismo. O teatro fora para a civilização greco-romana impulso educacional e estético tão fundamental quanto dos tempos anchietanos. Aos poucos 0 espetáculo principal passou a ser a missa (...). Para que teatros se as basílicas eram os locais procurados? (Barro, 1976).
\end{abstract}

Antes do teatro estudantil houve, por parte da sociedade paulistana, um grande investimento no campo teatral, adaptaram prédios para apresentação de espetáculos e a formação de sociedades amadoras. Num período de cerca de 150 anos (1763-1870), surgiram cinco teatros em São Paulo. Foram eles: a Casa da Ópera (antiga), a Casa da Ópera (ou Teatro de São Paulo), o Teatro do Palácio, que passou a ser, mais tarde, o Teatro Harmonia Paulistana, o Teatro Batuíra e o Teatro São José. Segundo J. Galante de Souza, na primeira metade do século XIX, o Brasil já possuía 23 casas de espetáculo e que tal número mostra o "interesse do público" (1960:41). Na época, a cidade tinha somente dois locais de apresentação teatral: a segunda Casa da Ópera e o Teatro do Palácio dos Governadores.

A comemoração da independência, com a presença de D. Pedro, realizou-se nesse edifício. O proprietário do prédio, Joaquim José Freire da Silva, em 1824, por encontrar-se em sérias dificuldades financeiras, pediu por uma loteria que subvencionasse o teatro. 
O teatro desenvolve-se com o objetivo específico de atender às necessidades educacionais e, assim, naquela época, as três formas se uniam e se completavam: teatro/religião/educação.

Somente no século XIX que São Paulo ressurgiu como centro educacional (agora de ensino superior), e com ele o teatro.

Como afirma Azevedo

A maior parte do teatro acadêmico pode ser considerada como um teatro empenhado. Se seus enredos permanecem quase sempre no tradicional relato de encontros e desencontros amorosos, seu pano de fundo é essencialmente político e social; não político no sentido partidário do termo, mas no sentido da representação de conflitos que estavam latentes na sociedade brasileira. $O$ teatro deveria desempenhar uma função civilizatória. Deveria levar ao público os questionamentos e, se possível, a solução para os problemas brasileiros. (AZEVEDO, 2000, p.27)

O teatro dos estudantes de Direito levou muito a sério essa tal "missão civilizatória". Optou por deixar de lado o humor das peças convencionais e o romantismo característico dos romances, para tornar o palco um espaço de crítica, levando a dramaturgia como expressão e a escravidão e o passado brasileiro como temas, mostrando não apenas os problemas nacionais, mas também sugerindo suas soluções.

Todo esse processo surgiu com a inauguração da Faculdade de Direito do Largo de São Francisco. Dentre as mudanças ocorridas em decorrência da independência política do país, houve a necessidade de um grupo intelectualizado que cuidasse dos assuntos públicos. Não se podia mais depender dos brasileiros que se formavam nas universidades européias. Era preciso criar um staff brasileiro profissionalizado e autônomo. Foi então que surgiram as duas primeiras escolas de direito, formando o profissional considerado mais apto para tratar das questões públicas brasileiras. 
Quando a faculdade de Direito foi fundada, em 1828, o teatro estava fechado. Já em 1829, um grupo de estudantes arrendou o prédio por cinco anos. Da primeira sessão, que teve discursos e poesias bastante aplaudidas, os estudantes tomaram a iniciativa de escrever textos dramáticos. Formaram ainda sua própria companhia. No entanto, suas pretensões artísticas não duraram muito. $O$ ministro Clemente Pereira, neste mesmo ano, determinou que fossem proibidas a participação de estudantes em escolas públicas.

A única exceção era no período de férias. Com o passar do tempo, estendeu-se para as quartas-feiras e finais de semana, sendo encenado, dentre outros: Os Sete Infantes de Lara (de Pixérecourt e Mallefille), O pobre das ruínas, O meirinho e a pobre.

Os estudantes do Largo de São Francisco deixaram sua marca na vida da cidade. Vieram e ocuparam um lugar que se Ihes abria com a nova organização política do país.

Depois de um primeiro momento de grandes expectativas quanto ao futuro da Academia, foi necessário reorganizá-la para que ela cumprisse o papel que Ihe cabia na formação da intelligentsia brasileira. A cidade também se transformou e, depois de um estranhamento inicial, deixou-se levar pelo entusiasmo dos estudantes que povoaram suas ruas desertas.

Os acadêmicos conquistaram também os teatros da cidade, fazendo igualmente o papel de autor, platéia, ator e critica. Dos anos 1820 até cerca de 1870, foram a faculdade de Direito e seu corpo de estudantes que deram forma a vida e à cidade. Quando eles foram superados, o teatro de idéias e literário se enfraqueceu e praticamente desapareceu. (AZEVEDO, 2000, p 41) 


\section{Teatro do Estudante do Brasil - TEB}

Criado por Paschoal Carlos Magno, o Teatro do Estudante do Brasil TEB, tem seu ponto alto com a montagem de Hamlet, de William Shakespeare, em 1948, que coroa a iniciativa em prol da preparação técnica do ator e do teatro feito mais pelo amor que pelo dinheiro.

Inaugurado em 1938, o Teatro do Estudante do Brasil se dedica a montagens de grandes autores nacionais e estrangeiros - William Shakespeare, Gonçalves Dias, Sófocles, Henrik Ibsen, Martins Pena. O espetáculo de estréia, com direção de Itália Fausta, foi Romeu e Julieta, contando com a participação do corpo de baile do Teatro Municipal e da orquestra de cordas.

Em 1948, o TEB apresenta uma histórica montagem de Hamlet, dirigido por Hoffmann Harnisch, com uma composição realista do ator Sérgio Cardoso, a primeira de que se tem notícia no teatro brasileiro. Em 1951, realiza uma turnê de dois meses e meio pelo norte do país representando, tanto em salas fechadas quanto em espaços abertos, um repertório de cerca de sete espetáculos, gratuitamente. Trata-se de um trabalho de formação de atores e público, como também, da disseminação de uma dramaturgia diferenciada, com montagens de Édipo Rei e Antígone, de Sófocles; Hécuba, de Eurípedes; Romeu e Julieta, de William Shakespeare; Os Espectros, de Henrik Ibsen; Autos, de Gil Vicente, e O Noviço, de Martins Pena, tendo Esther Leão como ensaiadora na excursão.

A realização de maior vulto do TEB é a formação de elencos para a apresentação de espetáculos em lugares públicos da cidade. Em 1953, Paschoal Carlos Magno consegue 15 caminhões e os transforma em verdadeiros teatros ambulantes, realizando 500 apresentações.

Paschoal Carlos Magno escreve sobre a criação do TEB:

O Teatro do Estudante nasceu de minha total loucura. Eu tinha chegado da Europa e via aqui a situação melancólica do teatro brasileiro, um teatro sem muita orientação técnica, representado 
por atores e atrizes sem a menor preparação. Digo melancólico, porque havia uma crescente ausência de público e um número cada vez maior de companhias que multiplicavam seus frágeis esforços, suas energias, sem encontrar eco por parte da platéia e da imprensa. (...) percebendo que nada se pode fazer nesse país sem o apoio dos estudantes, apesar da má vontade de algumas autoridades de ontem, de hoje e de sempre, percebendo que nada se pode fazer aqui sem a participação dos moços, (...) reuni, na casa de minha mãe, dezenas de jovens planejando criar o TEB". (DIONYSOS, 1975, p3)

É inegável a importância de Paschoal Carlos Magno como alguém que nunca deixou de valorizar a improvisação inerente à atividade amadora. Exerceu influência mais pelo entusiasmo do que pela preocupação com os aspectos artesanais da arte de representar, além de ter sido grande responsável pela expansão, inclusive geográfica, dos festivais em todo o território brasileiro.

No entanto, é notória a frustração com a falta de incentivo do governo à cultura, observada em suas palavras publicadas no jornal Correio da Manhã de 23/06/1949

(...) Não há desencantos no meu gesto. Há cansaço, muito cansaço e uma certeza de que se poderia fazer grandes coisas neste país se houvesse menos banquetes oficiais; se os homens não interessassem, em vez das idéias que defendem; se a cultura encontrasse, junto das autoridades o clima que só os prélios esportivos alcançam; se não existisse a permanente preocupação de diminuir os que lutam pela educação do povo, obrigando-os à humilhante perda de tempo, na antecâmara dos importantes do governo e da fortuna. E uma melancolia imensa de saber que não fui útil como desejei ardentemente. Esta despedida é a confissão da qual não me envergonho: de haver fracassado. (DIONYSOS, 1975, p.174) 


\section{Teatro Duse}

Criado por Paschoal Carlos Magno, o Teatro Duse abriga o TEB, que lidera o movimento em favor da formação de profissionais e do teatro comprometido com a arte mais do que com o lucro.

Quando Paschoal Carlos Magno transforma 0 andar térreo de sua residência em um teatro, o TEB já conta com mais de dez anos de atividade. Inaugurado em 1938, o TEB se dedica a montagens de grandes autores nacionais e estrangeiros - William Shakespeare, Gonçalves Dias, Sófocles, Henrik Ibsen, Martins Pena. Em 1952, o TEB realiza uma turnê de dois meses e meio pelo norte do país apresentando, gratuitamente, um repertório de sete espetáculos. Na volta, o TEB inaugura o Teatro Duse, de cem lugares, sobre o qual escreve seu idealizador:

Todos os elementos que o servem no Teatro Duse - bilheteiro, porteiro, indicadores, intérpretes, cenógrafos, figurinistas, maquinistas, publicistas, costureiras, aderecistas, secretários, diretores - são estudantes. Não anima o Teatro Duse nenhum objetivo comercial. É o núcleo de um teatro-escola, dirigido por moços e baseado no entusiasmo, no desinteresse e no idealismo dos moços.

Durante seus quatro anos de existência, o Teatro Duse apresenta 21 autores brasileiros inéditos, entre eles Frankel, de Antônio Callado; Lampião, de Rachel de Queiroz; João Sem Terra, de Hermilo Borba Filho; e Lázaro, de Francisco Pereira da Silva. Além de realizar montagens, o Teatro Duse dedicase ao ensino da profissão que, em cursos de um ano de duração, inclui o estudo da prosódia, da história do teatro, da caracterização, da mímica, do texto. Esther Leão é a professora encarregada de ensinar aos alunos a arte de interpretar. Entre os demais professores, figuram: Bibi Ferreira, Nina Ranewsky, Adacto Filho, José Jansen. Participam do TEB, entre outros Othon Bastos, B. de Paiva, Fernando Pamplona, Oswaldo Loureiro, Maria Pompeu, Consuelo Leandro, Pernambuco de Oliveira, Glauce Rocha, Miriam Pérsia e Joel Barcelos. 
O Teatro Duse abre-se a outros grupos amadores que se apresentam em sua sala de espetáculos. Faz também produções conjuntas, em que reúne profissionais convidados a alunos do TEB. Nessas ocasiões, dá preferência a autores estrangeiros e textos ainda inéditos no Brasil, como Espectros, de Henrik Ibsen, e peças de Anton Tchekhov em um ato.

Em 1956, o Teatro Duse encerra suas atividades. Em abril de 1958, com o patrocínio da Sociedade Brasileira de Arte, reabre, com direção de Paschoal e com Luís de Lima como professor e diretor de espetáculos, mas volta a fechar depois de quatro meses, tendo produzido um espetáculo, que se apresenta no Primeiro Festival Nacional de Teatro de Estudantes, em Recife/PE.

O Teatro do Estudante e o Teatro Duse iniciam um movimento que vincula o aprendizado do teatro à escola e, por meio da atuação de amadores, renova o teatro brasileiro nas décadas de 1940 e 1950, cultivando a idéia do estudo e da técnica em substituição ao improviso e ao talento nato. São precursores de outras iniciativas como a Fundação Brasileira de Teatro, FBT, da atriz Dulcina de Morais; O Tablado, da dramaturga e diretora Maria Clara Machado, e das escolas de teatro que nessa década começam a surgir no país.

Ali se instituiu a figura do diretor, extinguiu o ponto (em que os atores ouviam as falas em caso de esquecimento) e valorizou-se a equipe de cenógrafos e figurinistas. Com essa iniciativa alcança enorme sucesso e prestígio.

O Duse que, na verdade, era o porão da casa de Paschoal, em Santa Teresa, recebeu esse nome em homenagem a atriz italiana Eleonora Duse. O teatro funcionou, com ingresso gratuito, até 1956, revelando, entre outros, Aristóteles Soares, Francisco Pereira da Silva, Leo Vitor, Antônio Callado, Rachel de Queiroz, entre outros, conquistando um lugar de prestígio no panorama cultural do Rio de Janeiro.

Nomeado responsável pelo setor cultural e universitário da presidência da república por Juscelino Kubistchek, desloca-se permanentemente pelo país afora, garimpando jovens talentos e lutando pela criação ou dinamização de 
espaços onde eles possam dar vazão à sua ânsia de aprender e criar. O Teatro Duse abriga o TEB, que lidera o movimento em favor da formação de profissionais e do teatro comprometido com a arte mais do que com o lucro. Quando Paschoal transforma o andar térreo de sua residência em um teatro, o $T E B$, já conta com mais de dez anos de atividade.

O Teatro do Estudante e o Teatro Duse iniciam um movimento que vincula o aprendizado do teatro à escola e, por meio da atuação de amadores, renova o teatro brasileiro nas décadas de 1940 e 1950, cultivando a idéia do estudo e da técnica em substituição ao improviso e ao talento nato.

Quando a Fundação Nacional de Artes Cênicas comprou a casa de Paschoal, o Teatro Duse passou a fazer parte da rede de teatros da instituição, sendo reaberto em 02 de agosto de 1998.

\section{TUCA}

Grupo teatral universitário da Pontifícia Universidade Católica de São Paulo que torna internacionalmente conhecida a montagem de Morte e Vida Severina, de João Cabral de Melo Neto, em 1965.

Em 1963, o Diretório Central de Estudantes da Pontifícia Universidade Católica de São Paulo, DCE/PUCSP, resolve montar um grupo teatral, inspirado nas propostas do Centro Popular de Cultura, CPC. A iniciativa traz um problema prático: onde ensaiar? $\mathrm{O}$ auditório da universidade está sendo ultimado, e os estudantes forçam a direção da instituição a liberar seu uso. Com a criação de um Departamento Cultural, são contratados alguns profissionais: Roberto Freire, para a direção geral do grupo teatral; Silnei Siqueira, para coordenar a formação dos atores e José Antônio Ferrara para a cenografia.

No mesmo período, outras universidades propõem e obtêm o apoio de Nagib Elchmer, presidente da Comissão Estadual de Teatro, para uma dotação de verba destinada ao fomento de grupos de teatro universitário. O auxílio contempla o TUCA; o Teatro do Mackenzie, TEMA; o Teatro Sedes Sapientiae, TESE e o Teatro dos Universitários de São Paulo, TUSP. 
Em abril de 1965, iniciam-se as convocações para o elenco. Após algumas hesitações, Morte e Vida Severina, auto de natal pernambucano, de João Cabral de Melo Neto, é escolhido, preenchendo as expectativas estéticas e de atuação política da equipe. Uma pré-estréia evidencia a quase total falta de recursos técnicos e de produção. Sandro Polloni, dono do Teatro Maria Della Costa, TMDC, encantado com o que vê, empresta o equipamento de luz e assina a iluminação cênica. A montagem é aberta ao público, no dia 11, causando impacto na platéia e na crítica.

A falta de recursos e o grande número de intérpretes conduzem o diretor Silnei Siqueira a um espetáculo despojado, pleno de marcações estilizadas, usando os atores como suportes. A cena da mulher da janela torna-se famosa: dois atores, com os braços fazem os vãos e paredes; deslocamentos com os braços imitam o canavial embalado pelo vento; romarias circulares preenchem o grande espaço do palco vazio. A música de Chico Buarque de Hollanda, composta de melodias adequadas a um coro sem muitos recursos vocais, revela-se um trunfo. A beleza do texto bem pronunciado, alternando entre a crueza da vida miserável e o júbilo pelo nascimento de uma criança, atribui à montagem um tom cortante, severo, mas lírico.

O sucesso da empreitada conduz o TUCA ao Festival de Teatro Universitário de Nancy, França, onde obtém o primeiro lugar. Tal consagração faz a temporada prolongar-se no Théatre des Nations, em Paris, e outros países europeus, por 50 dias. O poeta João Cabral de Melo Neto, até então conhecido apenas entre as elites intelectuais, amplia seus horizontes de divulgação da obra.

Uma sugestão do Festival, para o ano seguinte, é encampada pelo TUCA: realizar um espetáculo que gire em torno da morte de um estudante que se descobre mais tarde, ser o filho de um rico industrial do país.

A radicalização da Censura em 1968, as perseguições policiais sobre o elenco e o crescimento do movimento estudantil que luta contra a ditadura, impõem a desagregação do TUCA. Ele ressurge em 1969 sob a direção de Mário Piacentini e com novos propósitos. A montagem de Comala, baseada em romance de Juan Rulfo, estréia de modo discreto e, fora do Brasil, visita o Festival de Manizales, na Colômbia. Uma versão modificada, denominada 
Terceiro Demônio, marca a saída da equipe da PUCSP, em 1970, transferida para as instalações de um cursinho. Existe, ainda, com uma parte desse conjunto, outra versão de Terceiro Demônio, agora independente e desvinculada da universidade, em 1972.

\section{Teatro Popular do SESI - TPS}

Grupo teatral ligado à associação de industriários que cria expressivo movimento de popularização da atividade teatral desde a década de 1960 .

O Serviço Social da Indústria - SESI existe desde 1945 e, a partir de 1948, passa a incentivar a prática teatral dentro das indústrias. Contrata, para tanto, ensaiadores incumbidos de formar elencos e montar espetáculos com grupos operários. Osmar Rodrigues Cruz é contratado em 1951, passando a dirigir um desses grupos na empresa Rhodia, em Santo André.

O Teatro Experimental do Sesi era composto por um elenco de caráter amador e o sucesso de suas produções levaram a diretoria da instituição a considerar a possibilidade de dar ao elenco e à iniciativa garantias mais constantes, profissionalizando-o.

Sua bem sucedida experiência leva-o a expandir as atividades e propor uma consolidação do serviço. Seguindo as idéias de Jean Villar, grande promotor do teatro popular francês que visita São Paulo, em 1957, propõe um plano de unificação dos esforços isolados e a criação de um elenco estável, montando espetáculos voltados ao gosto e às necessidades culturais dos operários. Nasce assim, em 1959, o Teatro Experimental do Sesi, fase inaugural do projeto. A Torre em Concurso, de Joaquim Manuel de Macedo, sob a direção de Osmar, é sua primeira produção. Seguem-se outras incursões até que, em 1963, a direção do Sesi, convencida do sucesso da iniciativa, acolhe o elenco formado e a ele atribui outro status, configurando o Teatro 
Popular do Sesi, TPS, a partir das duas diretrizes básicas previstas no plano de Osmar: ingresso gratuito e elevado teor artístico nas realizações.

Nesse renovado formato ocorre a estréia de Cidade Assassinada, de Antônio Callado, em 1963, dedicado a fazer teatro gratuito não apenas na capital, mas também nas cidades do interior. Muitas delas recebendo, pela primeira vez, um conjunto profissional de qualidade.

Noites Brancas, de Dostoievski, em adaptação de Bertha Zemmel, prossegue a programação, em 1964. Ainda sem sede fixa, o conjunto ocupa salas de teatro disponíveis, procurando um repertório que se adapte aos propósitos do empreendimento. Manhãs de Sol, de Oduvaldo Vianna, 1966, constitui-se num êxito, apenas superado por O Milagre de Annie Sullivan, de William Gibson, no ano seguinte, centrado na luta da professora Ellen Keller para ensinar uma indisciplinada menina cega. A montagem lota, durante dois anos consecutivos, a sala do Teatro da Associação Israelita Brasileiro - TAIB. Outro grande sucesso é Senhora, de José de Alencar, adaptado para a cena por Sérgio Viotti, em 1971.

Uma nova fase inicia-se em 1977, com a construção da sala permanente do conjunto, no prédio da Federação das Indústrias do Estado de São Paulo FIESP, na Avenida Paulista, e o ciclo de grandes produções e musicais. Inaugura a série O Poeta da Vila e Seus Amores, de Plínio Marcos, sobre a vida e a obra de Noel Rosa, em 1977; além de Chiquinha Gonzaga, Ó Abre Alas, de Maria Adelaide Amaral, 1983; e O Rei do Riso, de Luís Alberto de Abreu, 1985.

Entre as produções dramáticas, ganham destaque $A$ Falecida, de Nélson Rodrigues, em 1979; com cenografia e figurinos de Flávio Império, em excelentes criações. Muito Barulho Por Nada, de William Shakespeare, 1986; Feitiço, de Oduvaldo Vianna, 1987; Onde Canta o Sabiá, de Gastão Tojeiro, 1988, e Confusão na Cidade, de Carlo Goldoni, 1989, uma seqüência de encenações dirigidas por Osmar Rodrigues Cruz.

Com a aposentadoria de Osmar, seu grande impulsionador, o TPS, conclui um ciclo de serviços prestados à comunidade operária paulistana. Após sua saída, novos rumos são traçados para a sala: a dissolução do 
conjunto fixo, a contratação de elencos e diretores específicos para produções avulsas. Numa primeira fase, a partir de 1994, são criados grandes espetáculos, sob a batuta de jovens encenadores, como Antônio Abujamra, Bia Lessa, Ulysses Cruz, Gabriel Villela e Moacyr Góes. A partir de 1996, o Sesi passa a contratar montagens já realizadas e consagradas junto à crítica em suas temporadas comerciais, organizando uma programação de jornadas. Implanta, também, um esquema de terceirização de produções de médio porte, voltando a estrear produções na casa, com a participação de dramaturgos e encenadores consagrados.

\section{Festival Estudantil de Teatro do Estado de São Paulo}

Pode-se definir o Festival como o encontro de apaixonados pelo teatro amador. Assim é o Festival Estudantil de Teatro do Estado de São Paulo, oficializado por meio do decreto estadual 18.434/82. O Festival, realizado anualmente sempre no segundo semestre, é a oportunidade de jovens estudantes mostrarem os resultados de estudos e experiências teatrais.

Em Tatuí, grupos de teatro infantil e adulto, formado por estudantes do Ensino Fundamental e Ensino Médio, têm estimulado o gosto pelas artes cênicas. Além da oportunidade de mostrar ao público seus espetáculos, os jovens atores participam de oficinas e workshops de aprimoramento.

Em 2005, na cidade de São Paulo, a subprefeitura do Ipiranga deu início ao $1^{\circ}$ Festival Estudantil de Teatro, dirigido às escolas públicas e privadas do Ensino Fundamental dos distritos de Ipiranga, Cursino e Sacomã. Os participantes puderam participar do projeto de leitura de clássicos da dramaturgia brasileira e universal. Os ganhadores do festival foram premiados com ingressos para peças teatrais na cidade de São Paulo, por meio do Departamento de Teatros da Secretaria Municipal de Cultura. O festival ocorreu no mês de novembro, nas dependências da Casa da Cultura. 


\section{A importância do Festival Estudantil no estado de São Paulo}

São várias cidades e estados que atuam com o intuito de trabalhar com os estudantes de nosso país, estimulando o interesse pelas artes cênicas, promovendo intercâmbio cultural, além de incentivar os movimentos teatrais por meio da formação de núcleos teatrais nas instituições de ensino e recreação.

Com a finalidade de incentivar o fazer artístico nas escolas, buscando a integração entre as atividades educacionais e as diferentes formas de expressão, é realizado em cada canto de nosso país o Festival Estudantil que é um olhar inovador e menos convencional sobre a cena.

No Festival Estudantil, as escolas públicas, particulares e entidades assistenciais montam os seus espetáculos, sendo que cada uma dessas entidades é responsável pela direção, montagem, texto, figurino, cenário etc.

Esses conjuntos arregimentam muitos jovens, abrem espaço para o surgimento de novos talentos e idéias nas artes cênicas; estimula a formação de grupos teatrais dentro e fora das escolas; estimula o gosto do público pelas artes cênicas, levando às casas de teatro, consumidores habituais e não habituais de cultura; democratiza o acesso à produção, aos bens, produtos e serviços culturais; organiza palestras e debates que tratem de temas polêmicos, pertinentes e atuais no teatro, a fim de promover uma qualificação dos participantes e do público em geral, e uma interação entre eles, problematizando para criar soluções e idéias; estimula a produção artística entre os estudantes, independente do seu grau de escolaridade ou condição social, promovendo uma interação entre eles e proporcionando e/ou aprimorando os conhecimentos práticos e teóricos dos participantes.

Paschoal Carlos Magno (1906-1980) ${ }^{1}$ idealizou o $1{ }^{\circ} \mathrm{Festival}$ de Teatro de Estudantes do Brasil, que foi um sucesso em todo o país, tendo até mesmo 31 Nasceu no Rio de Janeiro. Poeta, romancista, diplomata de carreira, vereador pelo Distrito
Federal, chefe de gabinete no Governo de Juscelino Kubistchek, mas acima de tudo,
homem de teatro. Começou no teatro junto com Renato Vianna, na Caverna Mágica.
Depois, esteve com Álvaro Moreyra na segunda temporada do Teatro de Brinquedo, foi
Diretor artístico da Companhia Jayme Costa e, em 1938, fundou o Teatro do Estudante do
Brasil - TEB. Foram inúmeras as suas contribuições para o desenvolvimento do moderno 
o apoio do Presidente da República, Dr. Juscelino Kubitschek, festival esse que ocorreu em Recife em 1958 e uniu mais de 1.400 estudantes de todo o país. O sucesso do festival foi tanto que Paschoal não parou por aí e levou esse festival até sua $6^{\mathfrak{a}}$ edição em 1971.

Com o TEB, realizou viagens pelo país, a exemplo das "missões dramáticas" de Renato Vianna. Em 1952, criou em sua casa, em Santa Teresa, - Teatro Duse, destinado a encenar novos autores. O Teatro Duse passou a ser importante referência ao desenvolvimento não só da dramaturgia, também laboratório de atores e diretores. Programou festivais de teatro por todo o país. Fundou a Aldeia de Arcozelo. A ação mais extraordinária de Paschoal Carlos Magno foi no sentido de estimular o amor ao teatro nos jovens, apoiando aqueles que ao teatro se dedicassem.

Homem à frente de seu tempo, Paschoal Carlos Magno redimensionou a cena da época e botou o Brasil no palco.

Renato Vianna ${ }^{2}$ inicia a carreira como dramaturgo, escrevendo para a atriz Itália Fausta. Une-se aos modernistas, o maestro Villa-Lobos e o poeta Ronald Carvalho, com os quais funda a Sociedade dos Companheiros da Quimera, com o objetivo de elevar o nível cultural e intelectual do teatro, em 1922. No mesmo ano, escreve e dirige A Última Encarnação de Fausto, interpretando Mefistófeles, e anuncia a estréia dizendo que se trata do primeiro teatro de encenação do Brasil. Pouco teatral e de reflexões verborrágicas, o espetáculo, embora traga um novo uso da luz, do som e da cenografia, é duramente criticado.

Na década de 1940, o autor viaja para Porto Alegre, onde funda a Escola Dramática do Rio Grande do Sul e o Teatro Anchieta, onde realiza montagens de alunos. Em 1946, cria o Teatro do Povo, iniciativa pioneira de

teatro brasileiro. Do Curso de Férias de Teatro, que organizou em 1944, por exemplo, se originou o Teatro Experimental do Negro.

${ }^{2}$ Autor, diretor, ator. Autor do único espetáculo que, no ano em que nasce o Modernismo no Brasil, procura criar uma estética nova. Renato Viana tem em sua carreira uma série de iniciativas voltadas para a transformação da cena e do processo de produção teatral 
fazer teatro com e para operários. Volta duas vezes ao Rio de Janeiro para apresentar espetáculos. Em 1948, é convidado a dirigir a Escola de Teatro Martins Pena, do município do Rio de Janeiro.

Sem se firmar no panorama do teatro brasileiro nem como autor, nem como diretor, Renato Viana traz, dos espetáculos que assiste no exterior, idéias que ele passa toda a sua vida procurando difundir e praticar por meio de projetos pedagógicos e de circulação de espetáculos. Ainda que não se materializem em suas montagens, essas idéias resumem os princípios do teatro moderno, que entram na ordem do dia a partir do trabalho de grupos amadores como o TEB e Os Comediantes.

O espetáculo do TEB, companhia amadora dirigida por Paschoal Carlos Magno, marca a história do teatro brasileiro pela interpretação de Sérgio Cardoso no papel - título, ator que retorna ao texto também como encenador, oito anos depois, na montagem de abertura de sua própria companhia, em parceria com Nydia Licia.

Iniciativa arrojada, a de Paschoal Carlos Magno, ao promover a segunda representação brasileira da imortal tragédia de Shakespeare. Desde João Caetano, no século passado, jamais a circunstância se repetira com elenco um nacional. Tão pouco por famosos atores estrangeiros como Zaconni, Novelli, Brazão, Rugiere e outros, ou ainda, recentemente, na figuração de Bem Ami. Contudo, devemos inicialmente registrar que a tarefa de Carlos Magno foi coroada de brilhante êxito. $\mathrm{Na}$ atual fase do teatro brasileiro, é preciso mesmo um pouco de audácia, algo capaz de agitar a formação de novos elementos. $\mathrm{E}$ a idéia básica do Teatro do Estudante foi vitoriosa, porquanto, além de revelar um autêntico talento para a nossa ribalta - Sergio Cardoso - apontou algumas outras figuras promissoras.

A trajetória do $T E B$, em sua continuidade e proposta artística, colabora para a transformação do panorama teatral, que vê aos poucos surgir diversos conjuntos de amadores e estudantes voltados a um repertório de grandes obras dramáticas e à técnica de interpretação. A encenação de Hamlet, com direção de Hoffmann Harnisch, parte do estudo do texto e procura tornar claros seus meandros. Em artigo para $O$ Jornal, o cenógrafo Tomás Santa Rosa considera que, se nem sempre a realização dos jovens do TEB é profunda, 
sempre é intensa e viva. Segundo ele, "se a quase totalidade dos atores, pela inexperiência (...) não consegue sair da vasta planície amadorista, consegue, porém pela disciplina nos reconstituir o drama, sem prejudicá-lo em suas grandiosas linhas". ${ }^{3}$

Para o público e a crítica da época, tal realização já seria, por si só, suficiente para conferir méritos à iniciativa de encenar uma das maiores obras da dramaturgia universal. Mas o que causa impacto e admiração na platéia é a interpretação inovadora de Sérgio Cardoso, calcada no estudo e na construção da personagem em uma época em que entre os atores predominava a crença no talento nato. Tomás Santa Rosa observa que "no palco, a sua própria figura franzina cede ao brilho do seu jogo" e detalha mais ainda o seu desempenho:

"Sérgio Cardoso, no entanto, se distancia de seus colegas, urdindo todo o desenrolar dos incidentes, compensando, mesmo aqueles pontos fracos ou neutros, com a sua vibratilidade e inteligência. Sente-se a construção intelectual da personagem passo a passo, talvez o mais complexo personagem da história dramática. (...) A sala toda estava unida nessa tensão pela criação do autêntico. O célebre monólogo "ser ou não ser", desenvolvido numa linha de mestre, lembrou-me por associação as entonações de Maurice Evans. Isso prova o carinho dispensado à composição do seu magnífico papel, lendo, ouvindo e estudando (...). Assim, pode penetrar as nuanças do caráter indeciso do Príncipe da Dinamarca e interpretar-Ihe as dúvidas e as incongruentes mudanças". 4

Sérgio Cardoso, exercendo a dupla função de encenador e ator, investe novamente sobre o texto de Hamlet, em 1956, para inaugurar sua companhia paulistana ao lado de Nydia Licia. Sua leitura do original, agora, reflete seu crescimento como intérprete e ser humano, propiciando uma realização mais madura do que aquela do TEB. Apoiado sobre cenários e figurinos de Eduardo Suhr - uma sólida construção figurando o palácio, com duas torres laterais permitindo as mudanças de cena - a montagem busca o proscênio e a aproximação com o público como recursos privilegiados para a ação.

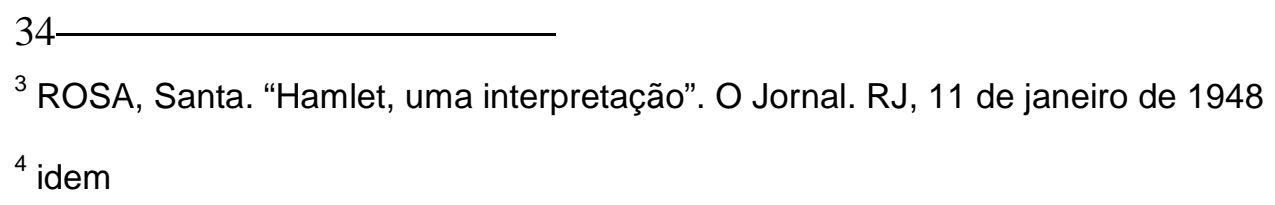


A tradução utilizada é a de Péricles Eugênio da Silva Ramos que, embora próxima do original, mostra-se pesada à articulação vocal e impõe um ritmo lento, nem sempre compreendido pelos ouvidos da platéia. O elenco, quase todo com menos de 25 anos, igualmente contribui para desestabilizar o conjunto das interpretações. Destaca-se, contudo, a iluminada criação do próprio Sérgio, saudada como sóbria, pensada, tornada mais segura e mordaz desde sua estréia carioca.

A atriz Nydia Licia vive a rainha Gertrudes, em composição natural e discreta; Bertha Zemel dá vida à Ofélia, notável na cena da loucura; Jorge Fisher Júnior, como Laerte, Carlos Zara como Cláudio e Emanuel Corinaldi como Polônio, lutam não apenas contra as próprias idades como também a inconstância vocal, dificultando o entendimento de muitas frases.

Na ocasião de Chá e Simpatia, em 1957, com a companhia já plenamente estabelecida, o crítico Décio de Almeida Prado escreve:

Não há nada mais emocionante do que assistir ao nascimento e ao gradual florescimento de uma jovem companhia. (...) Passado somente um ano, a estréia de Chá e Simpatia vem demonstrar, amplamente, que a companhia de Sergio Cardoso alcançou por fim a sua maioridade: é agora um conjunto profissional como os que melhor o sejam. Esta evolução reflete-se, aliás, com impressionante fidelidade, no amadurecimento dos dois primeiros atores, responsáveis pelo conjunto: Nydia Licia e Sergio Cardoso. (...) (Ela) ...foi afinando as suas qualidades de doçura, de dignidade, de delicadeza, até vencer pela sensibilidade uma certa frieza interior, colhendo numa peça como esta, que pedia exatamente aqueles requisitos, o seu maior triunfo, firmando-se como uma das primeiras atrizes do nosso teatro. Com referência a Sergio o amadurecimento foi de outra ordem: não como ator, porque já era um intérprete de exceção, mas como encenador e chefe de companhia. (PRADO, 1964. P.55) 
Entre tantos acertos e dificuldades apontadas, esta encenação de Hamlet alcança, contudo, largo reconhecimento entre o público e a crítica especializada. Sobre ela manifesta-se Décio de Almeida Prado: "A maior virtude do espetáculo, indo de um pólo a outro, é certamente a direção e a interpretação individual de Sérgio Cardoso, ambas excepcionais. O seu primeiro Hamlet, há oito anos, tinha um máximo de permanente vibração emocional para um mínimo de análise do texto. Ficava-se arrepiado - mas não se sabia bem por que. A compreensão, a lucidez intelectual, ao contrário, é a própria marca deste seu segundo Hamlet, como prova de que todos estes anos não se passaram em vão".

Espetáculo de lançamento do TEB, conjunto organizado, dirigido e mantido por Paschoal Carlos Magno. A montagem de 1938, antecipa em vários procedimentos 0 advento da encenação moderna no Brasil. 54 anos depois, dirigido por Gabriel Villela, com o Grupo Galpão, a montagem recontextualiza a grande história de amor para o universo da cultura popular brasileira, sendo ao mesmo tempo fiel ao espírito shakespeariano.

Com direção de Itália Fausta, o espetáculo revela os jovens atores Sônia Oiticica, no papel de Julieta; Paulo Porto, como Romeu; Antônio de Pádua, como Mercúrio; e Elvira Fonseca, como a Ama. A realização prima por um alto nível no acabamento do espetáculo. A imprensa aplaude a iniciativa. Mário Nunes escreve:

O belo sonho de Paschoal Carlos Magno teve ontem, à noite, uma esplêndida realização. Estudantes das nossas escolas superiores interpretaram Romeu e Julieta, de William Shakespeare, na bela versão portuguesa do Dr. Domingos Ramos. Foi um espetáculo de arte a que Itália Fausta sem outro estímulo do que a satisfação do seu ideal de teatro emprestou como ensaiadora sua valiosa colaboração. Um público seleto aplaudiu com entusiasmo e espontaneidade todos os quadros (...). (DIONYSOS, 1975, p133)

Antônio de Pádua (o Mercúrio de Romeu e Julieta) ainda diz: 
"Espantaram-se muito com a escolha que o Teatro do Estudante fizera para a peça de estréia. "Romeu e Julieta", o grande idílio shakespeariano, era uma escolha audaciosa. Alvitraram alguns que se devia ter começado por algum clássico francês: Corneille ou Molière. Os que assim pensavam, crendo Corneille de mais fácil interpretação, erraram. Grande diferença existe entre o teatro Shakespeare ano e o Corneliano. Este será apenas o teatro declamatório, artificial; aquele, apesar de mais velho, é mais real, mais humano, e, por isso de representação menos difícil". (DIONYSOS, 1975, p125)

Sobre a protagonista, o crítico do Jornal do Brasil, prevendo seu êxito em carreira futura, analisa:

Sônia Oiticica, deveras encantadora, possui uma voz cheia de sonoridades graves, de uma tonalidade apaixonada, portanto, e, em alto grau, o dom da intuição. Representou com grande naturalidade e com calor logo que o drama se desencadeou e foi de uma celeste suavidade em toda a fase idílica. (DIONYSOS, 1975, p133)

Também com relação ao espetáculo o crítico mostra entusiasmo:

"A encenação à época merece elogios pelos detalhes a que desceu. O corpo de baile do Municipal deu às danças do primeiro ato um alto senso de elegância coreográfica, sendo aplaudido com calor, e assim a orquestra de cordas, que sob direção do maestro T. Chiafitelli foi de uma suavidade e doçura verdadeiramente celestiais". (DIONYSOS, 1975, p134)

Num artigo escrito sobre as origens e descobertas do Teatro Brasileiro, no século XX, a pesquisadora Tânia Brandão analisa as características pré- 
modernas presentes na montagem do $T E B$, implementadas pela diretora Itália Fausta que observou que a montagem trazia em seu bojo uma inquietude reivindicatória própria daqueles jovens artistas, como Eugênia e Álvaro Moreyra, Oswald de Andrade e outros jovens preocupados em buscar um inteiramente novo.

Sem dúvida foi esta condição que fez com que Paschoal Carlos Magno a convidasse para dirigir o TEB, empreendimento com que ele pretendeu propor uma mudança decisiva da cena nacional. A atriz foi a diretora da peça de estréia do grupo, Romeu e Julieta, de Shakespeare, em 1938, uma proposta que evidenciava algumas das condições que os novos julgavam que era necessário mudar. No seu entender, era preciso oferecer outros autores e formar outros atores; elevar o repertório e revolucionar a interpretação, abolindo o ponto, as convenções e hierarquias; voltar a encenar Shakespeare, ausente dos palcos daqui desde João Caetano, muito embora o autor tenha encenado a versão de Otelo de Ducis". (MICHALSKI, 1989)

Em 1992, após uma série de outras remontagens não muito representativas, a peça Romeu e Julieta ressurge, numa parceria iluminada entre o diretor Gabriel Villela com o Grupo Galpão, de Minas Gerais. O grupo se dedica durante seis meses aos ensaios, com aulas de esgrima, aeróbica, voz e técnicas circenses que já são do domínio dos atores. O espetáculo mistura o circo, o cancioneiro popular mineiro e as técnicas de teatro de rua. Os figurinos são cobertos de cal colorida.

O elemento principal da cenografia é uma perua Veraneio, colocada de lado para a platéia, sobre a qual se monta um palco fragmentado em três áreas de diferentes planos, da qual se entra e sai pelas portas, usando-a como coxia, ou abrindo a janela para mostrar apenas o rosto. Os instrumentos são enfeitados com decalques floridos, e o cenário é adereçado com vasos de flores artificiais, tudo feito à mão - uma estética baseada na simplicidade e na singela pieguice de um barroco reinventado pela precariedade da trupe de saltimbancos que fecha a praça para contar uma história.

$\mathrm{Na}$ cena final, a veraneio se movimenta para trás e revela, sobre um pequeno tablado, o leito de morte dos amantes. Uma das grandes invenções da encenação é transformar o desfecho irreversível da tragédia em alegre 
celebração do ato teatral, a partir da consciência de que a representação se refaz continuamente. (O Grupo Galpão mostra essa capacidade de se refazer quando, dois anos depois, Fernanda Vianna assume o papel de Julieta, substituindo Wanda Fernandes, vítima de um acidente fatal). Antônio Edson encarna o narrador, interferindo furtivamente na história com textos extraídos de Guimarães Rosa e melodias que o ator tira de uma flauta transversal. Romeu, interpretado por Eduardo Moreira, representa em algumas cenas sobre enormes pernas-de-pau, de onde toca acordeão ao mesmo tempo em que sustenta um guarda-chuva. Mercucio, interpretado por Rodolfo Vaz, morre como um palhaço, soltando esguichos de água pelos olhos enquanto rodopia sobre a perua Veraneio. No papel do frei, Chico Pelúcio entra em cena tocando saxofone. Wanda Fernandes faz Julieta como trapezista do circo, equilibrandose de um plano a outro do cenário.

A estréia, na cidade de Ouro Preto, reúne a crítica mineira e paulista. Nélson de Sá considera que o espetáculo substitui o lugar-comum da trama pela criação e pela ingenuidade.

Bárbara Heliodora, em crítica intitulada "A Perfeição da Infidelidade", afirma que Shakespeare "compreenderia muito bem o intuito desta [encenação] e gostaria de se sentir tão querido e tratado com tamanha intimidade".

O espetáculo recebe o Prêmio Shell na categoria especial, em 1994, e é considerado o melhor espetáculo pelo júri popular do Festival de Curitiba. Em 1996, se apresenta com sucesso de público e crítica em várias cidades da Alemanha, em Madri e em Londres, onde anos depois se apresenta na reinauguração do Globe Theater.

Embora existam semelhanças entre $o$ teatro do estudante e 0 teatro estudantil, devemos observar que o teatro de estudantes foi formado por pessoas de nível superior e de um conhecimento de notório saber sobre teatro e que o teatro estudantil é aquele desenvolvido por estudantes de ensino fundamental e médio, na maioria das vezes, com total despreparo para o desenvolvimento do processo teatral.

Quando me refiro a total despreparo, reforço que estou levando em consideração o acesso e o ensino de teatro nas escolas e que essa diferença 
não desmerece e nem atribui conceitos a um ou outro tipo de teatro que, contudo, permite entender e possibilitar a visualização dos processos distintos que ocorrem no teatro do estudante e no teatro estudantil, o qual acredito que jamais devem ser confundidos.

\section{CAPÍTULO II}

\section{Festival Estudantil Sesi Sorocaba de Teatro}

O Festival Estudantil de Sorocaba é realizado, anualmente, pelo período de uma semana. Iniciou com duas apresentações diárias divididas em duas categorias: teatro para criança e adulto. Somente em 2006 passou a ter três apresentações diárias, divididas em três categorias: teatro para criança, adulto e livre.

Após cada apresentação faz-se uma reflexão sobre o trabalho com 0 professor de teatro. O trabalho começou em 2002 e esses sete anos foram objetos da presente pesquisa, projetado no seu aspecto sócio-político e na pedagogia do teatro. Nesse período também estive à frente do Núcleo de Artes Cênicas do Sesi de Sorocaba, no qual sou orientador de artes cênicas, e que me dá suporte para o Festival Estudantil Sesi de teatro.

Sempre acreditei no teatro como linguagem capaz de tornar possível uma reflexão sobre a realidade. Teatro como simulacro verossímil da construção da realidade. Logo que fui convidado para exercer o cargo de orientador de artes cênicas, tive a idéia de que poderia realizar um festival estudantil, pois existia o espaço físico. Eu tinha certeza de que poderia correr 
atrás do que faltasse. Esse convite se deu, em meados de abril, após uma entrevista com a responsável pelo setor de Artes Cênicas do Sesi.

Após o primeiro contato, tudo parecia acertado, apenas aguardava um aceno positivo do $\mathrm{RH}$, e então já via meus ideais serem reformulados e repensados com relação à contribuição que eu poderia dar ao teatro estudantil. Recordo-me que peguei o telefone e liguei para a chefia de setor com a qual apenas havia tido um contato na entrevista para ocupação da vaga e, sem cerimônia nenhuma e com toda ingenuidade, perguntei se ela teria um posicionamento com relação ao início das minhas atividades, pois estava preocupado e desejava ainda naquele ano dar início ao festival estudantil SESI de teatro.

Do outro lado da linha um silêncio tomou conta, logo pensei acho que não vai ser fácil a realização do festival, mas é meu desejo contribuir com o teatro e isso fez com que eu acreditasse na possibilidade de acontecer.

Passou quase um mês para eu ser convocado e assumir o cargo. Não tive dúvidas, nas duas primeiras semanas, fiquei ciente de meu papel e minhas obrigações e de tudo que cercava o Núcleo de Artes Cênicas de Sorocaba. A partir desse momento, vi chegar a hora de começar a colocar em prática 0 festival estudantil.

Iniciei uma conversa com o diretor local, que me apoiou na idéia, mas levantou uma questão importantíssima, a de que não existia verba prevista para a realização deste evento que isso só seria possível com um ano de antecedência e que para aquele ano e o ano seguinte já havia a programação de verba prevista.

Primeiro obstáculo. No mesmo dia, solicitei uma visita da chefia do setor para esclarecer alguns pontos com relação ao núcleo e é claro que o que eu queria era apresentar o projeto do festival e que além de sua aprovação eu também gostaria de contar com o apoio técnico e profissional. Isso não foi difícil, pois eu estava diante de uma pessoa de teatro que também tinha seus anseios e ideais e senti em sua postura uma resposta positiva.

Neste momento, o diretor me situou sobre a parte burocrática da entidade, fiquei pensativo, mas com esses dois apoios, o do diretor local Júlio 
Cezar Martins e da supervisora técnica Sonia Azevedo não tive dúvidas de que o festival iria acontecer. Comecei a estruturação fazendo o levantamento de tudo que precisava. Foi a partir disso, que percebi que não havia pessoal suficiente para me assessorar na estruturação, pois contava apenas com um técnico, um porteiro e com todas as atribuições do cargo de Orientador de Artes Cênicas, e ainda com a necessidade da montagem de um espetáculo para estrear naquele ano dentro do projeto Cena Livre.

Mas, após listar as necessidades, comecei a buscar apoios. A televisão local, afiliada da Rede Globo, a então TV Aliança, tinha um relacionamento considerável com o SESI-Sorocaba, foi a primeira porta em que resolvi bater, marquei uma reunião e lá fui, expus o projeto, num primeiro momento, verbalmente, pois apenas tinha uma folha escrita e mal escrita, até pela dificuldade que tenho de elaborar projetos, mas consegui ganhar a credibilidade da emissora e começamos a negociação.

Percebi também que dinheiro seria difícil, em virtude dos tais planejamentos financeiros. Sem esmorecer, falei das necessidades e pedi uma reunião para dali três dias, para enfim saber o que seria possível. O resultado foi surpreendente, primeiro se consolidou a parceria SESI-TV Aliança e das necessidades básicas, consegui os troféus, camisetas e uma divulgação pela televisão. O festival estava no ar, pois chegamos a gravar um comercial de divulgação. Mas faltava um dos itens mais importante, a comissão julgadora e sem dúvida, eu queria entre os nomes, uma especialista - Ingrid Koudela.

Conversei com dois orientadores de outros núcleos e acertei a vinda deles para fazer parte dos jurados. Então marquei a data do festival para outubro de 2002, juntamente com a Sônia Azevedo, fizemos o regulamento que ainda tinha que ter a aprovação do Departamento Jurídico para poder ser impresso. Com isso acertado, começamos a trabalhar na divulgação. O festival começava a ser conhecido. Grupos já se comunicavam com o Sesi para maiores esclarecimentos. Eu já começava sentir o que um festival estudantil causava. Mas ainda faltavam alguns detalhes.

Consegui, junto com o Sesi local, alimentação para todos os grupos. Mas queria que alguns componentes permanecessem na cidade. Mas onde? $O$ único lugar disponível era o vestiário da piscina do Sesi, de Votorantin o qual 
também é dirigido pelo mesmo diretor local. Não tive dúvidas de que lá iria se tornar um alojamento cinco estrelas. Chegamos à conclusão de que tínhamos tudo: comida, alojamento, o teatro, a parte técnica, mas faltava o corpo de jurados, digo, corpo de jurados porque depois de quase tudo decidido os dois orientadores resolveram simplesmente dizer não.

Não titubeei, corri até São Paulo e pedi uma reunião com a presidente do Sindicato dos Artistas e Técnicos em Espetáculos de Diversões no Estado de São Paulo - Ligia de Paula Souza. Expus o projeto e argumentei que precisava de dinheiro para pagar um corpo de jurados. Ela me pediu uma semana para se reunir com a diretoria, e eu disse: "-Não posso esperar tudo isso!". Ela, diante de meu desespero, pediu para que eu esperasse até o dia seguinte. Fui embora com toda ansiedade possível, como iria realizar um festival sem a comissão julgadora? Foi uma noite terrível. No dia seguinte, já quase no final do expediente, Lígia entra no SESI trazendo o que eu mais precisava ouvir, consegui junto à diretoria o valor para pagar os cachês, eu não sabia se gritava, se chorava ou se agradecia, mas uma coisa eu tinha certeza, o festival iria acontecer.

No dia seguinte, estabeleci o contato mais importante, queria muito trazer Ingrid Koudela e o professor Clóvis Garcia para o festival. Para minha surpresa, Ingrid logo aceitou. Pensei comigo que aquilo nem parecia verdade pois nem havíamos discutido sobre cachê. O professor Clóvis, infelizmente, já tinha assumido outro compromisso e não poderia estar presente no festival. Mas consegui outros dois nomes com tudo isso em andamento, comecei a estruturar mais coisas. Convidei Ms. Marli Bonome, então coordenadora do Curso de Artes Cênicas da Universidade Sagrado Coração de Bauru, se era possível sua vinda para uma oficina durante uma semana, ao que ela prontamente aceitou o convite.

Dei-me conta de um pequeno detalhe, os jurados e a oficineira precisavam de hospedagem e alimentação, conseguimos então um hotel através de patrocínio e alimentação. A estrutura do festival estava montada e iniciava ali o Festival Estudantil Sesi Sorocaba de Teatro.

Dia 14 de setembro de 2002, dá-se o início ao 1ํ Festival Estudantil SESI-TV Aliança na cidade de Sorocaba/SP, onde foram apresentados 
espetáculos, como: O cordão Umbilical e Viagem ao faz de conta, ambas dirigidas por mim, Júnior Mosko.

Dez grupos teatrais, formados por alunos da rede pública estadual, estavam reunidos em Sorocaba para participar do $1^{\circ}$ Festival que aconteceu nos dias 16 e 20 de setembro de 2002. O evento teve como objetivo estimular o interesse dos alunos e revelar novos talentos através dos núcleos formados nas próprias escolas. Nesta primeira edição do festival foram selecionadas cinco peças na categoria adulta e cinco na categoria infantil.

A abertura do evento aconteceu no dia 16/09/2002, às 14 horas, no teatro do Sesi, com a apresentação da peça $O$ rapto das cebolinhas, de Maria Clara Machado, direção do professor André Luiz Camargo, da Escola Estadual Chico Pereira, de Tatuí.

\section{Histórico dos Festivais estudantis do SESI Sorocaba}

\section{1ํ Festival Estudantil SESI Sorocaba 2002}

O $1^{\circ}$ Festival Estudantil SESI de Teatro, até então levava o nome festival SESI TV Aliança, pois se tratava de uma parceria com a afiliada da TV Globo e com o apoio do SATED/SP. Recebemos 93 inscrições, um número que não só superou as expectativas, como me amedrontou. Eu e Sônia Azevedo fizemos a Curadoria dos espetáculos.

Pela primeira vez, talvez, tenha me sentido impotente por ter que selecionar os espetáculos. A minha vontade era que todos aqueles trabalhos fossem apresentados, não sabia ao certo se estava na função correta, a emoção falava mais alto, em cada abertura dos envelopes, Sônia e eu mergulhávamos nos trabalhos e entre bolachas, cafés anotávamos, assistíamos aos vídeos, emocionávamo-nos, discutíamos e não chegávamos a um acordo tão facilmente, pois ela, totalmente técnica, e eu escorregando pela emoção. Mas durante quatro dias chegamos ou, pelo menos, acreditamos ter chegado a melhor escolha na categoria infantil, foram selecionados os espetáculos: O Rapto das Cebolinhas, de Maria Clara Machado; O Feitiço dos 
Deuses, de Marilu Tavares; A Lenda da Velha da Floresta, de Reginaldo Gagliardo; Soltando o Verbo, de Zé Carlos de Andrade; Beijo Não, de Tatiana Belinky. Na categoria adulto: O Caixeiro da Taverna, de Martins pena; Quase Van Gogh, de Aziz Bajur; Dança dos Espelhos, de Vanderley Carneosso; Viúva Porém Honesta, de Nélson Rodrigues; Geração Coca-Cola, de Ronaldo Ciambroni.

Ali estavam os dez espetáculos selecionados que seriam analisados por Ingrid Dormien Koudela, Marli Bonome e Tércio Marinho.

Com o interesse de fecundar realmente o que podemos chamar de teatro na escola, o Festival inicia e chegam algumas perguntas, quanto à seleção dos espetáculos. Questões como: o que fazer e como informar aos grupos não selecionados e como explicar a não seleção, não de um espetáculo, mas de um processo pedagógico, que interfere na comunidade, mas assim tinha que ser feito.

Passada essa fase que para mim, particularmente, é um dissabor, começamos na montagem do festival. Como já citei, as dificuldades foram muitas. O espetáculo que abre o Festival Estudantil é O Rapto das Cebolinhas, da Clarinha, como assim carinhosamente eu a chamava, mestra Maria Clara Machado, veio naquele momento em que o espetáculo estava majestosamente no palco a me trazer muitas reflexões. Aquelas crianças na platéia e aquelas crianças no palco representando, davam-me uma sensação de que um especial caminho estava começando a ser trilhado. É claro que vieram muitos flashes de lembranças, mas muitos mesmo, como a participação em outros festivais, no qual eu estava como participante. De repente me vejo sentado ao lado da comissão julgadora, ao lado de minha superior técnica, Sônia Azevedo, desfrutando de um momento único, que de tão singular para mim, misturava a minha criança, o meu profissional, a minha emoção e a minha responsabilidade e muitas incertezas.

Confesso que ao ver tudo acontecendo pensei em recuar, pois não sentia que tinha tanto embasamento para prosseguir. Minha emoção era tal que, quando se iniciou o primeiro debate, minha mão suava fria, minha voz estava totalmente embargada. Tive que fazer a abertura do debate que acontecia em uma sala anexa ao teatro, não sabia como começar, pois as 
minhas referências sempre estiveram como a de um participante e não como de um organizador e coordenador. A responsabilidade era muito grande, pois estava ao lado de especialistas como Ingrid Koudela e à frente de um grupo que vinha da cidade de Tatuí, a cidade que realizava até então o mais importante Festival Estudantil.

Os meus olhares, a minha percepção e muito do que cresci ouvindo foram construídos e amadurecidos nos debates daquele festival.

E a criança também escolhe o seu brinquedo sua conta própria não raramente entre aos objetos que os adultos jogam fora, as crianças "fazem historia a partir do lixo da história". É o que as aproxima dos "inúteis", dos "inadaptados" e dos marginalizados (Benjamin, 1984, p. 14).

Ficava muito preocupado porque não queria que fosse uma cópia, mas, as referências eram muito fortes, porque voltei a ser criança vivenciando aquele festival. E esta foi minha escolha, este foi o "brinquedo" que resolvi desmontar e montar para me apropriar dele.

Ao findar o primeiro debate, agradeço a todos e percebo que o festival está acontecendo e já começamos a nos preparar para a apresentação do primeiro espetáculo adulto. As pessoas que estavam alojadas ficaram por ali mesmo para poder se alimentar e assistir ao espetáculo. Vem a preocupação técnica. Será que dá tempo da montagem do segundo espetáculo? Porque até então estava lá Claudinei Rosa, técnico do teatro, com a ajuda de alguns alunos do Núcleo de Artes Cênicas de Sorocaba e a fila do lado de fora já era uma mostra do que seria o público daquela noite.

Quando o festival inicia, percebo que tecnicamente deu certo. Teatro lotado. As cortinas se abrem no horário exato e vamos para mais um espetáculo em que ao fim se dá um debate. Tudo transcorre em perfeita harmonia, sinto nos participantes uma confiança depositada no festival, mesmo que ainda não soubesse ao certo o que pensavam os especialistas que ali 
estavam trabalhando para avaliar os espetáculos. No terceiro dia de festival, fomos surpreendidos pelo espetáculo Dança dos Espelhos da cidade de Jundiaí, digo surpreendido, pois me senti um pouco lesado com relação ao material que fora enviado e a apresentação que se deu no palco. Percebi que a comissão que analisava ficou incomodada com o que ali estava vendo, mas, enfim, partimos para o debate.

Os especialistas apontavam problemas que, realmente, foram pontos determinantes do processo pedagógico apresentado, muitos equívocos foram levantados, como pesquisa de campo que o diretor levava alunos jovens a fazer de maneira duvidosa, ao qual aqui não cabe julgamento. $O$ domínio que 0 diretor exercia sobre aqueles jovens que tinham apenas aquele modelo de teatro como referência e à maneira como ele conduzia a direção, como se adestrasse animais. O desconforto não ficou restrito apenas aos especialistas, mas também a outros professores que acompanhavam 0 debate e se colocaram. Eu me senti angustiado, pois tinha que conduzir todo o debate sem me envolver emocionalmente no assunto, quase que impossível para uma pessoa como eu. O debate se estendeu por quase três horas e meia.

Os jornais noticiavam tudo o que acontecia no festival. Minha surpresa e meu contentamento eram enormes e o festival transcorreu com sucesso. $\mathrm{Na}$ noite de premiação, o ator Sérgio Mamberti deu-nos a honra de sua presença e veio participar da entrega de prêmios e também falar sobre a importância do festival que a partir daquele momento se instaurara.

Muitas questões ficaram para mim, como artista educador, sobre o rumo que o festival iria tomar, porque não foi fácil levar a cabo esse primeiro. Por conseguinte, tinha a incerteza se conseguiria realizar o segundo, não por falta de dedicação, mas acreditava que uma avaliação das empresas envolvidas como a TV Tem e SESI seriam ponto de fulcral importância para uma continuidade do festival.

Os números apontaram que durante o festival tivemos um público de 3.800 pessoas.

Logo chegou o parecer da comissão julgadora que consta nesta pesquisa por considerar e entender sua importância. 


\section{Parecer da Comissão Julgadora}

O Festival estudantil de Teatro promovido pelo SESI Sorocaba contou com parcerias imprescindíveis em sua realização: a TV Aliança e o SATED/SP.

A TV Aliança, registrando todo o processo, não só forneceu a confiabilidade ao público que compareceu em massa às apresentações, como divulgou na mídia anônimos grupos que, timidamente, oportunizaram gerar grandes ações nas comunidades onde se inserem.

O SATED/SP (Sindicato dos Artistas e Técnicos em Espetáculos de Diversões no Estado de São Paulo) abraçou a causa e fez-se observador direto do evento, pretendendo direcionar ações para seu desenvolvimento futuro e reconhecendo assim, a legitimidade do profissional que trabalha com teatro na educação na região de Sorocaba. O sindicato abrigou e promoveu durante os últimos dezessete anos um festival estudantil de teatro no conservatório Dramático de Tatuí que, sem dúvida, fez um trabalho pioneiro.

Júnior Mosko, na condição de orientador de Artes Cênicas do Sesi, com grande propriedade, fez a proposta de realização do primeiro festival estudantil de teatro do SESI, buscando formas de inovar com parcerias fundamentais.

Através da reflexão de cada debate, após as apresentações, surgiram ações a serem desenvolvidas no contexto do teatro na escola.

O profissional responsável pelo trabalho com a criança ou jovem deve ser necessariamente um professor da escola sendo de preferência licenciado na área de artes cênicas.

Justifica-se tal exigência pela constatação da existência de atividades realizadas nas unidades escolares por autodidatas, "amigos da Escola", que comprometem o ensino/aprendizagem do teatro e o saudável desenvolvimento dos alunos.

Constatou-se que em sua grande maioria os trabalhos de teatro são realizados fora do horário escolar freqüentemente nos finais de semana, de forma voluntária.

Os parcos recursos não contemplam necessidades específicas para o desenvolvimento do trabalho cultural na escola. A atividade teatral faz parte de 
projetos desenvolvidos pelos professores que implicam trabalho para o qual não há empenho e destinação de verbas. Alguns grupos participam do festival arcando pessoalmente com as despesas de transporte e produção de seus espetáculos. A organização do festival registrou a inscrição de 98 espetáculos, sendo em sua maioria oriundos de escolas estaduais. No ato da inscrição, foram enviados vídeos com o objetivo de selecionar os trabalhos e dos dez escolhidos, apenas um de escola particular.

Os depoimentos de diretores, coordenadores pedagógicos, professores e pais de alunos revelam transformações provocadas na escola através do teatro, que se constitui como um poderoso instrumento de educação.

Os grupos de teatro das unidades escolares promovem circuitos culturais interdisciplinares e interinstitucionais e todos os componentes dos grupos mostraram o entusiasmo com que são recebidos e satisfação na realização do evento.

A articulação entre sindicato, escola pública e as universidades podem vir a ter como objetivo mapear e identificar a pesquisa, a legislação e o âmbito de atuação do teatro na educação, visando não apenas grupos de teatro na escola, como a própria função do teatro na educação.

Os membros da comissão julgadora constataram a necessidade de promover novas mostras de teatro, nas quais poderão ser incorporadas atividades como oficinas pedagógicas, seminários e debates.

Faz-se necessário também promover a divulgação das pesquisas realizadas nas universidades em nível de pós-graduação na área, tornando-as acessíveis aos professores de educação infantil, do ensino fundamental e médio.

Seria recomendável ainda instrumentalizar o professor através de cursos periódicos realizados regionalmente.

Comissão julgadora: Ingrid Dormien Koudela ${ }^{5}$, Marly Bonome ${ }^{6}$, Tércio Marinho ${ }^{7}$.

49

5 Ingrid Dormien Koudela: formou-se Bacharel em Teatro pela ECA/USP(1972) onde fez Mestrado e Doutorado.Livre Docente pela ECA/USP orienta atualmente teses de Mestrado e Doutorado no Departamento de Artes Cênicas. Tem Vários livros publicados no Brasil e no 


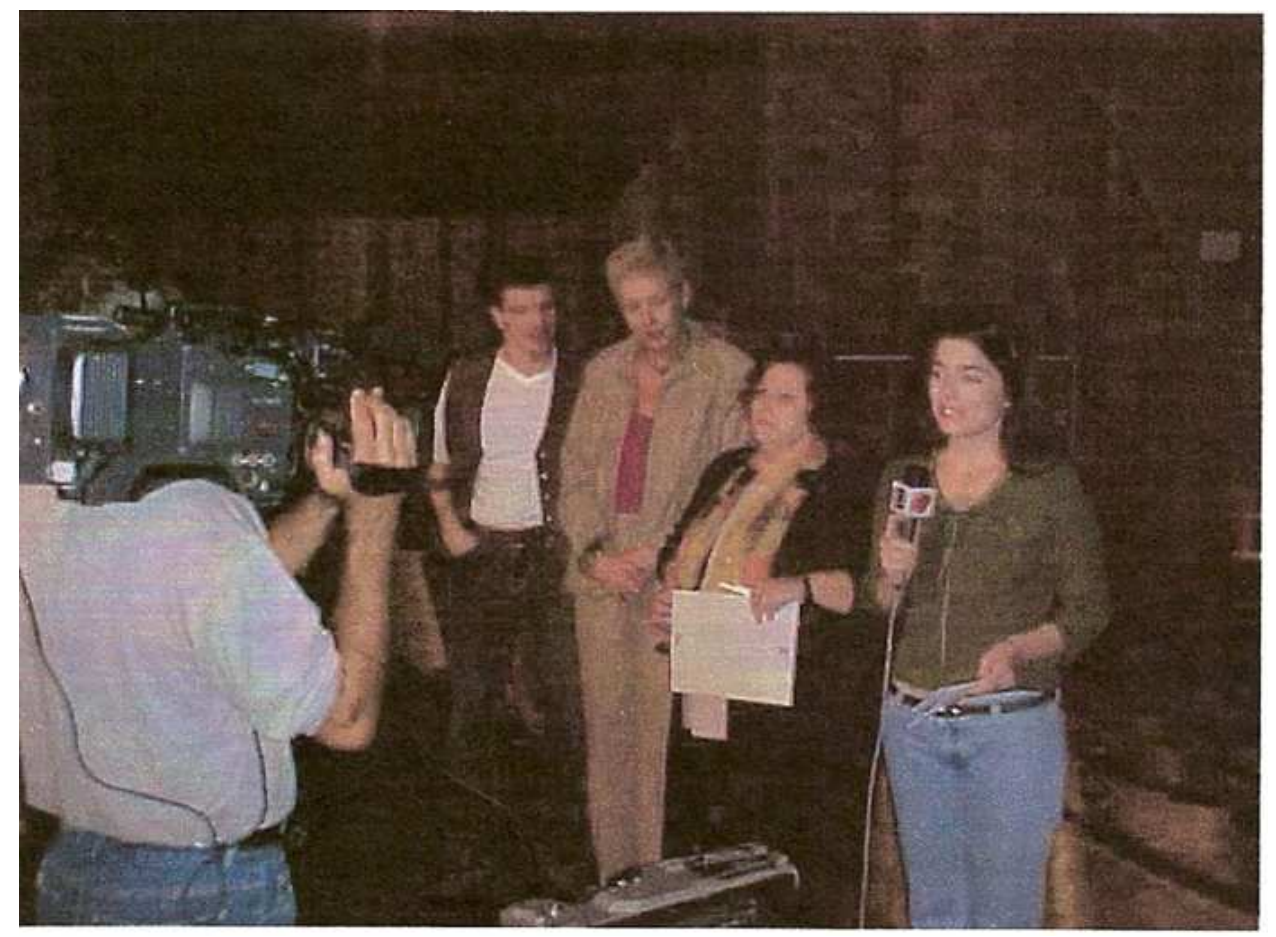

Momento da entrevista feita pela jornalista Kelly Varrasckin, da então TV Aliança parceira do festival, com a comissão julgadora Tércio Marinho, Ingrid Koudela e Marly Bonome. Onde os jurados expuserem a importância do Festival.

exterior, sendo introdutora do método de Viola Spolin entre nós. È Tradutora e estudiosa de Bertold Brecht, com ênfase no seu projeto com a Peça Didática. Atualmente, vem expandindo seu trabalho de ensino e pesquisa através de projetos ligados à Secretaria Municipal de Educação (SP) e da FEUSP - Faculdade de Educação, dando continuidade à formação de professores de Arte, realizando consultoria e pesquisa na área de Teatro. É coordenadora do Grupo de Trabalho em Pedagogia do Teatro na Educação da ABRACE - Associação Brasileira de Artes Cênicas, através do qual vem promovendo o encontro e a troca de experiências de especialistas na área. É consultora da PANANCO DO BRASIL para Teatro Infantil, de desenvolvendo o projeto LEVA AO TEATRO (1999-2002).

6 Marly Bonome: Bacharel em Teatro pela ECA/USP, Mestre em Teatro pela ECA. Coordenadora do Curso de Artes Cênicas da USC, docente das disciplinas: Teatro Educação, Cenografia, Técnicas Teatrais. Diretora teatral do Teatro Universitário Veritas da USC, em Bauru. Participou como membro do júri de diversos Festivais de Teatro pela Secretaria de Estado da Cultura de São Paulo onde trabalhou durante dez anos.

7 Tércio Marinho: 42 anos, natural de São Paulo, é ator/dançarino, como especialização em Administração de Projetos Culturais. 

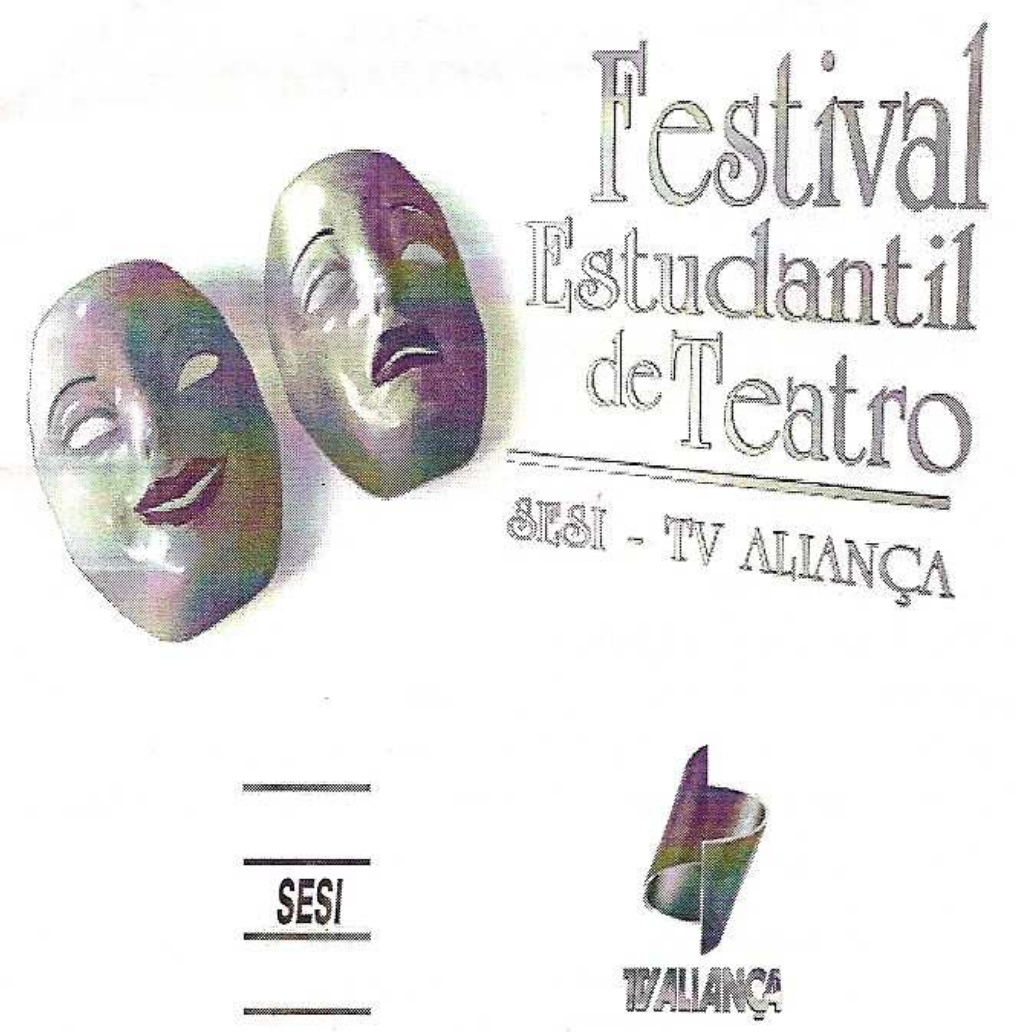

apoio:

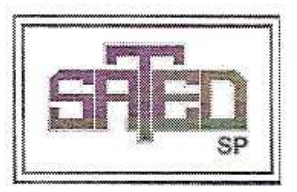

SECRETARIA

DE ESTADO

DA CULTURA

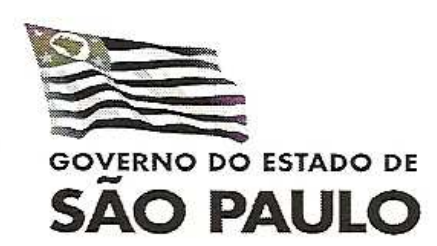

O 1ำ programa foi colocado da forma em que foi concebido inicialmente, devido aos parcos recursos que tínhamos e não podia ser diferente face às dificuldades vividas no começo de tudo. 


COORDENAÇÃO
Antonio Augusto de Moraes Massi
Fernando Miranda Ribeiro
Ligia de Paula
Manoel Rodrigues
SUPERVISÃo TÉCNICA
Sônia Azevedo
COORDENAÇÃO GERAL
Junior Mosko
SUPERVISÃO GERAL
Julio Cesar de Souza Martins

\author{
RECEPÇÃO DOS GRUPOS: \\ Lucilene Fernanda \\ Felippe Moraes \\ Camila Darros \\ PORTARIA \\ Rogério Adriano Casquez \\ TÉCNICO RESPONSÁVEL \\ Claudinei de Jesus Rosa \\ ATENDIMENTO AOS JURADOS \\ Fernanda D'Almeida \\ APOIO LOGÍsTICO \\ Carolina Regina Sampaio Mendes \\ Irani Ferreira da Rocha Andrade \\ Mara Cristina Fala \\ Thaisa Candini Maragato \\ Valdemir Pinto \\ Carlos José Fioravante \\ Sandra Maria Moura \\ Gilson Ferrari \\ Kelten Sá \\ Rita de Cássia \\ Carlos Tadeu \\ Agemiro Batista Junior \\ Kátia Regina Daher
}

Apoio:

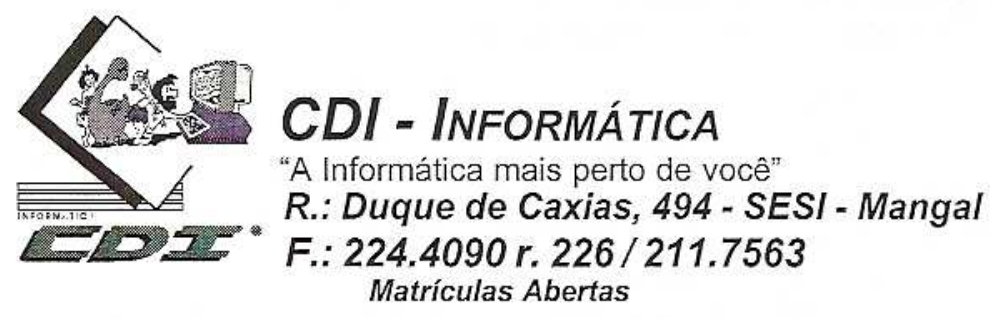




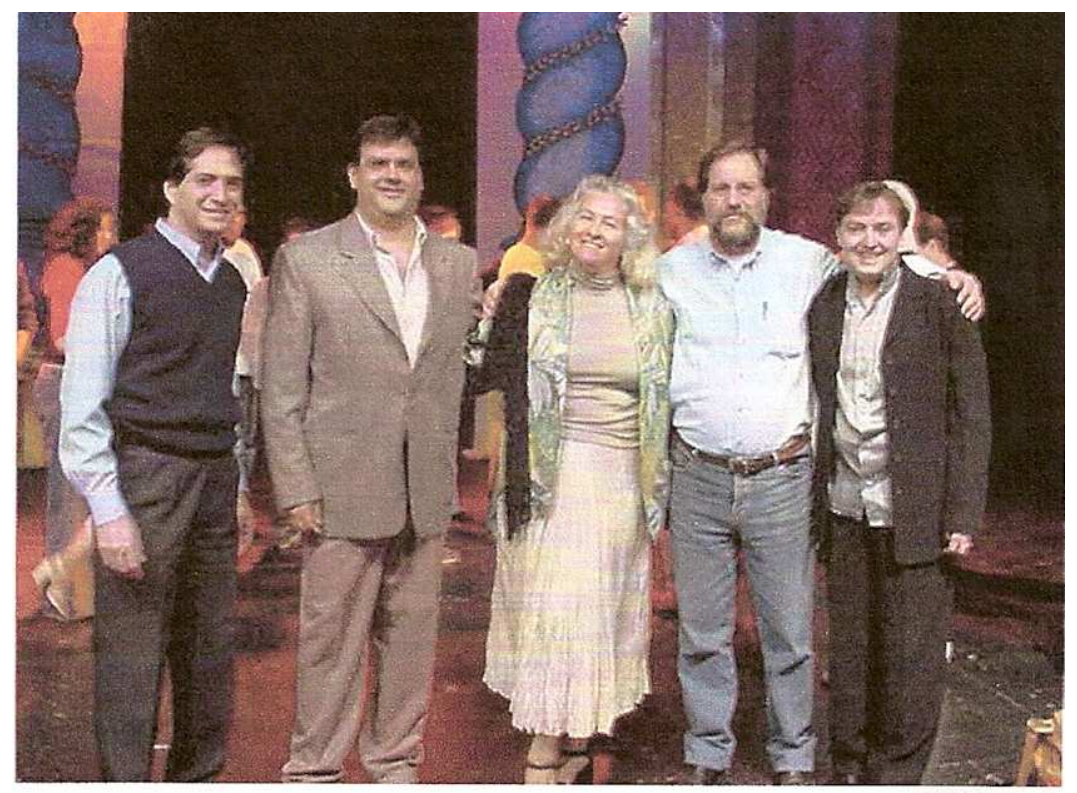

Foto histórica dos parceiros do Festival, Fernando Miranda (TV Aliança), Julio Martins (SESI), Lígia de Paula (SATED/SP), Manoel Rodrigues (Oficina Cultural) e Junior Mosko. 


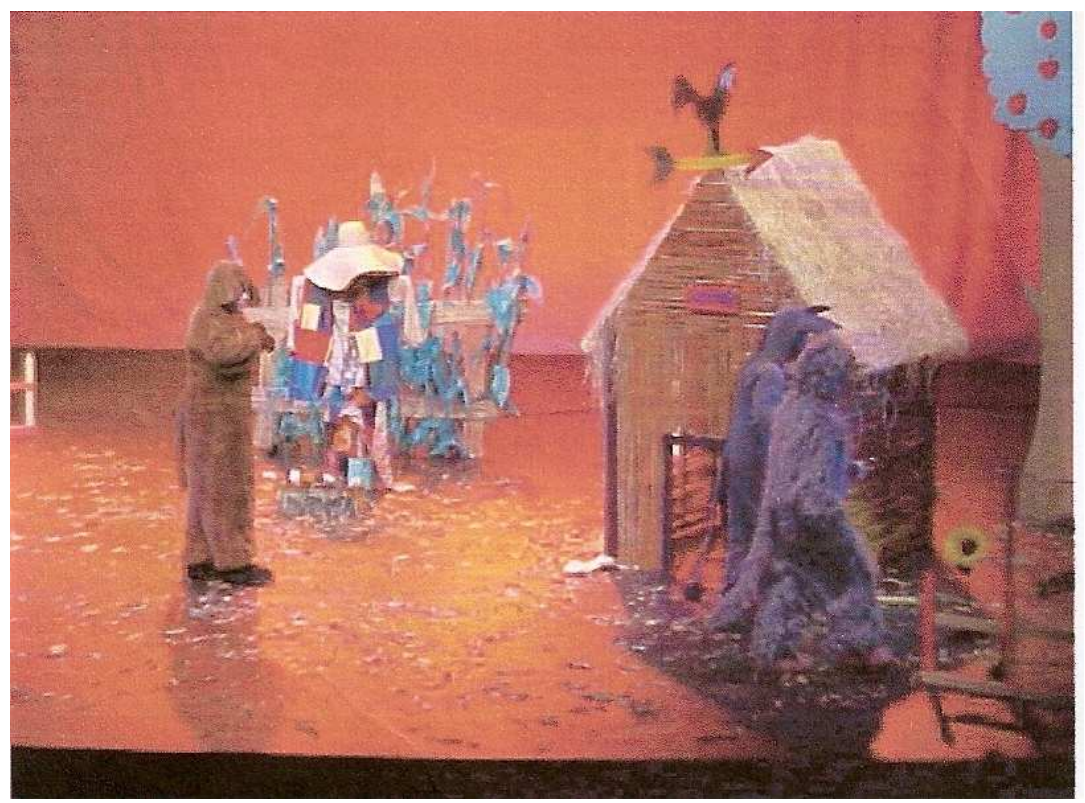

O RAPTO DAS CEBOLINHAS

A CIA Pereirão de Teatro participou do $1^{\circ}$ Festival Sesi Sorocaba de Teatro, com o espetáculo $O$ rapto das cebolinhas, de Maria Clara Machado, com direção do professor artista André Luiz de Camargo. A escola a qual faz parte a $C I A$ já tem uma tradição em montagens de espetáculo de teatro desde os anos 1980, ela vem participando de festivais como o festival estudantil de Tatuí, e a CIA Pereirão de Teatro retomou as atividades neste ano para participar deste festival em questão depois de ter parado por quase 10 anos. 


\section{Segunda $16 / 09$ \\ CATEGORIA INFANTIL \\ O RAPTO DAS CEBOLINHAS}

\section{RELEASE}

O Rapto das Cebolinhas, é um clássico do teatro infantil brasileiro de Maria Clara Machado. Descobrir quem está roubando as preciosas cebolinhas que dão longa vida é tarefa arriscada para os netos Maneco (Elton Pinheiro) e Lúcia (Marilia Teixeira) do Corenel Fenício (João Armando Fabbro). Esta é a trama central que vai envolver os bichos do sítio como o burro Simeão (Fernando Henrique Casalunga), a gata Florípedes (Jackeline Gabriel Cardoso) e o cachorro Gaspar (Erick Sotero), além do astuto e perigoso Camaleão Alface (Thiago Castro Leite). Não escapa nem o médico (Luciana de Oliveira) que vai tentar salvar a vida de alguns personagens.

\section{DADOS}

Espetáculo : O Rapto das Cebolinhas Autor: Maria Clara Machado Grupo : Cia Pereirão de Teatro Escola: Escola Estadual Chico Pereira Cidade: Tatui

\section{ELENCO}

João Armando Fabbro: Coronel Felício Thiago Castro Leite: Camaleão Alface

Elton Pinheiro: Maneco

Marilia Teixeira: Lúcia

Erick Sotero: Gaspar, O Cachorro

Jaqueline Cardoso: Florípedes, A Gata

Fernando H. Casalunga: Simeão, O

Burro

Luciana de Oliveira: Médico

\section{FICHA TÉCNICA E ARTÍSTICA}

Diretor do Espetáculo: André Luiz

Camargo

Figurino: Sérgio da Silva Franco

Cenografia: João A. Fabbro e Thiago de Castro Leite

Sonoplastia: André Luiz Camargo Iluminação: André Luiz Camargo

Maquiagem: Marília Teixeira e Jaqueline Cardoso

Produção: Cia Pereirão de Teatro da E.E."Chico Pereira" - Sec. Educação

Operador de Som: João Carlos Baldasseirine

Operador de Luz: André Luiz Camargo Contra-Regra: Anna Cristina Silva Costa 


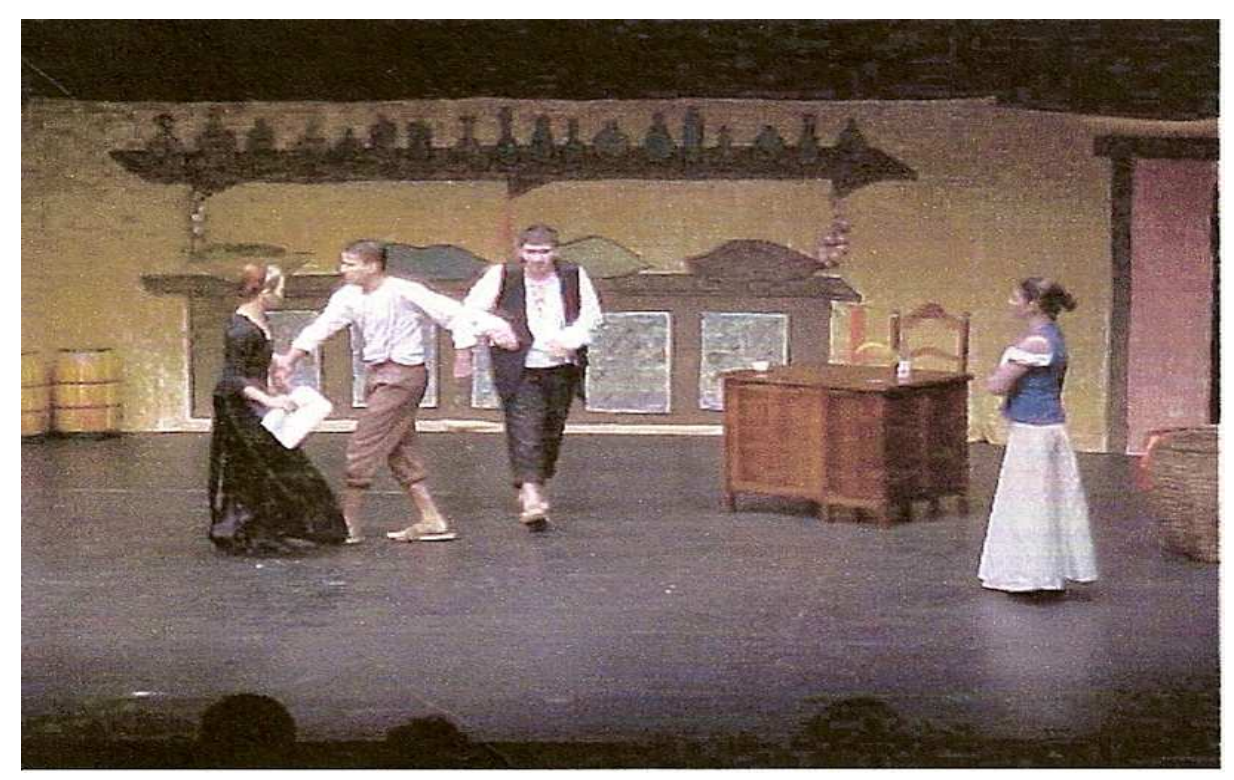

O CAIXEIRO DA TAVERNA

O grupo Família Matula de Teatro iniciou seu trabalho com este espetáculo, que tinha à frente o professor de Português Rubens Espírito Santo, que dirigia o espetáculo e comandava o grupo. Eles ensaiavam sempre aos sábados e domingos, em um barracão da igreja, onde o pai de um dos integrantes era diácono e facilitava a entrada do grupo clandestinamente, pois, o salão paroquial não podia ser usado para os devidos fins, embora este grupo tenha tido todo apoio da escola, na mesma não se encontrava espaço físico, devido a uma reforma, e os espaços transformaram-se todos em sala de aula.

O processo de trabalho do grupo ficou muito nítido, era evidente que não estavam em busca, no primeiro plano, do caráter espetacular e sim do processo, embora com bastante dificuldade de material de pesquisa e conhecimento. Mas já se percebia a inquietação do ator Francisco Neto, e que era o começo de uma trajetória. 


\section{CATEGORIA ADULTO \\ O CAIXEIRO DA TAVERNA}

\section{RELEASE}

Comédia clássica de Martins Pena, O Caixeiro da Taverna é mais uma história qu o autor se utiliza para fazer crítica aos costumes da sociedade do Rio de Janeiı de 1845, e, incrivelmente, ainda consegue agradar ao público dois séculos d pois, devido à trama bem elaborada e à linguagem fácil e ágil, sempre present nas obras desse nosso mestre dramaturgo do século XIX.

Numa taverna do Rio de Janeiro, o primeiro caixeiro Manuel, matuta seus planc para se tornar sócio do estabelecimento, com a viúva D. Angélica.

Francisco, um oficial de latoeiro inconformado com invasão de mão de obra e: trangeira nos país, pois vem minando seu mercado de trabalho, pretende casar-s com a viúva para melhorar sua situação. Como é amigo de Manuel, vem comun car-lhe sua intenção, o que causa pânico no ambicioso caixeiro que vê seus pl: nos irem por água abaixo se esse casamento acontecer.

Manuel, casado em segredo com bela Deolinda, irmã do Sargento Quintino, faz impossivel para conseguir a sociedade, antes da verdade vir à tona. Será qu consegue?

Uma trapalhada de Martins Pena, mostrando de forma satírica, o amor, a ambiçãı os problemas de um Brasil remoto, mas com características que prevalece at hoje.

\section{DADOS}

Espetáculo: O Caixeiro da Taverna Autor: Martins Pena

Grupo: Família Matula de Teatro

Escola: E.E. "Prof. Lauro Sanchez"

Cidade: Sorocaba

\section{ELENCO}

Francisco Antonio Neto: Manuel

Pacheco

Mônica Messias: D. Angélica

Luis Fernando Aires: Francisco

Alessandra Prandi: Deolinda

Jairo Leme: Sargento Quintino

Wellington Barbosa: Toninho
FICHA TÉCNICA E ARTÍSTICA

\section{Diretor Do Espetáculo: Rubens}

Espirito Santo

Figurino: Rinaldo Grilo Filho

Cenografia: Francisco Antonio Neto,

Luis Fernando Aires, Mônica Messias

Sonoplastia: Rubens Espirito Santo

Iluminação: Rubens Espirito Santo

Maquiagem: Grupo

Produção: E.E. "Prof. Lauro Sanchez

e Grupo

Operador De Som: Joyce Angelina

Caus

Operador De Luz: Rubens Espirito

Santo

Contra-Regra: Gislene Freitas 


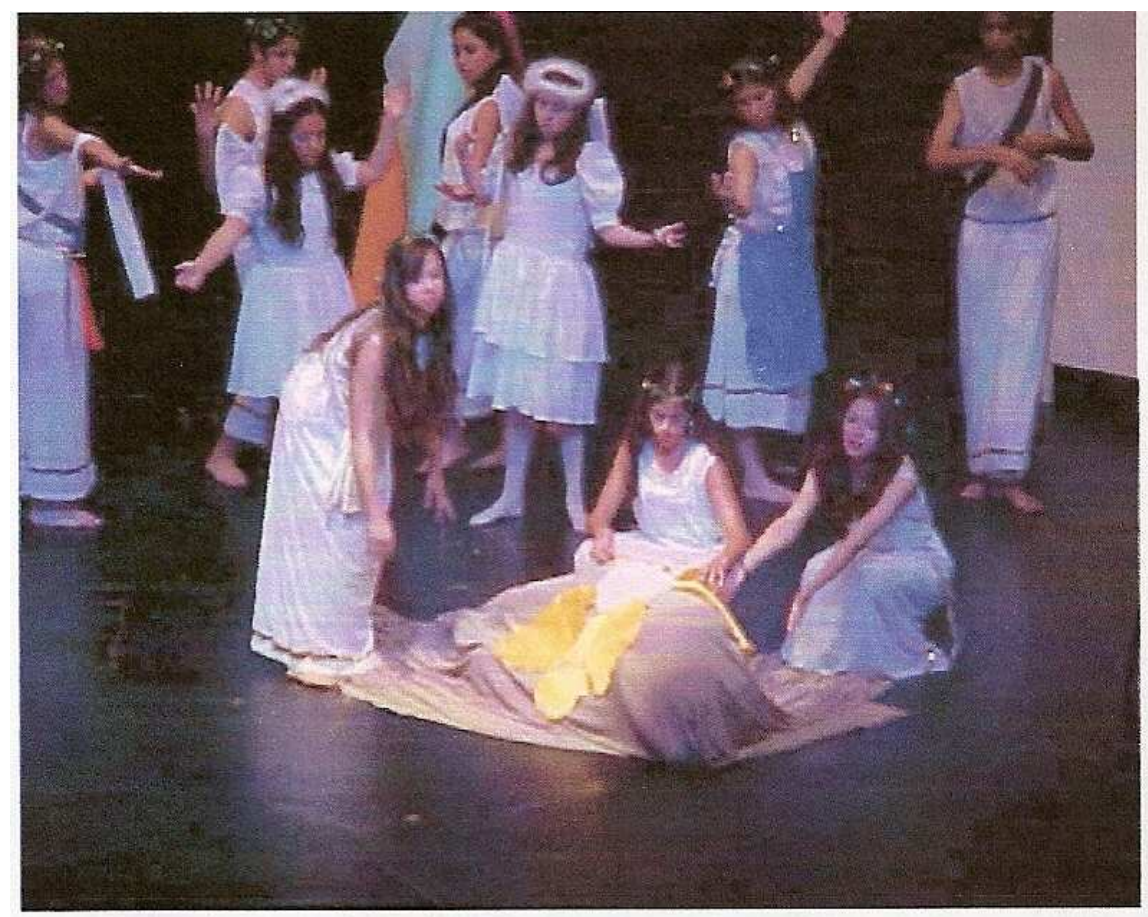

\section{FEITIÇO DOS DEUSES}

O espetáculo Feitiço dos Deuses, com direção da profạ. Maria Rosa Amorim, foi classificado para o festival, mediante material gravado durantes os ensaios e pelo material de inscrição elaborado pela professora. Mas em sua realização durante o festival, percebi que não havia uma proposta de processo de vivência das crianças com o conteúdo do texto. Em função disso, os equívocos eram o tempo todo evidenciados, as crianças e os adolescentes que faziam parte do espetáculo, não compreendiam nem mesmo a estória que estavam encenando.

Era visível que o elenco simplesmente tinha decorado o texto, colocado o figurino imposto pela professora para participar do festival. Foi um espetáculo personalista, no qual a professora não tinha embasamento nenhum para estar à frente do grupo, deixando claro que ela, não só na apresentação como também durante o debate, não estava preocupada com o processo e muito menos com os alunos, sua preocupação era o espetáculo que iria ser apresentado e os prêmios que possivelmente poderia levar para a escola. 
Terça $17 / 09$

\section{CATEGORIA INFANTIL}

\section{FEITIÇO DOS DEUSES}

\section{RELEASE}

O Texto de Marilu Tavarez é uma interessante metalinguaguem com adolescentes preparando-o para encenar uma peça no colégio. Abordando situações típicas, ou seja, os grandes amores, narrados por demônio muito engraçado. Elas são conhecidas como DEUSIXVÊNUS; ROMEUXJULIETA; ÉDIPOXJOCASTA; E OS DEUSES DO OLIMPO.

\section{DADOS}

Espetáculo: Feitiço dos Deuses Autor: Marilu Tavarez Grupo: Grupo Teatral Gallicho Escola: E.E. "Prof. André Xavier Gallicho"

Cidade: São Paulo

\section{ELENCO}

Mário Augusto Garcia e Paula L. E. Barbosa: Ama

Fernando Gomes da Silva: Apresentador

Giovanna Alves Trapani e Juliana

Moreira Argachoff: Anjos

Nathaly Telma Rendo: Atena

Marianna Alves Trapani: Demônio Sheyla Cristina Eneas Barbosa:

Deusa

Isabel Cristina Pereira da Silva: Eco

Fernando Gomes da Silva: Édipo

Nathalu Telma Rendo: Eros

Thais Lucia Valciano: Hera

Marcelo Francisco Farahat Tazzetti:

Hermes

Sheyla Cristina Eneas Barbosa:

Jocasta

Nathaly Telma Rendo: Julieta
Vanessa Hellen Fonseca Mori: Mãe

Nathaly Telma Rendo: Monstro

Marcelo Francisco Farahat Tazzetti:

Narciso

Samara Alencar Pinto e Camila Vieira

Primo: Ninfas

Sheyla Cristina Eneas Barbosa: Oráculo

Isabel Cristina Pereira da Silva: Padre

Sheyla Cristina Eneas Barbosa: Páris

Fernando Gomes da Silva: Pai

Nathaly Telma Rendo: Psiquê

Marcelo Francisco Farahat Tazzetti:

Romeu

Marcelo Francisco Farahat Tazzetti:

Tiresias

Vanessa Hellen Fonseca Mori: Vênus

Fernando Gomes da Silva: Zeus

FICHA TÉCNICA E ARTÍSTICA

Diretor Do Espetáculo: Maria Rosa

Amorim

Figurino: Maria Rosa Amorim

Cenografia: Maria Rosa Amorim

Sonoplastia: Grupo

Iluminação: Maria Rosa Amorim

Maquiagem: Grupo

Produção: Maria Rosa Amorim

Operador De Som: Sayuki Yamaoka

Operador De Luz: Sayuki Yamaoka

Contra-Regra: Sayuki Yamaoka 


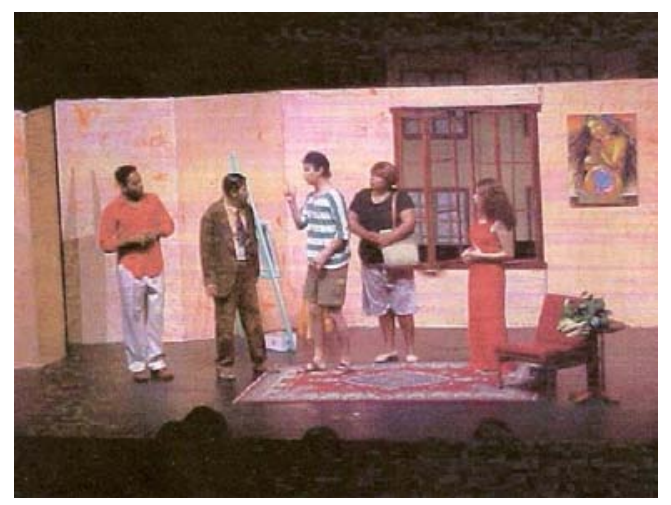

QUASE VAN GOGH

O espetáculo Quase Van Gogh veio de Carapicuíba, de formação de alunos da periferia, mais precisamente da $\mathrm{COHAB}, \mathrm{O}$ novato diretor Mário Félix, tinha escolhido trabalhar com o grupo na escola, mas sem noção nenhuma sobre montagem, decidiu assistir alguns espetáculos em Osasco, e foi à luta como assim enfatizou, construiu tudo a partir da realidade vivenciada por aqueles alunos.

O espetáculo tinha uma mistura realista no cenário e figurino, mas em sua encenação era quase que transformado em um bufão. Na estréia que aconteceu no festival, contou com a presença do autor Azis Bajur, que durante o debate se manifestou, não sobre a obra, mas da determinação daqueles jovens, e é claro que o que evidenciou esse grupo foi, o fato de que todos eram de uma classe menos favorecida economicamente e estavam em busca de um teatro. Relataram-me que buscavam profissionais para que fossem até lá, na sede do grupo, uma sala de um centro comunitário, para que fossem dadas oficinas e maiores informações, pois muitos não podiam ir até a cidade vizinha, Osasco, muito menos a São Paulo para assistir ou participar de aulas de teatro. Como foi um grupo que marcou muito sua passagem pelo festival, pelo interesse e pela forma que conduzia o processo, este ano entrei em contato, para saber sobre o grupo.

Fui informado que uma das atrizes estava encarcerada, os outros dois não se sabe que destino tomaram, um dos atores segue a carreira amadora, mas ainda esta em busca, e o diretor passou a trabalhar como professor após concluir graduação. 


\section{CATEGORIA ADULTO}

\section{QUASE VAN GOGH}

\section{RELEASE}

Quase Van Gogh: Um pouquinho do que somos.

Sabe se que o processo de criação das obras de arte é realizado à partir de um entrelac mento textual que caracteriza a condição da legibilidade da literária: em Quase Van Gor Aziz Bajur, além de assimilar duas histórias (meta-teatro) usa elementos de sua peç anteriores, questões sociais, e políticas, inseridos na ação dramática de Matheus, que Gilson. As narrativas inseridas, referem-se a desvalorização do artista atual e seus con tos internos em razão a sociedade que se encontra. A presença do personagem "Mathe Van Gogh da Silva" que é interpretado por um ator que sofre com a esposa e deve conc mínio, se iguala, a fazer o público se confundir se Matheus é Gilson, ou vice-versa.

O conflito cômico, exacerba o jogo dramático de mão dupla do vai-e-vem da vida, carac riza o movimento pendular ininterrupto entre a ficção e a realidade, personagens-atores visão clara sob esse aspecto, só se concretiza após ofato de um espectadora interrompe espetáculo a procura de um personagem, ou melhor, a procura do ator. Apesar de : bastante confusa inicialmente, o que se torna uma "confusão" necessária nessa encer ção; considera a entrada dessa espectadora (personagem), ser um recurso criativo e di vendando da trama apresentada, desvendando o caráter de todos os personagens.

A ação dramática do texto teatral "Quase Van Gogh" Apesar de enfocar as pequenas si ações do cotidiano artístico, na esfera teatral que são marcadas por desencontros, assas nato, suspense, vingança, traição, decepções, é emoldurada numa comédia deliciosa espetáculo se encerra com um final surpreendente, onde o público se pergunta, ou afirma, quase Van Gogh. Somos o que somos.

\section{DADOS}

Espetáculo: Quase Van Gohg

Autor: Aziz Bajur

Grupo: Os Camaleõs

Escola: E.E. "Prof. Ricardo Antonio

Pecchio"

Cidade: Carapicuiba

\section{ELENCO}

Robson Picker: Mateus Van Gohg

Kelly Ribeiro: Leonor/Patricia

Sergio Henrique: Irineu/Ernesto

Mauro Felix: Pestana 1 e 2

Vania F. de Souza: Dilma

Flavio Kotty: Gil
FICHA TÉCNICA E ARTÍSTICA

Diretor Do Espetáculo: Mauro Felix

Figurino: Robson Picker

Cenografia: Gabriela Ribeiro

Sonoplastia: Flavio Kotty

Seleção Musical: Mauro Felix

Iluminação: Flavio Kotty

Maquiagem: O Grupo

Produção: O Grupo

Operador De Som: Flavio Kotty

Operador De Luz: Flavio Kotty

Contra-Regra: Wenilson Moraes 


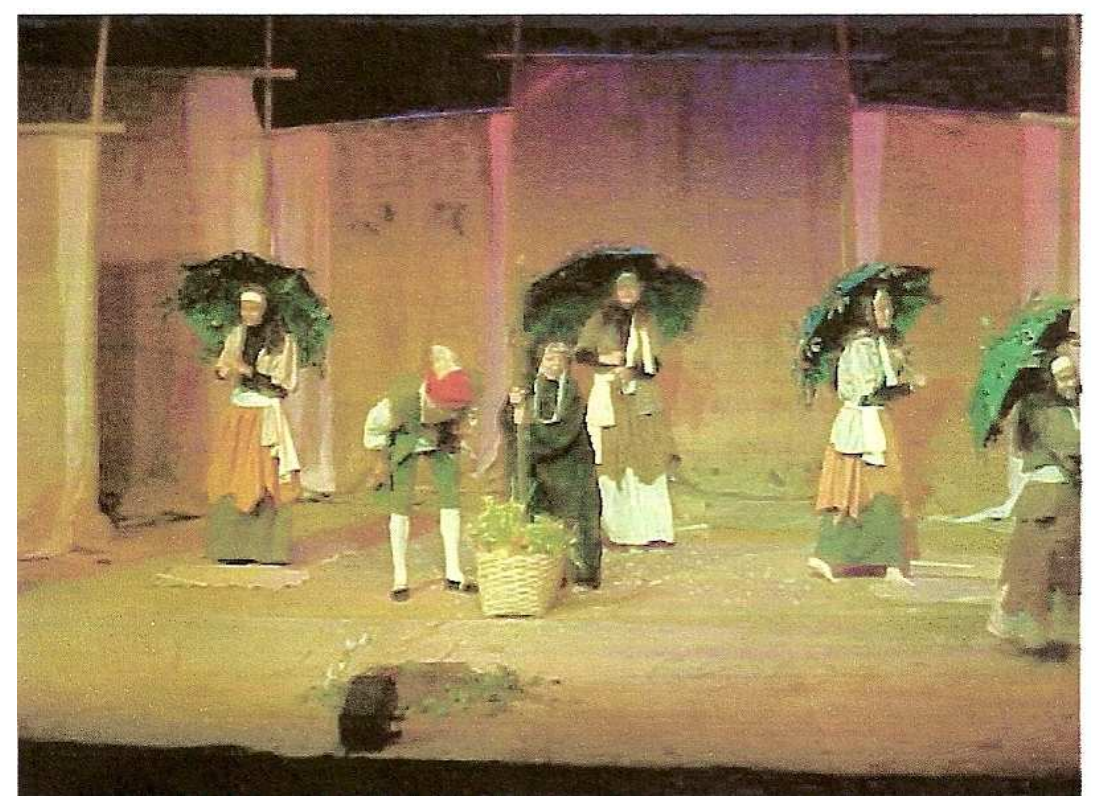

A LENDA DA VELHA DA FLORESTA

Sem dúvida, um espetáculo que não colocava em discussão o resultado final, era belíssimo, plasticamente e acontecia o fenômeno teatral, o diretor Reginaldo Galhardo, colocava em cena crianças e adolescentes, oriundos de diversas partes da região da cidade, que parece ser a pequena Paraguaçu Paulista. Sempre com seu jeito humilde, expôs nos debates as dificuldades que encontrava para realizar seus trabalhos. Seu grupo era imenso e tinha uma fidelidade muito grande com o diretor que também era professor da escola em que desenvolvia o trabalho. O que não ficava muito bem claro era o processo de trabalho, que desenvolvia, pois tudo que lhe era questionado sempre se colocava como se estivesse fazendo por autodidatismo, o que me deixa muito em dúvida na questão, do resultado final e o mecanismo processual. 
Quarta $18 / 09$

\section{CATEGORIA INFANTIL}

\section{A LENDA DA VELHA DA FLORESTA}

\section{RELEASE}

Segundo o povo contador, num antigo reinado, o rei resolve partilhar seu reino entre suas três filhas, reservando as melhores partes àquelas que the demonstrassem maior amor e afeição.

Descontente com a declaração da princesa menor, toma a desastrosas decisão de expulsá-la do reino, abandonando-a nos confins da florestas.

Com a razão recobrada e tomado de arrependimento, ordena aos guardas que tragam-na de volta, porém, é ai que o espetáculo nos leva pelas trilhas da magia e da emoção ao encontro de momento repletos de mistério e beleza.

\section{DADOS}

Espetáculo: A Lenda da Velha Autor: Reginaldo Galhardo

Grupo: Grupo Teatral "Escola Maria Angela" Escola: E.E. Profa. Maria Angela Batista Dias Cidade: Paraguaçu Paulista

\section{ELENCO}

Francine Soares Bezerra: Contadora Pablo Antonio R. Matta: Reizinho Pamela F.Zanluchi: Rainhazina Roberta Ap. Durigan: Princesinha 1 Michele Canevari: Princesinha 2 Tamires C. de Oliveira: Princesinha 3 Érique Soares Bezerra: Fidalguinho João Ricardo B. Francisco: Guardinha 1 Cláudio Corrêa: Guardinha 2 Roberta Ap. Durigan: Servinha 1 Michele Canevari: Servinha 2 Samira Soares de Moura: Velha Da Floresta Nayara Santos Aniceto: Pastora Ediney Bueno: Rei Simone Soares de Moura: Rainha Adriana Ap. Ferreira Ribeiro: Princesa 1 Isabelli Maia: Princesa 2 Nayara Santos Aniceto: Princesa 3 Arlindo Canato Filho: Fidalgo Luis Henrique B. Francisco: Guarda 1 Claudinei da Silva Menezes: Guarda 2 Jaqueline da Silva Soares: Serva
Pâmela Falbo: Mãe Das Crianças Jaqueline da Silva Soares: Criança 1 Thalita Cristina da Costa: Criança 2 Bruna Aparecida Silva: Ganso 1 Vanessa Martins Silva Braz: Ganso 2 Daniela Baptista Marques: Ganso 3 Thaís da Silva Alcântara: Ganso 4 Tatyany Martins da Motta: Ganso 5 Daniela Campos: Ganso 6

Patrícia A. Ribeiro: Coro - Menina 1 Priscila Aparecida Rita: Coro - Menina 2

Renata Maria Pilan: Coro - Menina 3

Tamiris de Almeida: Coro - Menina 4

Camila Azevedo de Melo: Coro - Menina 5

FICHA TÉCNICA E ARTÍSTICA

Diretor Do Espetáculo: Reginaldo Galhardo Figurino: Grupo

Cenografia: Grupo

Sonoplastia: Evandro G. Pedroso Iluminação: Mário Lúcio Florêncio Maquiagem: Nilza Guerino de Lima Produção:

Operador de Som:

Operador de Luz:

Contra-Regra: Adriano Ramos Stern e

Alessandro Antonio Gomes Goulart 


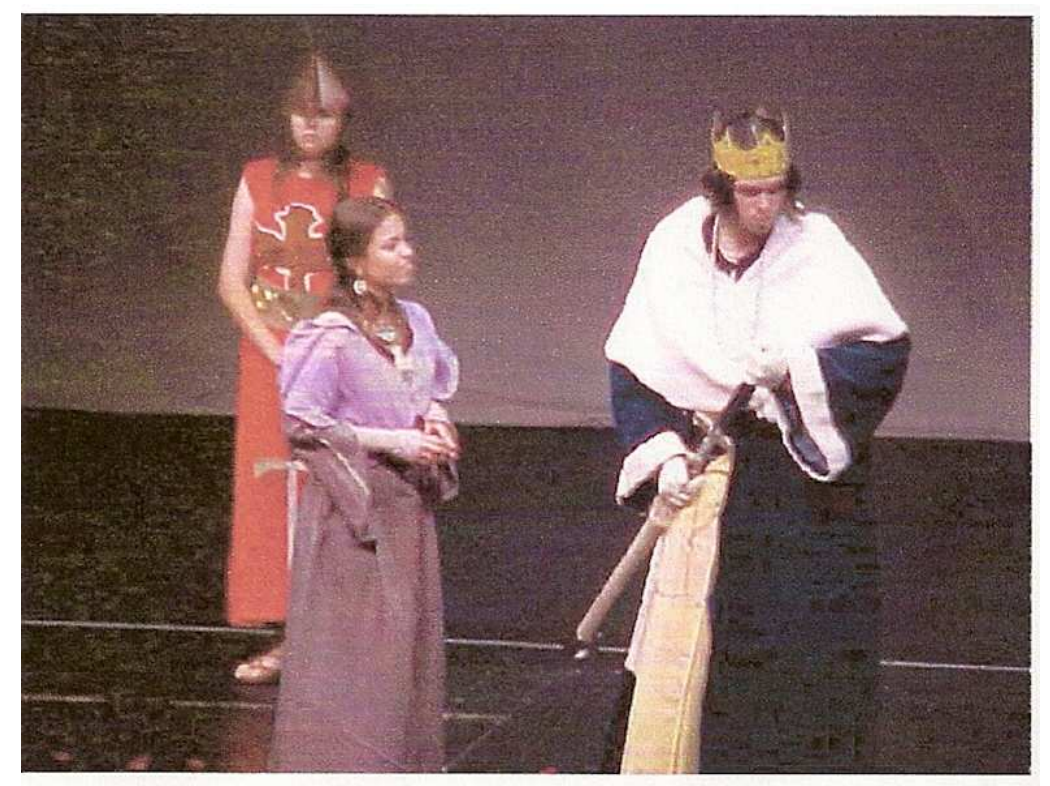

DANÇA DOS ESPELHOS

Este foi o espetáculo que mais me fez pensar naquele momento e sempre me leva a grandes reflexões. Quando o assisti no palco, perguntavame como existiam tantos equívocos em uma só montagem. Os atores-alunos pareciam ter medo do que estavam fazendo, era um desfile de figurinos, e coreografias interminável, chegou ao absurdo de colocar em cena crianças de 11 a 12 anos lutando com espadas reais. Quando se iniciou o debate, tudo foi questionado e é claro que começou se apontar o que já era de se esperar, o diretor Wanderley Cameosso, era um ídolo para aqueles alunos que tinha por referência aquilo como teatro. $O$ processo de montagem e trabalho era totalmente questionável. Ele preparou o trabalho para o festival e nada mais. Mas o que também me surpreendeu é que tinha pais envolvidos, o que é natural, e não conseguiam perceber qual a relação que estava se dando dentro do grupo. Também fui verificar sobre o grupo na escola, via telefone, e fui informado que depois desta montagem, o grupo se desfez e não sabiam por onde andava o professor. 


\section{CATEGORIA ADULTO}

\section{RELEASE}

\section{DANÇA DOS ESPELHOS}

Num tempo em que se perde na história, dois reinos separados por antigos rancores lutaı entre si. A guerra os mantém em atividade constante, mas também, extenuante. Durant uma dessas batalhas, uma conspiração militar coloca em perigo os dois reinos com o rapł da princesa Aralim.

Por outro lado, antigas lendas afirmam que ambos os reis teriam uma origem comum, $c$ mesmo sangue, o que perturba Saramelek, a conselheira de Melcebiades. Infiltrada n Reino de Angkor a Sitoniana, como é conhecida, incita as mais sangrentas batalha desgastantes para ambos os lados, seus antigos e ocultos rivais. No outro reino, Amele conselheira de T.Khar tenta impedir esses exaustivos confrontos, enfrentando assim, sL velha inimiga. Magia, fantasia, realidade e dança é o que oferece "Dança dos Espelhos um teatro expressionista que envolve 30 pessoas entre atores, atrizes e técnico.

\begin{tabular}{|c|c|c|c|}
\hline DADOS & Feiticeira Tamara & & Iara: Guerreira \\
\hline Espetáculo : Dar & SJoseane dos Santos: & Cristiane Pâmela: & Fernando S. Reis: \\
\hline Espelhos & Abertura, Guerreira, & Conselheira Amelek & Guerreiro, Loucura \\
\hline Autor: Vanderley & Morcego Daélix, & Ives: Guerrei- & Alisson Dominicali: \\
\hline Carneosso & Coreografia: Africana & afia: & Gue \\
\hline Grupo: Cia Teatral & de Abreu: & Afri & Piovezan: \\
\hline Aym & rreira, & sta: & \\
\hline Escola: E.E. "Profa & Gár & $\begin{array}{l}\text { al Krajthor, } \\
\text { ina da Serp }\end{array}$ & Moura: \\
\hline $\begin{array}{l}\text { Joceny Villela Curado" } \\
\text { Cidade: Jundiaí }\end{array}$ & $\begin{array}{l}\text { Cor } \\
\text { Luc }\end{array}$ & a do Espelho & Gu \\
\hline & Abe & ra: & $G$ \\
\hline ELENCO & fias: Loucura & a, Coreografia: & FICHA TÉCNICA E \\
\hline Nayara Vian: Musa da & e Af & & SIICA \\
\hline $\begin{array}{l}\text { Justiça, Guerreira, } \\
\text { Morcego Trilion Coreo- }\end{array}$ & Mic & s: & Do Espetácu \\
\hline $\begin{array}{l}\text { Morcego Trilion Coreo- } \\
\text { grafia Africana }\end{array}$ & $\begin{array}{l}\text { Ueira, } \\
\text { Loucu }\end{array}$ & Loucura e Africana & ${ }^{5}$ Ic \\
\hline Karina Thais Dias: & ras & Marques: & $\mathrm{C}$ \\
\hline $\begin{array}{l}\text { ura, Coreografia: } \\
\text { ura }\end{array}$ & Raq & ra, Morcego & $\mathrm{Ca}$ \\
\hline $\begin{array}{l}\text { Ira } \\
\text { Paula }\end{array}$ & Abe & n & $\mathrm{Ce}$ \\
\hline $\begin{array}{l}\text { Ana Paula: Abertura, } \\
\text { Princesa Aralim }\end{array}$ & $\begin{array}{l}\text { Cor } \\
\text { Due }\end{array}$ & & \\
\hline Bruna Negrine: Abertu & Lúcia Gomes: & : & Va \\
\hline $\begin{array}{l}\text { eneral Thalis, } \\
\text { grafias: Louc }\end{array}$ & A & & klli \\
\hline $\begin{array}{l}\text { grafia } \\
\text { רa }\end{array}$ & $E$ & & to \\
\hline $\begin{array}{l}\text { Afric } \\
\text { Dai: }\end{array}$ & , Feiticeira, & , Coreogra- & V \\
\hline Daia & & & gem: O Grup \\
\hline ra, & ton Lima: & Lopes: & ção: O Grupo \\
\hline adez & Abe & a, Morcego & Operador De Som: \\
\hline & & z, Coreografia & Cesar Simões da Sil \\
\hline eogr & & & De Luz. \\
\hline Lou & a Chinedon, & & e Almeida \\
\hline & Príncipe Liornay & & $\mathrm{Cc}$ \\
\hline $\begin{array}{l}\text { Deolinda Ribeiro: } \\
\text { Abertura, Guerreira, }\end{array}$ & $\begin{array}{l}\text { Fernando H. Belboni: } \\
\text { Rei T. Khar }\end{array}$ & $\begin{array}{l}\text { as: Loucura e Africal } \\
\text { Roberto V. Júnior: }\end{array}$ & \\
\hline
\end{tabular}




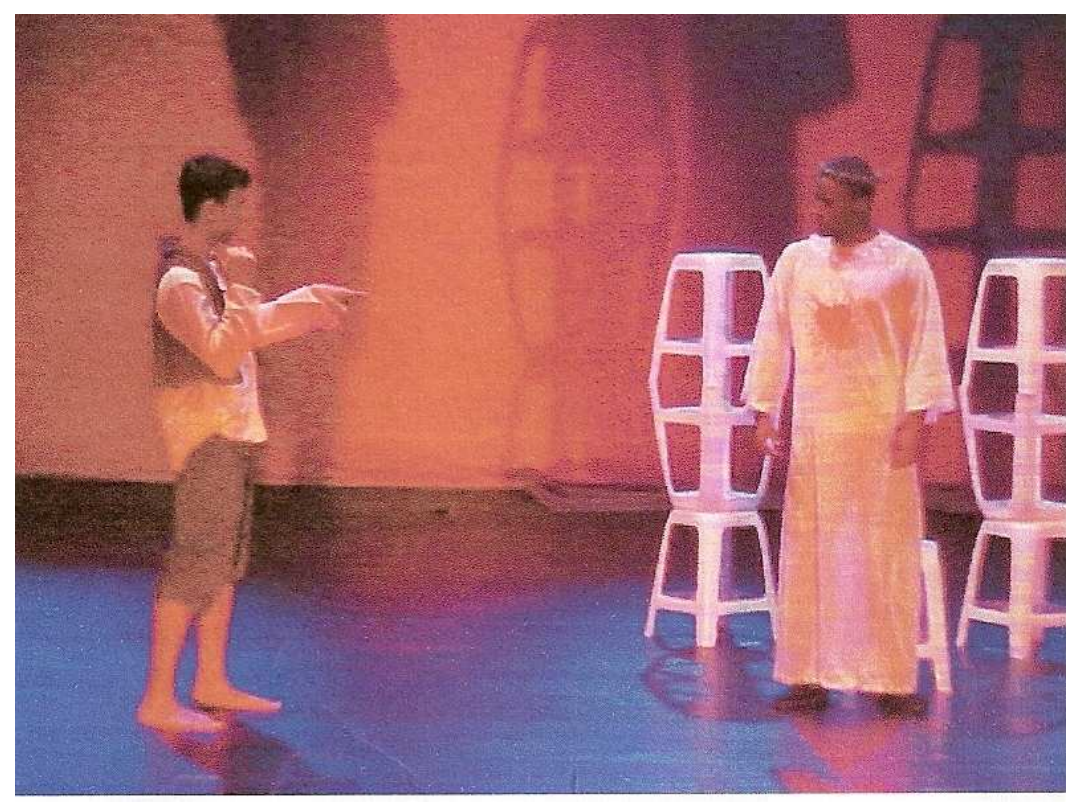

SOLTANDO O VERBO

O grupo de teatro Família Matula de Teatro, dirigido pelo professor de Português, Rubens Espírito Santo, estava apresentando seu segundo espetáculo no festival, como já foi falado no espetáculo $O$ caixeiro da taverna, na história de processo de trabalho é o mesmo, pois o mesmo grupo fez as duas montagens. 
Quinta 19/09

\section{CATEGORIA INFANTIL}

\section{SOLTANDO O VERBO}

\section{RELEASE}

Soltanto o verbo de Zecarlos de Andrade, como o próprio autor define, é um exercício de teatro, que proporciona inúmeras formas para encenação e para os atores, uma grande oportunidade para aprender a interpretar. O texto tem início com a criação do mundo pelo Verbo, segue com as diversas formas de se comunicar e a necessidade de registrar o que se diz, sendo criada a Literatura. Dentro da Literatura os gêneros literários e por fim as diversas Escolas Literárias e seus escritores mais expressivos. O público é levado a um passeio pela Literatura, identifica e relembra obras que já viu ou se delicia com outras que ainda não havia escutado. Em uma hora de apresentação tem-se a sensação de estar participando de uma aula e de fato para muitos, o que acontece é isso mesmo. O espetáculo consegue agradar a todos; crianças, jovens e adultos; prende a atenção, diverte e educa. Fundamental também é o valor e o incentivo que o texto dá à leitura e ao conhecimento de nossos autores e nossa literatura, num país tão carente de leitores.

\section{DADOS}

Espetáculo: Soltando o Verbo Autor: Zecarlos de Andrade Grupo: Família Matula de Teatro Escola: E.E. Prof. Lauro Sanchez Cidade: Sorocaba

\section{ELENCO}

Alessandra Fernandes Prandi Francisco Antonio Neto Gislene Freitas Pereira Diego Alves Ferreira Miranda Joyce Angelina Caus Luis Fernando Aires Mônica Messias Silva

\section{FICHA TÉCNICA E ARTÍSTICA} Diretor Do Espetáculo: Rubens Espirito Santo Figurino: O Grupo Cenografia: Francisco Antonio Neto Sonoplastia: Rubens Espirito Santo Iluminação: Mônica Messias Maquiagem: $O$ Grupo Produção: E.E. "Prof. Lauro Sanchez" e Grupo

Operador De Som: Rubens Espirito Santo

Operador De Luz: Jairo Leme Contra-Regra: Marilene Fernandes 


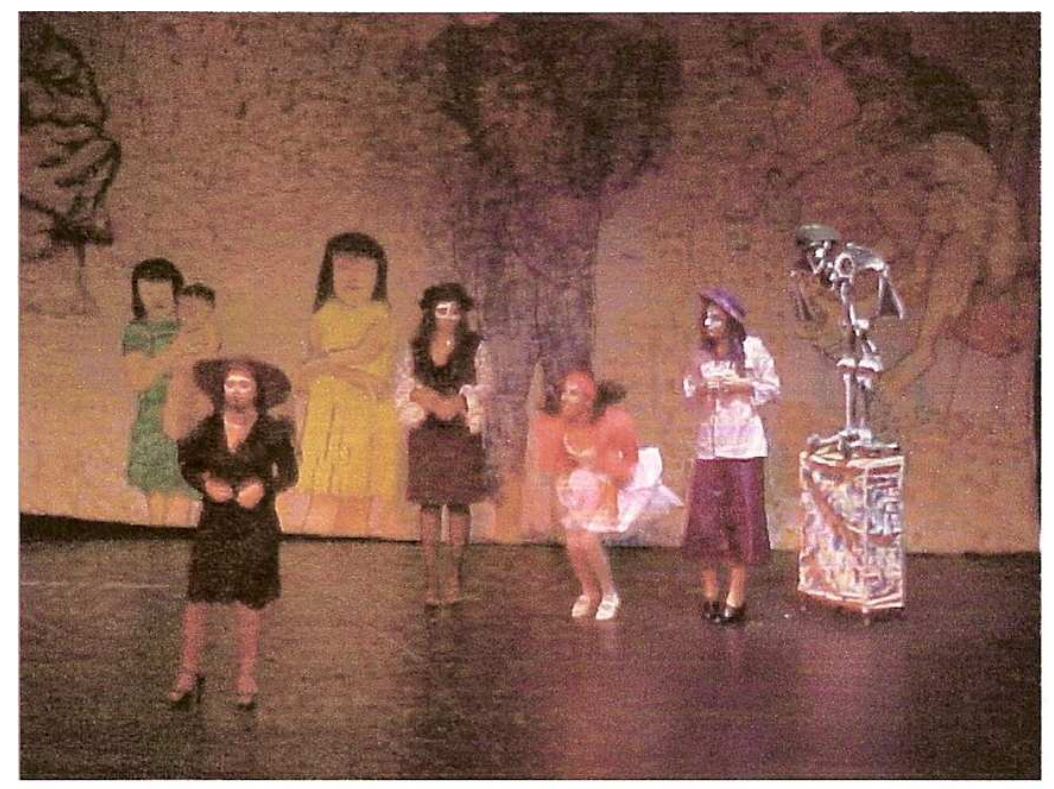

VIÚVA, PORÉM, HONESTA!

Um dos espetáculos de Nélson Rodrigues, em que realmente se percebia o universo rodrigueano. Em cena, o processo de trabalho era visível, pois além de uma direção impecável de João Carlos Luz, a escola Modesto Tavares de Lima, tinha uma tradição em apoiar os grupos de teatro. Era uma união perfeita do corpo docente, alunos e comunidade, por essa razão, o trabalho do teatro estudantil se estabelecia naquela escola. 


\section{CATEGORIA ADULTO}

\section{"VIÚVA, PORÉM HONESTA!"}

\section{RELEASE}

Trata-se da comédia: "Viúva, porém honesta!", do consagrado autor teatral Nelson Rodrigues O texto narra em tom de farsa as desventuras do Dr. J.B. de Albuquerque Guimarães chefe de um influente jornal que apesar de todo o seu poderio não consegue fazer sua filh Ivonete, largar uma viúvez de um marido de reputação duvidosa. O detalhe é que té casamento surgiu de uma falsa gravidez. Para tentar convencer a filha, o Dr. J.B. convoc um grupo de charlatões (um otorrinolaringologista, um psicanalista e uma ex-cocote) par analisar e dar solução do problema

Em meio a esse desfile de personagens insólitos surge o Diabo da Fonseca, figura surré que terá importância crucial para o desfecho surpreendente da trama. O espetáculo Viúve porém honesta! tem um elenco de 15 atores, sendo que toda a produção reúne um total d

28 pessoas.

\section{DADOS}

Espetáculo: Viúva, Porém Honesta! Autor: Nelson Rodrigues - Adapatação: João Carlos Luz

Grupo: Grupo de Teatro "Em Cena Ação" Escola: E.E.P.S.G. Modesto Tavares de Lima

Cidade: Itapetininga

\section{ELENCO}

Paulo Sérgio Carriel: J.B. Josinei Rodrigues: Pardal

Maria das Graças Ribeiro dos Santos:

Madame Cricri

Luiz Miguel Batista Corrêa: Dr. Lupicinio

(Psicanalista)

Wilson de Aguiar Medeiros Oliveira: Dr.

Sanatorio (Otorrino)

Victor Hugo Rosa Gonzáles: Diabo Da

Fonseca

Rodrigo Tabajara da Silva Gomes:

Dorothy Dalton

Fernando da Silva Magalhães: $\mathrm{Dr}$.

Lambreta

Josiane de Fatima Santos: Ivonete (Viúva)

Luciana Barbosa de Freitas: Tia Assem-

bléia

Thais Fernanda Souto de A. Oliveira: Tia

Solteirona 1

Fernanda Aparecida Soares: Tia Solteiro- na 2

FICHA TÉCNICA E ARTÍSTICA

Diretor Do Espetáculo: João Carlos Luz

Figurino: Renata Carriel

Cenografia: Grupo Em Cena Ação

Sonoplastia: João Carlos Luz

Iluminação: Renata Carriel e João Carlos

Luz

Maquiagem: Paulo Carriel

Produção: Grupo de Teatro em Cena

Ação

Operador De Som: Mário Andrade

Operador De Luz: Renata Carriel

Contra-Regra: O Grupo em Cena Ação 


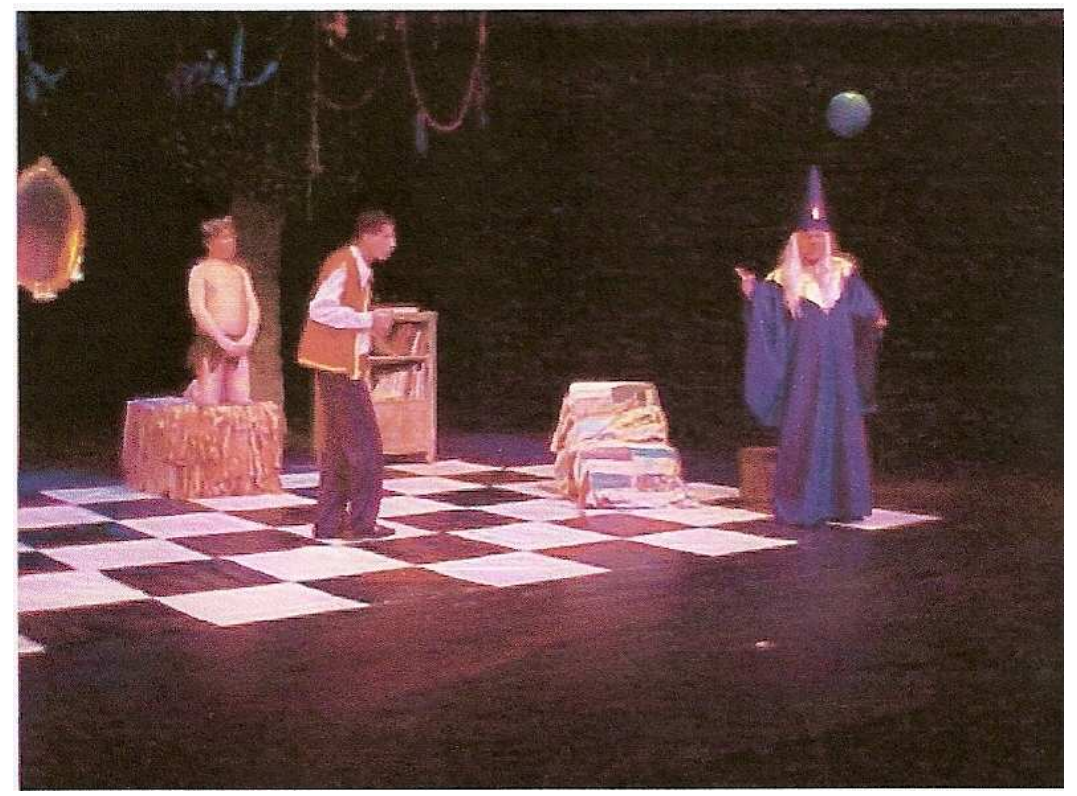

BEIJO, NÃO

Um espetáculo simples como a própria autora Tatiana Belinky, com uma direção impecável do diretor Júlio Carrara, durante o debate ficou muito claro o processo que o diretor desenvolvia dentro da escola e o apoio que recebia da comunidade, os alunos que tinham em media de 10 a 14 anos de idade tinha claramente o processo que era desenvolvido pelo diretor, que usava jogos em seu trabalho para a construção do espetáculo. 
Sexta $20 / 09$

\section{CATEGORIA INFANTIL}

"BEIJO, NÃO!".

\section{RELEASE}

Certo dia, um velho feiticeiro, de brincadeira, transformou um macaco num moço bonito $e$ simpático. E o mandou pelo mundo pedindo que voltasse dali a um ano e um dia, para ver no que a sua feitiçaria ia dar.

\section{DADOS}

Espetáculo: "Beijo, Não!"

Autor: Tatiana Belinky

Grupo : Companhia das Artes Dramáticas (Cad)

Escola: EE "Comendador Pereira Inácio" Cidade: Votorantim

\section{ELENCO}

Diego Francisco: Moço Quinzinho Hércules Soares: Coruja Urracunda Julio Carrara: Feiticeiro M erlinaldo Kátia Cezário: Moça Katita

Keila Cezário: Macaco
FICHA TÉCNICA E ARTÍSTICA

Diretor Do Espetáculo: Julio Carrara Assistente De Direção: Rafael Vieira Figurino: Julio Melo

Cenografia: Julio Carraro

Sonoplastia: Julio Carraro Músico: Rafael Felício Iluminação: Rafael Vieira Maquiagem: Eliane Ribeiro Produção: Julio Carraro Operador De Som: Julio Melo Operador De Luz: Rafael Vieira Contra-Regra: Andréia Munhoz Cenotécnica: Leandro Pineda, Pedro Soares, Bruna Soares, Mariana Teixeira 


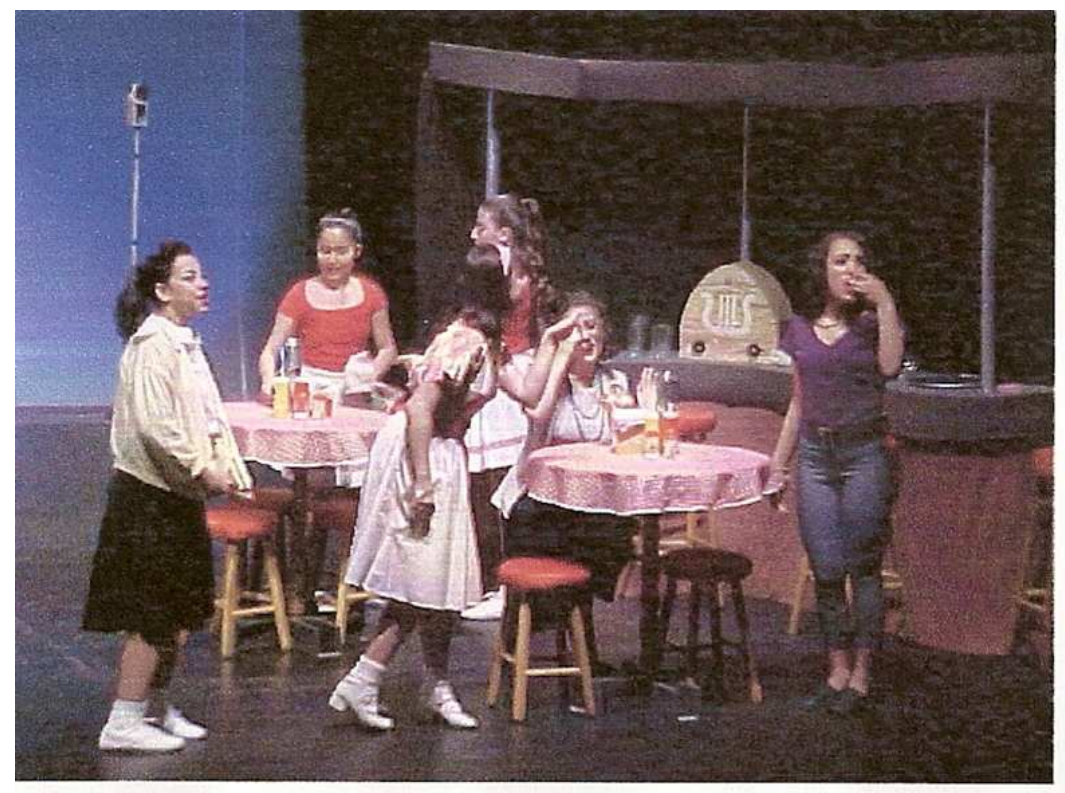

\section{GERAÇÃO COCA-COLA}

A professora de Biologia e diretora do espetáculo, Pámela Paz, embora desenvolva seu trabalho em escola particular, sua realidade não difere dos grupos que desenvolvem trabalhos em escola pública, também tem que fazer ensaios fora do horário de aula e que não atrapalhe o andamento da escola. Enfrentava ainda um pouco de preconceito com os temas a serem desenvolvidos uma vez que o colégio é mantido por padres. O processo de trabalho pela professora artista fica muito bem definido e quando vai para o palco o resultado é emocionante. É bom ver tantos alunos em cena com domínio, que só se pode obter a partir de processo muito bem elaborado e aplicado. E o grupo até hoje é comandado pela professora artista, e vem assiduamente participando do festival Sesi Sorocaba de teatro. 


\section{CATEGORIA ADULTO}

\section{GERAÇÃO COCA-COLA}

\section{RELEASE}

O espetáculo se passa no final da década de 50 e início de 60 , "quando os sonhos eran tão fortes e a felicidade parecia tão próxima. A lua era virgem, Hollywood em seu esplendor! A velocidade e a liberdade caminham juntas com a inocência e a loucura... Tantas garotas procuravam os seu Elvis...".

Neste espetáculo tentamos passar a realidade vivida por seis casais de jovens no final dc anos 50, a formação de "gangs", suas rivalidades, o encantamento do primeiro beijo, medo da gravidez indesejada, o flerte em sorveterias e o querer ter um futuro certo e Hollywood, o retrato do começo de uma virada no comportamento dos jovens da época e: conflito com as gerações anteriores.

Esta é a mais uma produção do Grupo "teen" de Teatro Santo Agostinho que tem com objetivo central despertar nos jovens o enorme potencial de revolucionar a vida com art cultura e momentos positivos.

\section{DADOS}

Espetáculo: Geração Coca-Cola Autor: Ronaldo Ciambroni

Grupo: Grupo "Teen" de Teatro Santo Agostinho

Escola: Colégio Santo Agostinho

Cidade: São Paulo

\section{ELENCO}

Analuê Borges: Garçonete 1

Andrea Harabari: Suzy

Camila Nastari: Nádia

Cristiane Lima: Dóris

Danilo Eugênio: Bob

Felipe Albert: Tony

Henrique Faria: Catraca

Inara Santos: Zizi

Juliana Feitosa: Lili

Mariana Novaski: Meg

Maurício Alonso: Dicky

Pablina Araújo: Garçonete 2

Thiago Larenas: Babalu

Yuri Saito: Ted
FICHA TÉCNICA E ARTÍSTICA

Diretor do Espetáculo: Pámela Paz e

Fábio Hilst

Diretor Musical: Rafael Righini

Trilha Sonora: Gilson Faria

Cenário: Gilson Faria

Figurino: Satie Nakachima e Rosa

Nogueira

Coreografia: Janaína Castro

Cenografia:

Sonoplastia:

lluminação:

Cabelo e Maquiagem: Lilian Luchesi Produção: Grupo Teatro Santo Agostinh، Operador de Som: Lílian Flôres e Fábio Hilst

Contra-Regra:

Equipe Técnica: Juliana Satie, Priscilla Kalil, Thays Nogueira, Eduardo Cavalheiro, Bruna Satiko, Daniella Faria

Fotos: Denise Tsonis

Administração: Adriano Souza

Pesquisa: Grupo Teen de Teatro Santo Agostinho 


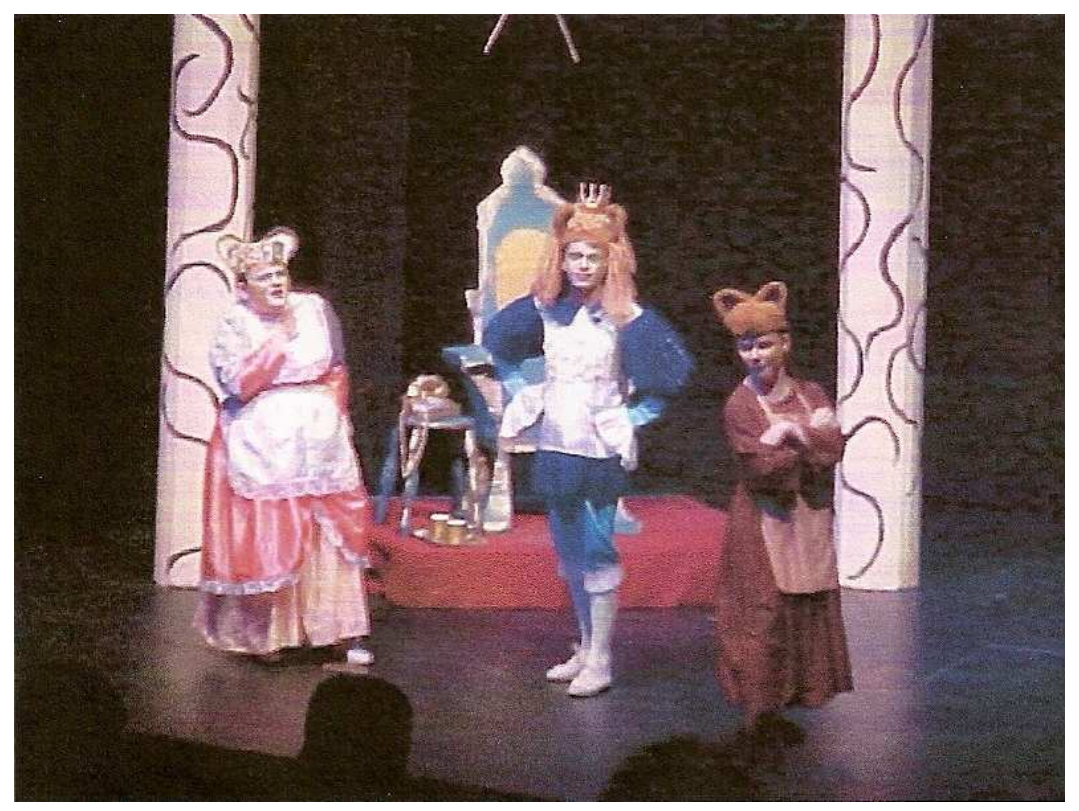

DONONÇA FAZ QUITUTES

Espetáculo convidado com minha direção Junior Mosko, em que procurei levar ao palco um espetáculo da criança para criança, com criança.

Dononça faz quitutes de Fabio Gaia, trabalhei com quatro atores um de $8,9,11$, e 13 anos. As crianças se dedicaram a esse trabalho durante quatro meses.

Este grupo originou-se de um trabalho desenvolvido em uma escola pública, onde fui voluntário para poder desenvolver esta pesquisa. O teatro da criança, pela criança e para criança, onde pude ter material para a finalização do Curso de Especialização em Teatro Educação, com orientação da Professora Doutora Ingrid Dormien Koudela na Universidade do Sagrado Coração de Bauru e, posteriormente, publicado. ${ }^{8}$

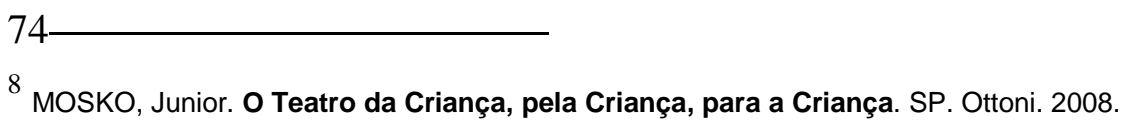




\section{Sábado 21/09}

\section{ESPETÁCULOS CONVIDADOS}

\section{DONONÇA FAZ QUITUTES}

\section{RELEASE}

A estória se passa num reino distante, onde há séculos já era proibido fazer "Bolo de Chocolate".

Mas Dononça uma simpática Sra. Onça, apaixonada pôr culinária, resolve fazer um bolo de chocolate em sua casa no meio da floresta, mas o Sr. Raposo, com seu grande focinho, de longe fareja o saboroso cheiro de bolo, e pôr ser mau caráter, resolve investigar e denunciar Dononça em rede de TV e qudno Rei Lé, proibido de comer bolo (por causa de uma forte dor de barriga), fica sabendo e mando sua secretária Hiena chamar a boa cozinheira para fazer um quitute para ele.

O repórter Raposo se interessa pelo bolo e rouba o confeito, sem saber que a boleira tinha feito dois bolos, um era com uma receita comum (que da dor de barriga) e o outro era feito com a receita especial de Dononça, mas como o primeiro bolo comum é roubado, a desgraça da dor de barriga caí sobre o enxerido Raposo.

O rei comeu o segundo bolo, por ser a receita especial de Dononça, não lhe da dor de barriga e ela é nomeada boleira oficial do rei, enquanto o Sr. Raposo, paga por seus erros gemendo de dor e sempre buscando um remédio para curá-lo.

\section{DADOS}

Espetáculo: Dononça faz Quitutes Autor: Fábio Gaia

\section{ELENCO}

Daniela Mosko: Dononça Angélica Albuquerque: Hiena Renato Machado: Raposo Rafael Nunes: Rei Lé
FICHA TÉCNICA E ARTÍSTICA

Diretor do Espetáculo: Junior Mosko Figurino: Marcos Antunes Cenografia: Marcos Antunes Sonoplastia: Lucilene Fernanda Iluminação: Andréa Paes Maquiagem: Marcos Antunes Produção Executiva: João Alfredo Operador de Som: Operador de Luz: Contra-Regra: 


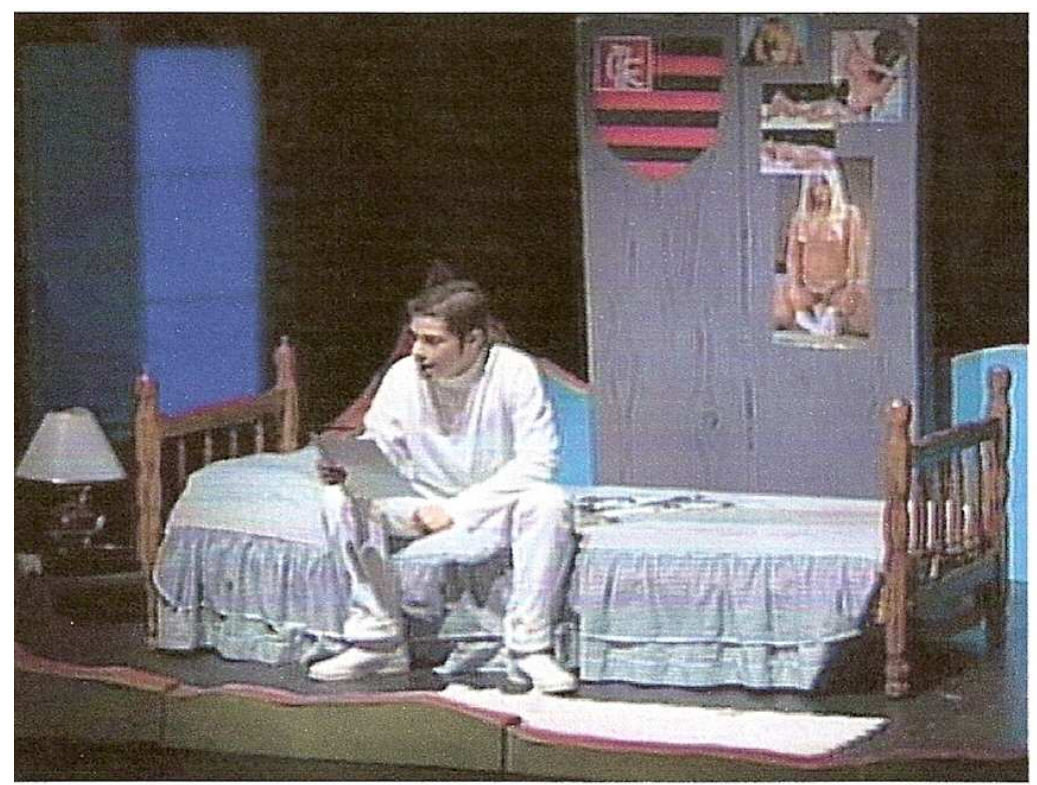

O CORDÃO UMBILICAL

Este espetáculo se apresentou como convidado no festival. Optei por levar este espetáculo como convidado, também por ter minha direção, e ser feito por adolescentes, foi minha primeira montagem pelo Núcleo de Artes Cênicas do Sesi Sorocaba. 


\section{O CORDÃO UMBILICAL}

\section{RELEASE}

O Cordão Umbilical, de Mário Prata é um texto consagrado pela crítica, que nos mostra através de uma linguagem simples e atual o dia-a-dia de quatro jovens que vivem na cidade maravilhosa, no Rio de Janeiro. Onde cada um deixa transparecer a sua vontad de vencer (cada um a sua maneira). No decorrer da Estórias os quatros jovens se junte sob o teto de um mesmo apartamento fazendo que a individualidade de cada um seja esquecida para viverem um todo.

O enfoque maior se dá sobre Kátia Porreta, uma prostituta, já com duas filhas e grávidi que sem onde morar pede abrigo a seu cliente, Didi, um estudante de medicina, que divide o apartamento fazendo que a individualidade de cada um seja esquecida para viverem um todo.

A princípio, o escritor Marcos não se dá muito com a prostituta, mas depois de uma longa e emocionante conversa se inspira em sua trágica história e começa contar em $\mathrm{s}$ livro toda a problemática de uma mãe solteira, que necessita da prostituição para sobre viver e para sustentar seus filhos.

\section{DADOS}

Espetáculo: O Cordão Umbilical Autor: Mário Prata

\section{ELENCO}

Tatiana Pelegri: Kátia Porreta

Didi: Felippe Moraes

Fernanda D'Almeida: Gladys Regina Willyams Ballov: Marco

Rafael Nunes: Voz de Pedro Leopoldo Voz de Dirce: Lucilene Fernanda

FICHA TÉCNICA E ARTÍSTICA

Diretor do Espetáculo: Junior Mosko Figurino: Marcos Antunes Neto Cenografia: Marcos Antunes Neto Sonoplastia: Lucilene Fernanda lluminação: Claudinei Rosa Maquiagem: Daniela Mosko Contra-Regra: Andréa Paes e Renato Machado

Apoio: Sandra Maria Moura 
PREMIAÇÃO CATEGORIA INFANTIL

\begin{tabular}{|c|c|c|c|c|c|}
\hline & $\begin{array}{l}\text { O RAPTO DAS } \\
\text { CEBOLINHAS }\end{array}$ & $\begin{array}{l}\text { FEITICOO DOS } \\
\text { DEUSES }\end{array}$ & $\begin{array}{l}\text { A LENDA DA } \\
\text { VELHA DA } \\
\text { FLORESTA }\end{array}$ & $\begin{array}{l}\text { SOLTANDO O } \\
\text { VERBO }\end{array}$ & BEIJO NÃO \\
\hline $\begin{array}{l}\text { ATOR } \\
\text { REVELAÇÃO }\end{array}$ & & MAURO FELIX & & $\begin{array}{c}\text { FRANCISCO } \\
\text { ANTÔNIO NETO }\end{array}$ & \\
\hline $\begin{array}{l}\text { ATRIZ } \\
\text { REVELAÇÃO }\end{array}$ & & & & & KEILA CEZÁRIO \\
\hline $\begin{array}{l}\text { COADJUVANTE } \\
\text { MASCULINO }\end{array}$ & & & $\begin{array}{l}\text { PABLO A. R. } \\
\text { MATTA }\end{array}$ & & \\
\hline $\begin{array}{l}\text { COADJUVANTE } \\
\text { FEMININO }\end{array}$ & $\begin{array}{l}\text { JAQUELINE } \\
\text { CARDOSO }\end{array}$ & & & & \\
\hline CENOGRAFIA & $\begin{array}{c}\text { THIAGO LEITE / } \\
\text { JOÃO } \\
\text { ARMANDO } \\
\text { FABRO }\end{array}$ & & & & \\
\hline ILUMINAÇÃO & $\begin{array}{l}\text { ANDRÉ LUIZ } \\
\text { CAMARGO }\end{array}$ & & & & \\
\hline FIGURINO & $\begin{array}{l}\text { SÉRIO SILVA } \\
\text { FRANCO }\end{array}$ & & & & \\
\hline MAQUIAGEM & & & $\begin{array}{l}\text { NILSA GUERINO } \\
\text { DE LIMA }\end{array}$ & & \\
\hline SONOPLASTIA & & & & & $\begin{array}{c}\text { JULIO } \\
\text { CARRARA }\end{array}$ \\
\hline DIREÇÃO & & & $\begin{array}{l}\text { REGINALDO } \\
\text { GALHARDO }\end{array}$ & & \\
\hline MELHOR ATOR & $\begin{array}{c}\text { JOÃO } \\
\text { ARMANDO } \\
\text { FABRO }\end{array}$ & & & & \\
\hline AMELHOR ATRIZ & & & $\begin{array}{c}\text { SAMIRA } \\
\text { SOARES DE } \\
\text { LIMA }\end{array}$ & & \\
\hline $\begin{array}{l}\text { MELHOR } \\
\text { ESPETÁCULO }\end{array}$ & & & $\begin{array}{l}\text { A LENDA DA } \\
\text { VELHA DA } \\
\text { FLORESTA }\end{array}$ & & \\
\hline
\end{tabular}


PREMIAÇÃO CATEGORIA ADULTO

\begin{tabular}{|c|c|c|c|c|c|}
\hline & $\begin{array}{c}\text { O CAIXEIRO DA } \\
\text { TAVERNA }\end{array}$ & $\begin{array}{l}\text { QUASE VAN } \\
\text { GOHG }\end{array}$ & $\begin{array}{l}\text { DANÇA DOS } \\
\text { ESPELHOS }\end{array}$ & $\begin{array}{l}\text { VIÚVA, PORÉM } \\
\text { HONESTA }\end{array}$ & $\begin{array}{c}\text { GERAÇÃO } \\
\text { COCA-COLA }\end{array}$ \\
\hline $\begin{array}{l}\text { ATOR } \\
\text { REVELAÇÃO }\end{array}$ & & MAURO FELIX & & & \\
\hline $\begin{array}{l}\text { ATRIZ } \\
\text { REVELAÇÃO }\end{array}$ & & & & $\begin{array}{l}\text { FERNANDA } \\
\text { SOARES }\end{array}$ & \\
\hline $\begin{array}{l}\text { COADJUVANTE } \\
\text { MASCULINO }\end{array}$ & $\begin{array}{c}\text { LUIZ } \\
\text { FERNANDO } \\
\text { AIRES }\end{array}$ & & & & \\
\hline $\begin{array}{l}\text { COADJUVANTE } \\
\text { FEMININO }\end{array}$ & & & & & INARA SANTOS \\
\hline CENOGRAFIA & & & & & GILSON FARIA \\
\hline ILUMINAÇÃO & & & & $\begin{array}{c}\text { RENATA } \\
\text { CARRIEL/JOÃO } \\
\text { CARLOS LUS }\end{array}$ & \\
\hline FIGURINO & & & & & $\begin{array}{c}\text { SATIKO } \\
\text { MAKACHUMA/ } \\
\text { ROSA } \\
\text { NOGUEIRA }\end{array}$ \\
\hline MAQUIAGEM & & & & $\begin{array}{l}\text { PAULO } \\
\text { CARRIEL }\end{array}$ & \\
\hline SONOPLASTIA & & & & & LILIAM FLORES \\
\hline DIREÇÃO & & & & $\begin{array}{c}\text { JOÃO CARLOS } \\
\text { LUZ }\end{array}$ & \\
\hline MELHOR ATOR & & & & $\begin{array}{l}\text { PAULO SERGIO } \\
\text { CARRIEL }\end{array}$ & \\
\hline AMELHOR ATRIZ & & & & & $\begin{array}{l}\text { CRISTIANE } \\
\text { LIMA }\end{array}$ \\
\hline $\begin{array}{l}\text { MELHOR } \\
\text { ESPETÁCULO }\end{array}$ & & & & $\begin{array}{l}\text { VIÚVA PORÉM } \\
\text { HONESTA }\end{array}$ & \\
\hline
\end{tabular}



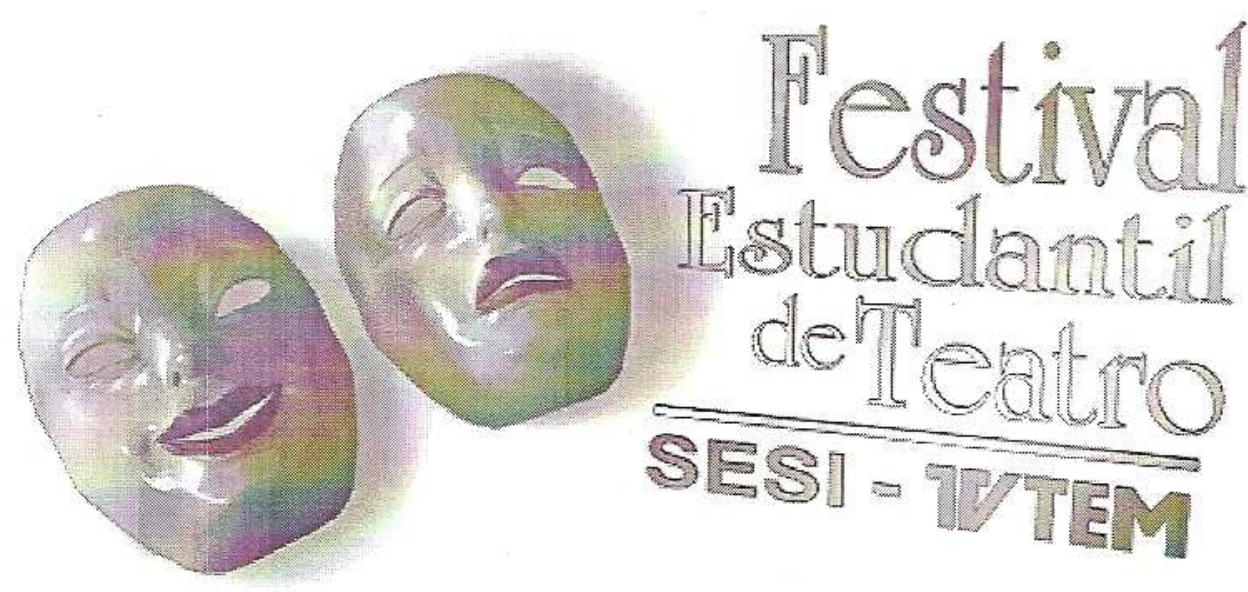

\section{SOROCABA}
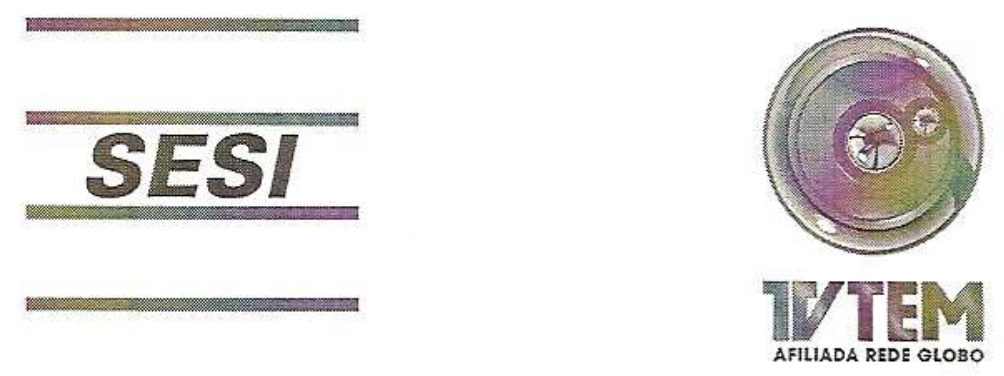

Apoio:
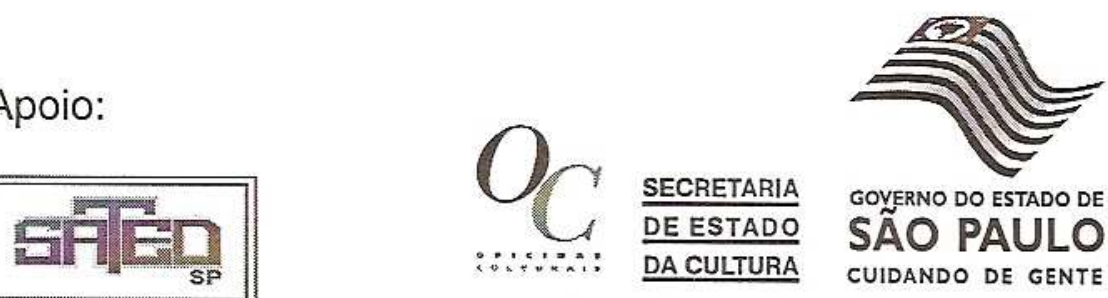

2 Festival Estudantil de Teatro SESI - TV Tem 
O $2^{\circ}$ Festival Estudantil de Teatro SESI TV TEM aconteceu de 22 a 27 de setembro de 2008, teve como jurados Claudia Dalla Verde ${ }^{9}$, Marly Bonome $^{10}$ e Fátima Campidelli ${ }^{11}$.

Para este festival ainda contávamos com a parceria da TV Tem (anteriormente chamada de TV Aliança), afiliada a Rede Globo, com apoio do SATED/SP e Oficina Cultural Grande Otelo, ainda com poucos recursos o SESI ficando responsável pelo alojamento e alimentação dos jurados o Sindicato dos Artistas, com o pagamento dos cachês dos Especialistas e a Oficina Cultural com o apoio logístico.

Já um pouco mais estruturado e com os objetivos mais claros, o festival transcorreu dentro de um ambiente de normalidade. Em um dos debates, uma das especialistas coloca em cheque um grupo estudantil de teatro, da cidade de Mogi das Cruzes, onde a diretora do espetáculo era uma garota de 15 anos e toda a equipe e elenco transitava pela idade de 10 a 16 anos. O espetáculo se chamava $O$ Baile dos Sonhos, o texto foi criado a partir do que eles chamavam de jogos e era formado por 24 jovens. Tudo tinha a ver com a realidade vivenciada por aqueles jovens. Durante a exposição do grupo no debate, uma das especialistas, que é dramaturga, não levou em consideração o processo de trabalho e a pesquisa realizada pelos alunos e muito menos que se tratava de um teatro de estudantes, feito apenas por estudantes. Desde 0 início, eles deixaram bem claro que não conseguiram nenhum professor para orientá-los, mas estavam ali para poder se alimentar de informações. Aquele grupo maravilhoso de jovens da periferia de Mogi das Cruzes, com um

\footnotetext{
81

${ }^{9}$ Dramaturga, crítica e professora de teatro-educação na Escola de Comunicação e Artes, ECA, da USP, Roteirista dos Programas: Ratimbum, Mundo da Lua, Castelo Ratimbum, XTudo, Cocoricó (todos da TV Cultura, SP); Disney Club e Disney CRUJ (SBT,SP), Turma do Gueto (Rede Record,SP).

${ }^{10}$ Bacharel em Teatro pela ECA/USP, Mestre em Teatro pela ECA. Coordenadora do Curso de Artes Cênicas da USC, docente das disciplinas: Teatro Educação, Cenografia, Técnicas Teatrais. Diretora teatral do Teatro Universitário Veritas da USC, em Bauru. Participou como membro do júri de diversos Festivais de Teatro pela Secretaria de Estado da Cultura de São Paulo onde trabalhou durante dez anos.

${ }^{11}$ Especializada em Teatro e Dança pela USP. Foi integrante do Teatro Vento Forte, onde atuou nos espetáculos: Lenços e Ventos, A Tempestade, Choro Lorca, entre outros. Participou dos Festivais Internacionais no Peru, na Argentina, em Cuba. E Também no festival de Juvelina, em Madri. Ė orientadora do NAC do Sesi há 9 anos.
} 
espetáculo sofrível, tinha muito claro o processo que realizou. A especialista não titubeou e abriu o seu discurso falando "- o que vocês fazem não é teatro, o espetáculo de vocês é muito ruim" e assim ela prosseguiu o seu discurso, digo discurso porque jamais poderia entender estas colocações como uma reflexão de um trabalho de jovens para jovens e que estavam participando de um festival estudantil.

Fico até hoje indagando e procurando uma resposta para tal avaliação pergunto: Por que, não levar em consideração o processo do trabalho? Por que não entender que era um espetáculo de jovens para jovens? Por que não entender que estamos falando sobre festival estudantil? Cabe assinalar que muitos teóricos e diretores de teatro dentro de seu ofício empregariam talvez este discurso, mas quando se leva em consideração apenas os elementos artísticos, mas estamos falando da expressão teatral, o que prova que a consciência é algo real entre os que se ocupam do espetáculo. Isso também confirma a necessidade de que o festival estudantil tem de oferecer a reflexão sobre os espetáculos ali apresentados. Como dizer que a palavra não estava presente neste espetáculo apenas porque ele tinha problemas de estrutura dramática.

Observo que a especialista em questão deveria apontar caminhos para ao grupo e não colocá-los em uma situação de exposição vexaminosa como assim foi feito. Também fiquei surpreso com os demais especialistas que podiam contrapor, mas que apenas endossaram de maneira mais amena e ressaltaram que o grupo era bonitinho, engraçadinho. Este questionamento me leva a refletir cada vez mais sobre o resultado final, ou seja, o próprio espetáculo, quando estamos falando de festival estudantil. Ressalta ainda que o artista nasce experimentando e depois deve buscar alicerce na teoria, mas é inconcebível que grupos como este encerrem sua trajetória desta maneira, como foi o que aconteceu com aquele grandioso grupo, sinto-me impotente perante tal situação.

$\mathrm{Na}$ finalização do debate, pedi a palavra e questionei os três especialistas, fugindo das regras de curador, coloquei-me e procurei mostrar para o grupo qual a importância do trabalho realizado por eles, mas percebi na expressão de cada um que jamais este grupo retomaria o trabalho. 
Há quatro anos, encontrei um dos integrantes, na cidade de são Paulo, que veio conversar comigo, referiu-se à situação vivida no festival e percebi que da mesma maneira que o festival fecunda e dissemina as Artes Cênicas, o mal especialista faz o papel inverso, pois nenhum daqueles jovens continuou a desenvolver $\mathrm{o}$ trabalho artístico $\mathrm{e}$, infelizmente, voltaram para as ruas. Pergunto onde está a importância da dramaturgia, quando falamos de um festival voltado para alunos, professores artistas e especialistas que refletem o processo jamais pode ultrapassar o resultado final. 


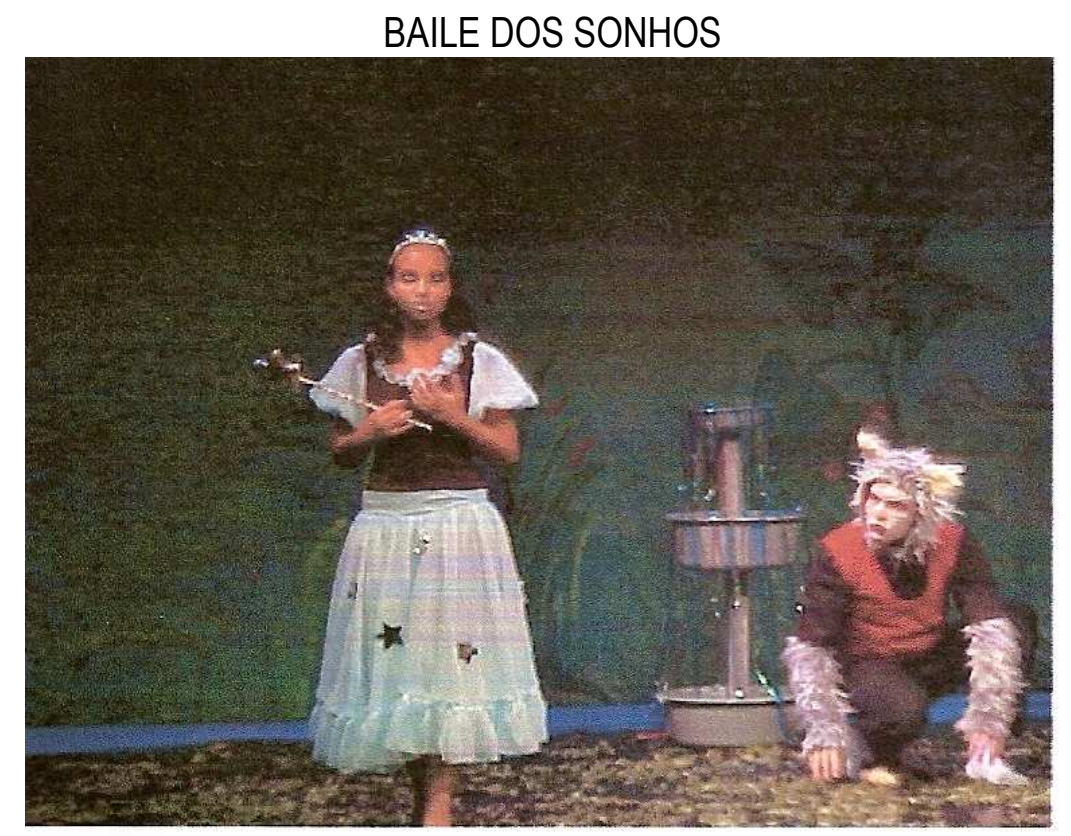

Autor: Criação coletiva

Grupo: Tertúlia

Escola: EE Prof ${ }^{a}$ Laurinda Cardoso de Mello Freire

Cidade: Mogi das Cruzes

O espetáculo O Baile dos Sonhos de criação do próprio grupo, embora tenha sido alvo de discussão no debate, considero que o espetáculo era o resultado de um grande processo de pesquisa e trabalho daqueles alunos que, mesmo sem orientação técnica, chegaram a surpreender pelo trabalho realizado no palco. O figurino era adequado, a montagem e sonoplastia feita de maneira precária, mas autêntica e a cenografia surpreendeu pelos pontos de acertos e não continha um objeto sequer decorativo. 
Release

O que é felicidade? Um carro importado, muito dinheiro ou talvez um príncipe encantado? Muitas pessoas buscam prosperidade, bens materiais e sonhos utópicos, geralmente, influenciadas por uma sociedade que se diz progressiva e realista. Porém, esquecemo-nos de que muitas vezes, a alegria de viver está na simplicidade das coisas. Assim é Luiza. Uma adolescente que simplesmente procura ser feliz. Baile dos Sonhos faz uma reflexão de forma cômica e divertida dos anseios humanos, penetrando num mundo que, simbolicamente, espelha os conflitos, desejos e esperanças da nossa mente. Para os adultos uma boa oportunidade para resgatar o espírito infantil e para as crianças, uma doce opção de entretenimento que enfatiza o valor da amizade e a importância de sonhar.

\section{FICHA TÉCNICA E ARTÍSTICA}

Diretor do espetáculo: Esther de Almeida Marcondes

Produção: Felipe da Silva, Vinícius Riqueto e Luciana da Silva

Figurino: Juliana de Paula Benevides Cenografia: Vinícius Riqueto de Operador de som: Thiago Henrique Martinez e Érica Akemi Fujiuara Oliveira

Sonoplastia: Luciana da Silva Manoel Iluminação: Thiago Henrique Martinez Maquiagem: Juliana de Paula Operador de luz: Thiago Henrique Martinez Contra-Regra: Leilaine Campioto Messias

Benevides

Bruno Kogi Yoshida: gigante e cavalheiro

\section{ELENCO}

Luciana Manoel: bruxa Torranha Mariane Rodrigues: madrasta e bicho

Edilaine Jesus: fada e dama Michele dos Santos: florzinha Elissa de Almeida: cavalheiro e carcará Philipe Lagrimante: cavalheiro e bicho Esther Marcondes: Luiza Soraya Pieretti: dama e bicho Felipe da Silva: gato Pepe Juliana Benevides: dama, árvore e professora. 


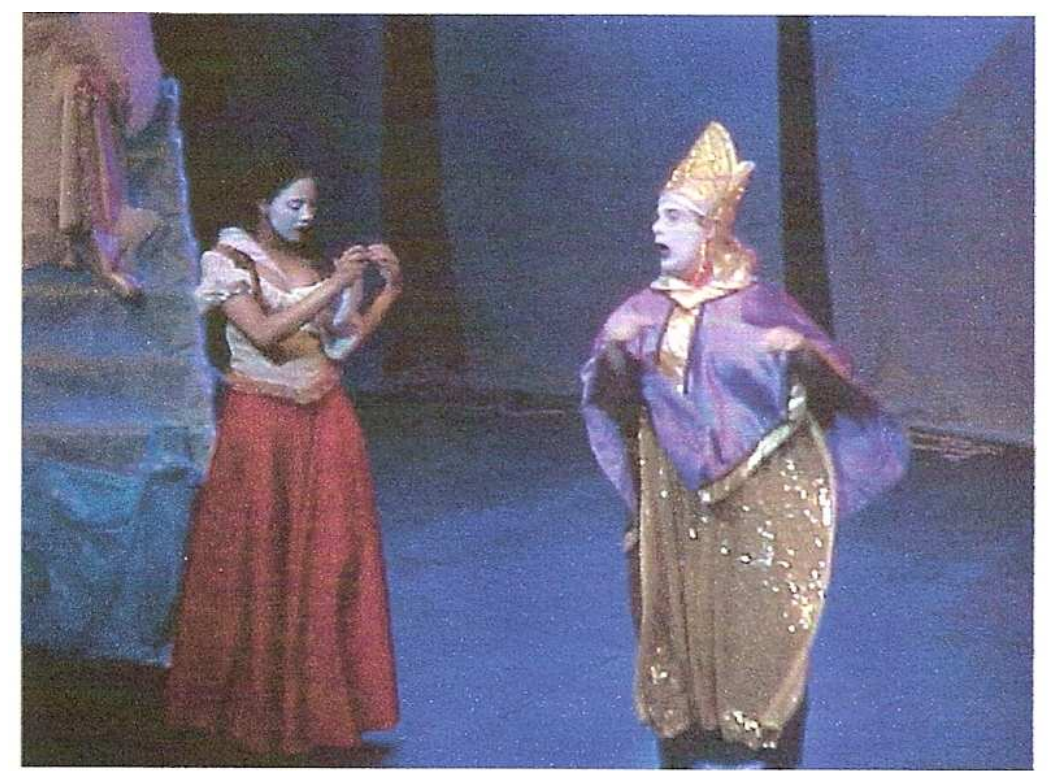

Autor: Gil Vicente (adaptado por Antônio de Oliveira e Daniela Cristine) Grupo: Elementos Anônimos

Escola: EE Ivens Vieira Cidade: Angatuba

O grupo que representava a escola Ives Vieira de Angatuba, dirigido por Antônio de Oliveira, vinha com grande número de acertos do espetáculo, mas, precisamente durante o debate percebemos que o grupo já não era formado mais por alunos e que tinham toda a estrutura de profissional. Tratava-se de um grupo que comercializava o espetáculo, mas que não tira o mérito do feito de um espetáculo estudantil. 


\section{RELEASE}

Visto como uma abordagem atual do conceito de inferno, o heavy metal e seus ícones (desde Kiss a King Diamond) foram acrescidos de sotaque lusitano para explicar o local de origem do texto (Portugal). A adaptação do vocabulário tornou-o fluente para os jovens atores e compreensível até para a platéia mais leiga.

Em tempo, a proposta de Gil Vicente, era exatamente esta: fazer teatro para a grande massa carente de arte mais que, ao mesmo tempo, julga culto como significado de chato.

O grupo quebra essa analogia fazendo um Gil Vicente que, mesmo respeitando a idéia original do dramaturgo, é dinâmico, atual e, sobretudo, divertido.

\section{FICHA TÉCNICA E ARTÍSTICA}

Diretor do espetáculo: Antônio de Oliveira

Figurino: Antônio de Oliveira Cenografia: O Grupo Sonoplastia: Antônio de Oliveira, Daniela Christine e Manoel F. Tenório Jr. Iluminação: O Grupo

Antônio de Oliveira: Diabo Alisson Hergesse: Diabinho Maíra Modolo: Diabete Adriana R. M. Machado: Anjo Douglas Fernando Lima: Fidalgo Fábio Augusto Santos: ajudante e parvo

Lacyr Cafundó: agiota

Sária Cristina Nogueira: costureira
Maquiagem: Manoel Ferreira Tenório Jr. Produção: Antônio de Oliveira e Daniela Christine Operador de som: Rudynei Augusto Hergessel e Daniel F. de Oliveira Operador de luz: Thiago Rolim Contra-Regra:

\section{ELENCO}

João Batista de Jesus: frade Gláucia Fernanda Rosa: amante Daniela Christine: Brísida Vaz Jefferson Christian: juiz Fábio Lopes Pereira: enforcado Bruno R. Américo Santi: cavaleiro Danilo Martins Rodrigues: cavaleiro Luiz Danilo Moreira Urso: cavaleiro Marcelo Donizete Soares: cavaleiro 


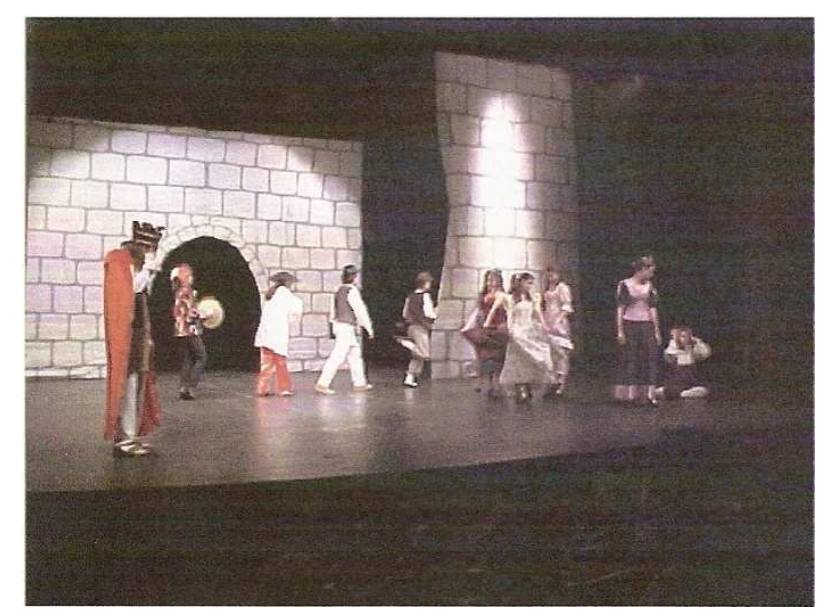

Autor: Vladimir Capella

Grupo: de Teatro Contra Tempo

Escola: Colégio Piracicabano

Cidade: Piracicaba

O espetáculo Clarão nas Estrelas que tinha como diretor Márcio Abegão, que também era professor do Colégio Piracicabano, desenvolvia um trabalho duas vezes por semana fora do horário de aula, como atividade extracurricular. Embora fosse um grupo formado apenas por estudantes no elenco, o processo que era desenvolvido ficava puramente claro que o mais importante era o resultado final e apresentação no festival. Dentro do colégio havia uma mostra de final de ano, em que o professor e diretor de teatro Márcio Abegão apresentava várias montagens divididas por turmas e fazia uma grande montagem o optou em inscrevê-la no festival.

Durante o debate muitos questionamentos foram levantados. Foi feita uma reflexão sobre o porquê de selecionar a partir de testes para a montagem principal e alguns alunos, durante o debate se mostravam frustrados, pois gostariam de continuar fazendo teatro com os companheiros. Não ficou bem claro, quando questionado, se esses alunos selecionados tinham uma espécie de nota pela participação. 
O espetáculo diz tanto do amor que aprisiona quanto do amor que liberta. E das muitas artimanhas e armadilhas que envolvem quem resolve empreender essa busca: a dor e a alegria, o medo e a coragem, a dúvida e a fé. "Clarão nas Estrelas" trata também desse grande mistério que é a vida. Mistério que a gente fica o tempo todo tentando desvendar para ter nas mãos o controle e o comando de algo que pede apenas para ser vivido com o coração transparente de uma criança. É um texto que, em outras palavras, acredita no encontro.

\section{FICHA TÉCNICA E ARTÍSTICA}

Diretor do espetáculo: Márcio Abegão

Figurino: O Grupo Cenografia: O Grupo Sonoplastia: O Grupo

Gabriela Trigueiro: Camponesa 3 Hanna Schützer: Camponesa 1 Jéssica Salmazzi: Rainha Julia Cavalcanti: Maria Karina Degaspari: Intérprete/Camponês III/Anjo/Pescador Lis Blanco: Filha 5 Luciana Rugoni: Italiano/Mãe/Mensageiro Luiza Vaz: Operadora de Luz Maíra Moura: Filha 3
Iluminação: Adriano Pereira Maquiagem: Fabiane Martinez Produção: Márcio Abegão Operador de som: Simone Busato Operador de luz: Luiza Vaz Contra-Regra: Carlos Charles

\section{ELENCO}

Malú Palmieri: Pescador Mariana Fessel: Francês/Camponês II/Pai

Nara Marino: Chinês/Camponesa 2 Nathália Ansante: Filha 4 Nayara Muniz: Filha 2 Rafael Souza: Príncipe Raphael Torrezan: Alemão/Camponêsl/Anjo Rubens Vitti Jr.: Rei Thais Projete: Filha 1 Verônica Roncato: Oriental/Anjo 


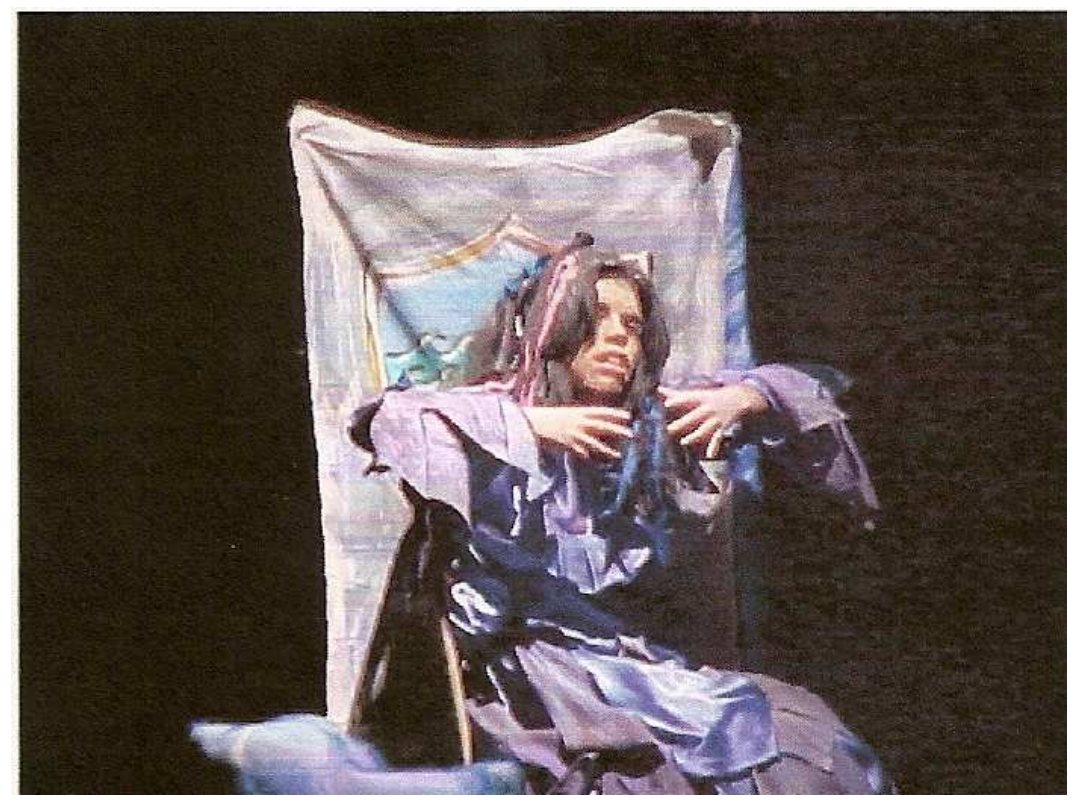

Autor: Nelson Rodrigues (adaptação João Carlos Luz)

Grupo: Grupo de Teatro "Em Cena Ação"

Escola: EE Modesto Tavares de Lima

Cidade: Itapetininga

João Carlos Luz, diretor do Espetáculo traz mais uma vez uma adaptação, feita por ele, de Nélson Rodrigues, embora tenha surpreendido no primeiro festival o espetáculo tinha algumas deficiências. Durante o debate percebeu-se que o grupo não queria mais seguir a mesma linha que vinha sendo proposta pelo diretor. O grupo se desfez porque a maioria dos integrantes estava no $3^{\circ}$ ano do ensino médio. O diretor segue carreira profissional solo na cidade de são Paulo, mas a efervescência cultural de cidade ainda continua acesa e uma reflexão deve ser leva em conta. Os alunos que se formam devem ter espaço na escola para dar continuidade ao trabalho. 


\section{RELEASE}

O texto conta a saga de uma família tradicional "os Drummond" que é perseguida por uma seqüência de mortes misteriosas. Com o desenrolar das cenas nota-se que há uma ligação entre as mortes: todas acontecem perto do mar, fato que será fundamental para o desfecho do espetáculo. Esta obra ímpar do dramaturgo Nélson Rodrigues mostra com uma linguagem extremamente poética das deterioradas relações familiares, em que a protagonista "Moema" deseja e trabalha para ser o único foco de atenção de seu pai, o juiz Dr. Misael Drummond não medindo esforços para tirar do seu caminho quem quer que seja incluindo a sua própria mãe.

Personagens densos e mergulhados em abismos interiores com diálogos e monólogos fortes, nos quais os complexos de Édipo, Electra e Fedra são a temática central do texto fazem de Senhora dos afogados um espetáculo reflexivo em que as mais profundas mazelas dos seres humanos são discutidas.

\section{FICHA TÉCNICA E ARTÍSTICA}

Diretor do espetáculo: João Carlos Luz Figurino: Renata Carriel

Cenografia: Werner Krapf, Fernando Magalhães e Kellen Oliveira

Sonoplastia: Breno Ruiz, Bob Vieira, Leila Santos e Graziele Carvalho lluminação: Moacyr Prado e João Carlos Luz

Paulo S. Carriel: Dr. Misael

Fernanda Ap. Soares: Dona Eduarda Thaís Fernanda Souto de A Oliveira: Moema Fernando da Silva Magalhães: Paulo, vizinho e cantor

Priscila Albuquerque Ferreira: Dona Marianinha e vizinha

Fernando dos Reis Medeiros: noivo e vizinho Fagner Muniz dos Santos: vizinho Renata Alves Carriel: vizinha Graziele Carvalho da Silva: mulher do cais e cantora
Maquiagem: Paulo Carriel

Produção: Grupo de Teatro Em Cena Ação

Operador de som: Mário Fernando Barbosa de

Andrade

Operador de luz: Moacyr do Amaral Prado Neto

Contra-Regra: Grupo de Teatro Em Cena Ação

ELENCO

Paulline Ferrari: vizinha, mulher do cais, cantora e espelho

Kellen C. de Carvalho Oliveira: vizinha, mulher do cais e espelho

Luiz Antônio Vieira: sabiá e músico

Breno Ruiz Perez de A Simatti: vendedor de pentes e músico

Leila da Silva dos Santos: avó do noivo e cantora

Fabiana Alves do Nascimento: mulher dos cais 
O PALHAÇO ERA MEU TIO

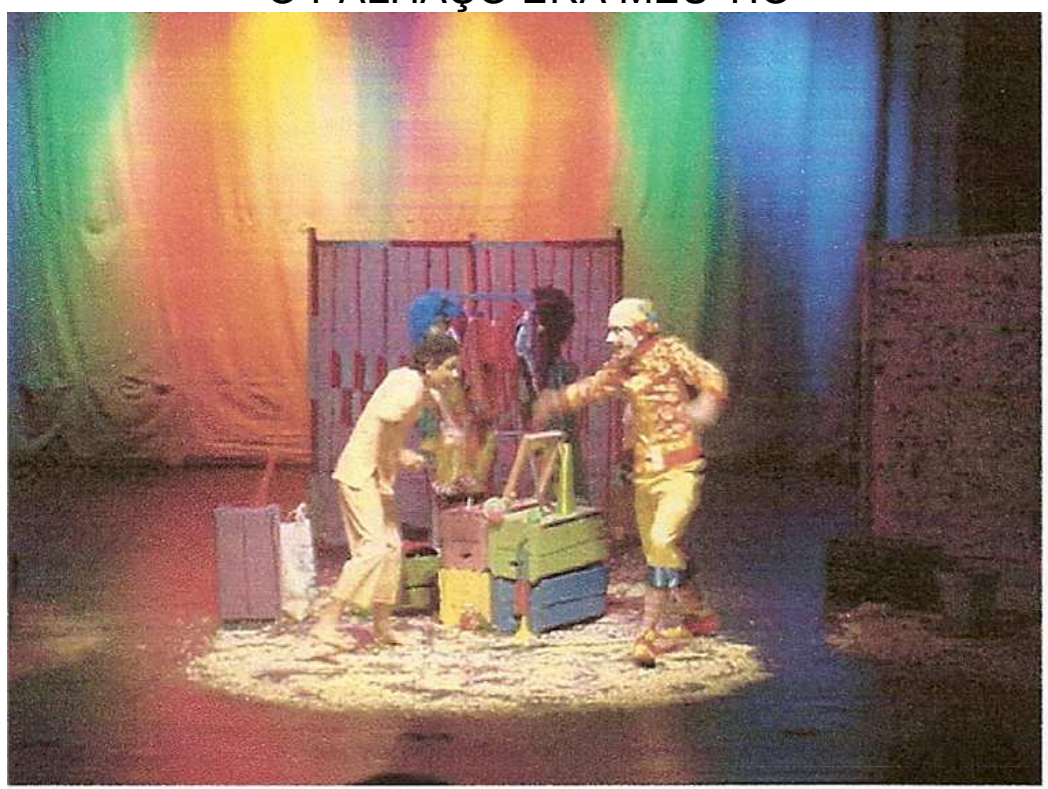

Autor: Ronaldo Ciambroni

Grupo: Cia Pereirão de Teatro

Escola: EE Chico Pereira

Cidade: Tatuí

A Cia Pereirão de Teatro se apresenta novamente no $2^{\circ}$ Festival sob a direção do professo André Luiz Camargo. O espetáculo que ganha mais qualidade e mostra uma preocupação no processo de pesquisa vem com grande nível de acerto de cenografia, sonoplastia e com uma iluminação impecável. $\mathrm{O}$ grupo mostra-se mais maduro e os participantes, durante 0 debate, nitidamente, buscam pesquisas. 


\section{RELEASE}

Peça de Ronaldo Ciambroni e adaptada por André Luiz Camargo, $O$ Palhaço era meu tio, fala do mundo do circo, mais propriamente dito da vida do palhaço do circo. Zé é o primo do palhaço Minhoquinha e, antes de cada sessão, lá estava o Zé no camarim, vendo o seu tio se preparar para o picadeiro. Nesse maravilhoso mundo do circo, Zé conhece a alegria do sucesso e o gosto amargo do fracasso em um mundo particularmente mágico.

O espetáculo ambientado principalmente nos bastidores do circo fala da dificuldade da vida do artista, do amor entre família, da amizade, de alegrias e tristezas. E tudo isso regado ao clima extremamente alegre. O clima do palhaço do circo. Esquetes circenses de palhaços distribuídos durante 0 espetáculo dão um charme todo especial a peça.

\section{FICHA TÉCNICA E ARTÍSTICA}

Diretor do espetáculo: André Luiz Camargo

Figurino: Sérgio da Silva Franco Cenografia: João Armando Fabro e Tiago Castro Leite Sonoplastia: André Luiz Camargo Iluminação: André Luiz Camargo Maquiagem: Jaqueline Gabriel Cardoso e Maria Teixeira de Almeida

João Armando Fabro: tio Germano Luciane de Oliveira: tia Jandira Fernando Henrique Casalunga: Zé criança

Tiago Castro Leite: Zé adulto
Produção: Cia Pereirão de Teatro Operador de som: João Balieiro e Ranieri Guerra Operador de luz: Júlio Pezzoni Arruda e Michel Navarro Miranda Contra-Regra: Sara Rivera, Ana Cristina Silva Costa, Mari Pinheiro, Marcelo Gasparini e Wesley Franco

\section{ELENCO}

Maria Teixeira de Almeida: Pirilim 1 Jaqueline Gabriel Cardoso: Pirilim 2 Elton Pinheiro: Dono do Circo Iria de Moura Sotero: Mágico 


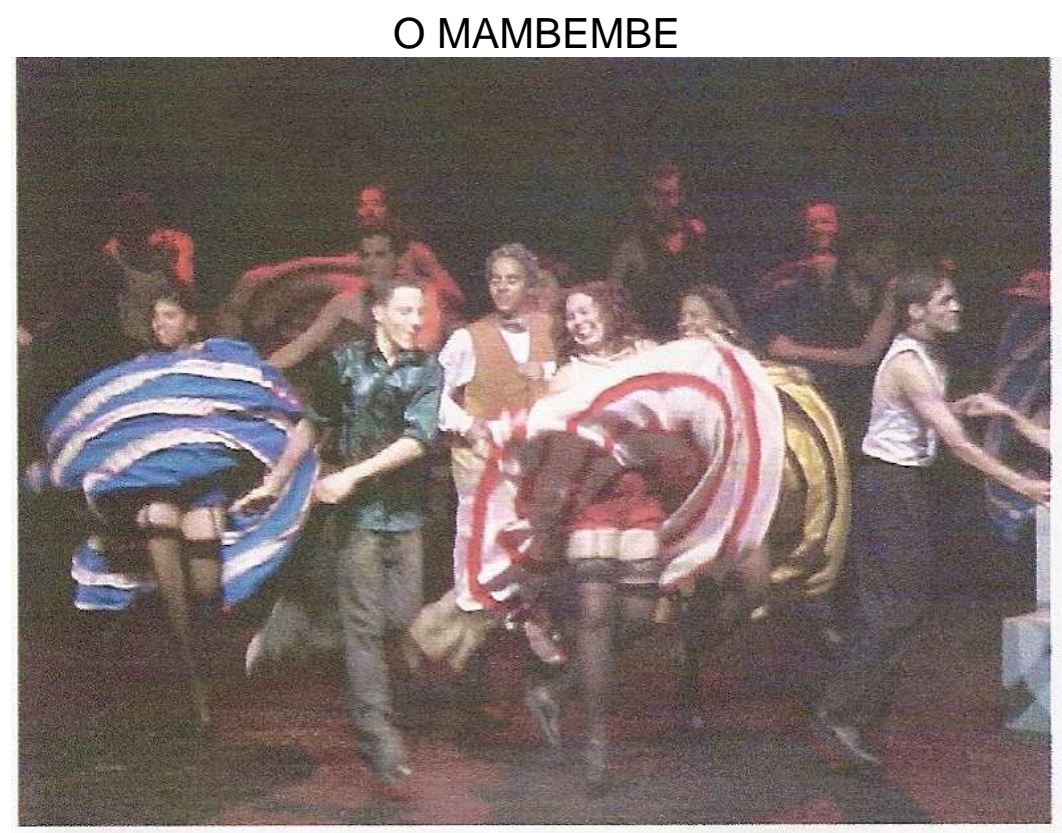

Autor: Artur Azevedo

Grupo: Tal \& Pá

Escola: EE Prof ${ }^{\mathrm{a}}$ Maria Augusta de Ávila

Cidade: São Paulo

Grupo Tal\&Pá, da Escola Estadual Professora Maria Augusta de Ávila, que tem como diretora Valéria de Oliveira e Simone Bragiatto, mostrou com evidência a alegria dos alunos em participar do grupo. Valéria, diretora-mãe e que procurava com poucos recursos proporcionar um processo de pesquisa e elaboração do projeto com uma qualidade ímpar. Fundamentalmente, o grupo que vem da periferia de São Paulo traz um belíssimo espetáculo com grandes momentos criativos da direção. Com cubos e guarda-chuvas e um belo figurino, o espetáculo de compôs de maneira generosa e assertiva. 


\section{RELEASE}

O Mambembe é uma peça de teatro sobre o teatro, numa verdadeira metalinguagem. A organização da companhia, os tipos que a compõem, os problemas financeiros, as dificuldades com as autoridades locais, com os conquistadores de província, com os coronéis, com o repertório, com as condições técnicas dos locais de representação, tudo é examinado e, como resultado final, há uma exaltação do trabalho dos artistas cênicos e do próprio teatro.

\section{FICHA TÉCNICA E ARTÍSTICA}

Diretor do espetáculo: Valéria de Oliveira e Simone Bragiatto

Figurino: Grupo Tal \& Pá

Cenografia: Grupo Tal \& Pá

Sonoplastia: Soraya de Oliveira

Iluminação: Leandro Queiroz

Maquiagem: Grupo Tal \& Pá

Produção: Grupo Tal \& Pá

Operador de som: Soraya de Oliveira e Carina Viana

Operador de luz: Leandro Queiroz e Gabriela Almeida

Contra-Regra: Camilla Cristiane, Carina Viana, Paulo

Anderson Luís: Florêncio

César e Adriano Lisboa.

Carlos Silva: Humberto

Carol Silva: Margarida

Cássia Freitas: Leonora

Cristiana Fabrício: Laudelina

Débora Silva: dançarina de can can

Edgar Santa Bárbara: Antônio Pedro, o cangaceiro

ELENCO

Eduardo Carvalho: ator

Fabiola dos Santos: cenário/cangaceira

Francilene Silva: dançarina de can can

Gisele Xavier: dançarina de can can

Ivan Silvatti: Lopes

Jones Marinho: Coutinho e cenário

Juliana Lamotta: Luiza

Lúcia Leão Nunes: Mariana

Marcelo Henrique: Pantaleão

Paula Paranhos: dançarina de can can

Raul Retucci: Tobias e cenário

Reinaldo Soledade: Vieira

Renata Silva: dançarina de can can

Roberta Quirino: cenário e cangaceira

Robson Job: Monteiro e cenário

Robson Salvador: Eduardo

Suellen Santana: Aurora

Tatiana Fabrício: cenário e cangaceira

Tatiane Alves: cenário e cangaceira

Tony Leão Nunes: subdelegado e cenário

Walcir Alves: cenário e cangaceiro 


\section{A INCRÍVEL VIAGEM PELO CORPO HUMANO}

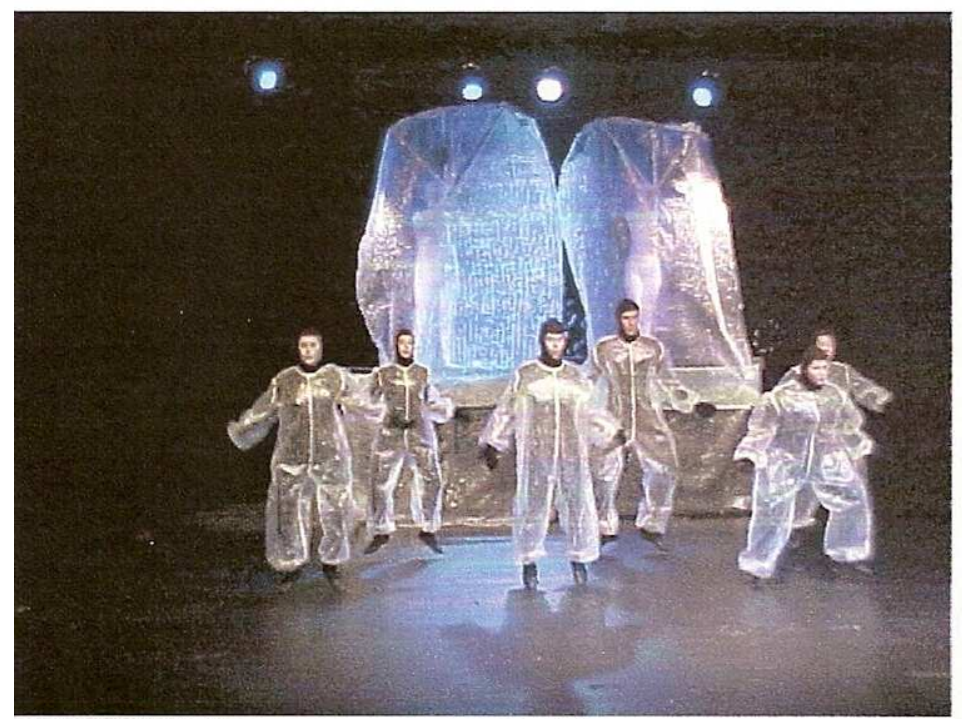

Autor: Ivan Lovison

Grupo: Teen de Teatro

Escola: Colégio Santo Agostinho

Cidade: São Paulo

De uma maneira divertida e deliciosa, a professora de Biologia e do espetáculo Pámela Paz mostra uma verdadeira aula pelo corpo humano no palco, ficava evidenciado o processo que desenvolvia com seus alunos, que ao fazer teatro também se apropriavam da Biologia. O público, formado quase que $90 \%$ por crianças, saiu encantado do teatro. Durante o debate, o elenco se colocou e não só explicou sobre o processo de montagem, mas também sobre os órgãos que interpretavam e sobra a pesquisa que ali realizavam. 


\section{RELEASE}

O prólogo começa numa típica sexta-feira, quando o sinal da escola toca e a algazarra das crianças, saindo da aula, toma conta do ambiente. Elas estão se preparando para a grande feira de ciências da escola e um grupo formado por Dudu, Gigi e Paty, pretende pesquisar uma curiosa lenda do bairro: a presença de um gigante chamado Fanhoso nas redondezas. Ao se encontrarem com o gigante, os três começam a provocá-lo e este furiosíssimo, o os engole. $\mathrm{Na}$ boca do gigante, as crianças começam uma longa jornada e passam por diversos órgãos, como: esôfago, estômago, vasos sangüíneos, pulmões, coração e cérebro... Desesperados, mas também fascinados, elas procuram por uma saída antes que sejam digeridas e acabam se transformando em... cocô! Durante toda a viagem conhecem vários personagens estranhos e engraçados como, por exemplo, uma excêntrica cenoura que tem passado os últimos momentos de sua vida fugindo do suco gástrico.

Com a ajuda de todos eles encontram a saída adequada e já tem uma fascinante história para contar na feira de ciência.

\section{FICHA TÉCNICA E ARTÍSTICA}

Diretor do espetáculo: Pámela Paz e Fábio Maquiagem: Grupo Teen de Teatro

Hilst

Figurino: Aríete Castro

Cenografia: Gilson Faria

Sonoplastia: Gilson Faria

lluminação: Gabriel Kofka e Fábio Hilst

Breno Fonseca: corpo de baile

Bruna Lara: corpo de baile

Camila Yumi: gigi

Cris Lima: célula e coração

Daniella Faria: cárie e corpo de baile

Danilo Eugênio: rim e neurônio

Felipe Alpert: dudu

Produção: Grupo Teen de Teatro

Operador de som: Fábio Hilst

Operador de luz: Gabriel Kofka

Contra-Regra: Victor Mugnaíni

Flora Braz: úlcera e corpo de baile

Henrique Faria: banana e rim

\section{ELENCO}

Inara Santos: cenoura

Mariana Vitali Costa: corpo de baile

Pablina Araújo: paty

Patrícia de Castilho: pulmão

Rafael Junqueira: língua e oxigênio

Bebeca Damião: beterraba e dente

Tiago Lorenos: frango e pulmão

Yuri Saito: chuchu e gás carbônico

\section{PEDRO E INÊS - UMA VERDADEIRA HISTÓRIA DE AMOR}




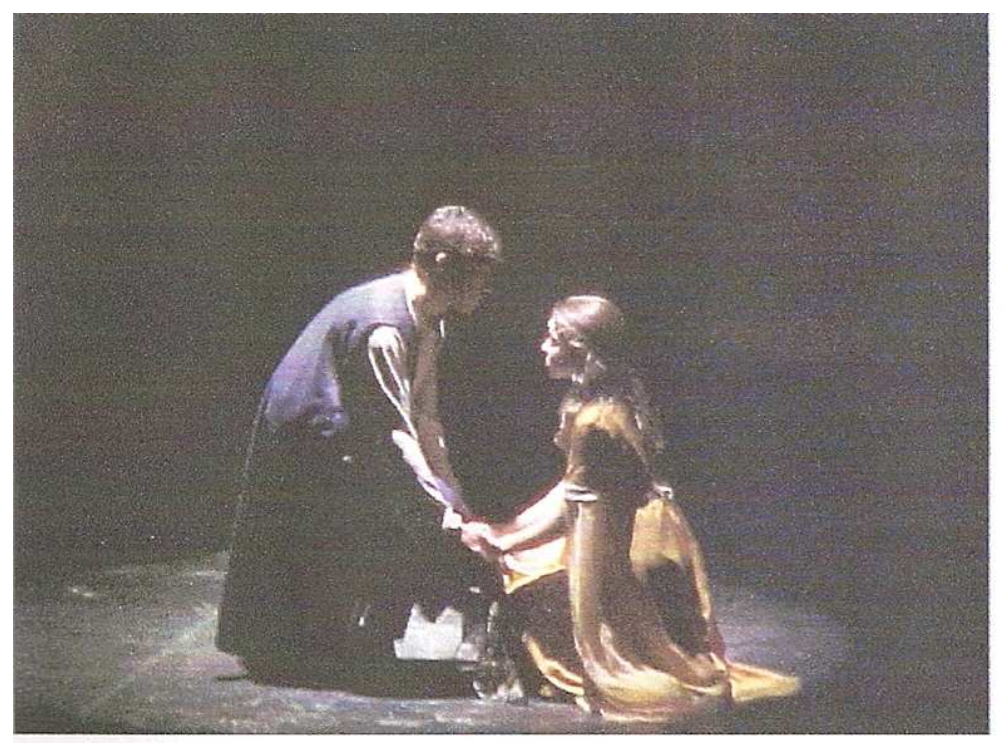

Autor: Tânia Cristiana dos Santos Boy

Grupo: Gualberto Moreira

Escola: EE Dr. Gualberto Moreira

Cidade: Sorocaba

Este espetáculo de autoria de Tânia Cristina dos Santos Boy que também assina a direção é professora de língua portuguesa na escola e desenvolveu o trabalho através de suas aulas de literatura. O espetáculo de um bairro da periferia de Sorocaba, embora bem realizado não chegava a se compor como um grupo a pesquisa. E era muito bem fundamentada sobre 0 assunto, mas não havia uma pesquisa de trabalho claramente estabelecida com o grupo. Concluiu-se que a pesquisa era da professora/diretora e necessitava de mais tempo para que os alunos pudessem transitar melhor pela história. Era claro e evidente que ali se iniciava um grupo com um respaldo. 
RELEASE

A peça conta a história de Inês de Castro, uma mulher que foi rainha depois de morta, sendo este fato único na história.

Os acontecimentos se passam em Portugal, no início dos anos 1300 e mostra a luta pelo poder e as intrigas políticas para manter o trono daquele país. Essa história real é marcada por paixões proibidas, intrigas, arranjos políticos, traições, vingança e crueldades cometidas em nome do amor e do bem do povo.

\section{FICHA TÉCNICA E ARTÍSTICA}

Diretor do espetáculo: Tânia Cristina Produção: Tânia Cristina dos dos Santos Boy

Figurino: Lucineide Francisca

Zanivan

Cenografia: Mateus da Silva

Sonoplastia: Cássia Regiane Silva

Iluminação: Everton M Souza

Maquiagem: Marli Giselda Vidal

Vera

Santos Boy

Operador de som: Cássia Regiana

Silva

Operador de luz: Everton M. Souza

Contra-Regra: Marisa Campos

Oliveira
Adriana Cruz: dama

Amanda do Carmo: Inês

Ana Laura Furigo: garota

Ana Maria Vieira: Teresa

Bianca Rodrigues: Dona Branca

Camila Rocha: Rainha Beatriz

Carine Ramos: Constança

Diego Kenit: Afonso Madeira

Elton Oliveira: Álvaro
ELENCO

Graciele Cubillas: Leonor

Kelly Cristina: Catarina

Renan Simões: Pero Coelho

Rodrigo Almeida: Rei Afonso

Thiago Moura: Pedro

Pedro Henrique: D Dinis

Mateus Silva: Diogo Pacheco

Natália Gálio: madre 


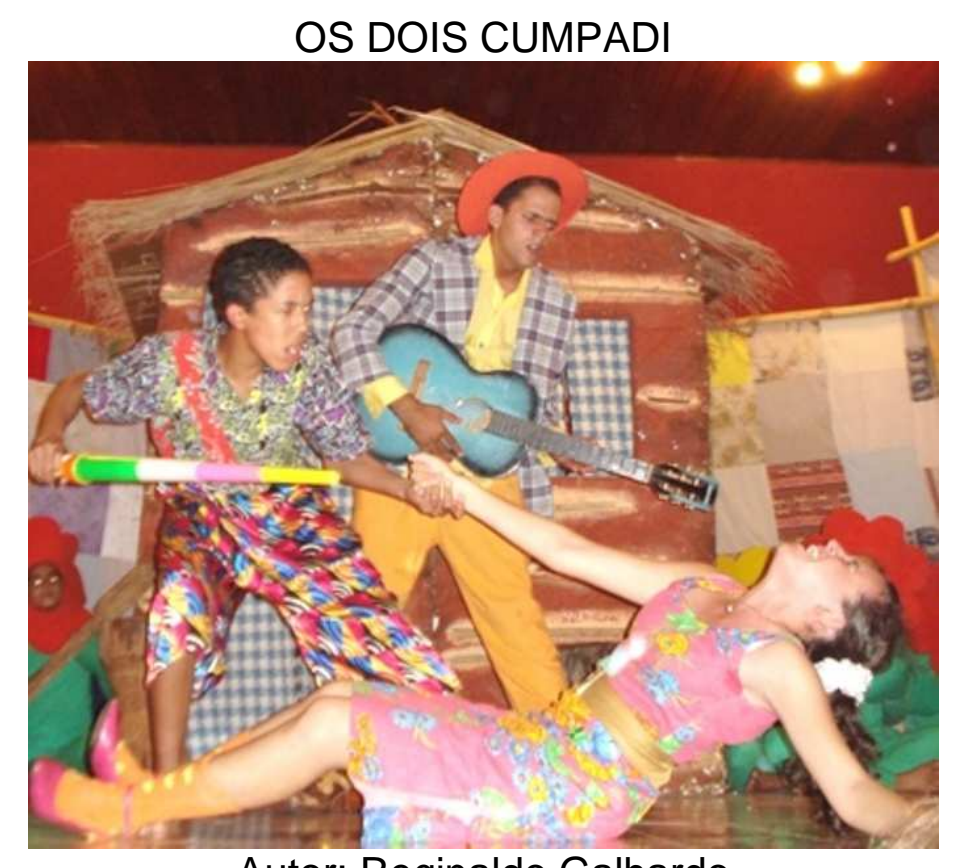

Autor: Reginaldo Galhardo Grupo: Teatral

Escola: Maria Ângela B. Dias

Cidade: Paraguaçu Paulista

Do autor e diretor Reginaldo Galhardo, participa deste $2^{\circ}$ Festival novamente com uma superprodução desenvolvida na cidade de Paraguaçu Paulista. Reginaldo, que já teve textos publicados na Revista Teatro da Juventude. Os textos são, indubitavelmente, de grande qualidade, assim como seus espetáculos. Vimos durante a reflexão e sem procurar delatar, que o mesmo já comercializava os espetáculos com as crianças e foi colocado em questão seu processo de trabalho. Constatou-se que seu grupo, infelizmente, não tinha mais o perfil estudantil e isso foi percebido in loco quando encontramos o grupo se apresentando na capital paulista com cobrança de ingressos. A partir disto, o grupo nunca mais se inscreveu para participar do festival. 


\section{RELEASE}

O Grupo Teatral da Escola Maria Ângela apresenta o espetáculo infantojuvenil Os dois cumpadi que conta as peripécias do Cumpadi Pobre e sua família esfomeada e esfarrapa quando já cansados de passar por tantos apuros, dificuldades e humilhações por parte do Cumpadi Rico, fazendeiro ganancioso e aproveitador, resolvem aplicar-lhe alguns golpes mirabolantes, na tentativa de conseguir por mal aquilo que não conseguem por bem. É aí que as coisas se desarrumam ainda mais...

Nunca foi tão divertido se divertir.

\section{FICHA TÉCNICA E ARTÍSTICA}

Diretor do espetáculo: Reginaldo Galhardo Figurino: Jonathas Levinski

Cenografia: Tiago César de Abreu Sonoplastia: Evandro G. Pedroso lluminação: Mario Lúcio Florêncio Maquiagem: Nilza Guerino de Lima

Produção: Grupo de Teatro Escola Maria Angela Operador de som: Evandro G. Pedroso Operador de luz: Mario Luíco Florêncio Contra-Regra: Marcelo Gregorio e Alessandro Gomes Goulart

\section{ELENCO}

Samira S. Moura: Contadora Pamela F. Zanluchi: Menina 1 Camila A. de Mello: Menina 2 Michele Canevari: Menina 3 Bruna Ap. Silva: Menina 4 Viviane A. Pires: Menina 5 Isabelli Maia: Menina 6 Arlindo Canato Filho: Cumpadi pobre

Nayara Santos Aniceto:

Cumadi pobre

Érique S. Bezerra: Filho pobre Pablo A. R. Matta: Cumpadi rico

Luiz H. B. Francisco: Capanga 1
Claudinei da Silva Menezes: Capanga 2 Adriano Ramos Stern: Capanga 3 Alessandro Antônio Gomes Goulart: Capanga 4

Ediney Bueno: Boiadeiro

Renata Maria Pilan: Cumadi rica

Renata Maria Pilan: Sereia

Cláudio Corrêa: Quarilha

João R. B. Francisco: Quarilha

Marluci E. de Oliveira: Quarilha

Daniela Campos: Quarilha

Vanessa M. S. Braz: Quarilha

Daniela Baptista Marques: Quarilha

Julia B. Oliveira: Coro de flores

Thalita Cristina da Costa: Coro de flores

Tamiris C. de Oliveira: Coro de flores

Rosiane Ap. Durigan: Coro de flores
Cíntia V. Gomes: Coro de flores

Priscila Caldeirão: Coro de

flores

Tuany R. da Silva: Coro de

flores

Jéssica N. Paiâo: Coro de

flores

Amanda S. Pessoa: Coro de

flores

Daiane de M. Pedro: Coro de

flores

Natália F. C. Rocha: Coro de

flores

Francielen T. N. da Motta:

Coro de flores 


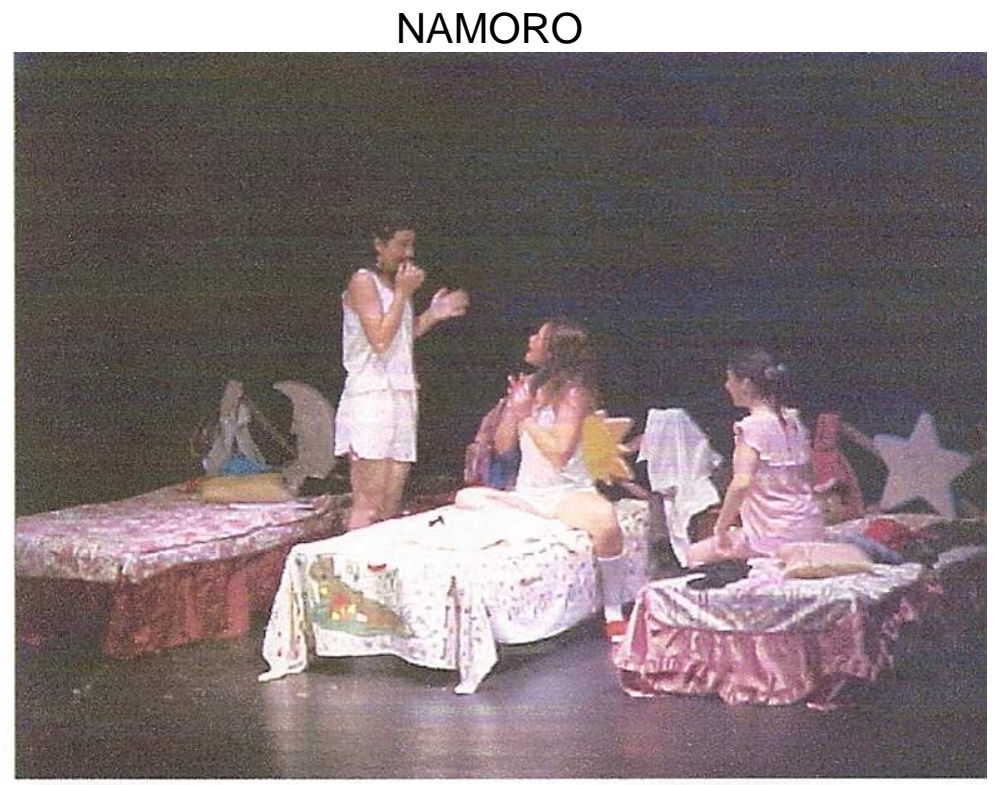

Autor: líder Miranda Costa

Grupo: Famíla Matula de Teatro

Escola: EE Prof. Lauro Sanchez

Cidade: Sorocaba

O grupo Família Matula de Teatro que participou do $1^{\circ}$ Festival com dois espetáculos, retorna neste segundo com um resultado da inquietação do ator Francisco Antonio Neto, que pela participação no primeiro, assume a frente do grupo como diretor, tendo como orientador o professor Rubens Espírito Santo, o que coloca este grupo mais claramente nos objetivos do festival. 


\section{RELEASE}

Namoro, de líder Miranda Costa, conta a história de três irmãs que estão vivendo a fase da adolescência onde um universo de dúvidas e conflitos internos e externos começa a despontar.

FICHA TÉCNICA E ARTÍSTICA

Diretor do espetáculo: Francisco Antônio Neto (Chico Neto)

Figurino: o Grupo

Cenografia: o Grupo

Sonoplastia: Alessandra Prandi e Chico Neto

Iluminação: Chico Neto e Rubens Espírito Santo

Maquiagem: o Grupo

Produção: o Grupo

Operador de som: Robson Guimarães de Faria

Operador de luz: Rubens Espírito Santo

Contra-Regra: Marilene Fernandes

Alessandra Prandi: Esteia

ELENCO

Ana Paula Antunes: Simone

Gislene Freitas: Margarida

Chico Neto: funcionária asquerosa 
PREMIAÇÃO CATEGORIA INFANTIL

\begin{tabular}{|c|c|c|c|c|c|}
\hline & $\begin{array}{l}\text { CLARÃO NAS } \\
\text { ESTRELAS }\end{array}$ & $\begin{array}{l}\text { BAILE DOS } \\
\text { SONHOS }\end{array}$ & $\begin{array}{l}\text { P PALHAÇO } \\
\text { ERA MEU TIO }\end{array}$ & $\begin{array}{c}\text { A INCRIVEL } \\
\text { VIAGEM PELO } \\
\text { CORPO } \\
\text { HUMANO } \\
\end{array}$ & OS DOIS CUMPADI \\
\hline $\begin{array}{l}\text { ATOR } \\
\text { REVELAÇÃo }\end{array}$ & & & & & ATOR REVELAÇÃO \\
\hline $\begin{array}{l}\text { ATRIZ } \\
\text { REVELAÇÃo }\end{array}$ & & & & CRIS LIMA & \\
\hline $\begin{array}{l}\text { COADJUVANTE } \\
\text { MASCULINO }\end{array}$ & & & & $\begin{array}{l}\text { HENRIQUE } \\
\text { FARIA }\end{array}$ & \\
\hline $\begin{array}{l}\text { COADJUVANTE } \\
\text { FEMININO }\end{array}$ & $\begin{array}{l}\text { COADJUVANTE } \\
\text { FEMININO }\end{array}$ & & & & \\
\hline CENOGRAFIA & & & & GILSON FARIA & \\
\hline ILUMINAÇÃO & $\begin{array}{l}\text { ANDRE LUIZ } \\
\text { CAMARGO }\end{array}$ & & & & \\
\hline FIGURINO & $\begin{array}{l}\text { SÉRGIO DA } \\
\text { SILVA FRANCO }\end{array}$ & & & & \\
\hline MAQUIAGEM & & $\begin{array}{l}\text { JULIANA DE } \\
\text { PAULA } \\
\text { BENEVIDES }\end{array}$ & & & \\
\hline SONOPLASTIA & & & & & $\begin{array}{l}\text { EVANDRO G. } \\
\text { PEDROSO }\end{array}$ \\
\hline DIREÇÃO & & & & & $\begin{array}{l}\text { REGINALDO } \\
\text { GALHARDO }\end{array}$ \\
\hline MELHOR ATOR & & & & & MELHOR ATOR \\
\hline MELHOR ATRIZ & MELHOR ATRIZ & & & & \\
\hline $\begin{array}{l}\text { MELHOR } \\
\text { ESPETÁCULO JURI } \\
\text { POPULAR }\end{array}$ & & $\begin{array}{l}\text { BAILE DOS } \\
\text { SONHOS }\end{array}$ & & & \\
\hline $\begin{array}{l}\text { MELHOR } \\
\text { ESPETÁCULO }\end{array}$ & & & & $\begin{array}{l}\text { A INCRIVEL } \\
\text { VIAGEM PELO } \\
\text { CORPO } \\
\text { HUMANO }\end{array}$ & \\
\hline
\end{tabular}




\section{PREMIAÇÃO CATEGORIA ADULTO}

\begin{tabular}{|c|c|c|c|c|c|}
\hline & NAMORO & $\begin{array}{l}\text { PEDRO EINÊS- UMA } \\
\text { VERDADEIRA HISTORIA } \\
\text { DE AMOR }\end{array}$ & $\begin{array}{l}\text { SENHORA DOS } \\
\text { AFOGADOS }\end{array}$ & $\begin{array}{l}\text { AUTO DA } \\
\text { BARCA DO } \\
\text { INFERNO }\end{array}$ & O MAMBEMBE \\
\hline $\begin{array}{l}\text { COADJUVANTE } \\
\text { MASCULINO }\end{array}$ & & DIEGO KENIT & & & \\
\hline $\begin{array}{l}\text { COADJUVANTE } \\
\text { FEMININO }\end{array}$ & $\begin{array}{l}\text { ALESSANDRA } \\
\text { PRANDI }\end{array}$ & & & & \\
\hline CENOGRAFIA & & & $\begin{array}{l}\text { WERNER KRAPFF } \\
\text { FERANAND } \\
\text { MAGALAEESE } \\
\text { KELLEN OLIVEIRA }\end{array}$ & & \\
\hline ILUMINAÇÃO & & & $\begin{array}{c}\text { MOACYR PRADO } \\
\text { E JOÃO CARLOS } \\
\text { LUZ }\end{array}$ & & \\
\hline FIGURINO & & & $\begin{array}{l}\text { RENATA } \\
\text { CARRIEL }\end{array}$ & & \\
\hline MAQUIAGEM & & & PAULO CARRIEL & & \\
\hline SONOPLASTIA & & & & & $\begin{array}{l}\text { SORAYA DE } \\
\text { OLIVEIRA }\end{array}$ \\
\hline $\begin{array}{l}\text { MELHOR } \\
\text { COREOGRAFIA }\end{array}$ & & & & $\begin{array}{c}\text { MELHOR } \\
\text { CENOGRAFIA }\end{array}$ & \\
\hline DIREÇÃO & & & $\begin{array}{c}\text { JOÃO CARLOS } \\
\text { LUZ }\end{array}$ & & \\
\hline MELHOR ATOR & & & MELHOR ATOR & & \\
\hline MELHOR ATRIZ & & & MELHOR ATRIZ & & \\
\hline $\begin{array}{l}\text { MELHOR } \\
\text { ESPETACULO JURI } \\
\text { POPULAR }\end{array}$ & NAMORO & & & & \\
\hline $\begin{array}{l}\text { MELHOR } \\
\text { ESPETÁCULO }\end{array}$ & & & & & O MAMBEMBE \\
\hline
\end{tabular}




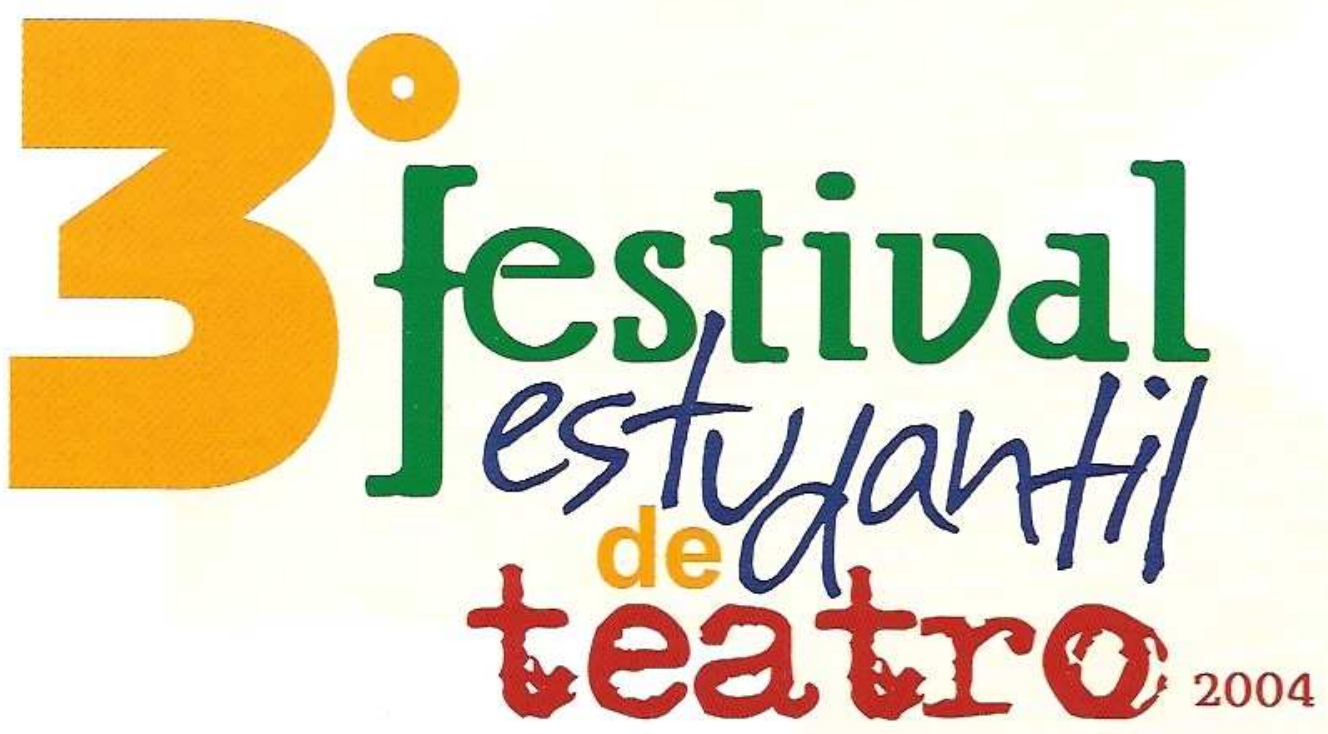

realizaçăa - apoio

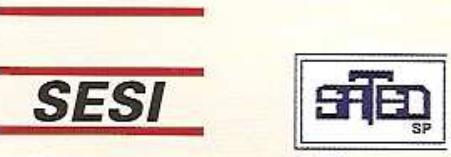




\section{3ํFestival Estudantil de Teatro 2004}

O $3^{\text {o }}$ Festival Estudantil acontece com mais credibilidade perante a comunidade escolar, grupos novos se inscrevem e grupos que já participaram desde a primeira edição continuam a fazer parte. Os espetáculos foram analisados por, Claudia Dalla Verde ${ }^{12}$, Karin Mellone ${ }^{13}$ e Prof. Clóvis Garcia ${ }^{14}$.

Uma peculiaridade que surgiu foi o espetáculo $A$ Jibóia Gigante que nos surpreende já na sua inscrição. $O$ espetáculo traz um figurino criado com desenhos feitos pelas crianças, em que elas sinalizam até a própria cor dos tecidos, muitas vezes com uma escrita que nos faz perceber claramente 0 universo infantil. Em um dos desenhos vem descrito da seguinte maneira: "Corova de Brinquedo. Maquiagem como da minha mãe esmalte, pluma, lacinho e sapato". Um espetáculo totalmente feito por crianças, estudantes orientadas e coordenadas pela professora artista Elaine Busato e que a comissão julgadora não se colocou muito a favor do espetáculo dentro do contexto estudantil.

Outra peculiaridade foi Vidas Severinas, da cidade de Primavera, um espetáculo que como já foi analisado, mas, que cabe agora ressaltar, vem de uma cidade satélite projetada para os operários que foram desenvolver trabalho na Hidrelétrica e que ainda mais uma vez a comissão julgadora coloca em cheque a atuação desse grupo.

Estamos num terceiro festival fomentando a cultura e o repensar teatro deve ser de forma sustentável ao teatro estudantil. A minha indagação supera o resultado final, pois além desses dois espetáculos, entre outros participantes, percebo a grandeza do processo de trabalho. O que, em determinados 107

\footnotetext{
${ }^{12}$ Idem, nota 4, pág. 40.

${ }^{13}$ Fornada em Artes cênicas pela ECA USP,foi coordenadora do grupo Foco, que fez a pesquisa original dos jogos teatrais de Viola Spolin e concluiu com a montagem de "Genoveva Visita a Escola ou A Galinha Assada", de Madalena Freire. Atualmente é docente do Curso de Especialização em Teatro pela USC de Bauru.

${ }^{14}$ Professor aposentado pela Escola de Comunicação e Artes de SP. Professor Emérito da Universidade de São Paulo (USP). Ex-critico Teatral para Teatro Adulto durante 45 anos e para Teatro Infantil durante 20 anos
} 
momentos, parece que entra em contradição é a cobrança de uma estética teatral do produto, sem deixar bem definido para que participar de um festival estudantil. Quando algumas técnicas foram cobradas e a essência foi deixada de lado, esses dois grupos não deram continuidade aos seus trabalhos após a sua passagem por este festival. 
HISTÓRIAS ESCONDIDAS ENTRE RIOS E MARES

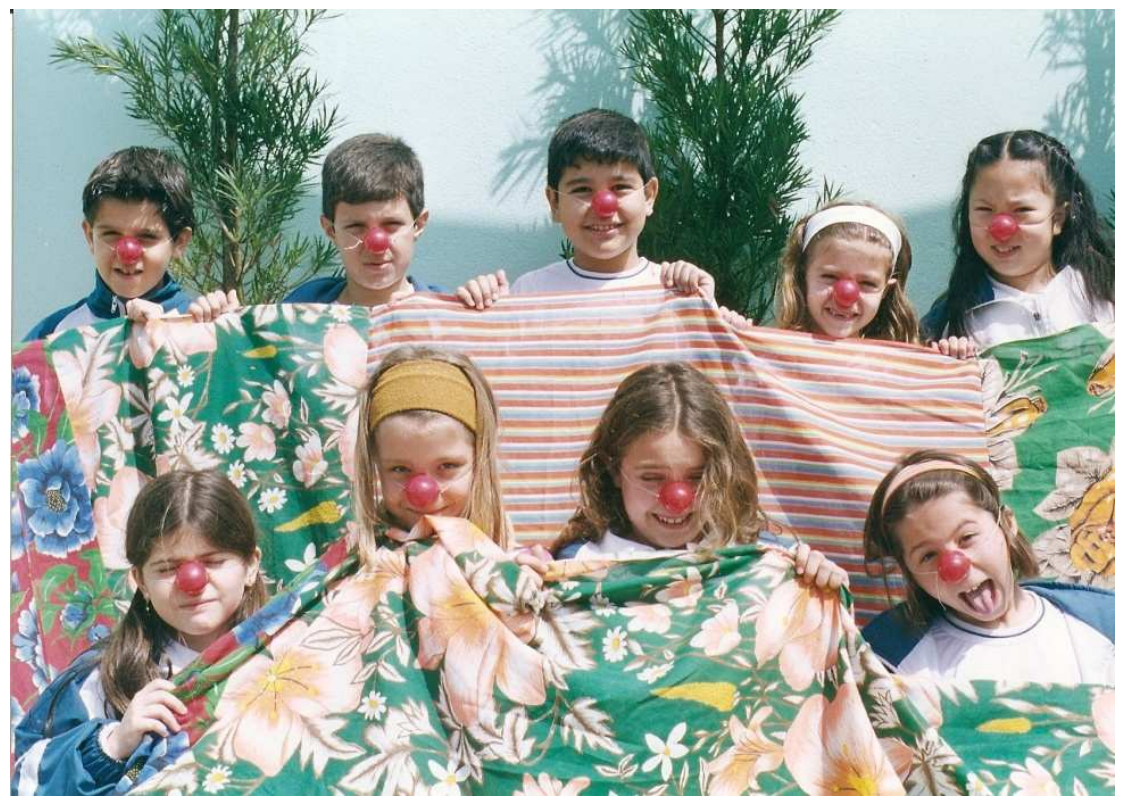

Autor: Eliane Buzato

Grupo:Cia Teatral A Jibóia Gigante

Escola: Colégio Bela Alvorada

Cidade: Sorocaba

A Cia Jibóia Gigante foi construída pela contadora de estória Eliane Buzato, com crianças entre 06 a 09 anos. O espetáculo era uma grande brincadeira que falava sobre lendas indígenas, em que as crianças podiam acrescentar o seu universo junto ao texto proposto pela autora, o cenário se compunha por figuras humanas. Um dos destaques foi um ator que tinha seis anos, que em um dado momento da peça, ele que entre seus personagens compunha um cogumelo, não ficou satisfeito o bastante com a inércia que talvez tenha tido que tomar e soltou o guarda-chuva que the servia como alicerce e foi logo colocando texto e surpreendendo toda a platéia. Este espetáculo foi um descortinamento para uma grande reflexão dos trabalhos que existem nas salas de aula e se tornam grandiosos pela sua essência. Durante o debate, a professora artista foi muito questionada com relação ao porquê mostrar um trabalho com crianças de tão pouca idade. 
Release

A peça apresenta duas jovens índias que escutam uma antiga lenda de sua tribo e decidem partir em viagem pelo mundo para desfazer um terrível feitiço que acomete seu povo. Nesta viagem, elas conhecem outras histórias: a do Canoeiro que se transformava em uma fruta juá toda noite de lua cheia e a da Princesa que tinha o rosto de prata.

Direção: Elaine Buzato Leme

FICHA TÉCNICA E ARTISTICA

Figurino: Elaine Buzato Leme

Cenografia: Elaine Buzato Leme

Maquiagem: Elaine Buzato Leme

Contra-Regras Fernanda Cristina de Souza, Edna Situa A. Moraes e Kelly

Cristina Q. da Situa

Produção Colégio Bela Alvorada

ELENCO

Elaine Buzato Leme (Contadora de Rebeca Felix Cardoso (Porta

Histórias)

Encantada)

Ualter Silua (Cantador)

Andréia Uieira Soares (Coro)

Cassiano Lai (Joaninha)

Cássia Pinto Basso (Rainha)

Lais Tozi Parri de Campos (irmã da

Cãinda)

Isabella Andriotta de França (Canoeira) Luana Camila Brisolla Ferreira (Cãinda)

Qiouanna Carrara (Bruxa)

Qustauo Cassar Uieira da Silua

Tayná Paula Leite (IHãe do Pescador)

(Pescador)

Júlia Ditta dos Santos (Porta

Encantada)

Gabriela Cau Uassali (Juá)

Líuia Ruiz (índia), Itlirna Lai (índia)

Bárbara Helena de Oliveira (Amor de Lonqe)

Laura Pontes Blézins de Araújo (irmã José Henrique Qallo Ferraz (Filho do

da Cãinda)

Cacique)

Leonardo Cassar Uieira da Silua (Baú) Letícia Sales Pereira (Coro) 


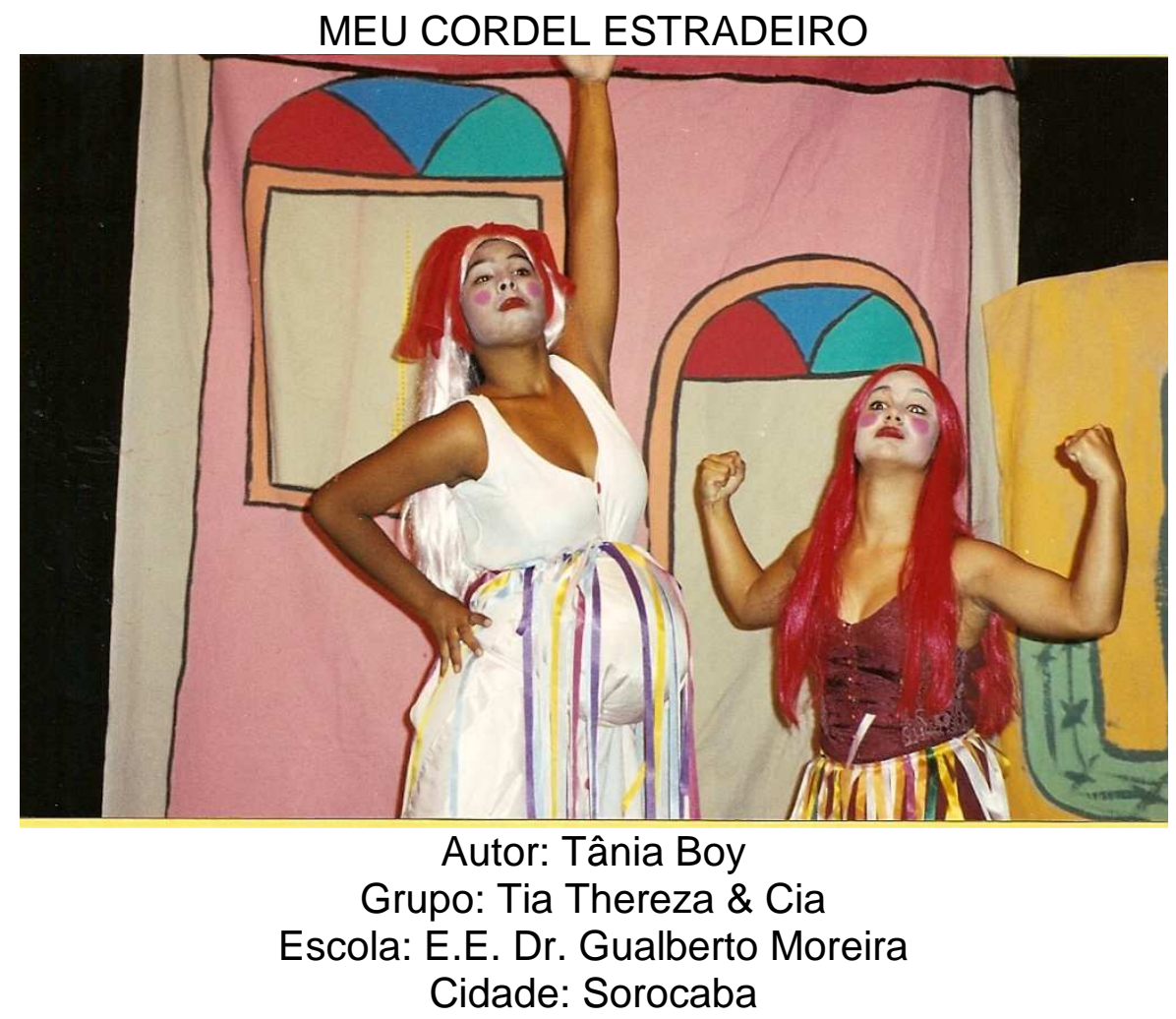

A Cia Thereza \& Cia aparece nesta $3^{\underline{a}}$ edição com um espetáculo mais próximo da realidade de seus integrantes, com um cenário produzido artesanalmente por eles mesmos. O grupo se fortalece na vivência dos festivais, que nessa fase estudantil, muitas das vezes, é a única oportunidade para se apresentarem em teatros com estruturas. A professora Tânia Boy com esforço e competência faz com que o grupo também tenha um bom desempenho, envolvendo os alunos e comunidades no processo criativo e no debate. 


\section{RELEASE}

É uma comédia que se passa numa feira no nordeste brasileiro e apresenta uma disputa entre dois cordelistas por um lugar para trabalhar. Tonho, que já trabalhava há tempos nesta feira, vê-se repentinamente frente a frente com Zé Quirino, outro cordelista que quer tomar seu lugar. Essa disputa se dá através de uma peleja musical e também pelas histórias dos livretos de cordel que eles apresentam. A peça faz uma homenagem à cultura nordestina, apresentando algumas de suas tradições, músicas, danças, lendas, mitos e literatura de cordel.

\section{FICHA TÉCNICA E ARTÍSTICA}

Direção: Tânia Boy

Figurino: Tânia Boy

Operadora de Luz: Tânia Boy

Iluminação: Tânia Boy

Maquiagem: Tânia Boy

Cenário: Willyans Bailov e Tânia

Boy
Operador de Som: Maicon Paulucci

Sonoplastia: Willyans Bailov e

Roselaine Boy

Coreografias e Preparação

Corporal: Rosemeire Ghiqnatti

\section{ELENCO}

Adriana Cruz (Cacilda/Yara)

Ana Laura Furiqo (Marinete/Policial)

Camila Rocha (Rosa/Maria)

Carine Ramos (Dasdó/Mãe da

Noiua)

Danielli Machado

(Belinha/Policial/Santa)
Dieqo Kenit (Gaudencio/Demo)

Emanuelle Gomes

(Santinha/Fátima)

Ana Medeiros (Generosa/Policial)

Kelly Schiavinato (Mary

White/Madrinha/Lurdes)

Mateus Biazzo 


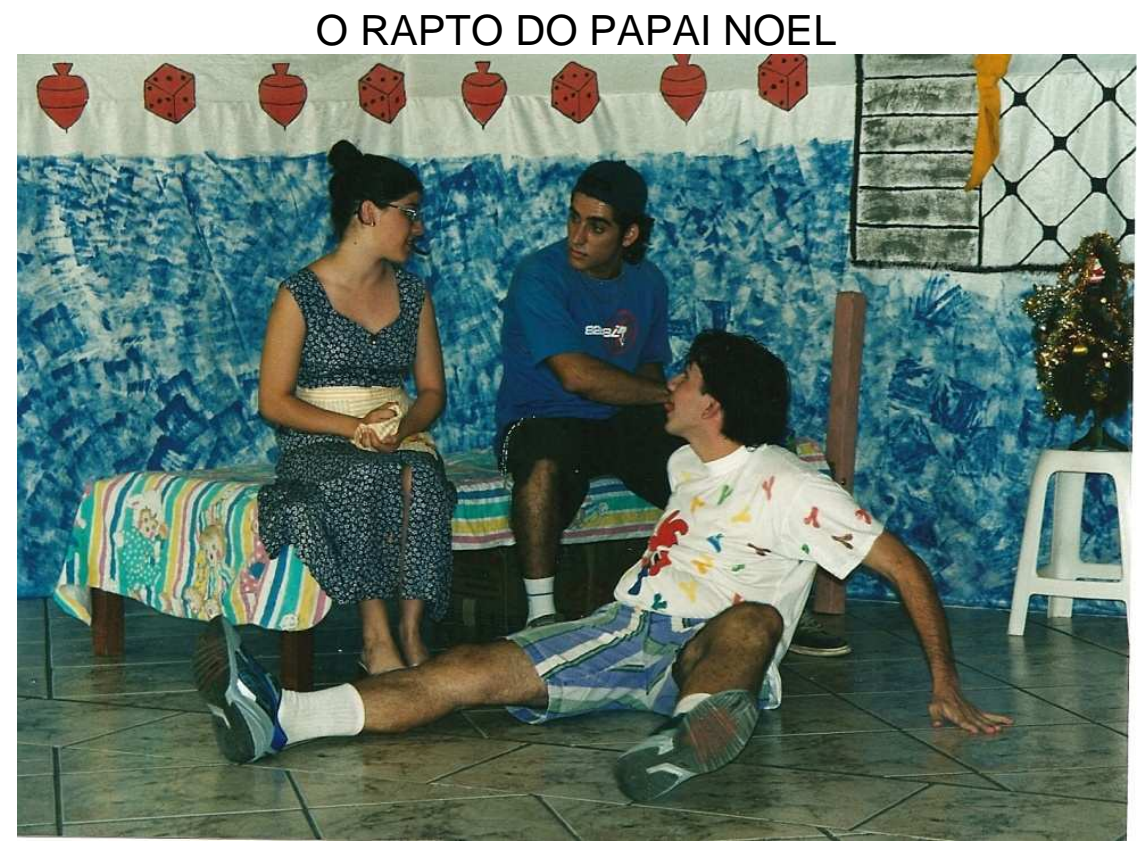

Autor: Francisco Antônio Neto (Chico Neto) e Moisés Rodrigo Ameno Grupo: Família Matula de Teatro

Escola: E.E. Professor Lauro Sanches

Cidade: Sorocaba

A Família Matula de Teatro traz para o palco um espetáculo para criança, com texto feito pelo próprio integrante do grupo, Chico Neto e que também faz a direção do espetáculo. Percebe-se o desenvolvimento do grupo através de sua participação no festival estudantil.

O grupo, neste festival, é orientado pelo professor Rubens Espírito Santo que, no início, era então o diretor, e nesta edição aparece como operador de luz. O espetáculo tem problemas de estrutura dramática, mas vem ganhando enquanto grupo e desenvolvimento artístico. O espetáculo revela uma preocupação de seus componentes com o público infantil e revela sua característica marcante: a força da comunidade sempre presente. 


\section{RELEASE}

A peça conta a história de dois irmãos que, há três Natais, não ganham presentes do Papai Noel. Infelizmente, a mãe Ihes dá a notícia de que ficarão mais um ano sem presente. Indignado, Zeca, um dos irmãos, vai dormir e sonha com o rapto do Papai Noel. Será sonho ou realidade?

Direção: Francisco Antônio Neto

\section{FICHA TÉCNICA E ARTÍSTICA}

Cenografia: Francisco Antônio Neto

Produção: Francisco Antônio Neto

Figurino: Alessandra Fernandes Prandi

Sonoplastia e Operador de Som: Robson Guimarães Faria

Iluminação e Operador de Luz: Rubens Espirito Santo

Maquiagem: Moises Rodrigo Ameno Cândido de Moraes

Contra-Regras: Marilene Fernandes e Patrícia Aparecida Antônio

$$
\text { ELENCO }
$$

Alessandra Fernandes Prandi (Papai Noel)

Ana Paula Antunes Santana (Mãe)

Francisco Antonio Melo (Zeca)

Moisés Rodrigo Ameno Cândido de Moraes (Juca) 


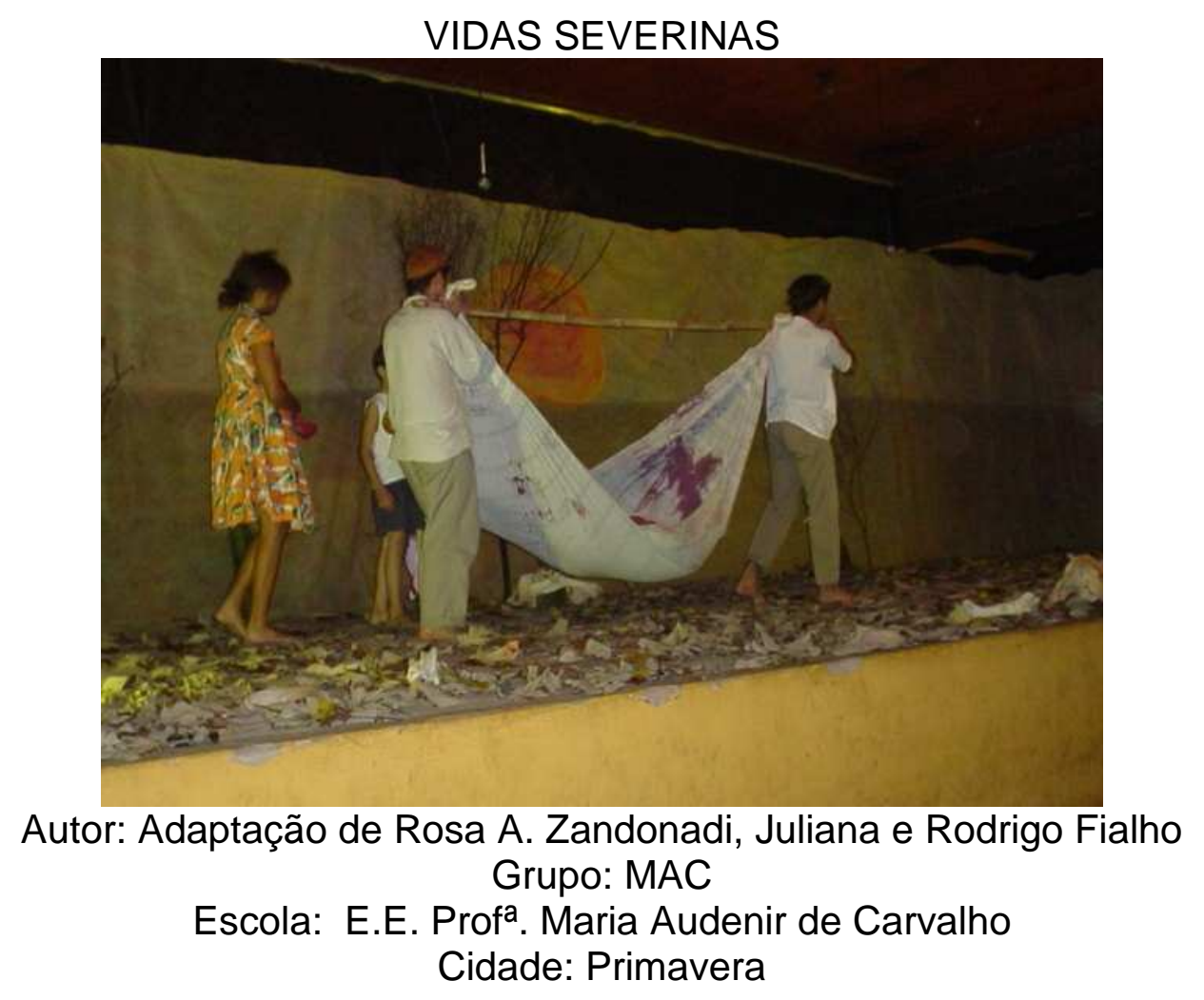

O espetáculo vem de uma cidade satélite chamada Primavera, que foi criada para atender a uma empresa, onde quase $98 \%$ dos moradores são nordestinos, daí a idéia de falar sobre os retirantes nordestinos. A aluna Rosa Augusta que estruturou o projeto conseguiu fazer com que este espetáculo acontecesse de maneira precária, mas com uma veracidade incrível, a ponto de emocionar muito a platéia. O prof. Clóvis Garcia que ressaltou a coragem e a determinação deste grupo que, pela primeira vez, vão e fazem teatro, chegando a se classificar no festival. O grupo, depois desta edição, nunca mais se inscreveu. Fui buscar notícias e fui informado que a Rosa havia se mudado de cidade e o grupo se acabara e que até então ninguém mais desenvolveu teatro naquela cidade. 


\section{RELEASE}

A peça é uma junção do livro Vidas Secas, de Graciliano Ramos, com o poema Morte e Vida Severina, de João Cabral de Melo Neto. O trabalho de criação e montagem remete à intertextualidade entre as duas obras. As personagens de Vidas Secas são inseridas no poema de João Cabral de Melo Neto e realizam a trajetória dos retirantes nordestinos.

\section{FICHA TÉCNICA E ARTÍSTICA}

Direção Rosa Augusta Zandonadi Oliveira, Valdir Boerghesan Filho e Tiago Diana Figurino, Coreografias, maquiagem e Produção da Silva Grupo UTAC Operador de Luz Marcos Aurélio F. Gomes Cenário Amanda Di Paula Rodrigues, Andréia Ribeiro da Rocha, Cleiton Gonçalves de

Simone de Araújo Gonçalves (Figurante/Cigana 2) Eliziane Aparecida de Oliveira (Figurante/Cantora)

Alisson M. Carvalho da Silva

(Figurante/Severino)

Paulo Henrique Lisboa da Silva (Figurante) Denis Fernando de C. Bezerra (Severino) Tamires Crescéndio Silva (Rezadeira) Jaqueline da Cruz Miranda (Figurante) Francielle Pereira (Figurante/Cantora) Amanda Di Paula Rodrigues (Figurante) Andréia Ribeiro da Rocha (Figurante) Kátia Vieira Nascimento (Cigana I) Rafaela Schenider da Silva (Figurante) Jucimarai dos Santos Oliveira (Sinhá Vitória) Douglas Alves da Cosia (Filho)
Sonoplasta Henrique Rodrigues Thomé Compositor André L. R. Meireles, Carlos Henrique F. Gomes e Henrique Rodrigues Thomé

\section{ELENCO}

Adriana A. Costa (Figurante)

Sharani Maria Manqueira Silva (Figurante)

Fabrício Costa (Fabiano)

Ana Carla Barbosa (Severino/ Figurante) llorayama S. Falcão (Figurante) André L. R. Meireles (Figurante) Carlos Henrique F. Gomes (Figurante) Adam Pereira Rodrigues (Fazendeiro/Figurante) Alba Valeria de Freitas da Silva (Figurante) Douglas Luiz Stransinski de Medeiros (Figurante) Karina Menezes Noronha (Figurante) Renata Diana da Silva (Figurante) 


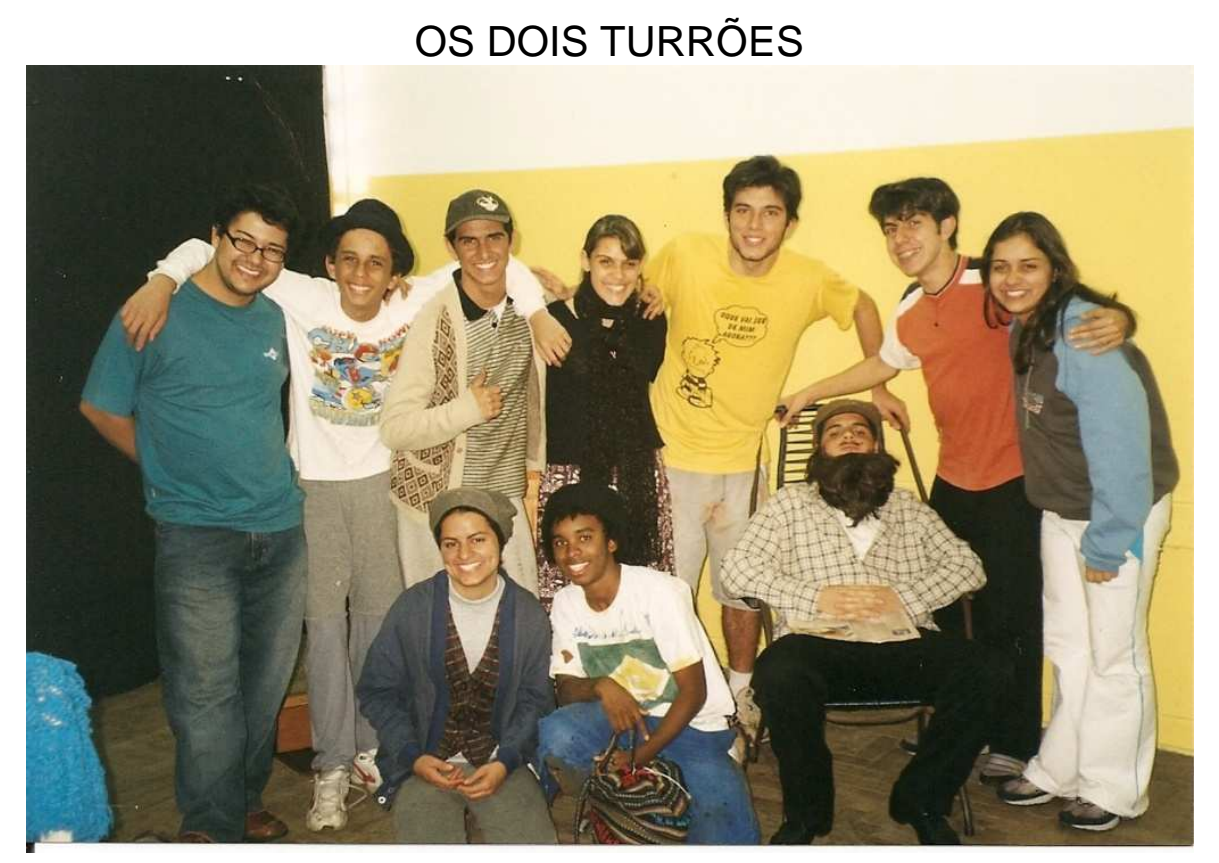

Autor: Tatiana Belinky

Grupo: Cia Pereirão de Teatro

Escola: E.E. Chico Pereira

Cidade: Tatuí

A Cia Pereirão de Teatro já esta na sua $3^{a}$ edição, participando sempre em um rodízio de alunos que se revezam entre direção e atuação. Os dois turrões, um espetáculo simples de boa qualidade artística, cumpre a função principal do festival: a disseminação das artes e isso jamais pode ser negado pela constante troca de função entre os integrantes do grupo. 


\section{RELEASE}

Enquanto José lê um jornal, Maria prepara dois pudins. Raios e trovões anunciam uma tempestade, fazendo com que uma porta abra e feche sucessivas vezes. Esse é o motivo de uma engraçada aposta entre os dois teimosos. Neste meio tempo, um grupo de viajantes faminto e friorento, ao ver a porta aberta, entra e desfruta da situação, tornado-se peça-chave na disputa entre os dois turrões.

\section{FICHA TÉCNICA E ARTISTICA}

Direção João Armando Fabbro Operadora de Som Patrícia de Assistente de Direção Tiago de Castro Almeida Tavares Leite Coordenação Geral André Luiz Contra-Regras Michel Mauarro de Miranda, Marcelo Gasparini, João Camargo Expressão Corporal Anelissa Baldasseirine, Paola Bertolini, Sara Rivera e Mari Pinheiro Fructuoso Cenário, Figurino e Produção Cia Divulgação e Fotos Prof ${ }^{a}$. Selma Regina Aragão Pereirão de Teatro Maquiagem Marilia Teixeira e Professores Responsáveis pelo Grupo Jackeline Gabriel Cardoso Sonoplastia Júlio Carrara Anelissa Fructuoso, Mirela Arena e Esmeralda da Silva Diretora da EE "Chico Pereirão" Iluminação e Operador de Luz Tiago de Castro Leite Juliana Maria Labronici Baiardi Realização Cia Pereirão de Teatro -

\section{ELENCO} EE "Chico Pereirão"

Erick Sotero (José)

Marília Teixeira (Maria)

Elton Pinheiro (Viajante) Jackeline Gabriel Cardoso (Viajante)

Bruno da Silva Amaral (Viajante)

Fernando Henrique Casalunqa (Viajante). 


\section{LENDAS - O PENTÁGONO GREGO}

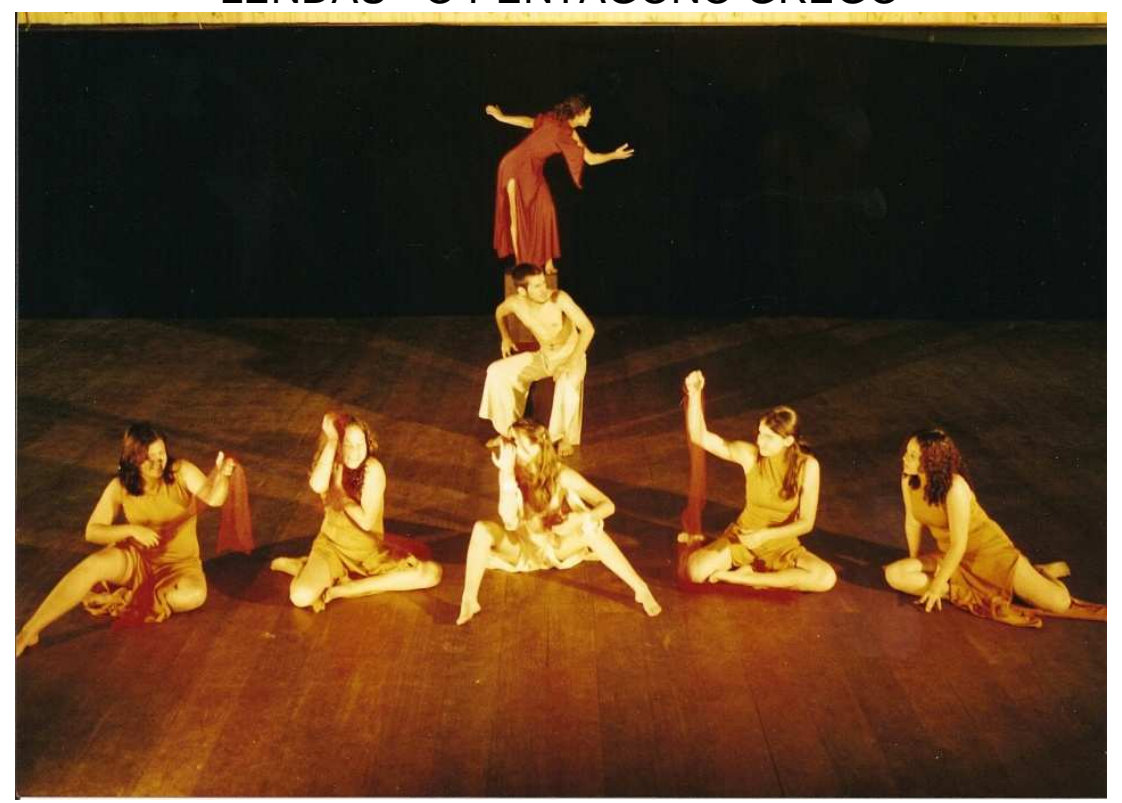

Autor: Adaptação de Juliano Casimiro

Grupo: Cia de Teatro UTA

Escola: E.E. Dr. Afonso Vergueiro

Cidade: Salto

O espetáculo que vem da cidade vizinha, Salto de Pirapora, chega a impressionar pela sua cenografia e pela grandiosidade do espetáculo. Com uma direção impecável, o grupo desenvolve a história de maneira agradável. Durante o debate, alguns questionamentos foram levantados, e se percebeu que o grupo não estava muito seguro e que havia alguns problemas internos, que poderiam talvez levar ao fim do grupo. 


\section{RELEASE}

As personagens do espetáculo são textos que lutam para completar a saga destinada por seus próprios "fantasmas" - fatos que circundam 0 inconsciente coletivo e permanecem em cada ser - narrando o retorno de Odisseu a Ítaca, após a Guerra de Tróia e o posterior morticínio dos pretendentes à mão de sua irrepreensível esposa.

FICHA TÉCNICA E ARTÍSTICA

Direção e Adaptação Juliano Casimiro

Assistente de Direção Jane Kastorsky de Souza

Maquiagem e Cabelo Bida Marcello e Karen Costa

Assessoria Publicitária Maria Helena

Assistente de Produção Sil Oliveira

Operador de Som Gérica Santos

Operador de Luz Juliano Casimiro e Tadeu Fonseca

Cenógrafo Dorival de Souza

Angélica Leme (Cerva)

Denis Manzato (Hermes)

Denise Oliveira (Atena)

Flávia César

(Euricléia/Nausicaa/Cerva)

Gisele Berenguel

(Penélope/Calipso/Areta)

Ivan Kastorsky (Egípcio/Eumeu)

Ivan Nicola (Zeus)

\section{ELENCO}

Jackson Emílio (Telêmaco/Alcínoo)

João Paulo dos Anjos

(Prometeu/Poseidon/Tirésias)

Lays Cardinali (Circe/Cerva)

Marcelo Moraes (Antinoo)

Nalalia LazariNni (Hera/Cerva)

Rafaela Ayres (Anticléia/Cerva)

Vinícius Rostelato (Odisseu) 
FUI NO MOINHO BUSCAR... MÓ

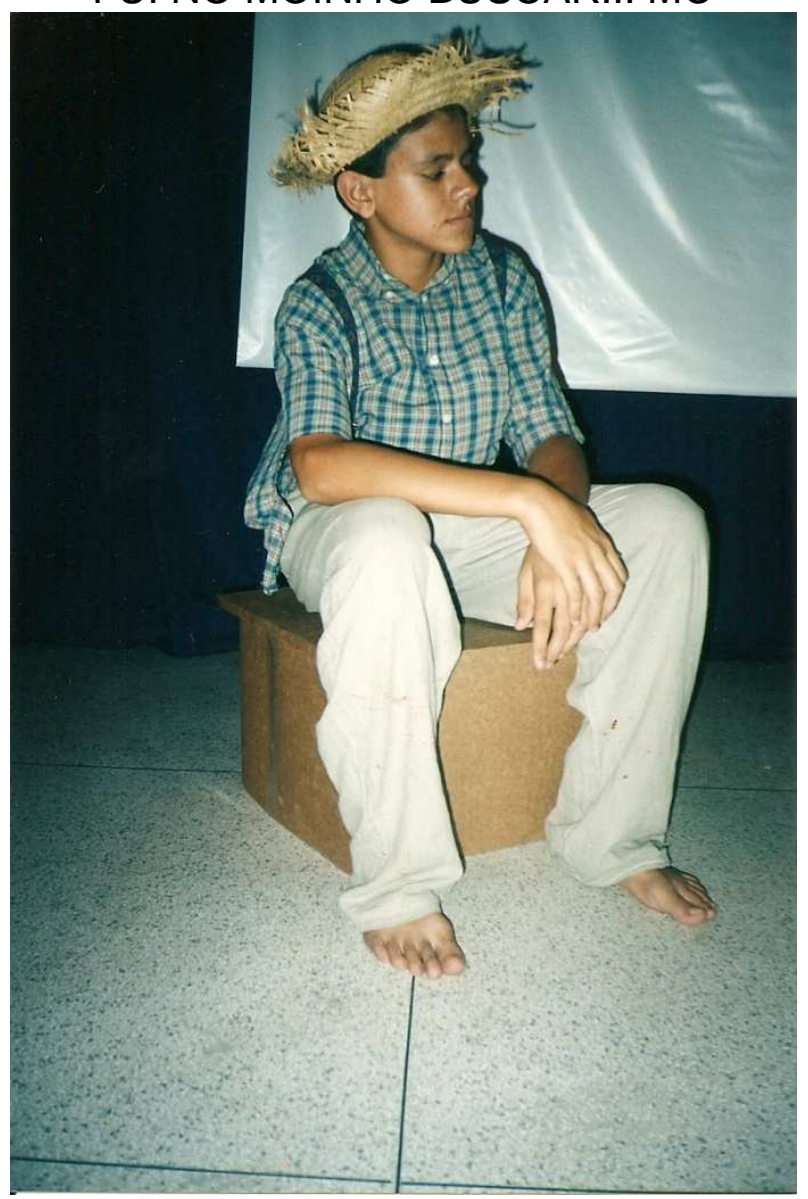

Autor: Gabriela Rabelo

Grupo: Companhia das Artes Dramáticas

Escola: E.E. Prof. Daniel Verano

Cidade: Votorantim

O espetáculo com direção de Julio Carrara, que se fez presente em outras edições, vem com uma atuação um pouco sofrível, por motivos que ele próprio levantou durante o debate, como por exemplo, a escola restringiu os ensaios para um dia na semana e outros empecilhos. O grupo, que já tem uma estória marcante no festival, mostra-se desestimulado, por conta de problemas enfrentados com a estrutura da escola.

\section{RELEASE}

O espetáculo narra a história de um garoto com dificuldade de viver em um mundo onde os sonhos não têm lugar. Dessa maneira, procura aceitar, sem discutir, as ordens dos outros. Sua mãe pede para que vá ao moinho buscar fubá. Durante o caminho, depara-se com pessoas que estão às voltas com 
seus problemas, confundindo a cabeça do menino, que não se lembra mais o que fora comprar.

\section{FICHA TÉCNICA E ARTÍSTICA}

Direção, Iluminação e Sonoplastia: Júlio Carrara Cenografia Edivaldo de Góes Figurino e Maquiagem Ana Paula de Oliveira Operador de Retroprojetor Carla Doles

\section{ELENCO}

Matheus Rodrigues (Lauro)

Ana Paula Oliveira (Mãe de Lauro/Dona de Casa/Mulher) Edivaldo Góes (Lavrador/ Moleiro) 


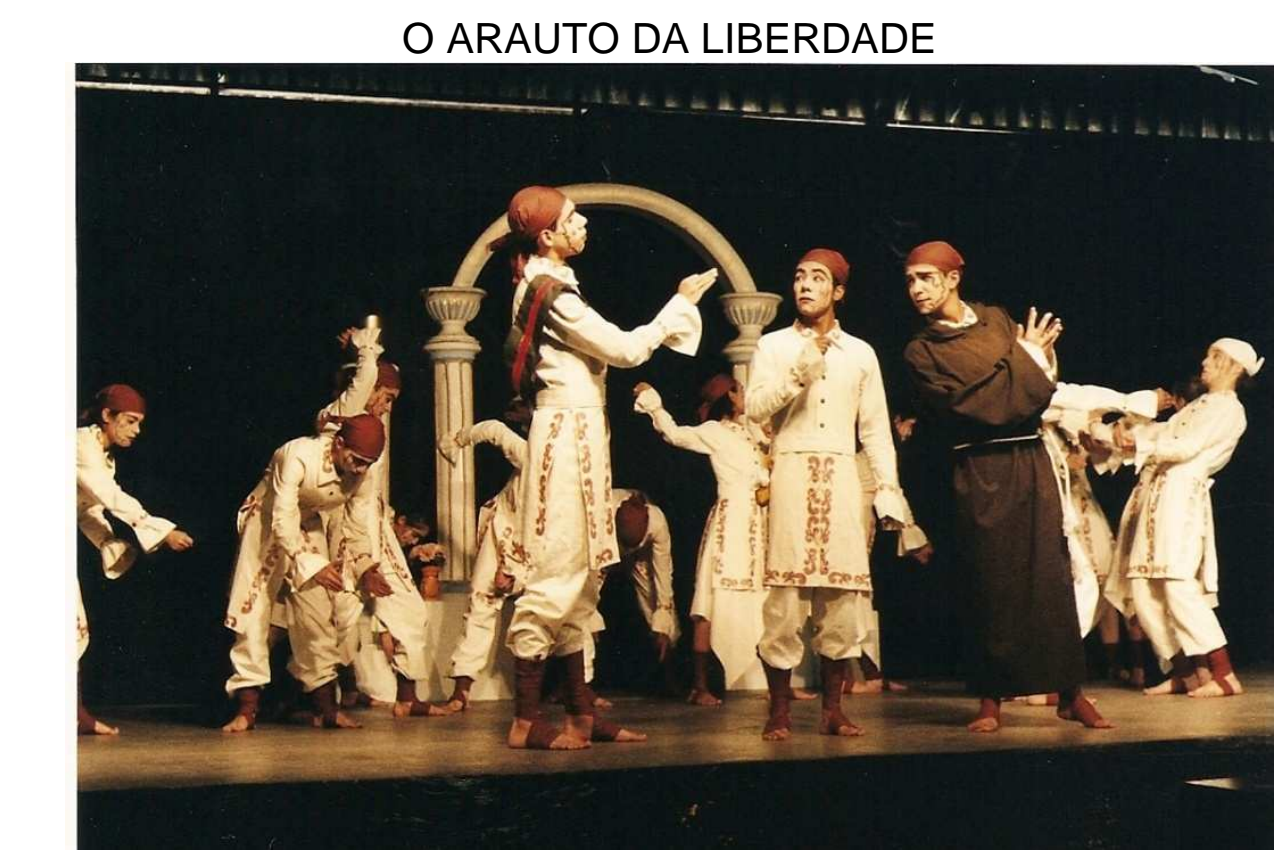

Texto: Adaptação da peça Arena Conta Tiradentes de Augusto Boal e Gianfrancesco Guarnieri

Grupo: Tal \& Pá

Escola: E. E. Maria Augusta de Ávila

Cidade: São Paulo

A comunidade do bairro Artur Alvim, de São Paulo, mais uma vez coloca um belíssimo espetáculo no palco, cito comunidade, pois o trabalho desenvolvido pela professora artista Valéria de Oliveira é de total envolvimento com a comunidade e escola. O espetáculo encanta a todos os presentes pela capacidade que o grupo tem de tratar com o tema, os alunos atores deslizam pelo palco, fazendo um grande acontecimento teatral. A professora Valéria que, até então dividia a direção, aparece no comando, sozinha, como professora e diretora. 


\section{RELEASE}

Texto inspirado na peça Arena Conta Tiradentes, escrita e encenada pelo Teatro de Arena em 1967. O Grupo Tal\&Pá celebra 10 anos recontando os eventos que marcaram a Conjuração Mineira, em 1789, buscando referências comuns ao momento social e político no qual o Brasil se encontra nos dias de hoje. "Liberdade - essa palavra que o sonho humano alimenta: que não há ninguém que explique e ninguém que entenda!" (Cecília Meireles)

\section{FICHA TÉCNICA E ARTÍSTICA}

Direção e Produção Valéria de Oliveira Sonoplastia, Produção Musical e Operadora de Som Soraya de Oliveira

Coordenação Técnica, Iluminação e Operadora de Luz Carina Diana

Preparação Corporal Carol Silva e Xica Lisboa Coreografia Ariovaldo Júnior

Cristiana Fabricio (Coringa)

Lúcia Sallete Leão Nunes (Coringa)

Roberta A. Quirino Pinto (Arauto/Escrivão)

Marcelo H de Araújo (Cunha Menezes/ $1^{\circ}$ Padre/

Macedo)

Rafael da Silva Fabrício (Clérigo/ Bêbado/ Garimpeiro/

Carcereiro)

Jones Marinho de Oliveira (Domingos) Rodrigo S. TH.

Rodrigues (Rolim)

Eduardo de 0 . Carvalho (Tiradentes)

Aparecida Luciana dos Santos (Mônica/Rainha)

Robson Quirino Salvador (Padre Toledo/Taverneiro)

Carolyn Amanda F. da Silva (Antonia)

Anderson Luiz C. F. Miranda (Maciel)

Laís Alves da Silva (Sandra)
Cenografia e. Maquiagem Grupo Tal\&Pá

Figurinos Rodrigo Serradura e José de Lima Contra-Regras Camilla Cristiane, Alexandre Naves, Walcir Alves, Adriano Lisboa, Helena de Oliveira, Juliana Requena, Robson Job, Reinaldo Soledade, Danu Garcia e Cláudio Júnior

\section{ELENCO}

Reinaldo S. da Soledade (Barbacena)

Antônio C. V. Leão Nunes (Gonzaga)

Gisele Xavier da Silva (Marilia)

André Abbenante (Alvarenga)

Suellen Santana Silva (Bárbara)

Alairton Lopes (Cláudio)

Ariovaldo Ramos Júnior (Silvério)

Robson Job de S. Santos (Tenente Francisco Freire)

Cássia de Freitas André (Gertrude/Mulher do Povo)

Renata Ferreira Costa (Inácia/Mulher do Povo)

Amaraisa Gonçalves (mulher do Povo)

Bruna da Graça Fonseca (mulher do Povo)

Joseane N. S. de Carvalho (mulher do Povo)

Leiliane Silva do Vale (mulher do Povo)

Renata Aparecida da Silva (mulher do Povo) 


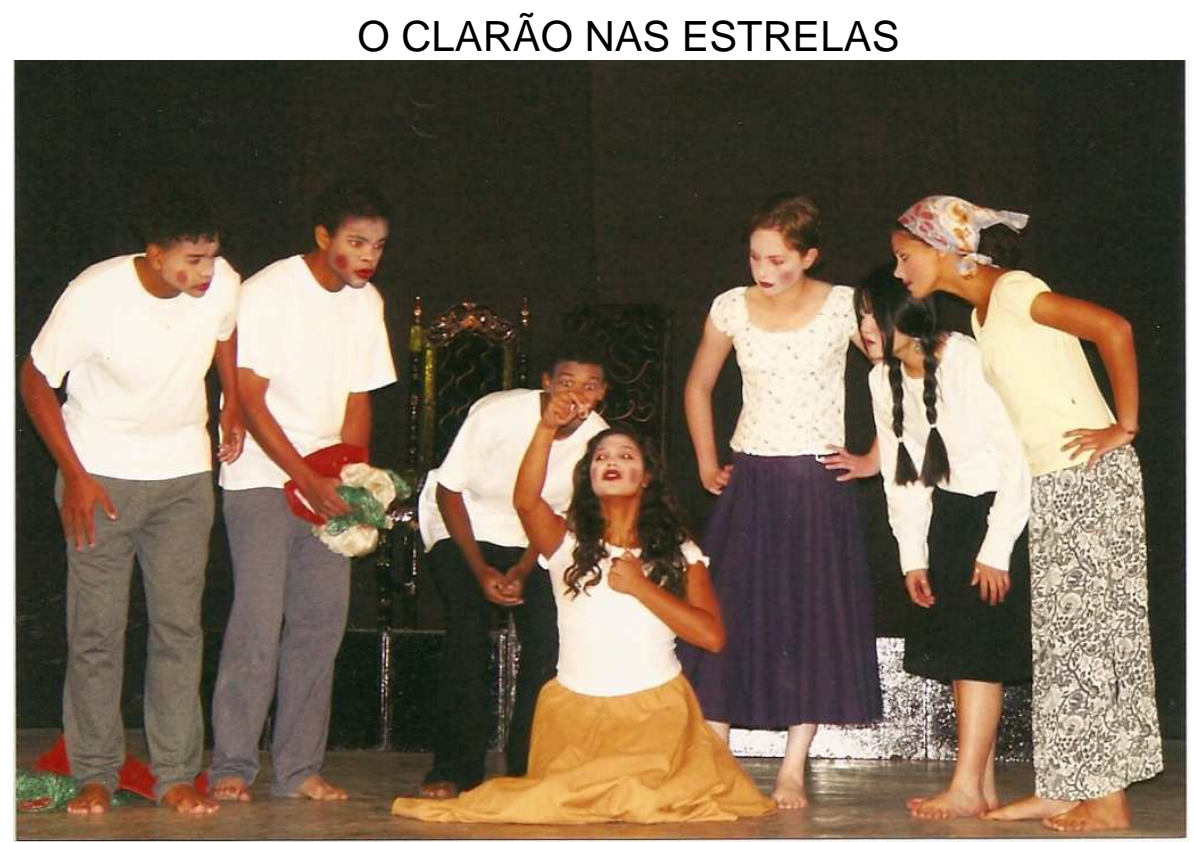

Autor: Vladmir Capela

Grupo: UNI-DUNI-TE

Escola: E.E. Maria Augusta de Ávila

Cidade: São Paulo

O grupo vem de uma desinência do Tal\&Pá, trazendo uma nova trajetória, que é espetáculo para criança. A professora artista Patrícia Nepomuceno, que até então trabalhava em conjunto com a professora artista Valéria de Oliveira, assume o comando deste grupo e constrói este espetáculo, que vem cheio de erros e dá a impressão de não ser assertivo no que se refere a um teatro para criança. Foi muito contestado pela comissão julgadora, e esta foi a única vez que o grupo se fez presente no festival. 


\section{RELEASE}

A peça é um conto de fadas sobre o poder que o amor puro e verdadeiro tem de libertar as almas aprisionadas a acabar com seu sofrimento. Conta a história de um príncipe que fora enfeitiçado pelos pais. Nesse cenário, surge uma menina órfã que é levada ao castelo e, mesmo sendo maltratada pela rainha, consegue quebrar o feitiço e libertar o príncipe.

\section{FICHA TÉCNICA E ARTÍSTICA}

Direção Geral Patrícia Nepomuceno e José Wagner Iluminação George Renato Sonoplastia Ivan Pophets Contra-Regra Karina Vianna Coreografia Patrícia Nepomuceno Maquiagem e Figurino O Grupo Cenário e Trilha Sonora José Waqner

Cristiano Ramos (Rei) Priscila Celi (Rainha) Renato Ribeiro (Príncipe) Aline Fernandes (Filaria) Carolina Scalabrini (Elisabethe/Mãe da Maria) Michelle Roseling (Gorethe) Camila Bernardes (Liethe) Daniela Dalacqua (Margarethe) Karen Natalia (Bernadete) Amanda Godoy (Camponesa)

\section{ELENCO}

Vanessa Cristina (Camponesa) Karina Mayumi (Camponesa) Ivanildo Araújo (Camponês/Intérprete) Luiz Fernando (Camponês/Dr. Chinês) Jean Assumpção (Camponês/Dr. Francês) Camila Zaramella (Dra. Italiana) Plinio de Paula (Dr. Afegão) 


\section{MAIS QUERO UM ASNO QUE ME CARREGUE DO QUE UM CAVALO QUE ME DERRUBE}

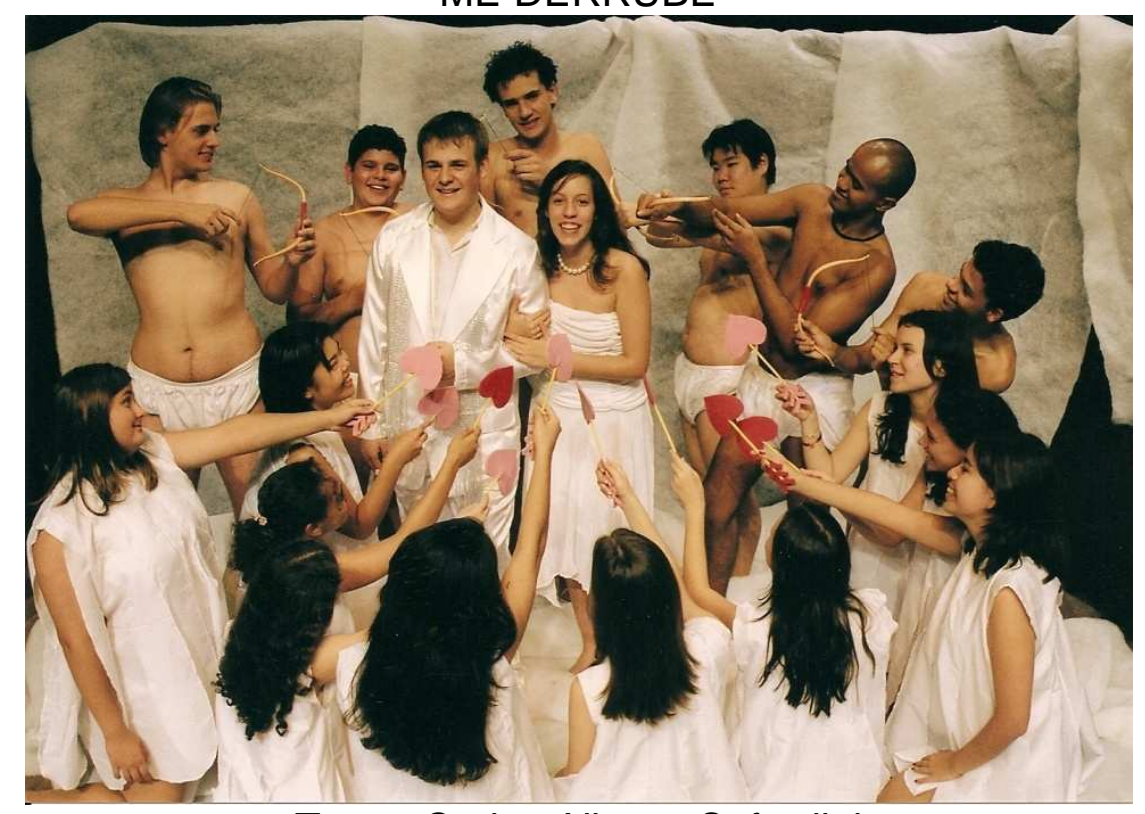

Texto: Carlos Alberto Sofredini

Grupo: Grupo Teen de Teatro

Escola: Colégio Santo Agostinho Cidade: São Paulo

Um espetáculo que fez emocionar do começo ao fim com direção de Pámela Paz e Fábio Hilst. O espetáculo vem com o mesmo grupo de espetáculo passado com um grande amadurecimento tanto da direção como dos atores, um ponto favorável no espetáculo foram as músicas de Gilson Faria. O grupo do teatro Santo Agostinho também já esta percebendo e levantando a importância da passagem por este festival. Durante o debate a comissão ressaltou os pontos positivos e foram muito elogiados. 


\section{RELEASE}

O espetáculo conta a história de uma jovem que procura desesperadamente um noivo para se casar, vizinhas, amigos e parentes mobilizam-se para conseguir um marido para ela. Após desprezar um pretendente cafona e desajeitado, a jovem conhece um rapaz alto e forte com quem se casa. Infelizmente, o casamento é um inferno, terminando na trágica morte de seu marido pela amante.

\section{FICHA TÉCNICA E ARTÍSTICA}

Direção Geral e Figurinos Pámela

Paz e Fábio Hilst

Letras Adicionais: Gilberto Andreotti

e Gilson Faria

Música, Direção Musical, Cenografia e Design de Som:

Gilson Faria

Design de Luz Fábio Hilst

Coreografia Janaina Castro

Rhaissa Bittar (Inês Pereira)

Larissa Gude (Dona Clara)

Camila Yumi (Dona Leonor Vaz

D'Almeida)

Nayara Araújo (Festeira I)

Rebeca Damião (Festeira 2)

Ana Carla Fonseca (Festeira 3)

Pablina Araújo (Luzia)

Bárbara TaVares (María)

Inara Santos (Carmen)

Henrique Faria (Pedro)
Direção de Palco Bruna Satiko

Operação de Som Humberto Lin

Operação de Luz Marcos Melim

Maquiagem e Penteados O Grupo

Fotos Aldine Paiva

Contra-Regras Rafael Souza, Cíntia Suzuki, Noelle Ruas e Sofia Junqueira

\section{ELENCO}

Tiago Larenas (João Basílio/John

Bharazz)

Maurício Alonso (Speaker)

Yuri Saito (Corista 1/Garoto

Propaganda I)

Raul Sanchez (Corista 3/Dono do motel)

Daniella Faria (Claque I)

Brenno Fonseca (Claque 2)

Patrícia Quero (Garota Propaganda) 


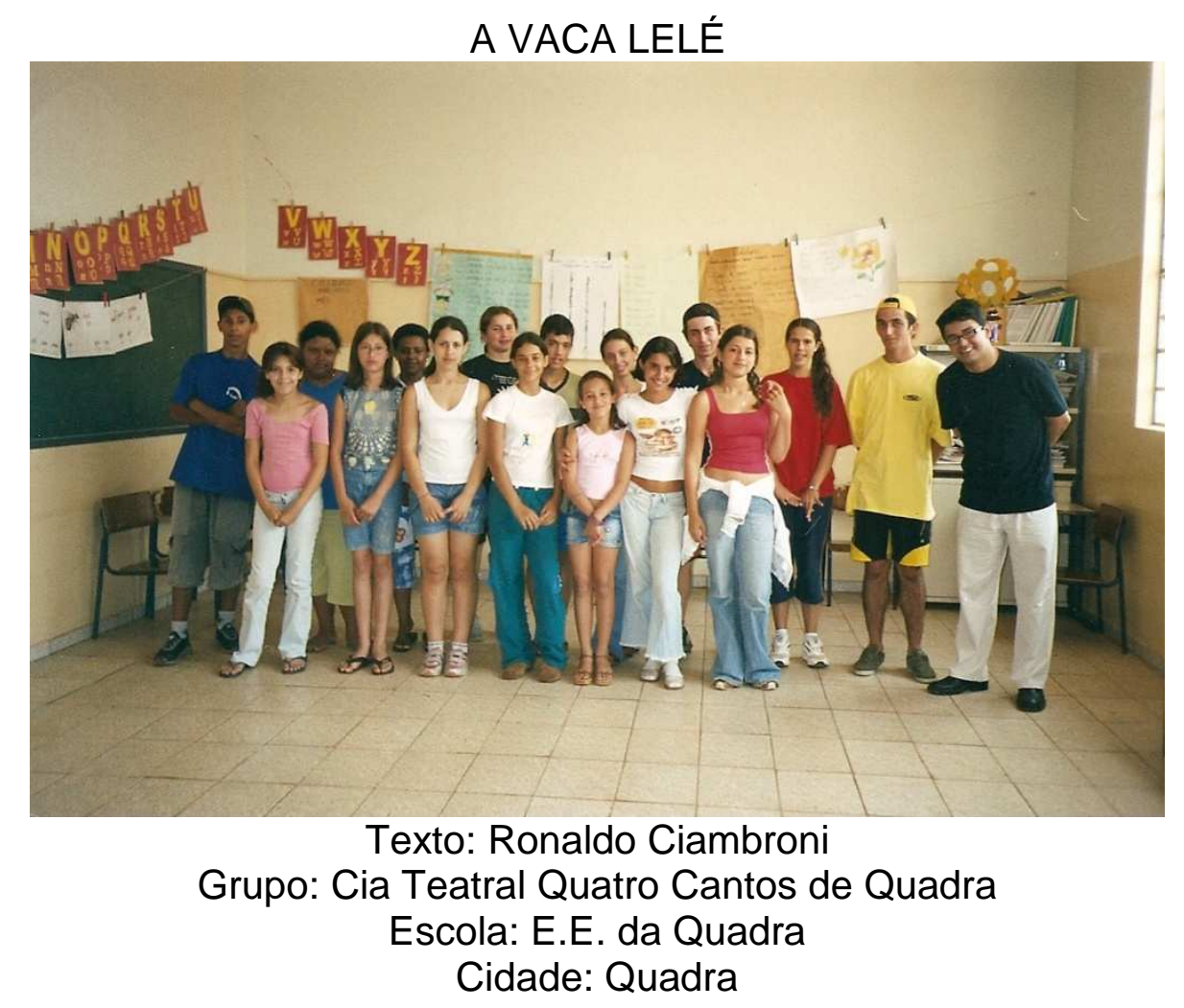

A Cia Quatro Cantos de Quadra vem com o espetáculo A Vaca Lelé, de Ronaldo Ciambroni, com direção do professor artista André Camargo. O espetáculo vem bem acabado, com uma direção acertada. $O$ trabalho surgiu a partir de uma oficina que foi dada na cidade; o elenco é totalmente formado por crianças o que dá um enriquecimento maior para o feito teatral. A cidade não tem uma tradição em teatro e não existe outro grupo que faça teatro na cidade, onde a maioria dos habitantes é da zona rural. Devido a isso, durante o espetáculo nota-se a característica do viver caipira dos alunos atores, o que em momento nenhum desfavorece a interpretação como também o espetáculo. 


\section{RELEASE}

O espetáculo é um texto lírico com tom de fábula, que conta a história de Matilde, uma vaquinha que se afasta de suas companheiras para se aventurar pela fazenda, conhecer novos lugares, fazer novos amigos e realizar seu grande sonho de voar. Protagoniza situações que falam sobre a liberdade e a não-violência, proporcionando e estimulando a reflexão sobre os perigos da intolerância com aquilo que é diferente ou desconhecido.

\section{FICHA TÉCNICA E ARTÍSTICA}

Direção Geral, Iluminação e Sonoplastia: André Luiz Camargo

Assistente de Direção: Silvana Geraldini Cenografia e Adereços: Alcides Júnior Figurino e Adereços: Sérgio Franco e Edna Geraldini Maquiagem: lida Camargo e Silvana Geraldini Preparação vocal: Edmo Perandim e André Camargo

Preparação Corporal e Interpretação: André Luiz Camargo e Orleu Fava Contra-Regras: Jaqueline Cardoso, Marília Teixeira, João Fabbro, Tiago Leite, Erick Sotero,

Vanessa Soares (Cigarra)

Tamires Ribeiro Lourenço (Pardal)

Thais Aparecida Soares (Vaga-lume)

Edivana Mendes Vieira (Vaga-lume)

Ana Caroline Preste de Oliveira (mosca)

Caroline Soares de Souza (Vaga-lume)

Paloma Aparecida Soares (Pintinho)

Thais Aparecida Lobo (Vaca Lelé)

Jaqueline Mariane Paes Coelho (Galinha)

Sheila Pedroso (Vaga-lume)

Aline Espinosa Rodrigues (mosca)
Elton Pinheiro, Fernando Casalunqa, Patrícia Almeida e Bruno Cardoso

Equipe de Cenografia, Iluminação, de Maquiagem

e Equipe Técnico-Artistica: Cia Teatral Quatro

Cantos de Quadra

Prefeito Municipal: Oscar Dias

Secretário da Educação: Luciano César de Toledo

Diretor da EE da Quadra Roberto

Diretor da Escola Municipal: José Rubens

Vice-Diretor: Gonzaqa

Coordenadora Pedagógica: Cleide

Professora Assistente: Siluana Qeraldini

Educidora Profissional: llida Camargo

\section{ELENCO}

Alcides Baldassim Júnior (Touro)

Darlison Mariano de Barros (Espantalho)

Érika Janaina de Camargo (Cigarra)

Mariana de Oliveira (mosca)

Vânia Aparecida Antunes (Vaga-lume)

Daiane Ferreira Menezes (Pintinho)

Jeferson Ricardo da Silva Moura (Fazendeiro)

Fabiano Rodrigues Moura (Fazendeiro)

Thamires Elizabeth da Silveira (Pintinho)

Willian Pedroso (Fazendeiro)

Ingrid de. Almeida Souza (Vaga-lume) 

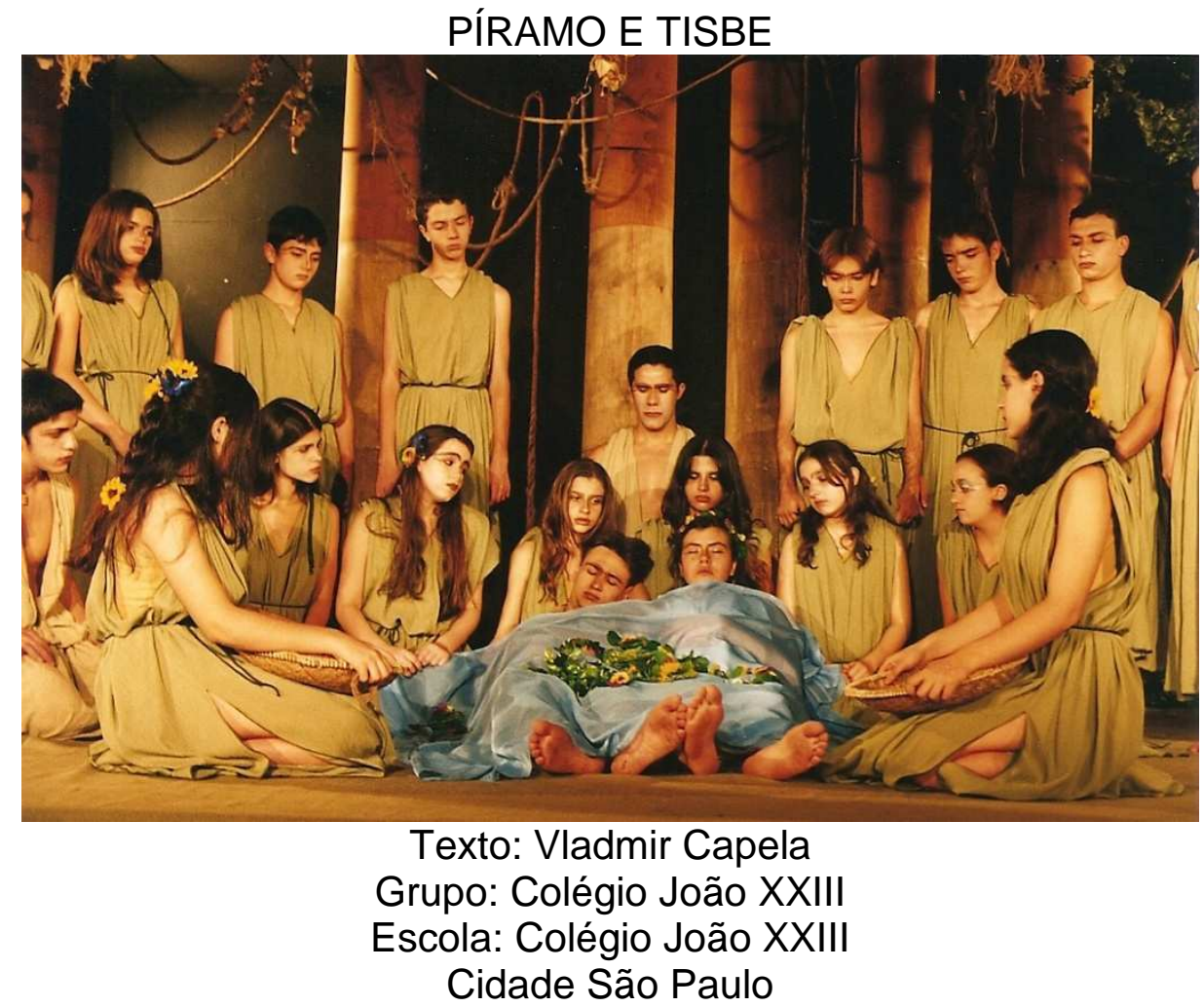

É a primeira participação do grupo neste festival. O espetáculo vem com uma produção expressiva, mas não consegue uma grande apresentação. $O$ professor artista Eduardo Hajjar desenvolve aulas de teatro no colégio João XXIII. Durante o debate houve uma vasta explanação de seu processo de trabalho na escola junto com o grupo, ele mantém vários espetáculos, preparados para as apresentações que surgem, durante o seguir dos anos trocam-se os alunos das montagens que já foram feitas. 


\section{RELEASE}

As religiões da Grécia desapareceram, mas o legado de seus mitos e heróis continua presente até os dias de hoje. As dores e paixões que cercam estas histórias de amor aparecem em Píramo e Tisbe, fonte de inspiração para William Shakespeare escrever Romeu e Julieta e Sonhos de uma noite de verão. Os contos presentes no espetáculo preparam psicologicamente 0 espectador para o trágico acontecimento entre os jovens Píramo e Tisbe.

\section{FICHA TÉCNICA E ARTÍSTICA}

Direção Geral, Cenografia e Iluminação: Eduardo Hajjar Cenotécnico: Edgar de Abreu Figurino: Dirce Regina de Mula Maquiagem: Ana Paula Barbosa Federicci

Danilo Madjarof Sertorio (Píramo) Fernanda Marcassa Araújo (Tisbe) Erika Prísel Marques (Sibila) Rodrigo Gomes Telli (Narciso/Camponês) Jéssica Fernandes de Carvalho (Eco/Dóris/Camponesa)

Rafael Camperlingo B. da Costa (Orfeu/Camponês) Gustavo Henrique S. de Lima (Hades/Camponês) Andréia Perusi (Láquisis-Parca/Camponesa) Léva Ht. Ferreira (Cloto-Parca/Camponesa) Aline Garcia (Pandora/Átropos-Parca/Camponesa) Isabela Lessa (Perséfone/Camponesa)

Gabriela Ravanhani

(Rãmona/mênades/Camponesa)

Marcelo Rizzo (Pireu/Camponês)
Técnico de Som: Antônio Marcelo França

Mixagem: Flávio Cristiano Martins Produção: Colégio João XXIII, Circulo de Circulo de Trabalhadores Cristãos de Vila Prudente

\section{ELENCO}

Raquel Hila Gimenez (Ninfa/Ménades/ Camponesa) Thais Ferreira Rodrigues

(Euridice/Ninfa/Camponesa) Débora Fernandes Francisco (Ninfa/ Camponesa) Mariana Hila Gimenez (Ninfa/Camponesa/Leoa) Natália Ravanhani (Ninfa/Camponesa/Menina) Renato Donizete Silva (Caronte/Campones) Danilo Cheida (Camponês) Enzo Wartucci (Camponês) Raphael Oliveira Lima (Camponês) Rodrigo Coracini (Camponês) Fabiano Ferreira Leocadio (Camponês) Mirella Komalski Ferraz (Ninfa/Camponesa) Karina Gardini Ciarvolo (Ninfa/ Menadês/ Camponesa). 
PREMIAÇÃO CATEGORIA INFANTIL

\begin{tabular}{|c|c|c|c|c|c|c|}
\hline & $\begin{array}{l}\text { HISTORRIAS } \\
\text { ESCONDIDAS } \\
\text { ENTRE RIOS } \\
\text { E MARES }\end{array}$ & $\begin{array}{l}\text { O RAPTO DO } \\
\text { PAPAI NOEL }\end{array}$ & A VACA LELÉ & $\begin{array}{c}\text { OS DOIS } \\
\text { TURRỐES }\end{array}$ & $\begin{array}{c}\text { FUINO } \\
\text { MOINHO } \\
\text { BUSCAR... } \\
\text { MÓ }\end{array}$ & $\begin{array}{c}\text { A CLARÃO } \\
\text { NAS } \\
\text { ESTRELAS }\end{array}$ \\
\hline $\begin{array}{c}\text { ATOR } \\
\text { REVELAÇÃO }\end{array}$ & & & & $\begin{array}{l}\text { BRUNO DA } \\
\text { SILVA } \\
\text { AMARAL }\end{array}$ & & \\
\hline $\begin{array}{c}\text { ATRIZ } \\
\text { REVELAÇÃO }\end{array}$ & & & $\begin{array}{c}\text { THAIS } \\
\text { APARECIDA } \\
\text { LOBO }\end{array}$ & & & \\
\hline $\begin{array}{l}\text { COADJUVANTE } \\
\text { MASCULINO }\end{array}$ & & & & $\begin{array}{l}\text { ELTON } \\
\text { PINHEIRO }\end{array}$ & & \\
\hline $\begin{array}{l}\text { COADJUVANTE } \\
\text { FEMININO }\end{array}$ & & & & & $\begin{array}{l}\text { ANA PAULA } \\
\text { OLIVEIRA }\end{array}$ & \\
\hline CENOGRAFIA & & & & & & $\begin{array}{c}\text { JOSÉ } \\
\text { WAGNER }\end{array}$ \\
\hline ILUMINAÇÃO & & & & & & $\begin{array}{l}\text { GEORGE } \\
\text { RENATO }\end{array}$ \\
\hline FIGURINO & $\begin{array}{l}\text { ELAINE } \\
\text { BUZATO }\end{array}$ & & & & & \\
\hline MAQUIAGEM & $\begin{array}{l}\text { ELAINE } \\
\text { BUZATO }\end{array}$ & & & & & \\
\hline SONOPLASTIA & & $\begin{array}{c}\text { ROBSON } \\
\text { GUIMARÃES }\end{array}$ & & & & \\
\hline DIREÇÃO & & & & $\begin{array}{l}\text { JOÃO } \\
\text { ARMANDO } \\
\text { FABRO }\end{array}$ & & \\
\hline MELHOR ATOR & & & & & & $\begin{array}{l}\text { RENATOO } \\
\text { RIBEIRO }\end{array}$ \\
\hline $\begin{array}{l}\text { AMELHOR } \\
\text { ATRIZ }\end{array}$ & & & & $\begin{array}{l}\text { MARILIA } \\
\text { TEIXEIRA }\end{array}$ & & \\
\hline $\begin{array}{c}\text { MELHOR } \\
\text { ESPETÁCULO }\end{array}$ & & & & $\begin{array}{c}\text { OS DOIS } \\
\text { TURRÕES }\end{array}$ & & \\
\hline $\begin{array}{c}2^{2^{\circ}} \text { MELHOR } \\
\text { ESPETÁCULO }\end{array}$ & & & & & & $\begin{array}{l}\text { CLARÃO NAS } \\
\text { ESTRELAS }\end{array}$ \\
\hline
\end{tabular}


PREMIAÇÃO CATEGORIA ADULTO

\begin{tabular}{|c|c|c|c|c|c|c|}
\hline & $\begin{array}{l}\text { MEU CORDEL } \\
\text { ESTRADEIRO }\end{array}$ & $\begin{array}{c}\text { VIDAS } \\
\text { SEVERINAS }\end{array}$ & $\begin{array}{l}\text { LENDAS - O } \\
\text { PENTAGONO } \\
\text { GREGO }\end{array}$ & $\begin{array}{c}\text { O ARAUTO } \\
\text { DA } \\
\text { LIBERDADE }\end{array}$ & 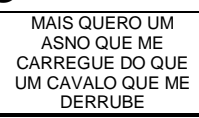 & $\begin{array}{l}\text { PíRAMO E } \\
\text { TISBE }\end{array}$ \\
\hline $\begin{array}{l}\text { ATOR } \\
\text { REVELAÇÃO }\end{array}$ & & & $\begin{array}{l}\text { JACKSON } \\
\text { EMÍLIO }\end{array}$ & & & \\
\hline $\begin{array}{l}\text { ATRIZ } \\
\text { REVELAÇÃO }\end{array}$ & & & & & CAMÍLA YUMI & \\
\hline $\begin{array}{l}\text { COADJUVANTE } \\
\text { MASCULINO }\end{array}$ & & & & $\begin{array}{l}\text { ARIOVALDO } \\
\text { RAMOS JR. }\end{array}$ & & \\
\hline $\begin{array}{l}\text { COADJUVANTE } \\
\text { FEMININO }\end{array}$ & & & & & $\begin{array}{l}\text { INARA } \\
\text { SANTOS }\end{array}$ & \\
\hline CENOGRAFIA & & & $\begin{array}{l}\text { DORIVAL DE } \\
\text { SOUZA }\end{array}$ & & & \\
\hline ILUMINAÇÃO & & & & & & $\begin{array}{c}\text { EDUARDO } \\
\text { HAJJAR }\end{array}$ \\
\hline FIGURINO & & & & & $\begin{array}{c}\text { PÁMELA PAZ } \\
\text { E FÁBIO } \\
\text { HILST }\end{array}$ & \\
\hline MAQUIAGEM & & & & & & $\begin{array}{l}\text { ANA P. B. } \\
\text { FEDERICE }\end{array}$ \\
\hline SONOPLASTIA & & & & & $\begin{array}{l}\text { GILSON } \\
\text { FARIA }\end{array}$ & \\
\hline DIREÇÃO & & & $\begin{array}{l}\text { JULIANO } \\
\text { CASSIMIRO }\end{array}$ & & & \\
\hline MELHOR ATOR & & & & $\begin{array}{l}\text { EDUARDO } \\
\text { CARVALHO }\end{array}$ & & \\
\hline $\begin{array}{l}\text { AMELHOR } \\
\text { ATRIZ }\end{array}$ & & & & & $\begin{array}{l}\text { RHAISSA } \\
\text { BITTAR }\end{array}$ & \\
\hline $\begin{array}{l}\text { MELHOR } \\
\text { ESPETÁCULO }\end{array}$ & & & & & 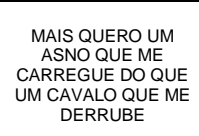 & \\
\hline $\begin{array}{l}2^{\circ} \text { MELHOR } \\
\text { ESPETÁCULO }\end{array}$ & & & $\begin{array}{l}\text { LENDAS - O } \\
\text { PENTAGONO } \\
\text { GREGO }\end{array}$ & & & \\
\hline
\end{tabular}




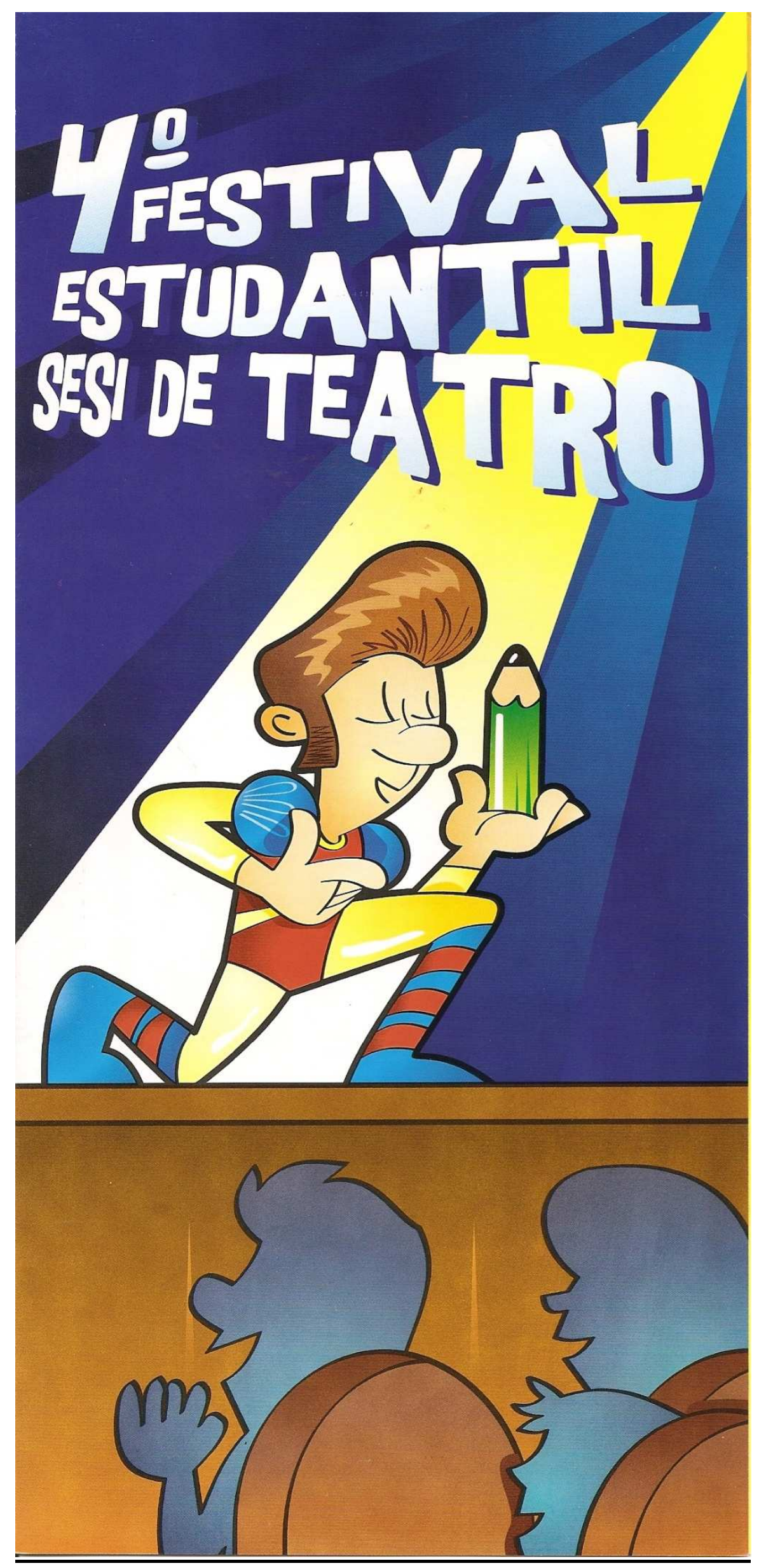


O que se discutiu no $4^{\circ}$ Festival Estudantil de Teatro foi 0 desenvolvimento do trabalho do teatro estudantil e a preocupação pela falta de valorização por meio governamental, o não incentivo. Observou-se, também, uma demonstração de desmotivação pelos próprios participantes. O motivo é que muitas escolas desprezam o festival estudantil e se recusam a participar.

Outro ponto observado foi, como fazer com que diretores e coordenadores de escolas se envolvam no trabalho para entender a importância do festival e as dificuldades que são enfrentadas durante 0 processo. Um ponto muito positivo foi um debate aberto só para os participantes do festival, no qual debateram os problemas e muitos encontraram caminhos para soluções. As oficinas, consideradas muito motivadoras, foram: Os Quatro elementos, ministrada por Ilo Krugli e Cirandas e Rodas, por Fátima Campidelli. Os espetáculos foram analisados por Pámela Duncan $^{15}$, Ingrid Dormien Koudela e Silnei Siqueira ${ }^{16}$.

O que dá para notar é que a cultura em si fica sempre por último plano e, principalmente, o teatro... Assusta-me um pouco, perceber que o teatro estudantil está morrendo e ele que é um grande incentivador da cultura, divulga textos, revela talentos e, por essa razão, precisa ser mais cultivado. Se não houver uma reunião dos grupos e esses grupos não assumirem esse papel, o festival tenderá a se extinguir. O festival não pode ser apenas uma semana, ele deve ser um resultado de um trabalho permanente. Precisamos nos fortalecer para que o Teatro estudantil exista independentemente de Sesi e outros órgãos. Percebo que dentro das escolas está havendo uma 136

${ }^{15}$ Diretora do Grupo de Teatro Físico a Peste, Ci8a Urbana de Teatro/ Nasceu em recife/PE. Diretora de teatro, arte-educadora, escritora, produtora e atriz. Parte de sua vida morou em diferentes paises da América. Estudou dança teatro e educação em Buenos Aires e São Paulo. É curadora e produtora de eventos importantes na cidade de São Paulo como "Art Futura", evento internacional realizado no Itaú Cultural. "30 anos do Colégio Pentágono", no estádio do Ibirapuera, "Vitória da Paz" no Espírito Santo. Drige Show e prepara cantores para sua melhor performance.

${ }^{16}$ Formado pela EAD Escola de Arte Dramática de São Paulo (1961), iniciou-se em teatro em 1953, quando cursava o último ano do $2^{\circ}$ grau no Mackenzie, compôs o Grupo de Teatro do Clube Pinhiros (GTP) (1954-1955) e o Teatro Paulista do Estudante (TPE) (1956 e 1958), quando ingressou na Escola de Arte Dramática de São Paulo (1958). Trabalhou como ator em mais de 20 peças, desde 1953. 
acomodação de esperar sempre e depender dessas entidades, devido a isso, nesse quarto festival sugeri a criação de uma comissão.

Desde a data do festival, foram mandadas vinte e três mil fichas de inscrições e apenas noventa inscrições voltaram, esperava-se pelo menos 10 de retorno. Por isso percebo, nesse momento, que o teatro estudantil está em nossas mãos, depende de nós assumirmos efetivamente a organização desse evento.

É necessário que se faça uma reflexão sobre as formas de manutenção do festival estudantil. Observou-se que o esforço tem que ser de cima para baixo, havendo uma intervenção junto à Secretaria de Cultura. O festival vem cumprindo o seu papel de fomentar a cultura entre os estudantes e vem exercendo importante papel na formação de público. No início desse ano, houve muitos candidatos interessados em uma vaga para cursar teatro, devido a isso, ressaltei que urgia unir forças para formar uma base com o intuito de colocar diretrizes para a realização do festival. É preciso que se crie uma comissão permanente que tenha propriedade para reformular o festival, elaborar oficinas e criar critérios para a atuação dos jurados. Lancei a inda a idéia de que o festival aconteça em outras unidades do Sesi.

Nesse quarto festival, a maior reflexão foi realmente na continuidade dele e a preocupação de novas diretrizes. 
QUEM CASA, QUER CASA, OU NÃO?

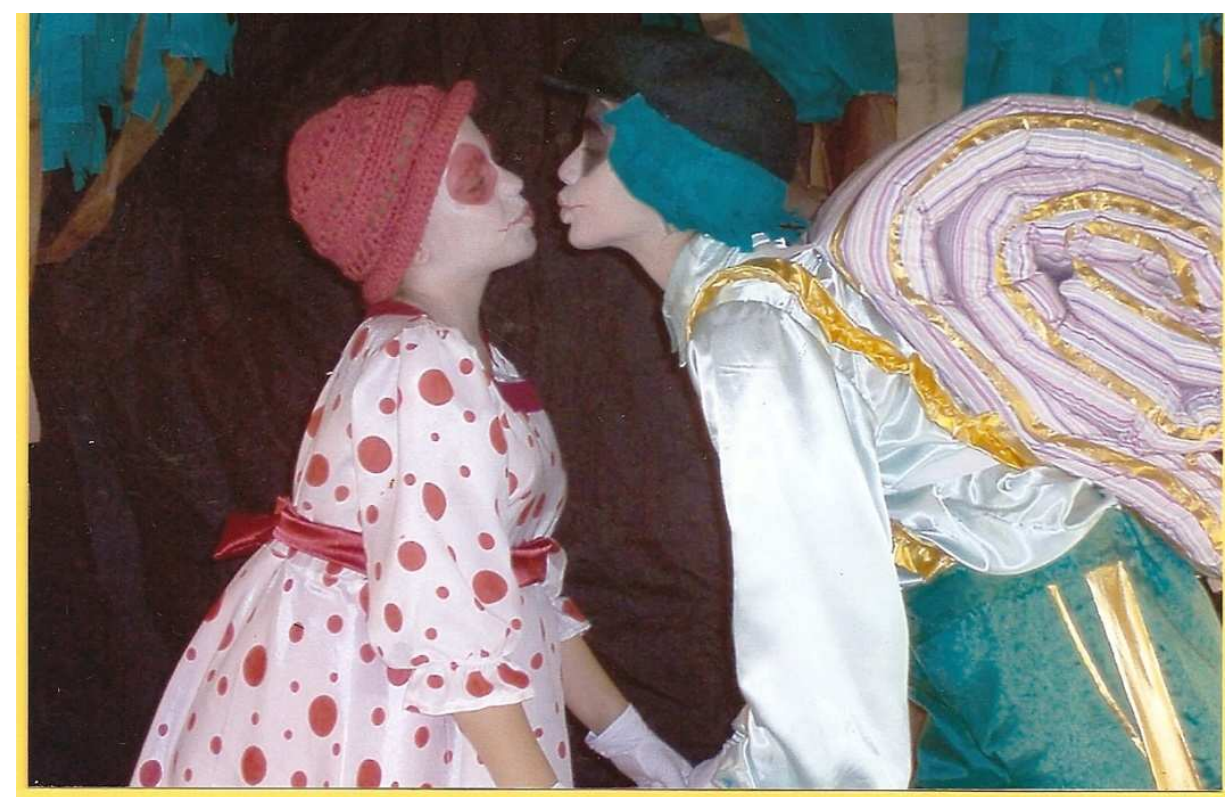

Autor: Tatiana Belinky

Grupo: Tia Thereza \& Cia

Escola: E. E. Dr. Gualberto Moreira

Cidade: Sorocaba

O grupo Tia Tereza e Companhia vem com sistematicamente em processo de transformação; alunos que estavam em cena passam a fazer parte da ficha técnica e novos integrantes vão dar vida aos personagens. Com o espetáculo Quem casa, quer casa ou não? de Tatiana Belinky, com a direção da professora artista Tânia Boy vem surpreendentemente com um teatro para criança cuidadosamente realizado. Destaques para alguns alunos atores que estréiam nesse espetáculo, o que fica muito presente também é a integração escola e comunidade. 


\section{RELEASE}

O espetáculo infantil, conta a história de Lelé, uma lesminha, que está à procura de um marido que seja bom partido. Então ela conhece Mujim, o caramujo, e a vida na floresta fica muito agitada. Todos os bichos que moram lá querem ajudar a lesminha a fazer um bom casamento. A peça é uma comédia musical com uma trilha sonora muito variada onde todos os bichos dançam e cantam.

\section{FICHA TÉCNICA E ARTÍSTICA:}

Direção e Adaptação: Tânia Boy.

Sonoplastia: Roselaine Boy e Rodrigo Almeida

Operador de Som: Rodrigo Almeida

Figurino: Maria Aparecida Ribeiro

Maquiagem: Marli Vera

Preparação Corporal: Gislene Sales

Coreografia: O grupo Iluminação: Tânia Boy e Diego Kenit

Operador de Luz: Diego Kenit

Contra-Regra: Marisa Campos, Laura Ribeiro, Giulia Ribeiro, Renan Simões

Nadine Marca (Lesma Lelé)

Ana Laura Furigo (Caramujo Mujim)

Ana Heloisa Fontes (Lesmo

Lesmundo)

Monique Novaes (Macaco Pong)

Míckaelly Mola Maçado (Ping)

\section{ELENCO}

Bianca Farias (D. Coelha)

Ana Clara Furigo (Coelhinha)

Érica Guizardi (D. Coruja)

Agatha Galdine (D. Joaninha)

Talita Albanez (D. Onça)

Jéssica Saez (D Borboleta) 


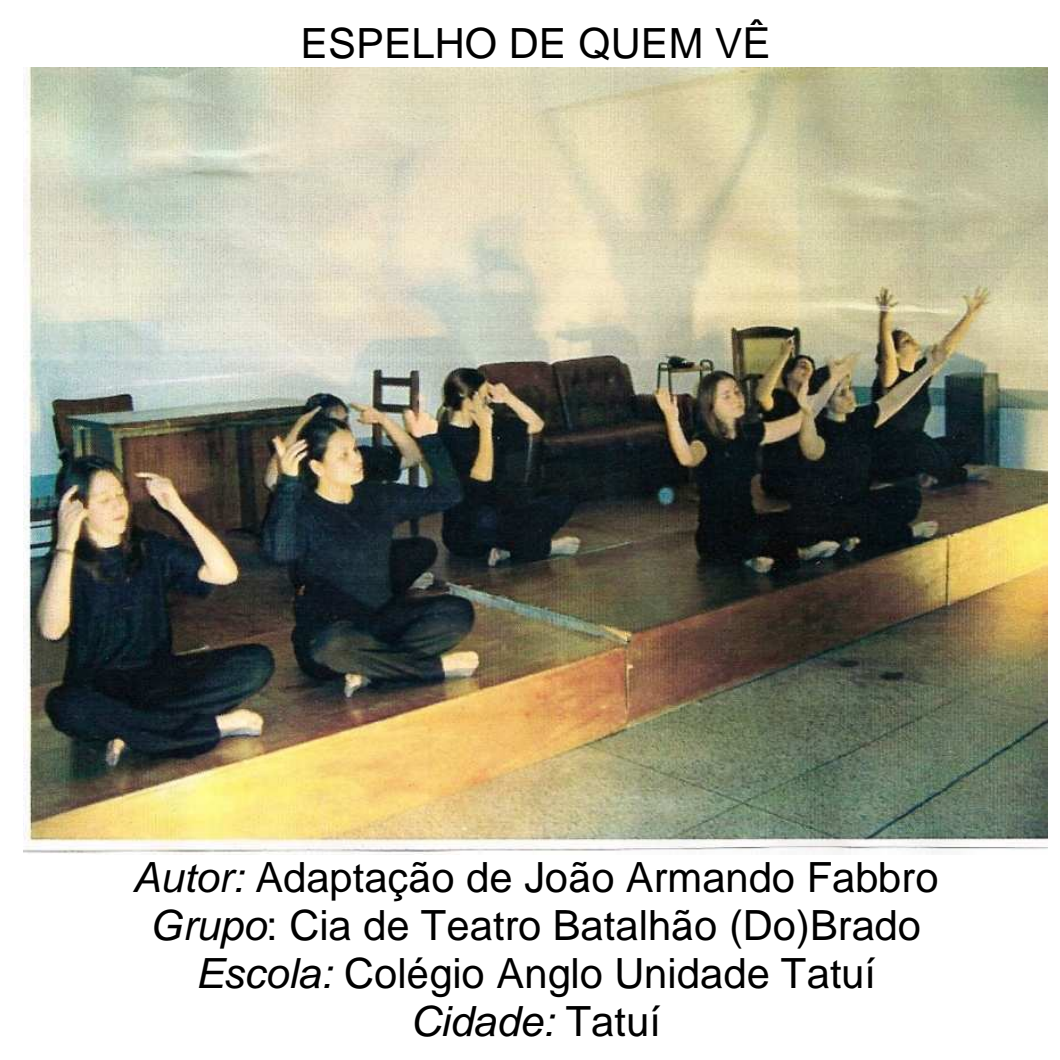

Adaptado e dirigido por João Armando Fabbro, a Cia de Teatro Batalhão (DO)Brado, da cidade de Tatuí é a primeira vez que participa desse festival. $O$ espetáculo teve momentos sofríveis e que em muitos momentos não agradaram ao público em geral. Durante o debate foi questionado o processo de trabalho e a maneira que foi criado, assim como a seleção das crônicas. João Armando Fabbro é proveniente do grupo Cia Pereirão de Teatro. 


\section{RELEASE}

Uma colagem de crônicas e contos de autores da nossa literatura selecionados para compor cenas que mostram algumas facetas do cotidiano, tendo em seu processo dialético o divertimento e a reflexão. Desencontros, malandragens, descobertas, a vida do homem dentro de casa e na sociedade são ingredientes para uma mistura saborosa de situações, que nos levam a um pensamento sobre nossos hábitos e ações dentro do universo em que vivemos o dia-a-dia. Assim, várias histórias trazem a vida na sociedade, preocupações, causos e situações, às vezes, hilárias. Uma pesquisa que visa à observação do pensamento sócio-cultural do ser humano, através do fazer teatral.

\section{FICHA TÉCNICA E ARTÍSTICA:}

Adaptação e Direção: João Armando Fabbro Sonoplastia: Alan Baio Bonel e Sérgio Roberto Andrade Guitarra: Sérgio Roberto Andrade Percussão: Alan Baio Bonel Cenário: João Armando Fabbro Figurino: Cia de Teatro (DO)Brado Iluminação: Thiago de Castro Leite

Bruna Carla Aguiar

Caroline Garcia Isabel Mercadante Elton Pinheiro Laura Baggio Nathália Fernandes Regiane Delarole Tânia Carnielli Assumpçâo
Operador de Luz: Elton Pinheiro e Thiago de Castro Leite Fotos: Felipe Costa Mercadante Cenótecnica: Edsel Rodrigues Teles, André Luis Camargo, Marco Antônio, Adriana Innocencio, José Benedito Meneses, Bruno Giraldhí, Rafael Ghiraldi, Danilo Reali e Fernando Henrique Casalunga.

\section{ELENCO}




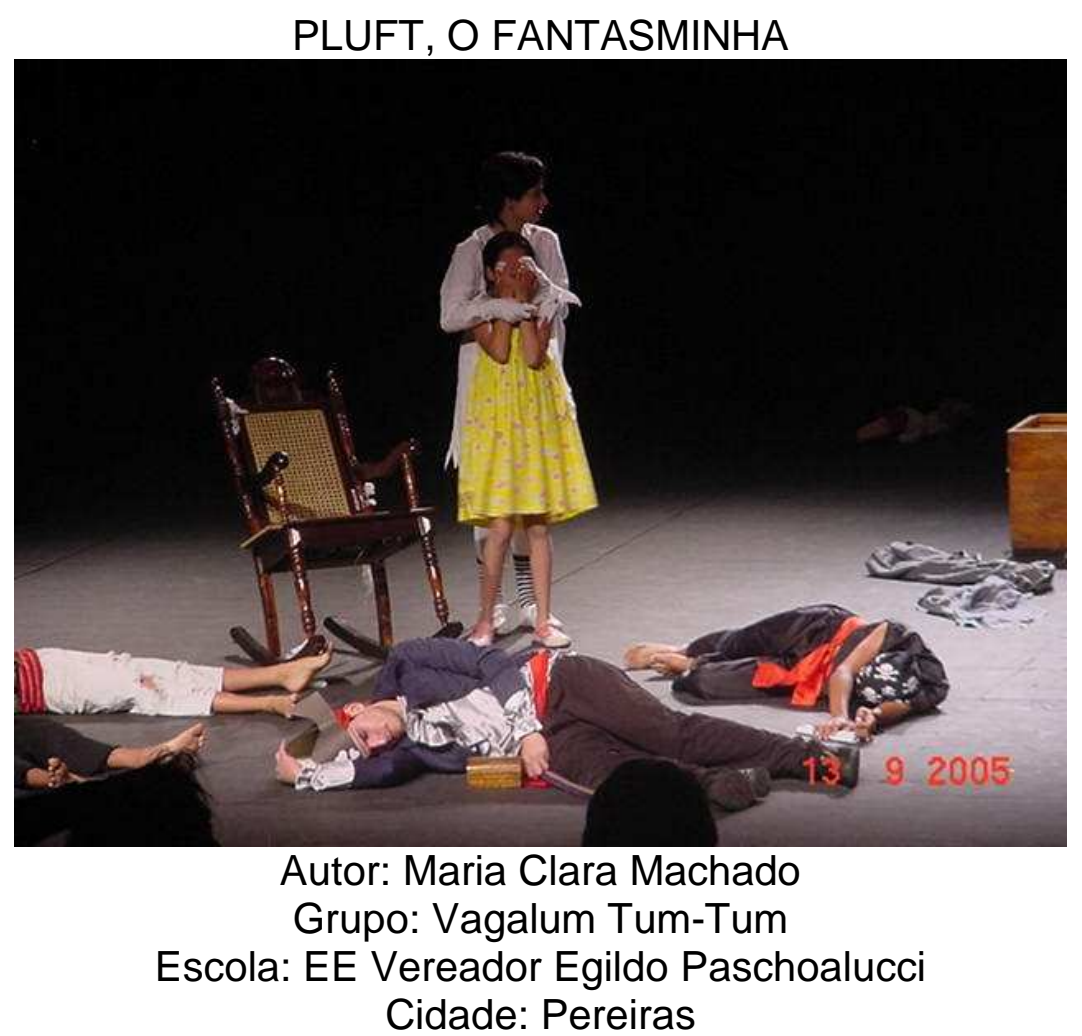

Da escola Vereador Egildo Paschoalucci, da cidade de Pereiras, é a primeira vez que também participa desse festival embora o texto de Maria Claro Machado tenha um suporte ideal para montagem, o espetáculo teve problemas de ordem técnica. O espetáculo nasceu de uma oficina de teatro que aconteceu naquela cidade. Durante o debate ficou nitidamente perceptível que a escola e a prefeitura da cidade dão total apoio ao grupo, o espetáculo agradou as crianças principalmente o conjunto dos três piratas. 


\section{RELEASE}

Pluft, sua mãe e um velho tio moram em uma casa abandonada, onde se supõe morou o velho Capitão Bonança. O fantasminha tem medo de gente e sua situação se complica quando o marinheiro Perna de Pau resolve raptar a neta do Capitão Bonança, para descobrir onde foi escondido o tesouro do velho Capitão. Ele decide levar a menina exatamente para a casa que foi do Capitão e onde mora Pluft. A partir daí a história se desenrola com o fantasminha manifestando seus medos e também a sua simpatia pela pobre menina raptada, a quem resolve ajudar. A peça é cheia de surpresas e sustos que entusiasmam a criançada que, no fim do espetáculo, está completamente apaixonada pelo simpático personagem.

Direção: André Luiz Camargo

FICHA TÉCNICA E ARTÍSTICA:

Assistente de Direção: Renato Fontanelli

Figurino: Renato Fontanelli

Operador de Luz: Anderson Soares

Operador de Som: André Luiz de Camargo

Contra-Regra: Faustino Assad.

\section{ELENCO}

Verônica Miranda de Morais: Pluft, o Lincon Willian Velasco: João fantasma

Talita Gazolla: Mãe Fantasma

Adriana Felice de Camargo: Xisto 1

Renato Fontanelli: Perna de Pau, marinheiro pirata

Luiz Otávio de Freitas Dezzotti: Xisto 2 Gabriela Corrêa dos Santos: Xisto 3 Renata Batista Vieira: Xisto 4 Joselma Pereira da Silva: Xisto 5

Caroline Justino Maciel: Maribel, menina Érica Jesus Vieira: Xisto 6

Cleiton Cristiano de Oliveira: Gerúndio, Michele Taina Andrade Bento: Xisto 7 tio do Pluft Anieli Cristina Fontanelli: Xisto 8 Stephan Richard de Oliveira: Sebastião Janaína Érica da Silva: Xisto 9 Inglitis Karen de Oliveira: Julião 


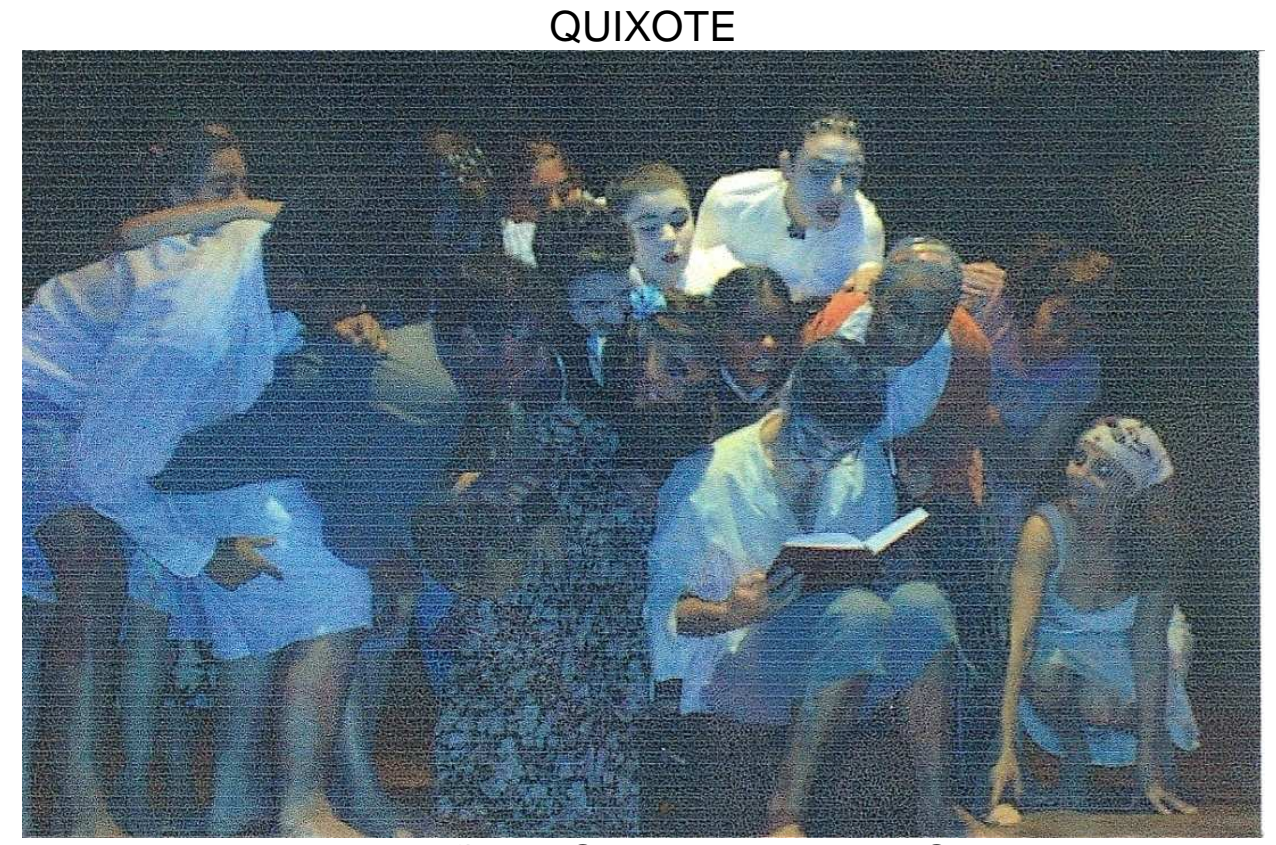

$$
\begin{gathered}
\text { Autor: Adaptação da Obra de Miguel de Cervantes } \\
\text { Grupo: Grupo Teatral Colégio Progresso Centro } \\
\text { Escola: Colégio Progresso Centro } \\
\text { Cidade: Guarulhos }
\end{gathered}
$$

Da cidade de Guarulhos, uma adaptação da obra de Miguel Cervantes com o grupo teatral Miguel Progresso Centro, em que os professores artistas Rogério Brito, Débora Scaldelai e Edson Padilha desenvolvem trabalho extracurricular de teatro com o grupo e é a primeira vez que participam desse festival. Um espetáculo de difícil realização que não foi muito bem aceito pelo público e, durante o debate, foi muito contestado pelos jurados principalmente pela estrutura dramática que se perdeu a partir da adaptação. 


\section{RELEASE}

$\mathrm{Na}$ cidade da Mancha vivia um fidalgo que pelo gosto das leituras de cavalaria gastou toda a sua fortuna em livros e na companhia deste passou a viver trancado em sua biblioteca. Enfim, o espetáculo é um passeio na imaginação das pessoas e é um convite para uma viagem fantástica em busca de nós mesmos.

\section{FICHA TÉCNICA E ARTÍSTICA}

Sonoplastia e Operador de Som: Juliane Espanta

Operador de Luz: Débora Scaldelai

Direção: Rogério Brito/Débora Scaldelai e Edson Padilha

Figurino e Adereços: O Grupo

Cenário: O Grupo

\section{ELENCO}

Edson Padilha: Dom Quixote Laércio Franciolli: Sancho Pança

Eduarda Barroso: Ama Jéssica Torres: Sobrinha

Daiane Sobrera: Tereza Pança Leandro Saundag: Santo Inquisidor Erick Garcia: Coroinha Marcelo Ferreira: Cavaleiro do bosque; curu:
Feiipe Araújo

Tabata Faquineiii Luciene Faquinelli Vanessa Aparecida Letícia Marques Mariana dos Santos Barbara Faquinelli Gabrielle Ragnain 


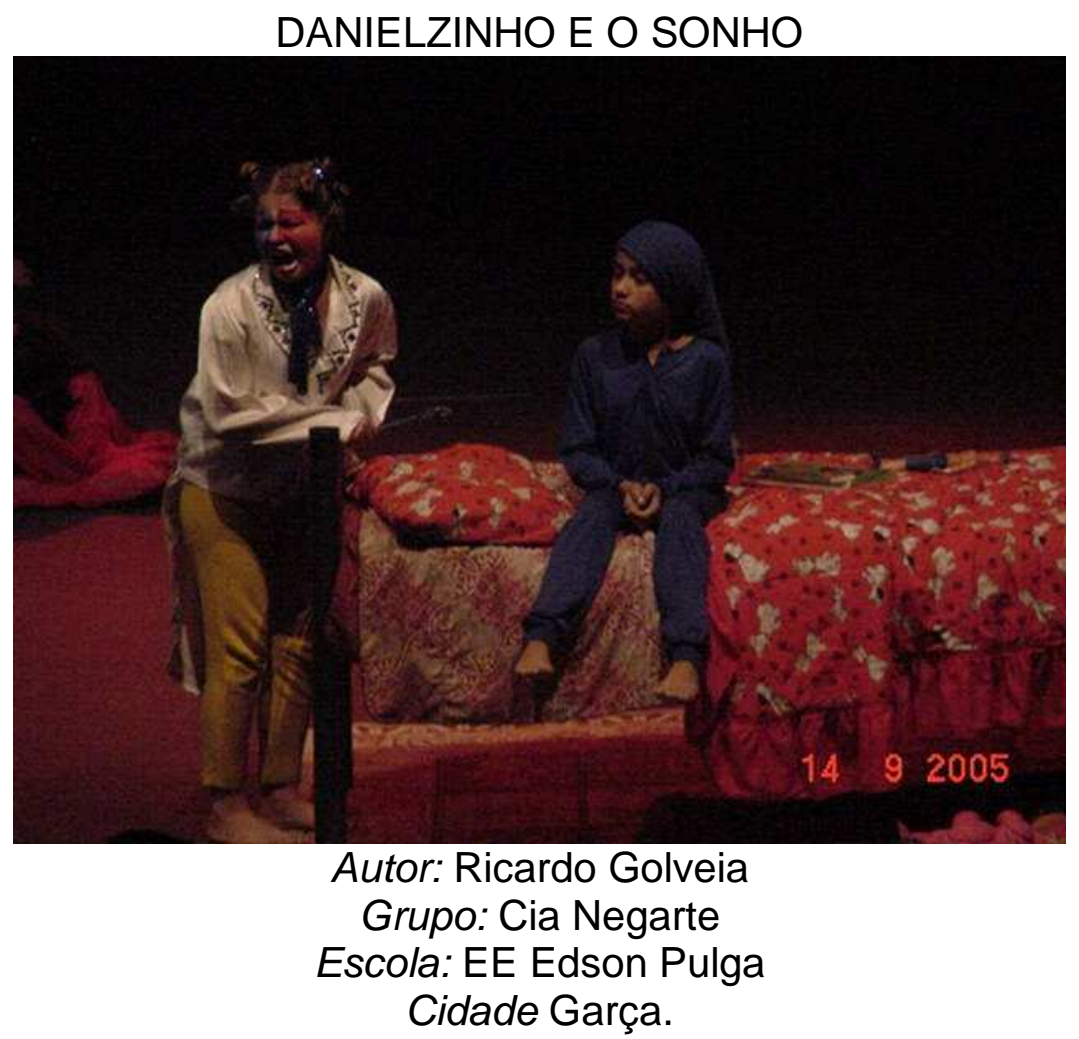

Da cidade de Garça, o grupo Cia Negarte, participantes pela primeira vez nesse festival, apresentou um espetáculo simples mais que conquistou as crianças, embora se perceba a falta de jogos dramáticos que não foram trabalhados com os atores, mas mesmo assim o espetáculo aconteceu. Durante o debate, foi exposto que era a primeira montagem do grupo e que fizeram o trabalho a partir de tomada de conhecimento da existência do festival e que apenas iriam fazer algumas apresentações na escola. Este grupo nunca mais retornou ao festival, embora a comissão julgadora tenha indicado muitos caminhos para que eles buscassem teorias e desenvolvessem jogos dramáticos para evolução do trabalho teatral. 


\section{RELEASE}

Quando o sonho de Danielzinho foge, aparece um "carteiro" que se diz fiscal do sono. E esse fiscal leva Danielzinho para o mundo do $A L I$,para encontrar o seu sono, mas nesse mundo encontram vários obstáculos, como por exemplo, a Dona Dor de Cabeça".

\section{FICHA TÉCNICA E ARTÍSTICA}

Direção: Duliana Perez lluminação: Renato Lopes

Sonoplastia: Alex Alves e Jéferson Guimarães

Cenografia: Luiz Cabral e Edílson Bernardes

Figurino: Elizangela Geronimo

Conta-Regras: Guilherme Matsumoto, Fernanda Lima e Ariane Dias.

Amanda Meira Dias: Danielzinho

\section{ELENCO:}

Geovana Alves: Carteiro

Tatiana Buzim: Sono

Joseane Macedo: Zingondengo

Tiago Macedo: Pai

Daniela Maria: Dona Dor de Cabeça

Aline Dias: Sono

Rosana Fraione: Sono 
A CARA DO BRASIL

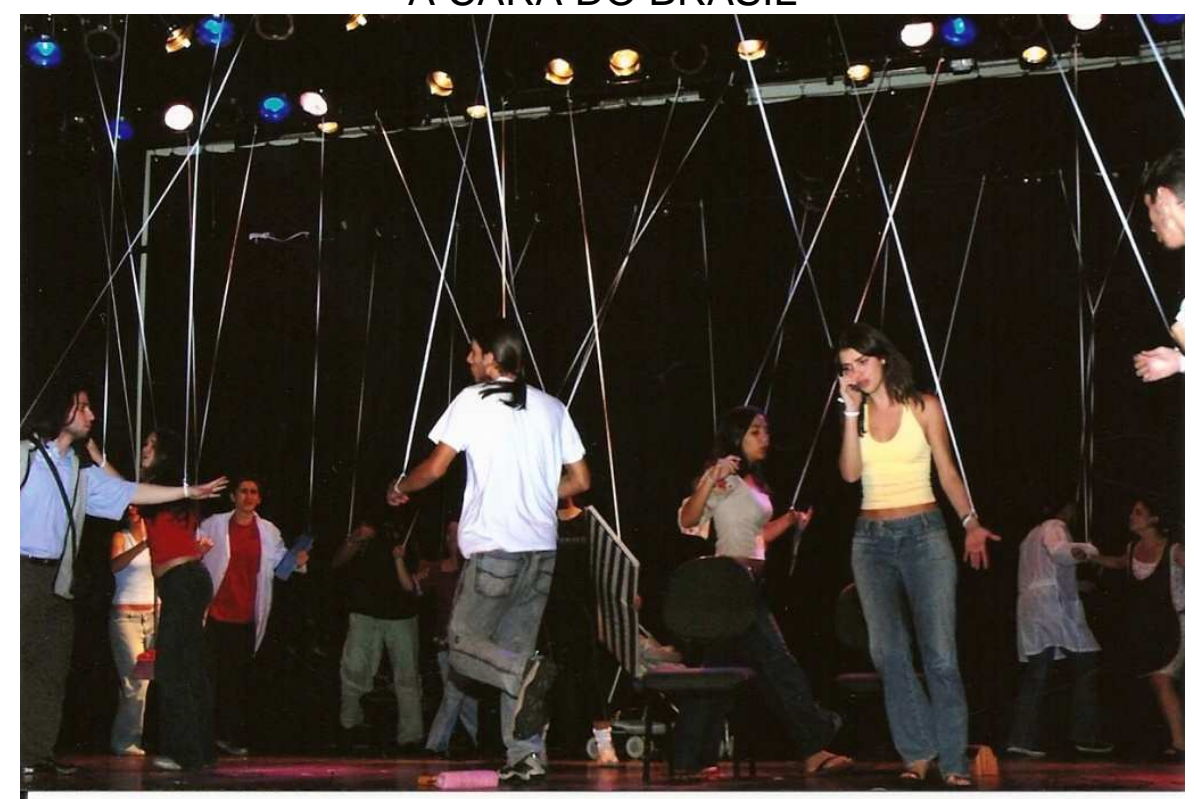

Autor: Adaptação do grupo

Grupo: Grupo de Veteranos do Colégio Jardim São Paulo

Escola: Jardim São Paulo

Cidade: São Paulo.

Do grupo de veteranos do Colégio Jardim São Paulo, com direção geral e musical de Abigail Wímer, o espetáculo trouxe uma grande pesquisa sobre o teatro brasileiro, com muitas músicas. Agradou muito o público, mostrava um cenário muito colorido. Seu repertório musical fez o público cantar junto com o espetáculo. Durante o debate, algumas questões foram levantadas e o que ficou muito claro foi que a pesquisa não tinha sido realizada de maneira correta, pois haviam equívocos uma vez que as músicas eram usadas como parte do texto. 


\section{RELEASE}

Como primeiro projeto dos "veteranos" do grupo Colégio Jardim São Paulo, o texto foi escolhido pelos próprios integrantes. Uma grande pesquisa sobre o Teatro Brasileiro e MPB resultando numa colcha de retalhos com cenas e músicas favoritas do grupo. É um espetáculo em esquetes de cenas livremente adaptadas de grandes peças, como Campeões do Mundo, Quarto de Empregada, O Auto da Compadecida, Roda Cor de Roda e Dois Perdidos Numa Noite Suja todas adaptadas pelos próprios atores. A idéia principal era montar um espetáculo bem diversificado tanto nos temas abordados, como nos gêneros apresentados. Assim, poderíamos agradar ao público que prefere a comédia, ou o drama, cenas do cotidiano, episódios históricos etc... Num único espetáculo, além de testar a versatilidade dos atores.

\section{FICHA TÉCNICA E ARTÍSTICA}

Direção Geral e Musical: Abigail Wimer

Direção de Atores: Silen de Castro

Luz e Som: Silen de Castro

Teclado: Abigail Wimer

Baixo: Daniel
Bateria: Caio Milan

Violão: Carol Melo

Trompete: Roger Brito

Saxofone e cavaquinho: Mariana

Castelone.

\section{ELENCO}

Ana Montero: Sueli e Cantora da procissão

Gustavo Sanna: Paco e Passageiro do Metro Elena Castro: Cantora da Abertura e Rosa Izadora Teodoro: Tânia

Leandro Machado: João Grilo e Passageiro do Metro Marilia Morreno: Até Quando e Intelectual

Bruna Luiza: Amélia e Cantora da procissão Bruno Viera: Tonho

Carlos Sanmartim: Zé , Oração do Nordestino, Blefe e

Intelectual

Daniela de Castro: Zefa

Danille Machado: Compadecida, Pedinte e Intelectual

Mariana Menberg: Mariquinha, Passageira do Metro e Intelectual

Mario Ispaziani: Português, Muler e Jesus

Paulo do Nascimento: Brazuca, Padre e Intelectual

Raquel Morreno: Santa, Zé Batalha e Homem Branco

Flavio do Nascimento: Rapper.

Gian Pacolla: Diabo e Intelectual 


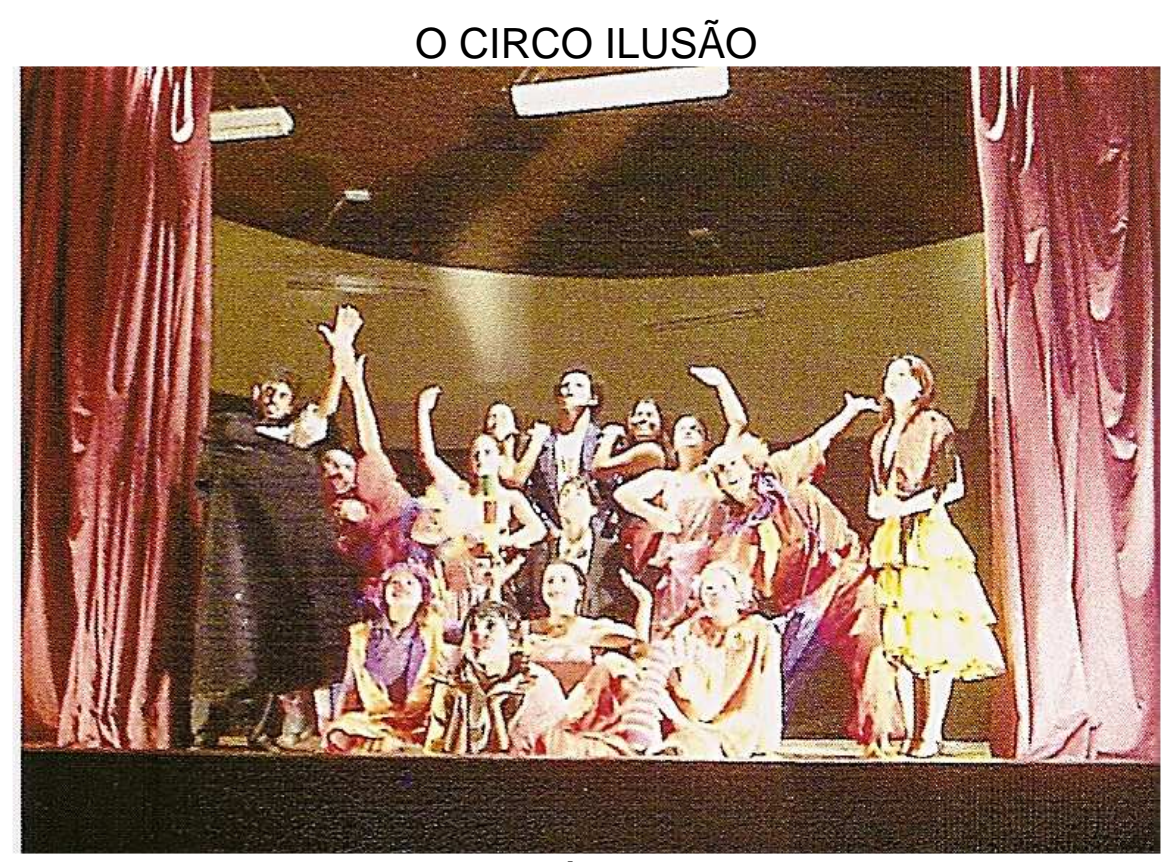

Autor: Fábio Jurera

Grupo: Tapanaraca Mutatis Mutantis

Escola: Instituto Peixoto Gomide

Cidade: Itapetininga

Do grupo Tapanaraca, da cidade de Itapetininga, do autor e diretor do espetáculo professor artista Fábio Jurera. O espetáculo tem grandes dificuldades de realização, não consegue uma comunicação com o público infantil e em muitos momentos nos quais se queria passar uma historia lúdica sobre o circo se confunde, não conseguindo fazer com que o espectador se aproprie da história. Durante o debate, o grupo ficou atento à colocação dos jurados que foram pertinentes em muitos assuntos de relevância para o grupo e o espetáculo. É a primeira vez que esse grupo participa de um festival de teatro, o que nos chamou a atenção foi que, após um longo debate, o diretor agradece e aparentemente demonstrou ter sido tocado por tudo que foi dito e que vai ser levado em consideração e colocado em prática. 


\section{RELEASE}

A peça traz um caráter extremamente circense e conta a história da menina Júlia que foge de casa para realizar seu sonho de ser palhaça de circo. Arrigo, o palhaço e sua esposa Ana, a bailarina, estão de partida do circo após 40 anos de picadeiro. Juntos começam a relembrar os velhos tempos do Circo llusão e os momentos mais inesquecíveis nesta longa jornada.

\section{FICHA TÉCNICA E ARTÍSTICA}

Iluminação: Lucy Villar

Sonoplastia: Sandro Rogério

Pesquisa Musical: Fábio Jurera

Figurino: Lucy Villar

Maquiagem: Haya Medeiros
Fotografia: Athur Ferrarezi

Adaptação do texto: Fábio Jurera

Coreografia: Lucy Villar

Direção do elenco: Lucy Villar

Direção Geral: Fábio Jurera.

\section{ELENCO}

Jéssica Oliveira: Júlia Deivid Rodrigues: Arrigo Yuri Abuázar: Arrigo Jovem / Gogo Nathalie Morelli: Ana Daniele Ayres: Ana Jovem Jhonny Medeiros: Joãozinho / Boy Ana Dias: Maria / Crystal Nathalia Melo: Luna
Anderson Thiago: Nestor / Joãozinho

Ana Cristina Quirino: Reco - Reco Kamila Kurnick: Bolão / Star Jéssica Mayara: Azeitona Suellem Felix: Bolo / Tarraxa W.W Gomes: Sr. Estranho Bruna Jolie: Madame Zoraide 


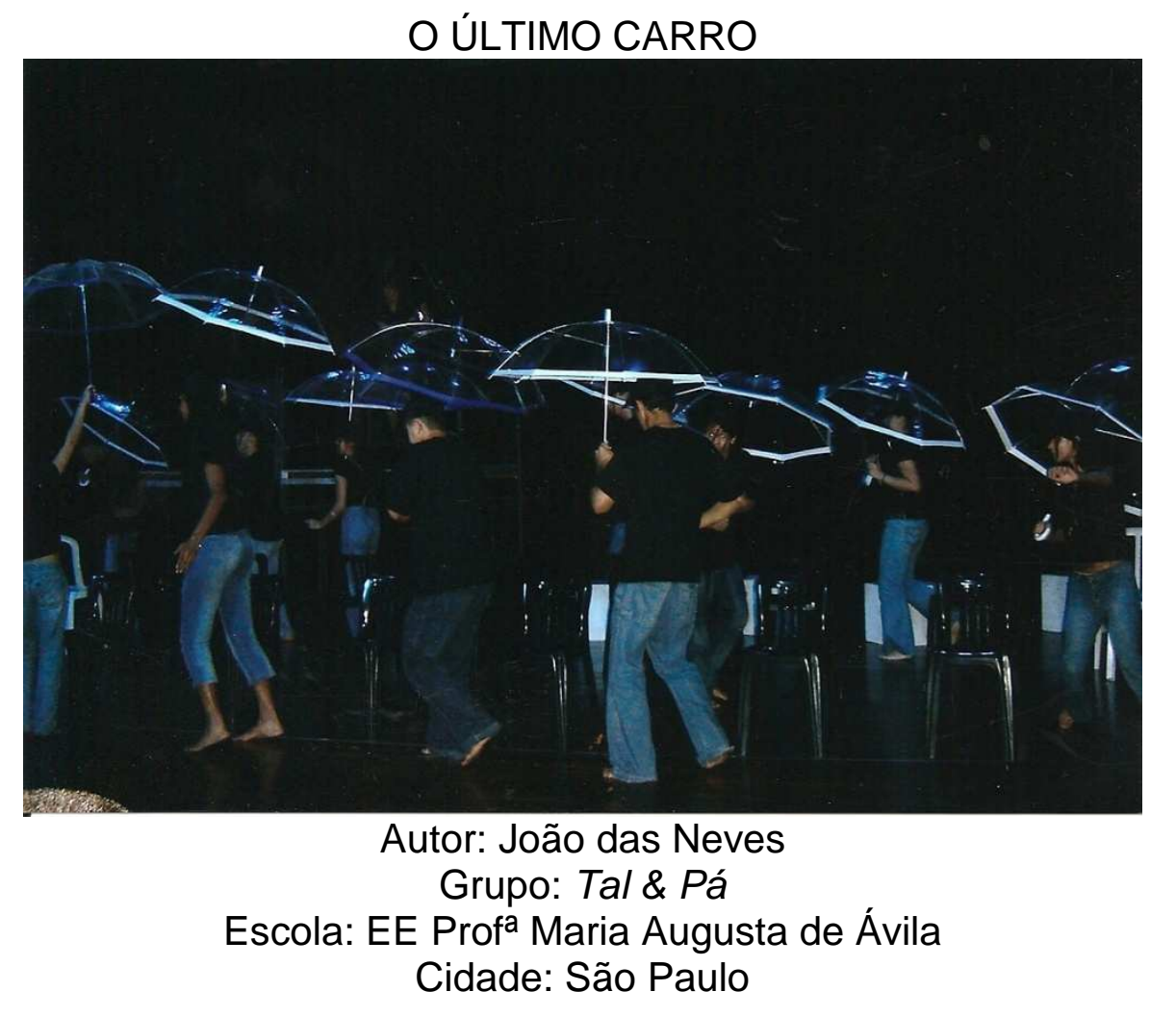

O último carro do grupo Tal\&Pá dirigido pela professora artista Valéria de Oliveira traz para o palco um espetáculo assertivo, emocionante e com soluções que transportavam a platéia para o palco. O espetáculo, que é bem próximo da realidade dos alunos, mais uma vez em sua participação, mostra a força da comunidade em seus trabalhos. Durante o debate o espetáculo foi muito elogiado e um dos destaques foi pela belíssima direção. 
RELEASE

O Último Carro, texto de João Das Neves, traz para o espectador uma preocupação temática básica: a discussão de problemas concretos do povo brasileiro. Aparentemente, trata-se de uma simples viagem de trem no subúrbio, onde mendigos e operários, diversos personagens comuns a esse cotidiano, enfocam suas dramas particulares durante a viagem e suas paradas. Os vários "pequenos dramas" perdem a sua autonomia e ganham organicidade dramática ao serem confrontados com a louca corrida do trem que, subitamente, parece já não mais obedecer a nenhum comando racional, obrigando a todos uma definição radical sobre seus destinos.

\section{FICHA TÉCNICA E ARTÍSTICA}

Produção e direção: Valéria de Oliveira Sonoplastia Musical: Soraya de Oliveira Coordenação Técnica e Iluminação: Carina Viana Preparação Corporal: Gisele Xavier Coreografia: Ariovaldo Junior Cenografia: Grupo Tal \& Pá Figurinos: Grupo Tal \& Pá

Robson Salvador: Zé Leiliane do Vale: Zafa Letícia Job: Guarda da Estação

Rafael Fabrício : Jorge (falador)

André Abbenante: Deolindo Suellen Santana: Mira Alairton Lopes: Pedro Wagner de Freitas: Neco Carol Silva: Mãe Ariovaldo Junior: Beto
Maquiagem: Grupo Tal \& Pá Operador de som: Soraya Oliveira Operador de Luz: Carina Viana Contra-regras : Júlio Cesar / Bianca Diniz / Aline Diniz Auxiliares: Adriano Lisboa / helena de Oliveira / Eliana Mandes / Tomiko Oishi

\section{ELENCO}

Lúcia Leão Nunes: Marinha Cristiana Fabrício: Regina (prostituta)

Fábio Junior: Antônio Herbert Ameida: Cicatris Aline Oliveira: Cabelo Jones Marinho: Idoso Camila Navarro: Vendedora de chiclete

Caio Nunes: Vendedor de cocada

Gisele Xavier D. Floriana (Vó)
Valkyria Cardoso: Judite Douglas Azevedo: Sebastião (pai)

Letícia Santos: D.Luiza (mãe) Márcia Venâncio: Silvia Anderson Miranda: Bilheteiro Renatha Fernandes: Guarda da plataforma Eduardo Carvalho: Beato Felipe Lorenzini: passageiro Nataly Santos: passageira 


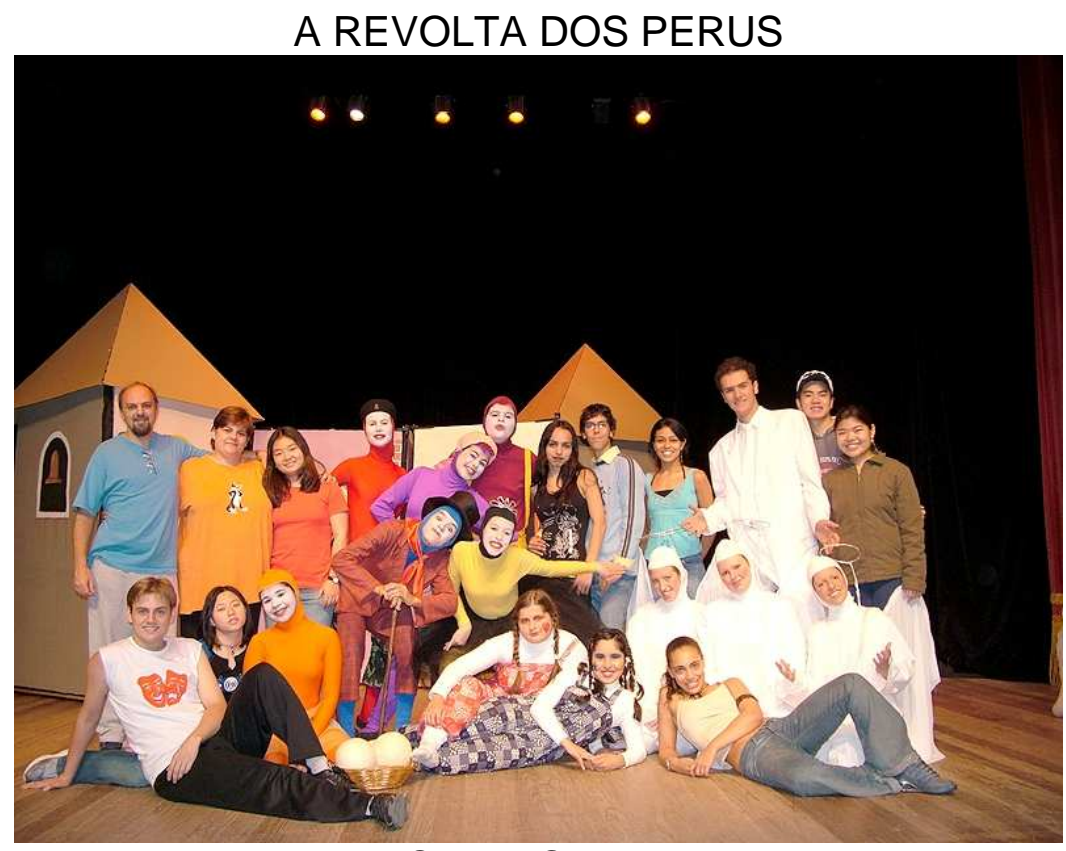

Autor: Carlos Queiroz Teles

Grupo: Grupo Teen de Teatro Santo Agostinho

Escola: Colégio Santo Agostinho

Cidade: São Paulo

Em sua quarta participação nesse festival, o grupo teen do teatro Santo Agostinho, dirigido pela professora artista Pámela Paz, surpreende com 0 espetáculo a Revolta dos Perus. Um espetáculo despretensioso, mas com uma energia que contagiava todas as crianças presentes.

O que se percebe é que cada vez mais o ritmo de trabalho e conceituação que grupos como este que trafegam várias vezes por esse festival vão tomando novas envergaduras de trabalho. Durante o debate, os jurados também se colocaram surpresos com o resultado do que tinham assistido, pois o trabalho de grupo era muito preciso e os jogos dramáticos faziam parte do processo de trabalho. 


\section{RELEASE}

Numa tarde de dezembro, quando o Natal já está por chegar, ouve-se a cantoria de Deus e dos Anjos para organizar mais uma festa abençoada. Porém ao ouvir as músicas, no terreiro, os Perus se revoltam já que a cada evento natalino quem vai para mesa são os Perus. Decidem então pedir ajuda para conseguir mudar essa história e assim vão para a cidade falar com o Bispo, já que Le é representante de Deus na terra. A história prossegue até conseguirem um encontro com Deus e este thes concede uma bênção especial. É com muita brincadeira e alegria que o Grupo Teen de Teatro Santo Agostinho vem com mais esta história musical, em que se percebe que nem tudo sai como a gente quer, mas é bom do mesmo jeito.

\section{FICHA TÉCNICA E ARTÍSTICA}

Direção Geral: Pamela Paz Cenário: O Grupo

Assistente de Direção: Camila Yumi e Operador de som: Yuri Saito Henrique Faria lluminação: Marcos Melim

Coreografias: Janaina Castro e Inara Santos Contra- Regras: Cintia Suzuki e Tais Trilha Sonora: Gilson Faria Magalhães

Nayara Araújo: Perualda Raul Sanches: Perulino Raissa Bittar: Perueta Beto Lin Do: Perulito Brenno Fonseca: Peruvô Larissa Gude: Peruêpa Natalia Mito: Peruá

\section{ELENCO}

Pablita Araujo: Coringuinha Daniella Restani: Coringão Rafael Junqueira: Deus Ana Fonseca: Anjo Gabriel Clara Nascimento: Perumãe Gabriela Malandrino: Anjo Ariel Camila Bignard: Anjo Josiel 


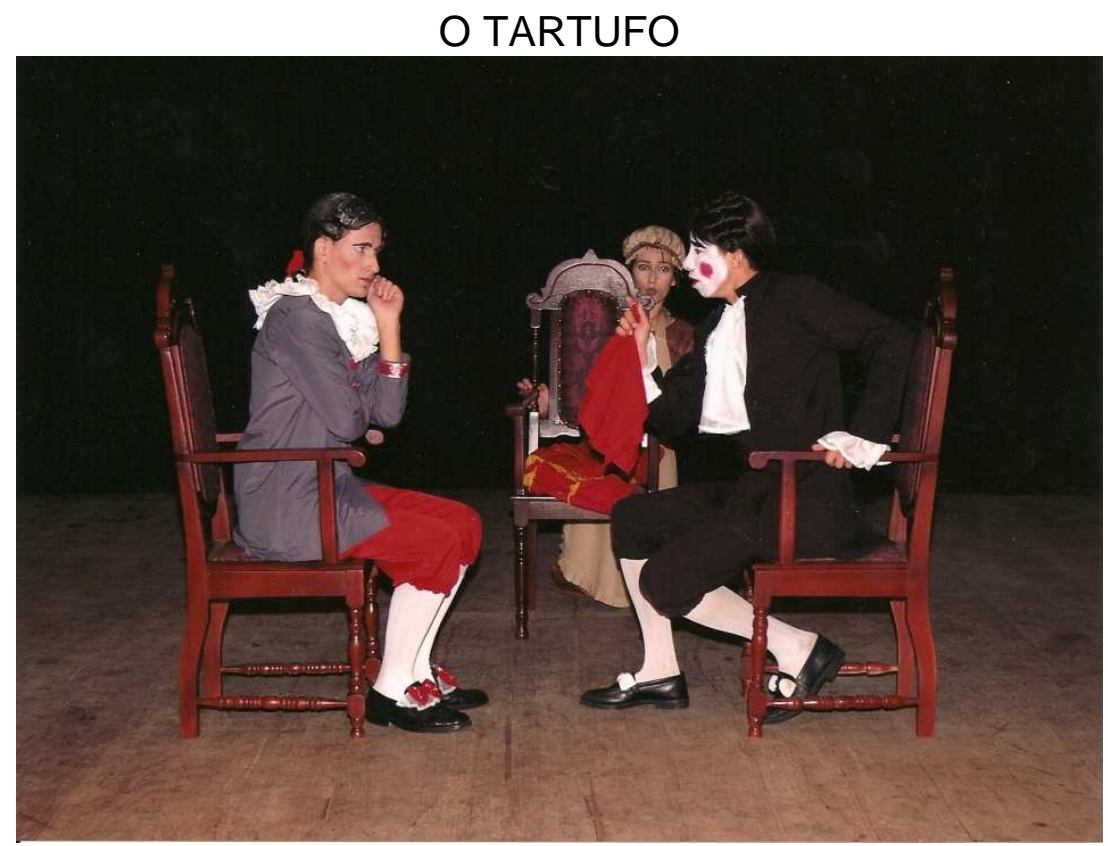

Autor: Molière, adaptado pelo Grupo

Grupo: Cia de Teatro UTA

Escola: EE Dr. Afonso Vergueiro

Cidade: Salto de Pirapora

O grupo participa pela segunda vez desse festival agora com a direção da professora artista Jane Kastorsky. Com o grupo recém-formado de alunos da escola Doutor Afonso Vergueiro, o espetáculo foi bem realizado, mas com texto difícil e por essa razão, a apresentação deixou a desejar e com muitos pontos que não agradaram ao público. O espetáculo chama a atenção pelo belo figurino que se sobressai à montagem. Durante o debate, o espetáculo foi muito criticado pela comissão julgadora e questionado sobre o processo de trabalho, embora a professora artista tenha se colocado nos questionamentos, a comissão foi relutante em falar da má realização do espetáculo.

\section{RELEASE}

Tartufo é um beato fanático que se hospeda na casa de um rico burguês- o ingênuo e religioso senhor Orgon. Inicialmente, humilde, Tartufo vai aos poucos dominando seu anfitrião por meio da farsa de um "espírito puro, devotado a Deus." 
Direção Geral: Jane Kastorsky Maquiagem e Cabelo: Karen Costa / Marcelo Bernini / Rôde Barrabella Sonoplastia e Operador de Som: Ivan Kastorsky

lluminação e Operador de Luz: Vinicius Rostelato
Figurino: Jane Kastorsky e Angélica Leme Confecção do Figurino: Áurea Aparecida dos Santos Cenografia: Dorival de Souza Fotografia: A. Tozze

Filmagem: Felipe Noris.

\section{ELENCO}

João Paulo do Anjos: Tartufo- beato fanático Jackson Emilio: Orgon- rico burguês e religioso Lays Cardinari: Elmire esposa dedicada de Orgon Angélica Leme: Sra. Pernelle- beata, mãe de Orgon Denise Vieira: Damis-adolescente, impetuoso, filho de Orgon Rafaela Ayres: Mariane- filha obediente de Orgon Denis Manzato: Valère- jovem, apaixonado por Mariane Paula Fonseca: Cléante-culto e racional, cunhado de Orgon Gisele Berenguel: Dorine- impertinente, dama "desligada", da Sra. Pernelle Zeca Campos: Laurent- criado de Tartufo / Domingos oficial, representante do Rei 
PREMIAÇÃO CATEGORIA INFANTIL

\begin{tabular}{|c|c|c|c|c|c|}
\hline & $\begin{array}{c}\text { QUEM CASA, } \\
\text { QUER CASA, OU } \\
\text { NÃO? }\end{array}$ & $\begin{array}{c}\text { PLUFT, O } \\
\text { FANTASMINHA }\end{array}$ & $\begin{array}{c}\text { DANIELZINHO E } \\
\text { O SONO }\end{array}$ & $\begin{array}{l}\text { O CIRCO } \\
\text { ILUSÃOO }\end{array}$ & $\begin{array}{l}\text { A REVOLTA } \\
\text { DOS PERUS }\end{array}$ \\
\hline $\begin{array}{l}\text { ATOR } \\
\text { REVELAÇÃo }\end{array}$ & & & & $\begin{array}{l}\text { ANDERSON } \\
\text { THIAGO }\end{array}$ & \\
\hline $\begin{array}{l}\text { ATRIZ } \\
\text { REVELAÇÃO }\end{array}$ & $\begin{array}{l}\text { MICKAELLY } \\
\text { MOTA }\end{array}$ & & & & \\
\hline $\begin{array}{l}\text { COADJUVANTE } \\
\text { MASCULINO }\end{array}$ & & & & $\begin{array}{l}\text { JHONNY } \\
\text { MENDES }\end{array}$ & \\
\hline $\begin{array}{l}\text { COADJUVANTE } \\
\text { FEMININO }\end{array}$ & & & $\begin{array}{l}\text { GEOVANA } \\
\text { ALVES }\end{array}$ & & \\
\hline CENOGRAFIA & & & & & \\
\hline ILUMINAÇÃO & & & & LUCY VILAR & \\
\hline FIGURINO & & & & LUCY VILAR & \\
\hline SONOPLASTIA & & & & & GILSON FARIA \\
\hline DIREÇÃo & & & & & PÁMELA PAZ \\
\hline MELHOR ATOR & & & & & RAUL SANCHES \\
\hline MELHOR ATRIZ & & $\begin{array}{l}\text { TATIANA } \\
\text { GAZOLLA }\end{array}$ & & & \\
\hline $\begin{array}{l}\text { MELHOR } \\
\text { COMUNICAÇÃO }\end{array}$ & & $\begin{array}{c}\text { PLUFT, } \\
\text { FANTASMINHA }\end{array}$ & & & \\
\hline $\begin{array}{l}\text { MELHOR } \\
\text { ESPETÁCULO JURI } \\
\text { POPULAR }\end{array}$ & & & $\begin{array}{c}\text { DANIELZINHO E } \\
\text { O SONO }\end{array}$ & & \\
\hline $\begin{array}{l}\text { MELHOR } \\
\text { ESPETÁCULO }\end{array}$ & & & & & $\begin{array}{c}\text { A REVOLTA DOS } \\
\text { PERUS }\end{array}$ \\
\hline $\begin{array}{l}\text { 20 MELHOR } \\
\text { ESPETÁCULO }\end{array}$ & $\begin{array}{c}\text { QUEM CASA, } \\
\text { QUER CASA, OU } \\
\text { NÂO? }\end{array}$ & & & & \\
\hline
\end{tabular}


PREMIAÇÃO CATEGORIA ADULTO

\begin{tabular}{|c|c|c|c|c|c|}
\hline & $\begin{array}{l}\text { ESPELHO DE } \\
\text { QUEM VÊ }\end{array}$ & QUIXOTE & $\begin{array}{l}\text { A CARA DO } \\
\text { BRASIL }\end{array}$ & $\begin{array}{l}\text { O ULTIMO } \\
\text { CARRO }\end{array}$ & O TARTUFO \\
\hline $\begin{array}{l}\text { ATOR } \\
\text { REVELAÇÃo }\end{array}$ & & & & & $\begin{array}{c}\text { VINICIUS } \\
\text { ROSTELATO }\end{array}$ \\
\hline $\begin{array}{l}\text { ATRIZ } \\
\text { REVELAÇÃo }\end{array}$ & & & & & GÉRICA SANTOS \\
\hline $\begin{array}{l}\text { COADJUVANTE } \\
\text { MASCULINO }\end{array}$ & & $\begin{array}{l}\text { LAERCIO } \\
\text { FRANCIOLLI }\end{array}$ & & & \\
\hline $\begin{array}{l}\text { COADJUVANTE } \\
\text { FEMININO }\end{array}$ & & & & & $\begin{array}{c}\text { GISELE } \\
\text { BERENGUEL }\end{array}$ \\
\hline CENOGRAFIA & & & & GRUPO TAL\&PÁ & \\
\hline ILUMINAÇÃO & & & & & $\begin{array}{c}\text { VINICIUS } \\
\text { ROSTELATO }\end{array}$ \\
\hline FIGURINO & & GRUPO & & & \\
\hline MAQUIAGEM & & & & & \\
\hline SONOPLASTIA & & & & $\begin{array}{l}\text { SORAIA DE } \\
\text { OLIVEIRA }\end{array}$ & \\
\hline $\begin{array}{l}\text { MELHOR } \\
\text { COREOGRAFIA }\end{array}$ & & & & ARIOVALDO JR & \\
\hline DIREÇÃO & & & & $\begin{array}{l}\text { VALÉRIA DE } \\
\text { OLIVEIRA }\end{array}$ & \\
\hline MELHOR ATOR & & EDSON PADILHA & & & \\
\hline MELHOR ATRIZ & $\begin{array}{c}\text { BRUNA CARLA } \\
\text { AGUIAR }\end{array}$ & & & & \\
\hline $\begin{array}{l}\text { MELHOR } \\
\text { PESQUISA } \\
\text { TEATRAL }\end{array}$ & & & $\begin{array}{l}\text { A CARA DO } \\
\text { BRASIL }\end{array}$ & & \\
\hline $\begin{array}{l}\text { MELHOR } \\
\text { ESPETÁCULO JURI } \\
\text { POPULAR }\end{array}$ & & & $\begin{array}{l}\text { A CARA DO } \\
\text { BRASIL }\end{array}$ & & \\
\hline $\begin{array}{l}\text { MELHOR } \\
\text { ESPETÁ́CULO }\end{array}$ & & QUIXOTE & & & \\
\hline $\begin{array}{l}2^{\circ} \text { MELHOR } \\
\text { ESPETÁCULO }\end{array}$ & & & & $\begin{array}{l}\text { O ÚLTIMO } \\
\text { CARRO }\end{array}$ & \\
\hline
\end{tabular}




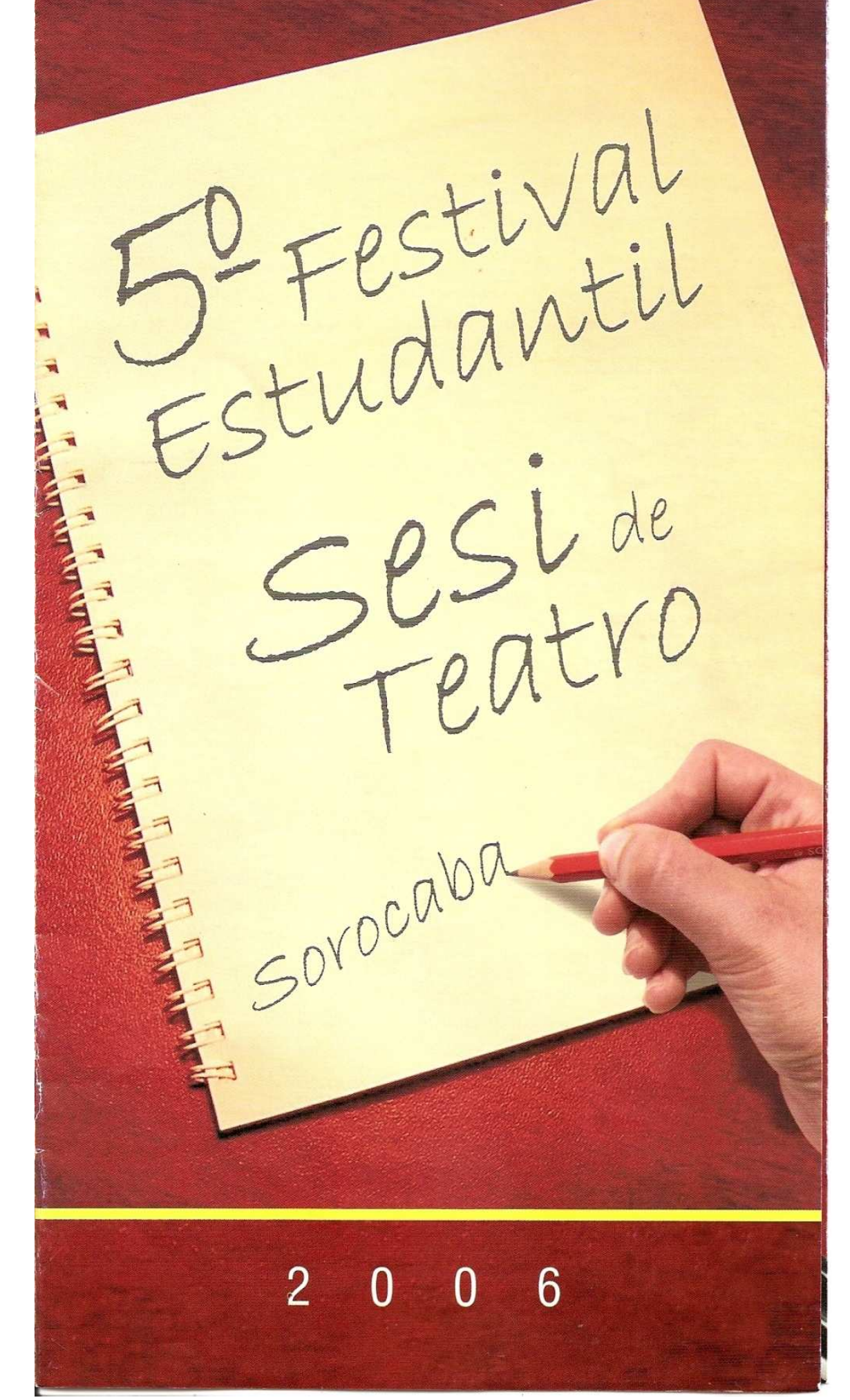




\section{5ํㅜ Festival Estudantil Sesi de Teatro - 2006}

No $5^{o}$ Festival Estudantil, partirmos para uma nova categoria a chamada categoria "livre", formada por estudantes que após a conclusão do ensino fundamental e médio ficavam impedidos de participar do festival estudantil e também nessa categoria poderiam ser englobadas as escolas de teatro. Os espetáculos foram analisados por Keren Mellone, Clóvis Garcia e Elizabeth Hartman $^{17}$

Nesse $5^{\circ}$ festival, propusemos a realização de mesas de reflexões sendo: Os Caminhos do Teatro Paulista pelo professor Clóvis Garcia; As Aventuras do Professor Artista pelo professor José Simões; A Arte Levada a Sério pelo artista Camilo Torres; A Profissionalização do Teatro Via Acadêmica pela professora Marli Bonome; O Jogo com estética e Pedagogia pela professora Ingrid Koudela. Uma inovação nesse festival também foi a de podermos contar com a curadoria de Ingrid Koudela. O que mais se sobressaiu durante todo o festival foi o desempenho e a maturação pelos que os grupos vêm passando mostrando o papel do Festival Estudantil. Contamos com três espetáculos por dia,o que foi um pouco desgastante, pois era muita informação para um dia só.

Novos grupos comparecem e alguns deixam de participar, mas se percebe também nesse $5^{\circ}$ Festival o entusiasmo e interesse dos participantes. No último dia, juntamente com os participantes, foi feito uma reunião para uma reflexão e avaliação do festival que se mostrou muito positiva, principalmente, sobre as mesas temáticas e um questionamento foi levantado sobre a premiação. Até que ponto ela se faz necessária, devemos repensar muito essa questão. Percebo também que para a instituição, o Festival acaba atrapalhando a rotina e andamento do espaço físico por conta dos alunos alojados e da grande movimentação durante sua realização, mudando a rotina da cozinha e de todo o funcionamento do Centro de Atividades. Isso, sem dúvida, passa ser uma preocupação para futuras edições dos festivais. 161

17 Formada pelo Curso de Arte Dramática da Faculdade de Filosofia da Universidade do Rio Grande do Sul. Ė atriz e diretora já tendo participado de várias novelas como, "Razão de Viver", "Dona Flor e seus dois Maridos" e "A Pequena Travessa". 
TUCUNARÉ, A FILHA DA LUA

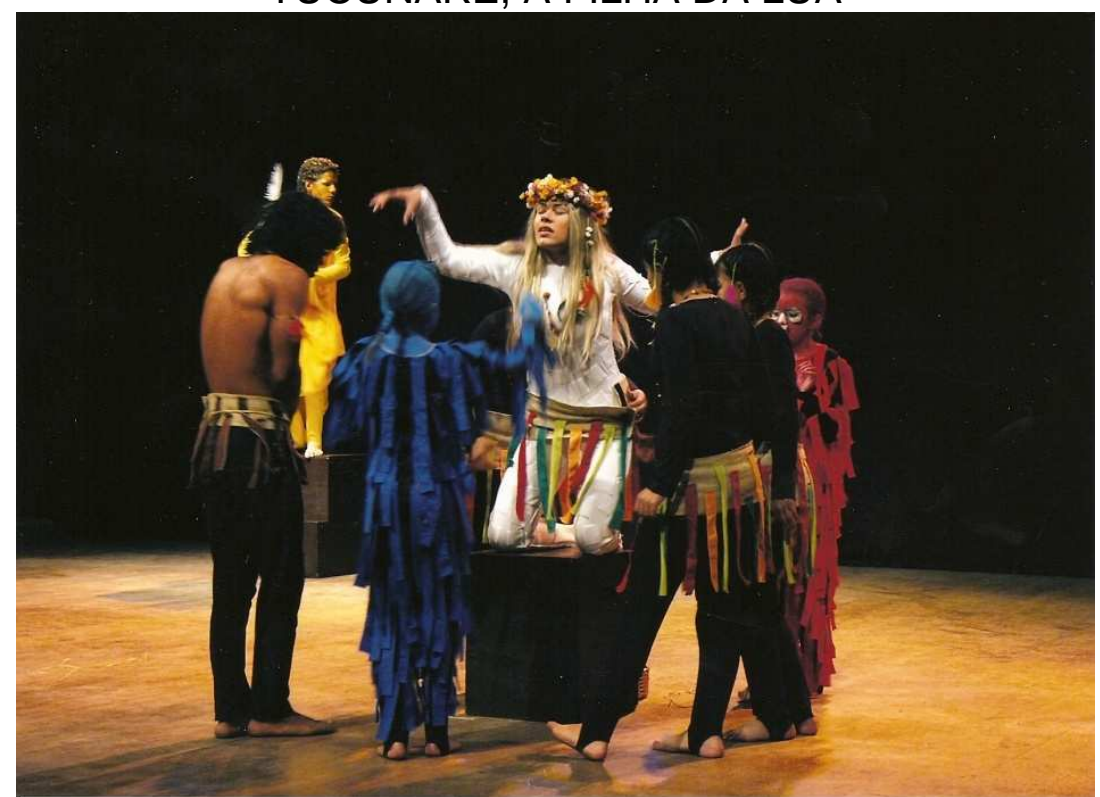

Autor: Ronaldo Ciambroni

Grupo: Cia. De Teatro Uta

Escola: E.E.Dr. Afonso Vergueiro

Cidade: Salto de Pirapora.

O espetáculo da escola Dr. Afonso Vergueiro, com a direção da professora artista Jane Kastorski, trouxe uma lenda indígena, resultante de um grande processo de pesquisa realizada pelos alunos. As dificuldades não são muitas, pelo que relata o grupo; o apoio da escola e da cidade é muito presente e importante para eles. Vale ressaltar que o grupo já esta formado há três anos e há dois, tem uma nova formação, e é a terceira vez que participa deste festival. Tudo foi construído a partir de sugestões dos alunos, embora o espetáculo não se aproxima muito do público, as crianças se desprendem um pouco. Durante o debate, questões como: escolha do texto e a função de alguns atores em cena sem interpretação foram levantadas, mas o que se nota claramente é o amadurecimento do grupo e, principalmente, a diferença dos primeiros trabalhos apresentados aqui neste festival. 


\section{RELEASE}

É uma lenda indígena. O sol e a lua tiveram uma filha (que era uma luz) e depositaram essa luz numa gigante vitória-régia do Amazonas, para que ela protegesse a mata. Tucunaré foi criada pela tribo dos tucanos e transformouse, então, na guerreira defensora da mata, símbolo da ecologia.

Direção: Jane Kastorsky

\section{FICHA TÉCNICA E ARTÍSTICA}

Maquiagem: Marcelo Bernini

Cabelo: Rode Barrabella

Sonoplastia: Jane Kastorsky

Operadora de som: Jane Kastorsky

Iluminação: Felipe Nóris

Operador de Luz: Felipe Nóris

Figurino: Jane Kastorsky e Angélica Leme

Cenografia: Dorival de Souza

Músicos: Banda Municipal de Salto de Pirapora Cafú, Jean e Robson

Fotografia: A. Tozze

Preparação Física: Sueli Anhaia.

Gisele Gomes

Angélica Leme

Daiane Fernandes

ELENCO

Deca Moreira

Elisa Santana

Evelin Ferreira

Franciele Anhaia

Jéssica Oliveira

Keli Dias

Leandro Alves

Lucas Leah

Mariana Avanzz

Pâmela Bueno

Reinaldo Cruz

Zeca Campos. 
GERAÇÃO COCA-COLA

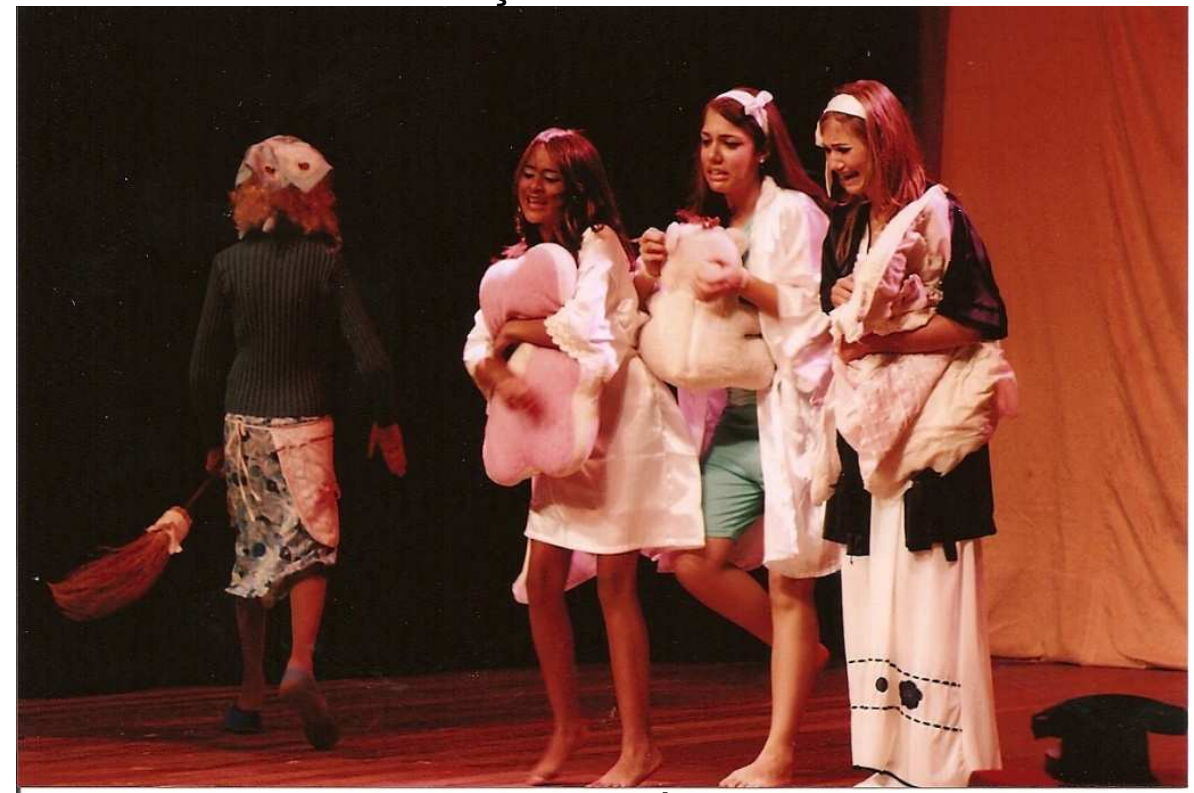

Autor Ronaldo Ciambroni / Adaptação de Érika Bodstein com textos próprios e outros retirados da peça "Namoro". De líder Miranda Costa)

Grupo: Teatro Cil

Escola: Colégio Imperatriz Leolpoldina

Cidade: São Paulo

O espetáculo do grupo CIL do Colégio Imperatriz Leopoldina, da cidade de São Paulo, participa pela primeira vez deste festival, o trabalho bem elaborado, com um figurino assertivo, cenografia bem realizada fez com que 0 grupo tivesse um desempenho que favoreceu muito o espetáculo. A professora artista Érika Bodstein trabalha com os alunos, na própria escola, com matéria de teatro, mas a montagem é extracurricular. Durante o debate, um jurado se manifestou elogiando a montagem e a escolha do texto pela idade dos atores. 


\section{RELEASE}

O espetáculo conta a história de um grupo de jovens adolescentes e suas aventuras escolares e amorosas no Brasil das décadas de 1950 e 1960. Todo o panorama mundial e brasileiro do período é mostrado através de seus jovens personagens, suas aspirações, ilusões, amores, amizades, tudo com muita alegria e bom humor, ao som das baladas românticas da época e principalmente de muito rock' in roll.

Direção: Érika Bodstein

\section{FICHA TÉCNICA E ARTÍSTICA}

Iluminação e Trilha Sonora: Érika Bodstein

Figurinos: Mariana Camargo

Técnico de Luz: Marco Piá

Técnico de som: Mariana Camargo

Maquiagem: Tatinha Bernardes.

Aline de Fátima Feola

ELENCO

Amanda Pessoa Mendes

Juliana Ostini

Lais Paulon Sautchuk

Parmisciano

Augusto Ruy Machado

Bárbara Zomer da Fonseca

Bernardo Bastos Pereira dos

Santos

Larissa Patta Pereira

Laura Carlos Delbianco

Laura Michelin Morcelli

Lia Rodrigues Rufino

Marília Beatriz Gomes

Carolina Rateiro Preira

Martin Müller Anselment

Caroline Aparecida Fernandes

Natalia Santana Zuccala

Felipe Luís Fachin

Felipe Nutti Giannastasio

Tamires Boschini Dobischa

Humberto Tozzi

Tatiana Borges de Souza

Vitor Mello Cantagesso 


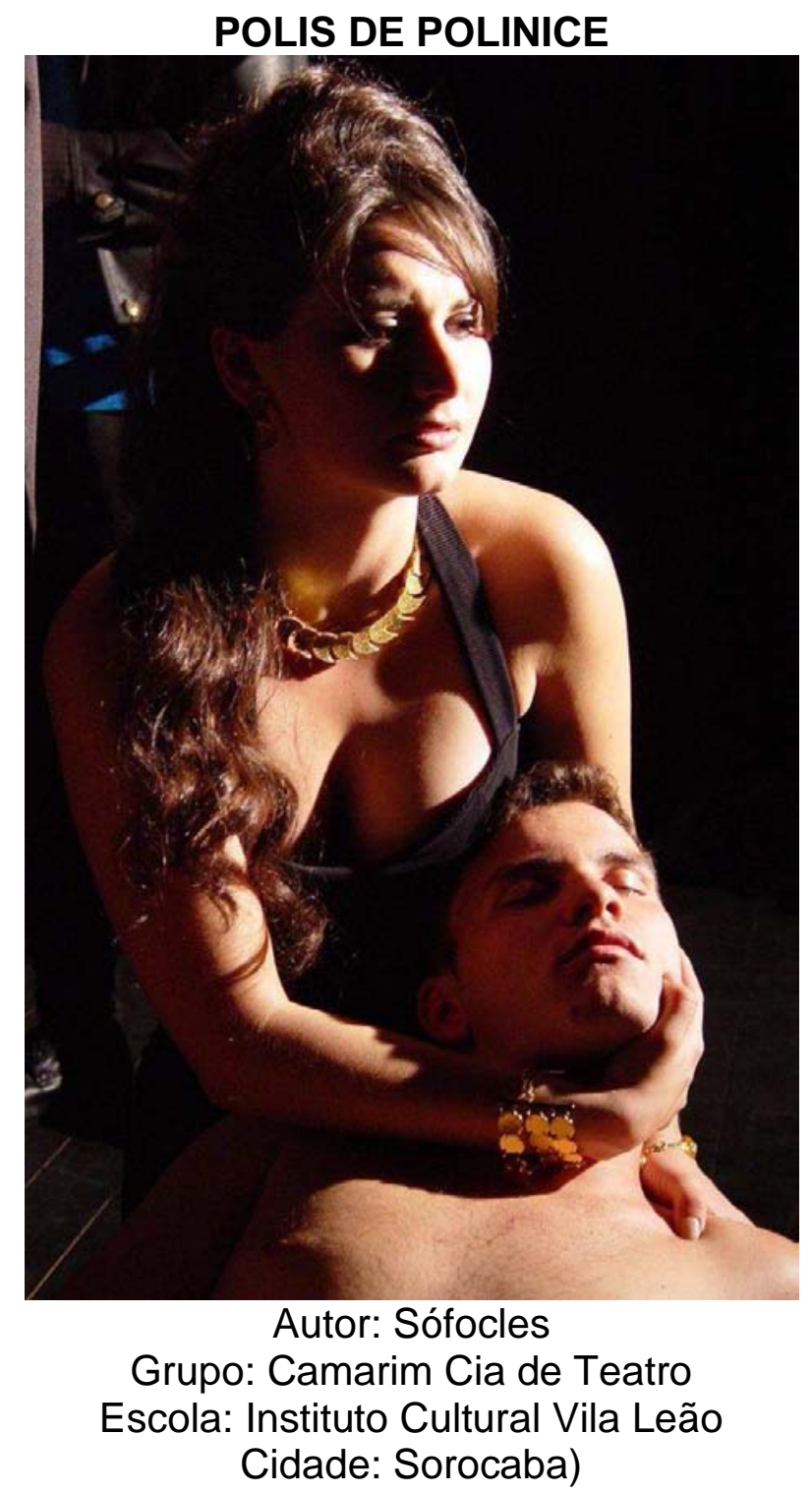

Da Cia Camarim de Teatro, da cidade de Sorocaba, o espetáculo tentou trazer uma tragédia grega, mas não foram felizes na adaptação do texto. O que se destaca foram os penteados das atrizes, mas que não condizem com a cenografia, figurino e principalmente com as interpretações do atores. Durante o debate o espetáculo foi muito criticado pela maneira que foi concebido e do equívoco da adaptação. 


\section{RELEASE}

Baseada na tragédia grega Antígona, a montagem exalta a coragem de Antígona enfrentando seu tio Creonte, um governador tirano, arriscando sua própria vida em nome de um princípio.

Direção: Hamilton Sbrana

\section{FICHA TÉCNICA E ARTÍSTICA}

lluminação: Aleixo Billy

Sonoplastia: Marcos Ivers

Figurino: O Grupo

Operador de Som: Marcos Ivers

Operador de Luz: Lucila Vieira.
Carlos Doles
Diana Oliveira
Lucila Ressa
Jairo Leme
Liane Nicoley
Pedro Fontes
Richard Godoy
Wagner Bernardo
Tiago Moura
Jéssica Maragno
Ketlyn Azevedo

ELENCO
Aline Castelli
Moacir Gomes Júnior
Tiago Martins
Talita Rosa
Gabriele Vaz
Mariane Ribeiro
Michel Rodrigues
Tais Chanes
Gisele Almenara
Julian Camargo
Ramom B. Florentino 


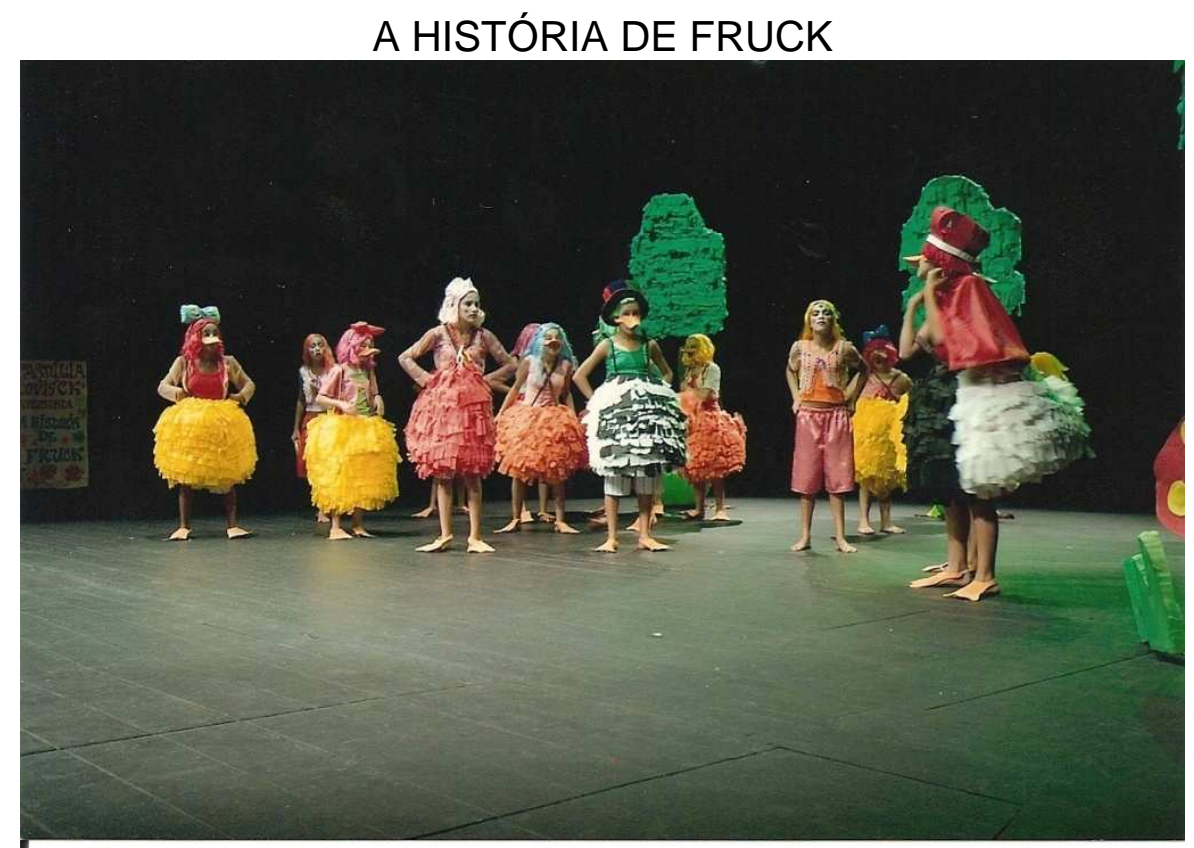

Autor: Cássia Lopes / Adaptação: Tânia Boy

Grupo: Teatral Tia Thereza \& Cia.

Escola: EE Dr. Gualberto Moreira Cidade: Sorocaba.

Do grupo Tia Thereza, dirigido pela professora artista Tânia Boy, o espetáculo feito por criança para criança, contagiou o público, com figurino de muito bom gosto, que trazia imediata identificação das crianças com o espetáculo. É a quarta vez que este grupo participa do festival e o crescimento do grupo e notável, percebe-se ainda muita pesquisa por parte da direção. Durante o debate, os jurados elogiaram muito a escolha do texto e a maneira como foi construída a montagem. 


\section{RELEASE}

O espetáculo é uma comédia musical encenada pela família Patovisk. Eles apresentam a história de um patinho que é diferente dos outros e por isso é discriminado na Patolândia, lugar onde vivem. Então ele decide procurar o Pato-Rei na floresta, pois acredita que ele pode transformá-lo num pato igual aos outros. Nessa aventura, conhece outros bichos e com eles descobrem suas próprias qualidades, mas também encontra uma onça faminta que quer devorá-lo. Fruck enfrenta muitos perigos, aprende a dar valor ao seu jeito de ser e percebe que os outros devem aceitá-lo como ele é.

\section{FICHA TÉCNICA E ARTÍSTICA}

Direção: Tânia Boy

Assistência de direção: Camila

Rocha

Iluminação e Cenografia: Tânia Boy

Sonoplastia: Tânia Boy e Camila

Rocha

Figurino: Maria Aparecida Ribeiro e

Tânia Boy

Ágata Galdino

Alessandra Marconi

Amanda Engler

Ana Heloísa Fontes

Bianca Farias

Érica Guizardi

Jéssica Medeiros

Moníque Novaes
Coreografia e Maquiagem: Camila

Rocha

Operação de Som: Daiana Ramos

Operação de Luz: Rodrigo Ferrary

Contra-Regra: Wagner Boy, Jéssica

Saez, Marisa Campos, Laura

Ribeiro, Júlia Ribeiro e Diego Kenit.

\section{ELENCO}

Mickaelly Mota

Nadine Marca

Dríely Ferreira

Nádia Gallio

Nathália Corrêa

Núbia Cavalcante

Talita Albanez 


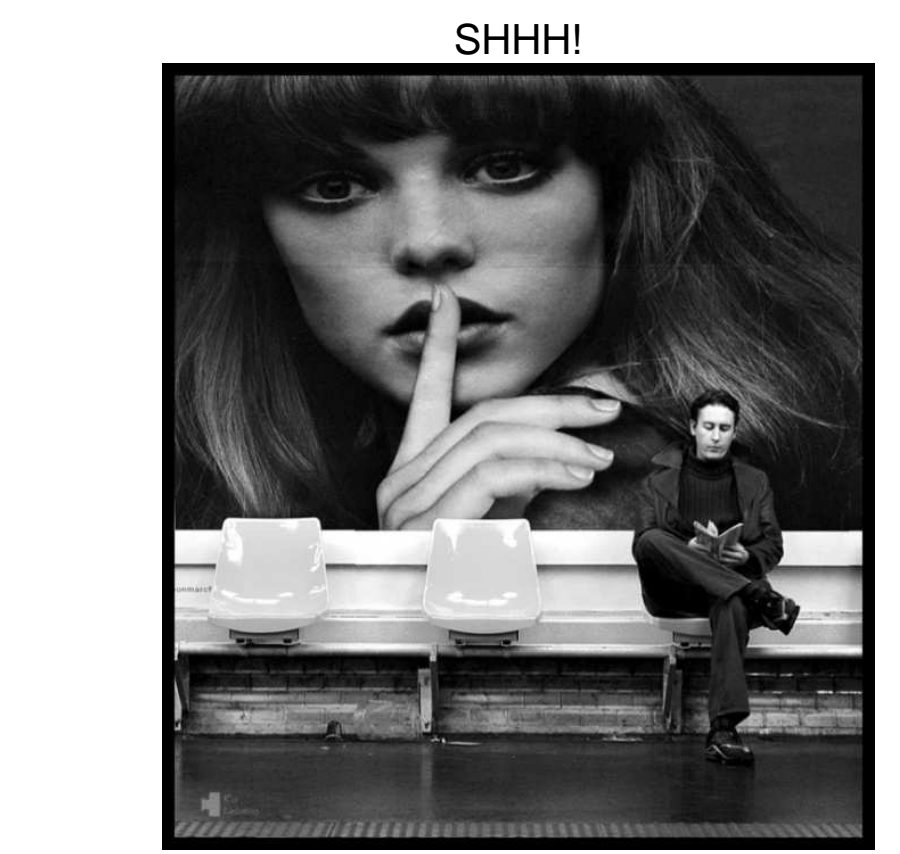

Autor: Tennessee Williams e Caio Fernando de Abreu/

Grupo: Cia. Cavalo de Tróia

Escola: EE Jardim Primavera

Cidade: Salto de Pirapora.

O grupo Cavalo de Tróia, com direção de Juliano Casimiro, fez um espetáculo com adaptação da obra de Tennessee Williams e Caio Fernando de Abreu. O espetáculo ficou monótono, não tinha uma linha conceitual definida e o elenco não sabia o que estava falando. O espetáculo pecou pelo excesso de cenografia e músicas. Durante o debate, a montagem foi muito criticada e questões como adaptação e processos de trabalho foram levantadas. O diretor participou do $1^{\circ}$ Festival Estudantil e só agora no quinto retornou para participar. 


\section{RELEASE}

O espetáculo $S H H H$ ! parte da estrutura temática branda e contestadora de três textos de Tennessee Williams: Fala comigo doce como a chuva; Esta propriedade está condenada; Algo que não é falado. Explorando, cenicamente, a omissão social comum de temas "controversos" através de ações cotidianas que demonstram a passividade do homem perante certas situações embaraçosas e conflitantes.

\section{FICHA TÉCNICA E ARTÍSTICA}

Iluminação, Cenografia, Produção, Sonoplastia: Juliano Casimiro Figurino: Juliano Casimiro e Karen Costa Cabelo: Karen Costa Operador de Luz: Bruno Neres Operador de som: Allyson Conventti Música e Pesquisa Sonora: Jackson Produção executiva: Bruno Neres Emílio Arte Gráfica: Jonatas Viana Assistente de produção: Denise Vieira e Gérica Branco Cenotécnica: Vinícis Rostelato. Maquiagem: Karen Costa Bruno Neres e Lays Cardinali.

Denise Vieira Jackson Emílio Paulo Victor Daniel Vinícius Rostelato Gérica Santos Lays Cardinali Gisele Berenguel 
A TÁVOLA REDONDA

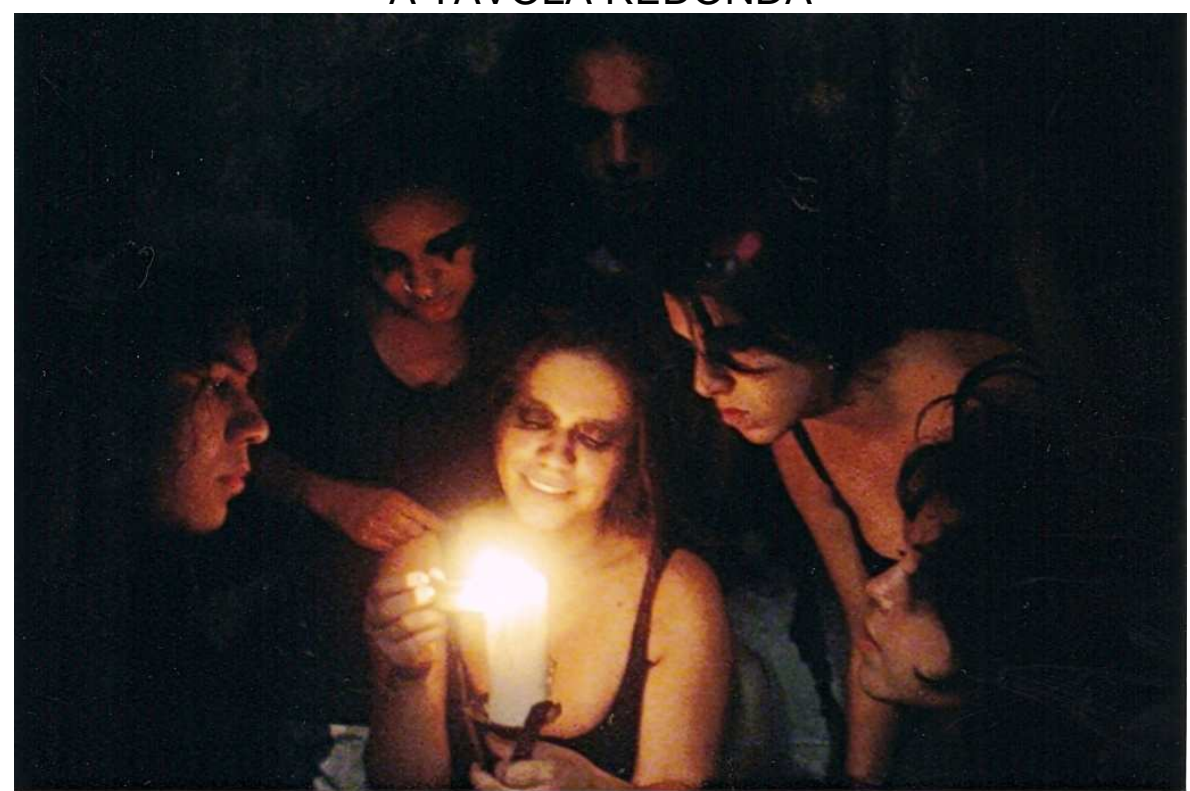

Adaptação do livro Merlin ou a Terra Deserta, do alemão Tankred Dorst

Grupo: Teatro Singular

Escola: Colégio Singular

Cidade: Santo André

Da Cidade de Santo André, do Grupo do Teatro Singular, o trabalho desenvolvido pelo professor artista Marcelo Gianini trouxe para o palco um teatro inovador com figurino que funcionava muito bem, imagens eram inseridas durante o espetáculo de uma maneira sutil e faziam com que todo o público embarcasse na história. O professor artista trabalha com o grupo no colégio há muitos anos e esse trabalho é extracurricular. É a primeira vez que o espetáculo participa do Festival. Durante o debate, o espetáculo foi bem elogiado. 


\section{RELEASE}

Décimo espetáculo do grupo de Teatro do Colégio Singular (o nosso teatro singular), Távola Redonda é uma reflexão sobre o que parece ser o fim das utopias. Usando como fábula as lendas do Rei Artur e seus cavaleiros na criação da Távola Redonda, isto é, da democracia possível para época, o espetáculo do Teatro Singular explora as relações entre o Mago Merlin e seu pupilo, o rei e seu filho Mordred.

Direção: Marcelo Gianini

\section{FICHA TÉCNICA E ARTÍSTICA}

Contra-Regras: Christian Pina, Marcelo Gianini, Irina Serrano

Iluminação: Caio Lacerda

Produção de Imagens: Caio Lacerda e Heloísa Alvarez

Figurino: Renata Soarez

Cenografia: Marcelo Gianini

Adereços: Teatro Singular

Sonoplastia: Dj Marc François

Produção Gráfica: Tales Monteiro

Produção: Colégio e Teatro Singular

Caroline Ferraresi

ELENCO

Heloísa Alvarez

Lígia Helena

Leonardo Reitano

Luma Reis

Mariana Gulin

Paulo Gircys. 


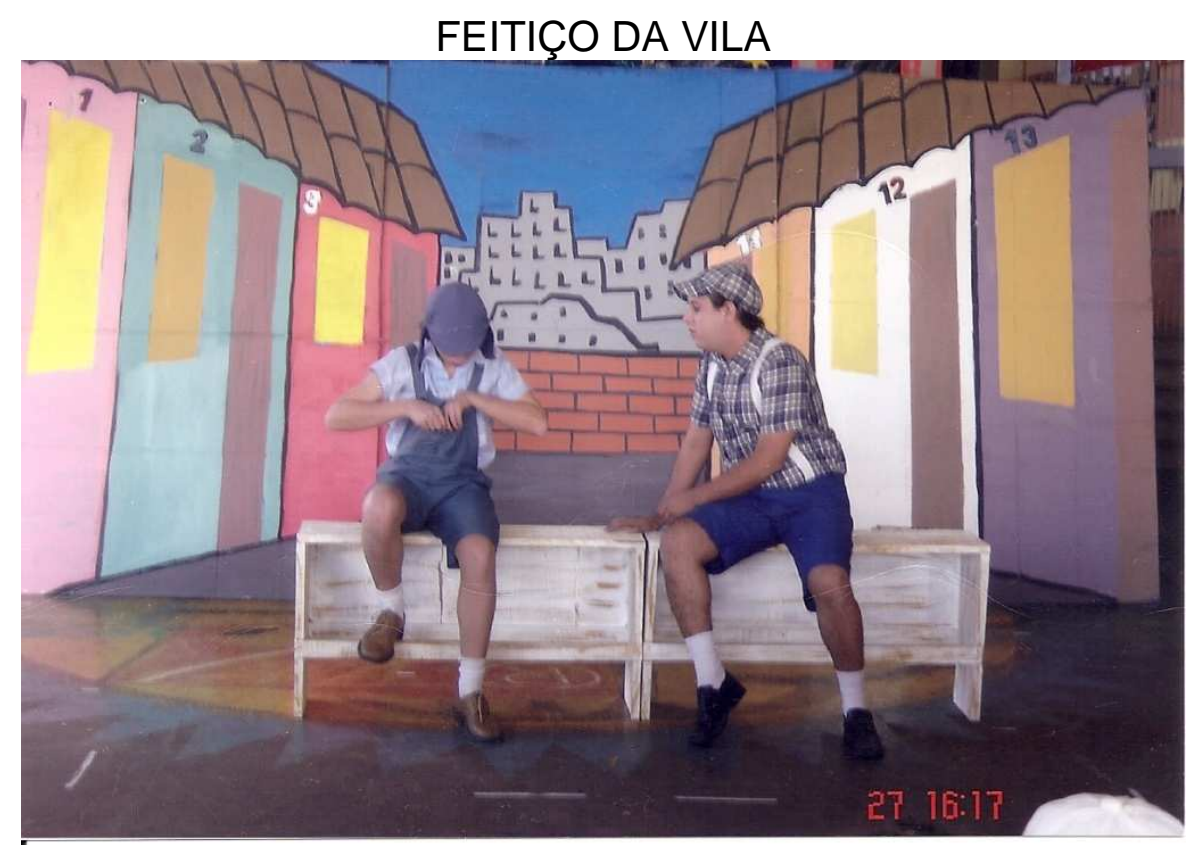

Autor: Cláudia Dallaverde e Zeca Cappellini

Grupo: Garagem \& Cia.

Escola: EE Chico Pereira Cidade: Tatuí.

Do Grupo Garagem e Cia, da escola estadual Chico Pereira, da Cidade de Tatuí, embora a escola tenha participado desde o primeiro festival, esta formação é totalmente nova e seus integrantes participaram pela primeira vez. O espetáculo, feito para criança, tem um elenco de adultos interpretando crianças, o que fica um pouco prejudicial à apresentação, pois as crianças da platéia não conseguem entender porque adultos imitam crianças. $O$ espetáculo teve a direção do prof. artista Luis Fernando Moura que também interpreta o personagem principal do espetáculo. Durante o debate, a comissão julgadora questionou a atuação de adultos no papel de crianças. Uma pergunta que foi pertinente é a de não existirem crianças na escola querendo fazer teatro. 


\section{RELEASE}

A chegada de uma menina a uma vila, onde só moram meninos, cria uma situação de competição que se transporta para o mundo da fantasia. A conclusão da história se dá no plano real, quando a princesa encantada abandona a atitude passiva de Bela Adormecida e faz a sua escolha independente do resultado da competição.

Direção: Luiz Fernando Moura

\section{FICHA TÉCNICA E ARTÍSTICA}

Cenografia: Marcos Antunes

Cenotécnica: Marcos / Coelho Lobo

lluminação: Rogério Almeida e Maria Helena Miranda

Figurino: 0 Grupo

Maquiagem: Luiz Fernando Moura

Equipe de Maquiagem: Letícia Santana e Francielly Andrade

Adaptação Musical: Rita Cássia e Luiz Fernando Moura

Sonoplastia: Quinteto Musical "Garagem \& Cia" Violão: Ronei Antunes Alegro, Percussão: Flávia Fernandes, Flauta: Marcus Vinícius Casemiro, Teclado: Bruno Costa, Baixo: Guilherme Gurgel

Contra-Regras: Jéssica Coração, Lara Gurgel Mirando e Renan Carriel

Direção Geral: Luiz Fernando Moura.

Luiz Fernando Moura

Marcos Felipe Pereira Vieira

Bruno Coração

Letícia Santana

Magno Dias
ELENCO

Victor Moura

Francielly Andrade

Clara Gurgel Miranda

Renan Carriel. 


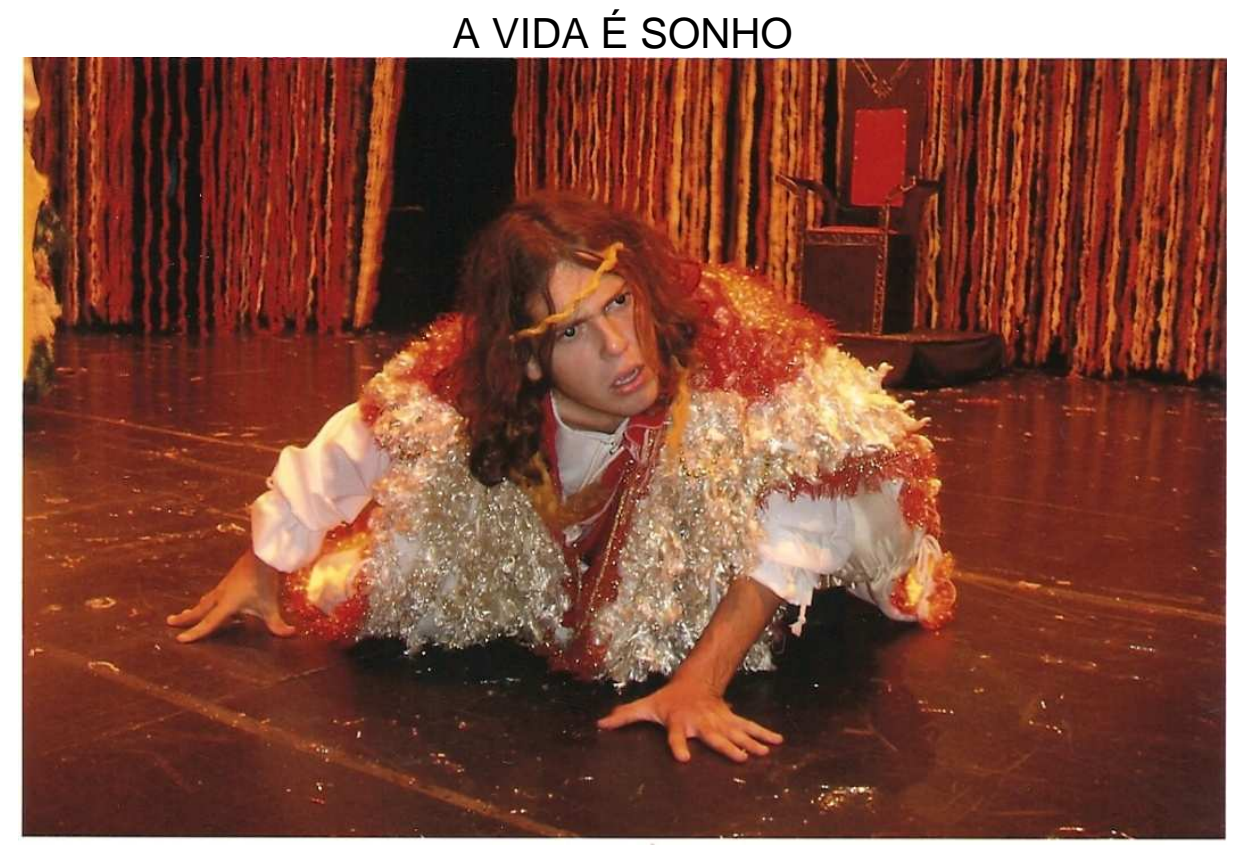

Autor: Pedro Calderón de La Barca

Grupo: Grupo de Teatro Missicrof

Escola: EE Prof. ${ }^{\text {a }}$ Irene de Assis Saes

Cidade: Santa Bárbara do Oeste

O Grupo de Teatro Missicrof, da Cidade de Santa Bárbara do Oeste, participa pela primeira vez do Festival, com esse espetáculo. O espetáculo não tem um processo muito definido, perde-se um pouco enquanto teatro desenvolvido nas escolas e é perceptível o despreparo do Professor Diretor, que comete vários equívocos. O espetáculo chega a ter duas horas e vinte minutos e a platéia se sente entediada por ver uma apresentação em que não se conecta figurinos, cenografia, música e interpretação. Durante o debate, a comissão julgadora enfatiza o mau trabalho desenvolvido, e uma das questões que foi levantada por um dos jurados é mais que parecia um desfile de moda de trajes antigos. 


\section{RELEASE}

$\mathrm{Na}$ Polônia, em uma época antiga e indeterminada, o príncipe Segismundo, vive trancafiado em uma torre desde que nasceu. Tudo isso porque seu pai, o velho Rei Basílio, acreditava ler as estrelas e previu que seu filho seria um homem destinado a crimes e desgraças.

Em certa altura da história, o Rei percebe que talvez tenha cometido um erro com tal atitude e resolve tirar o filho da prisão e testá-lo para ver se ele merece ser um herdeiro.

Direção: Kelvis Germano

Assistência de Direção: Silvia

Aparecida José e Silva e Driale Feliciano

Iluminação: Kelvis Germano

Cenografia: kelvis Germano

Figurinos: Kelvis Germano

Sonoplastia: Luis Fernado de Godoy

Coreografia: Daniel Margatto

Maquiagem: O Grupo

Operador de Som: Kelvis Germano

\section{FICHA TÉCNICA E ARTÍSTICA}

Operador de Luz: Silvia Aparecida José e Silva e Driale Feliciano

Pesquisa: Silvia Aparecida José e Silva, kelvis Germano e Luís Fernando de

Godoy

Professor Responsável: Silvia Aparecida José e Silva

Coordenação Pedagógica: Maria Vânia

Cayres e Carlos Ronaldo Cini

Direção Escolar: Valteci José Rodrigues

e Simeire Cristina Hackmann Ferreira.

\author{
Alessandra Benelle \\ Bruno Mascarenhas \\ Danilo Dias da Silva \\ Débora Luisa Marturano \\ Érika Pinto Teles dos Santos \\ Flávia Falasca da Silva \\ Giovane de Araújo Dias \\ Júlia Cavichioli Naline
}

\section{ELENCO}

Larissa Silva Duarte

Matheus Rodrigues dos Santos

Patrícia Francisco de Gois

Plínio Antônio Ferreira da Silva

Tatiane Naiara Bessão de Souza

Thatiane Cristina da Silva 


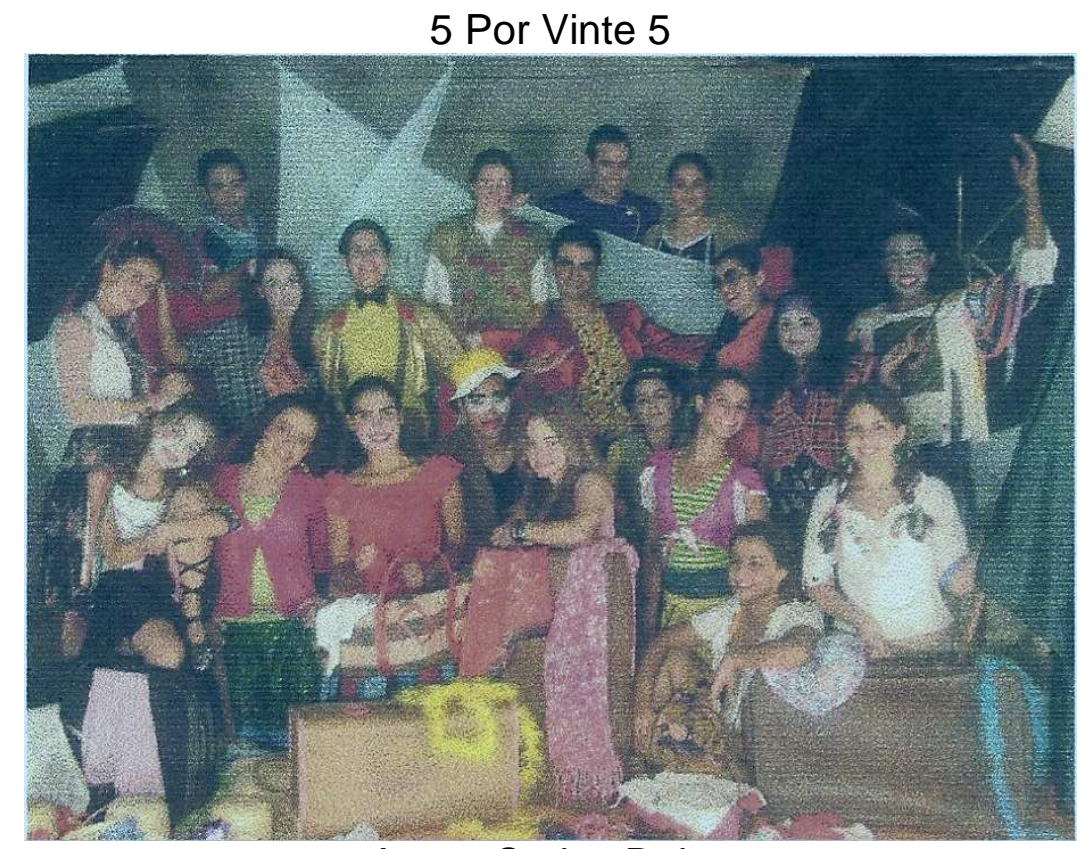

Autor: Carlos Doles

Grupo: Núcleo Descobrir Teatro

Escola: Associação Cultural Grupo Manto

Cidade: Sorocaba

Da companhia Núcleo Descobrir Teatro, da Cidade de Sorocaba, o espetáculo visitou cinco bairros da cidade tendo rápida identificação com a platéia, pois estava falando do que todos conheciam e o elenco sabia muito bem do assunto que abordava. A peça é de direção e autoria do professor artista Carlos Doli, contagiou o público através de uma trilha sonora envolvente e um cenário que levava o espectador para um universo que eles se propunham a mostrar. Durante o debate, os jurados mencionaram a felicidade pela escolha do texto e pelos processos de trabalho. 


\section{RELEASE}

Cinco malas, cinco temas, cinco bairros e muitas vidas! O que acontece quando vinte e cinco atores-contadores se juntam para levar cinco malas com muitas histórias.

\section{FICHA TÉCNICA E ARTÍSTICA}

Direção: Carlos Doles e Fábio Fiorelli

Trilha Sonora: Fábio Fiorelli

lluminação: Carlos Doles

Operador de Som e Luz: Vinícius Mageta

Figurino: O Grupo

Cenário: O Grupo

Adereços: O Grupo

Maquiagem: O Grupo

Supervisão e Apoio: Fábio Fiorelli

Adriane Fernanda

Aline Duarte

Ana Morelli

Bruna Arruda

Camila Isquierdo

Carlos Belo

Carol Vieira

Daniel Gouveia

Diego Fogaça

Fernando Alcântara

Isa Santos

\section{ELENCO}

Julian Camargo

Juliana Ghiselini

Marco Antônio Rodrigues

Mariana Peres

Melína Aronchi

Neto Gonçalves

Símone Arcuri

Stephany Nayara

Talita Rosa

Viviane Munhoz 


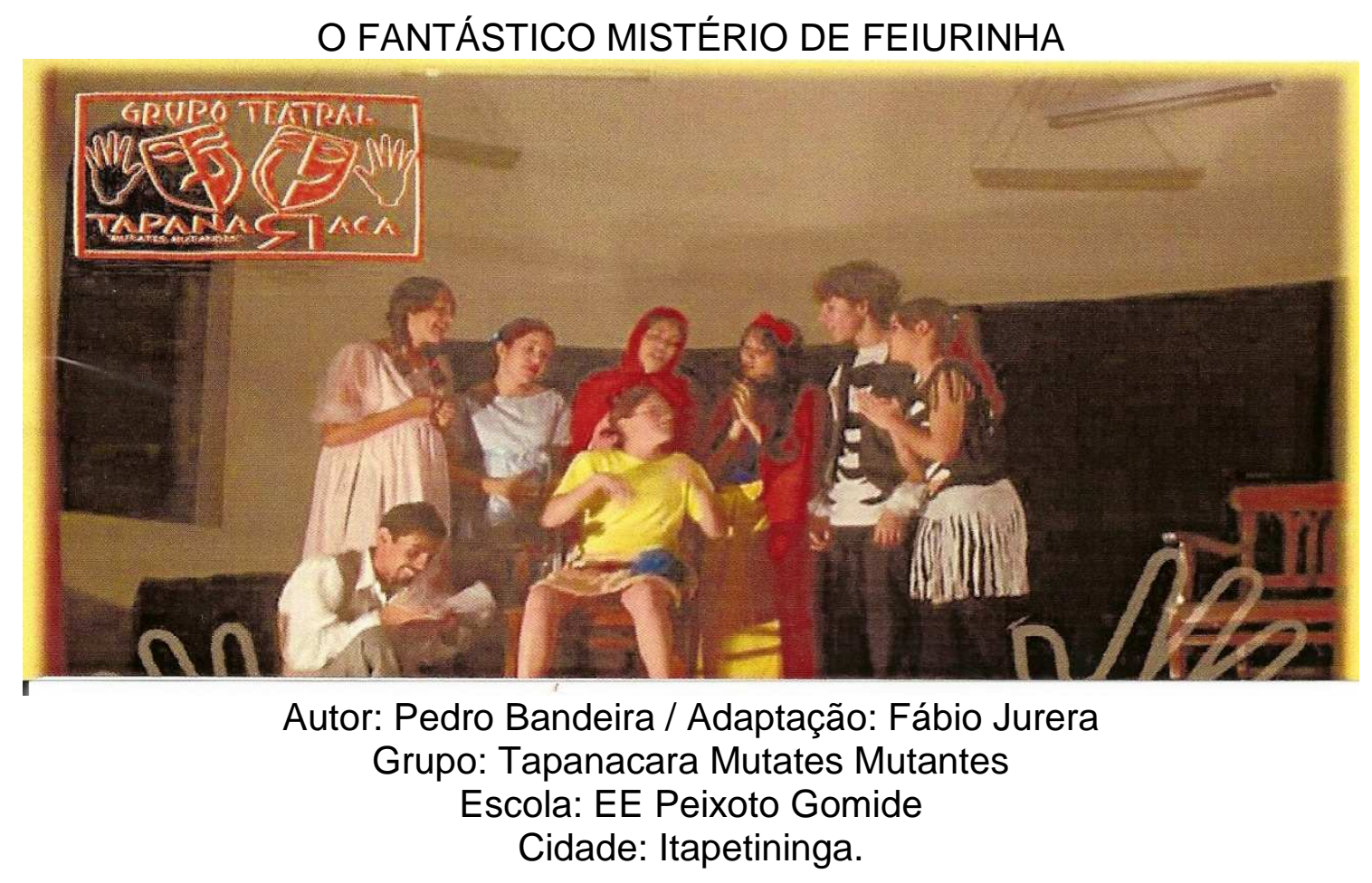

Com direção do professor artista Fábio Juréra, da Escola Peixoto Gomide, sendo o segundo ano que o grupo participa desse Festival. O grupo trouxe um espetáculo que teve alguns acertos, dentre eles: cenografia e figurinos. A adaptação feita pelo próprio Fábio ficou um pouco confuso, mas as crianças gostaram. É um espetáculo que precisa ser revisto, pois se percebe o grande esforço do grupo que está presente por meio dos jogos, a todo o momento, no processo de trabalho, o que deixa a interpretação dos atores muita bem equilibrada. Durante o debate, os jurados contestaram um pouco a adaptação e apontaram alguns caminhos de pesquisa. 


\section{RELEASE}

Branca de Neve reúne Cinderela, Chapeuzinho Vermelho e Rapunzel em seu castelo para desvendar o misterioso desaparecimento de sua cunhada Feiurinha Encantada. Branca ordena a Caio e Colombina, seus lacaios, que procurem a princesa por toda parte.

Saindo pelo mundo atrás de todos os grandes escritores de contos infantis, eles vão parar no escritório de um que passa a ser personagem de própria história. Porém nem o renomado escritor conhece a tal princesa Feiurinha Encantada. Finalmente, o mistério é desvendado por Gerusa, empregada do escritor, que ao contar a história eterniza Feiurinha e encanta espectadores de todas as idades.

Diretor: Fábio Jurera

\section{FICHA TÉCNICA E ARTÍSTICA}

lluminador: Lucy Villar

Cenógrafo: Elton Cunha

Sonoplasta: Sandra Rogério

Contra-Regra: Arthur Ferrarezi

Figurinista: Lucy Villar

Maquiador: Haya Medeiros.

W.W. Gomes

Haya Medeiros

Jhonny Medeiros

Jéssica Menezes

Ana Dias

Elis Regina
ELENCO

Jéssica Oliveira Amanda Kaurnick Kamila Kaurnick Anderson Thiago Daniele Ayres Rafael Rodrigues 


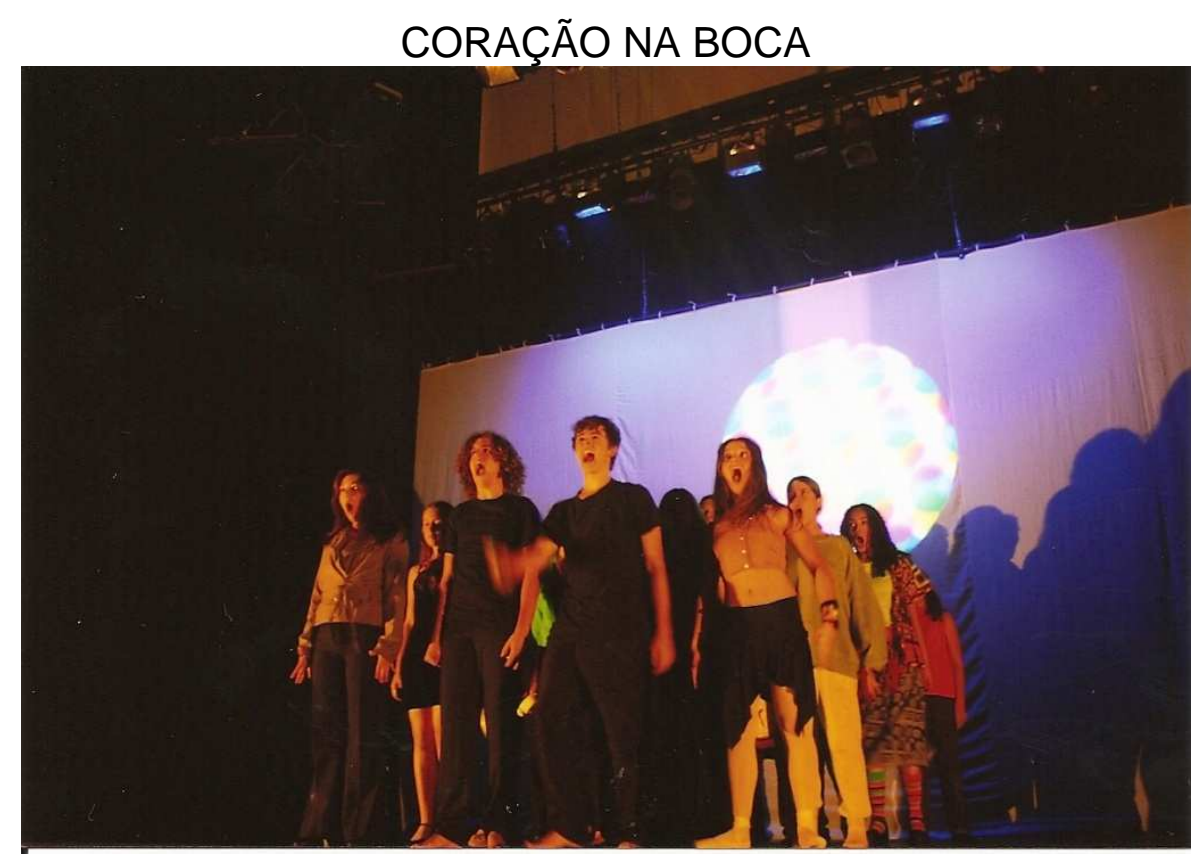

Autor: O Grupo

Grupo: Carpe Diem

Escola: Colégio Emece

Cidade: São Paulo

Grupo Carpe Diem, do colégio EMECE, com direção da professora artista Valéria Marche, participando pela primeira vez do festival com 0 espetáculo criado a partir de temas discutidos em sala de aula. Os alunos tinham propriedade em suas interpretações, o que ficou muito claro durante a apresentação. Tudo se encaixava muito bem, figurinos e o espaço cênico que era demarcado com a iluminação. Durante o debate, a comissão julgadora elogiou o processo de trabalho e a formatação do texto. 


\section{RELEASE}

O espetáculo Coração na Boca é uma adaptação feita partir de textos curtos de autores como Harold Pinter, lonesco, o psiquiatra R.D. Laing, além de cenas criadas pelos próprios alunos a partir de temas discutidos em aula. $O$ tema do espetáculo é a solidão, a falta de amor, as desigualdades sociais, as relações familiares que permeiam a vida das pessoas nas grandes metrópoles como São Paulo.

Direção: Valeria Marchi

\section{FICHA TÉCNICA E ARTÍSTICA}

Iluminação: Érika Bodstein

Trilha Sonora. Valeria Marchi

Figurino O Grupo

Técnico de som: Marco Poá

Técnico de luz: Beto Bellinatti

Maquiagem: Regina Carmona

André Furegati de Carvalho

Bárbara Molnar

Camila Araújo

Camila Galupo Lourenço

Camila Antiquera Silva

Esther Simões Toledo

Gabriela Pinheiro Mondim

Iratã Lisboa Rocha Campos

\section{ELENCO}

Jéssica Simões Tolefo

Lana Lima L. Rocha

Mariana Machado

Paula Rocha Tava

Priscila Muniz

Rômulo Villela Ponte

Yasmine G. C. Gonçalves 


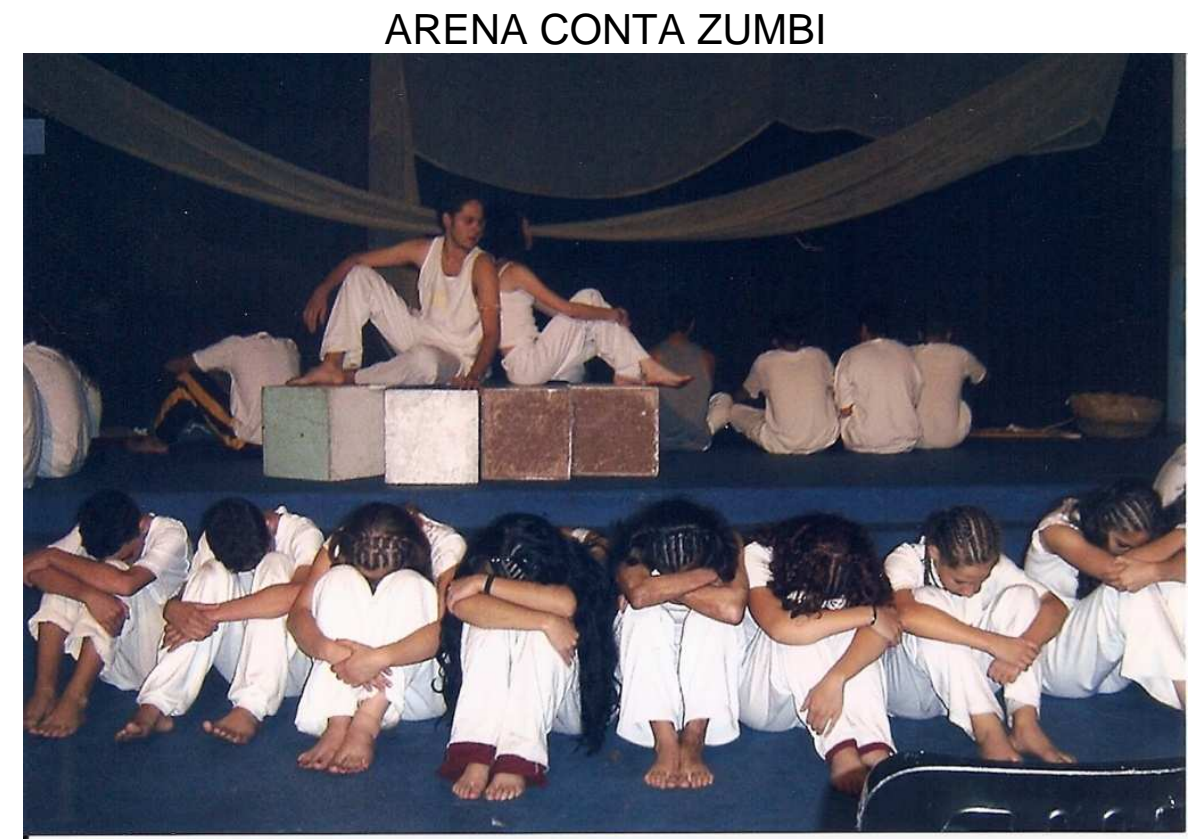

Autor: Gianfrancesco Guarnieri, Augusto Boal e Edu Lobo Grupo: Tal\&Pá

Escola: EE. Prof ${ }^{a}$. Maria Augusta de Ávila Cidade: São Paulo

O grupo Tal\&Pá se faz presente, pela terceira vez, com a direção da professora artista Valéria Oliveira, num espetáculo que emociona e contagia toda a platéia e pode-se perceber visivelmente o processo de trabalho. Os atores sentem prazer de estar em cena e cada vez mais se percebe o quanto a comunidade local, onde está instalado o grupo, vem ganhando com esse trabalho, um espetáculo que prima pela simplicidade. A comissão julgadora apontou pontos favoráveis e positivos ao espetáculo. 


\section{RELEASE}

Reflete outra forma de engajamento político: a do militante negro nos processos sociais. Revela um ponto de vista humano, capaz de romper as fronteiras da raça.

\section{FICHA TÉCNICA E ARTÍSTICA}

Direção Valéria de Oliveira Coordenação Técnica: Carina Viana Cenografia: O Grupo lluminação: Alexandre Naves e Juliana Martins Operador de Som: Henrique Chorão Contra-Regras: Tony Leão Nunes e

Tati Fabrício

Figurino: O Grupo Maquiagem: O Grupo Pesquisa: O Grupo
Preparação Corporal: Alairton Lopes Coreografia: Ariovaldo Júnior Músicos: Carina Viana, Jonatan Souza Danielton Rodrigues, Soraya de Oliveira, Sheriton Silva / Secretária: Juliana Martins Apoio: Helena de Oliveira, Eliana Mendes, Simone Ferraresi Motorista: Paulinho.
Alairton Lopes

Aline Oliveira

Aline Rodrigues

André Abbenante

Angela Anthea

Ângelo Favero

Caio Nunes

Camila Nabarro

Cristiana Fabrício

\section{ELENCO}

Débora Hathner

Fábio Júnior

Hebert Almeida

Itamar Fernandes

Katyenne Lima

Keí Lima

Letícia Santos

Lúcia Leão Nunes

Luís Fernandes
Marcos Vinícius

Nathália Silva

Rafael Fabrício

Rafael Riglei

Renan dos Santos

Wagner de Freitas

Wesley Andrade 


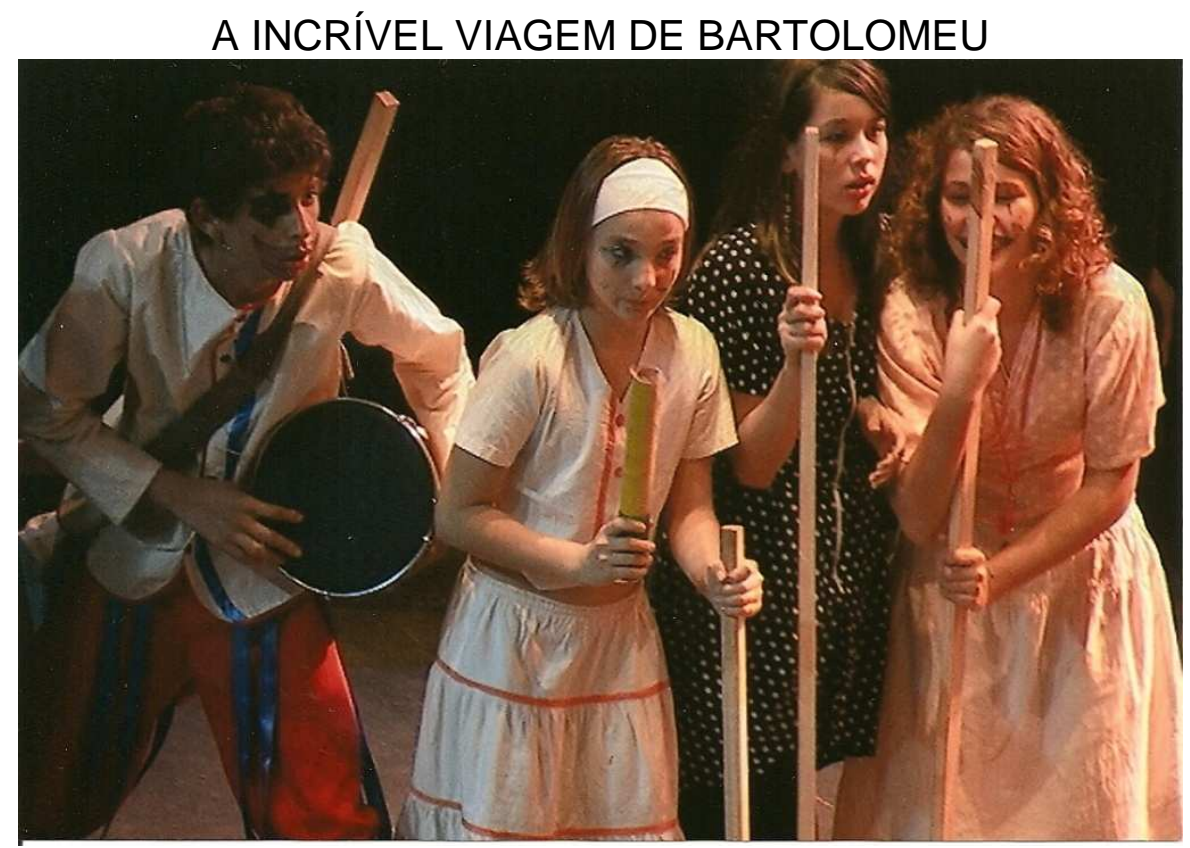

Autor: Sérgio Roberto e Thiago Leite

Grupo: Teatral Batalhão (DO)brado Júnior

Escola: Colégio Anglo Tatuí

Cidade Tatuí.

Do grupo Batalhão (DO)brado Júnior, participando pela segunda vez desse festival, traz um espetáculo desenvolvido a partir de jogos em sala de aula. O processo não tem pretensão nenhuma de se tornar um espetáculo, apenas foi dado um acabamento para se poder trazer ao palco, com direção do professor artista Tiago de Castro Leite. O público presente participou de uma deliciosa brincadeira de teatro. Durante o debate, a comissão julgadora questionou se o espetáculo devia ou não ser apresentado em um festival, uma reflexão que levanto é a de que o festival tem caráter estudantil. 


\section{RELEASE}

O enredo da peça se baseia na história do velho capitão Bartolomeu que sonhava em chegar a um novo lugar onde as pessoas pudessem viver de maneira mais justa e feliz. Mas para essa viagem o Capitão tem que enfrentar vários obstáculos, desde a descrença das pessoas de seu vilarejo até os terríveis mistérios do mar. Com uma trupe de alegres artistas, Bartolomeu se lança nesta aventura, em busca de uma terra de sonhos e felicidade.

O espetáculo que tem criação musical de Sérgio Roberto e Tiago Leite traz em sua encenação a alegria do brincar, a partir da experiência do jogo teatral. Com uma mistura de música, brincadeiras e a utilização de linguagens como o teatro de animação, convidamos o espectador a participar ativamente desta deliciosa "brincadeira".

Direção: Thiago de Castro Leite Assistência de Direção: Elton Pinheiro

Assistência técnica: João Armando Fabbro

Assistência de produção: Ariany Veloso e Priscila Cicari

Figurino: Vanuzia Cristina Queiroz

Marcos Felipe
Pereira Vieira
Leonardo Costa de
Camargo Barras
Fernando Henrique
Casaloura

\section{FICHA TÉCNICA E ARTÍSTICA}

Cenário: O Grupo

Maquiagem: O Grupo

lluminação: Thiago de

Castro Leite

Operadores de Luz:

Priscila Cicari e

Thiago Leite

Sonoplastia: Sérgio

Roberto e Thiago

Leite

Violão: Sérgio

Roberto

Flauta: Cristiane

Martins Berger

\section{ELENCO}

$\begin{array}{ll}\text { Jéssica de Almeida } & \text { Ângelo Stasievski } \\ \text { Serrão } & \text { Filho } \\ \text { Karoline Sales Bueno } & \text { Felipe Ribeiro } \\ \text { Lucas Barolo } & \text { Carolina Almeida de } \\ \text { Luís Otávio } & \text { Molon Mendes } \\ \text { Pâmela Stape } & \text { Larissa Stasievski } \\ \text { André Luiz Cardoso } & \text { Monique Mayumi }\end{array}$

Percurssão: Rafael

Jacó

Contra-regras: Ariany

Veloso dos Santos,

Camila Fonseca

Batista, Felipe de

Oliveira Festa, Raissa

Kirschner e Vinícius

Maciel Mendes

Pesquisa: Sérgio

Roberto Andrade e

Thiago de Castro

Leite.
Cardoso Yab
Yasmin Mayumi
Doy
Lucas Salzalli André Festa




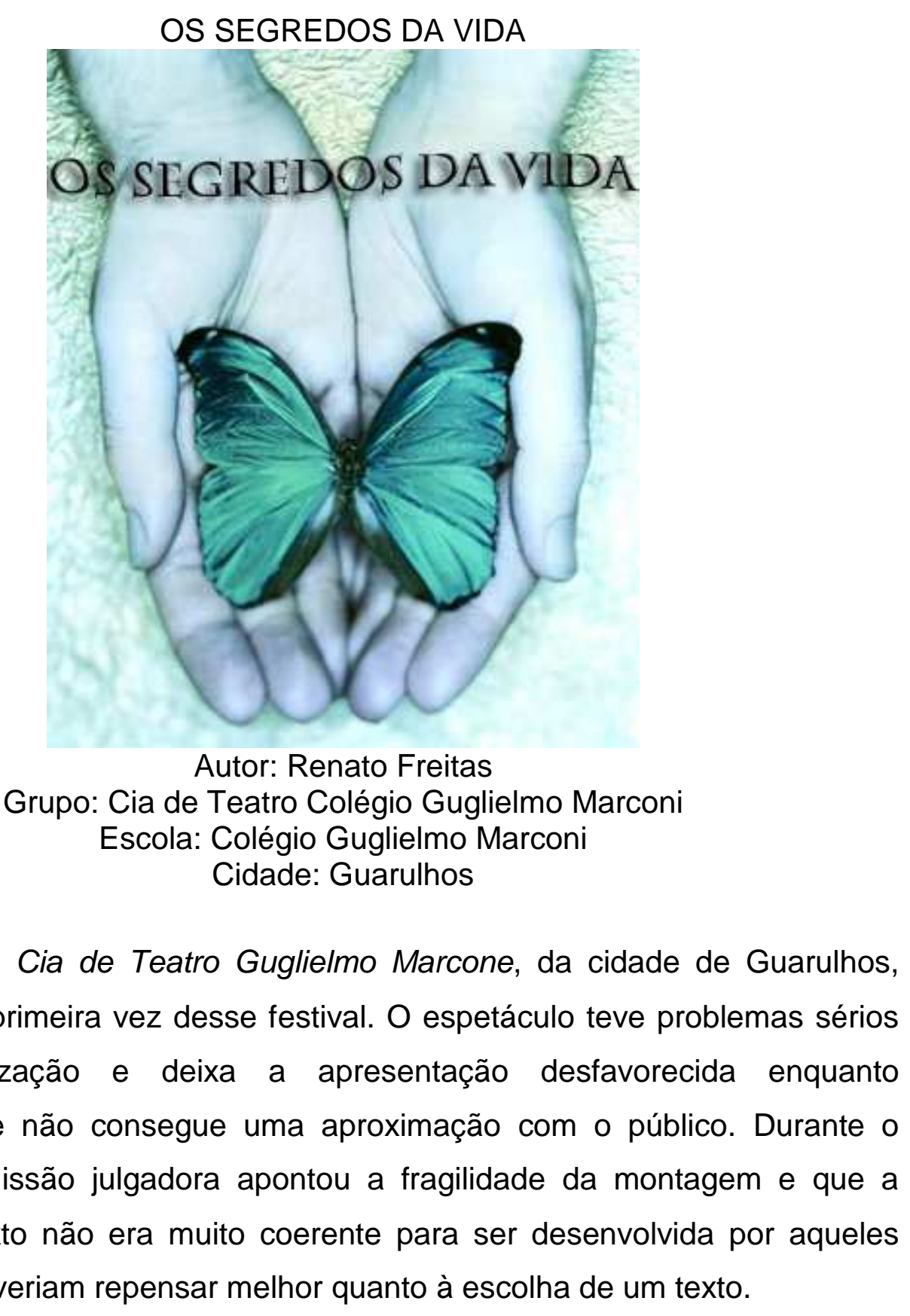


RELEASE

Beatriz, nos anos 1980, é cantora de um conceituado teatro e é forçada a escolher entre a vida de artista e o envolvimento com seu amado, desse relacionamento nasce Cristal. Após 20 anos, o sonho de Cristal é ser cantora famosa como Carol, atual cantora e dona de teatro.

Uma história de sonhos, objetivos e muitas surpresas encaminhadas pelo som do coração.

FICHA TÉCNICA E ARTÍSTICA

Direção: Renato Freitas e Marcelo Shmitt

Operador de Som: Ingrid Morales S. Bento

Operador de Luz: Rafael Ribeiro Batista.

ELENCO

$\begin{array}{lll}\text { Mariana Costa Eiacentini } & \text { Sarah Cristina Pacheco } & \text { Natália Lira Lima } \\ \text { Leonardo Raoni Oliveira } & \text { Oliveira } & \begin{array}{l}\text { Thatie Dragone Fabra } \\ \text { da Costa }\end{array} \\ \text { Brenda Villela de } & \text { Beatriz Santos } \\ \text { Jackeiine Levy Bastos } & \text { Vasconcellos Corrêa } & \text { Massini } \\ \text { Spuri } & \text { Camila Bezerra Silva } & \text { Jackeiine Otero } \\ \text { Mayara Rodrigues } & \text { Caroline Matos Martins } & \text { Zaporoli } \\ \text { Fernanda Marcella } & \text { Nathália Ardis Cândido } & \text { Mariane Lima da } \\ \text { Sandrine } & \text { Renato de Freitas } & \text { Costa } \\ \text { Carlos Alberto Fernandes } & \text { Barbosa } & \text { Thalita Cristine dos } \\ \text { Messias } & \text { Marcelo Shmitt } & \text { Santos } \\ \text { Vitor Vinjcius de Oliveira } & \text { Rodrigos Ramos Arruda } & \text { Márcia Mitiko Fujita } \\ \text { Fonseca } & \text { Nathália Isabel Aparecida } & \text { Andréa Cristina } \\ \text { Lilian de Souza Araújo } & \text { Xavier } & \text { Fava Pila } \\ \text { Renan de Andrade } & \text { Priscila Caroline Lopes } & \text { Tarini Coelho } \\ \text { Figueira } & \text { Cabral } & \text { Tamiris C de Moraes } \\ & & \end{array}$




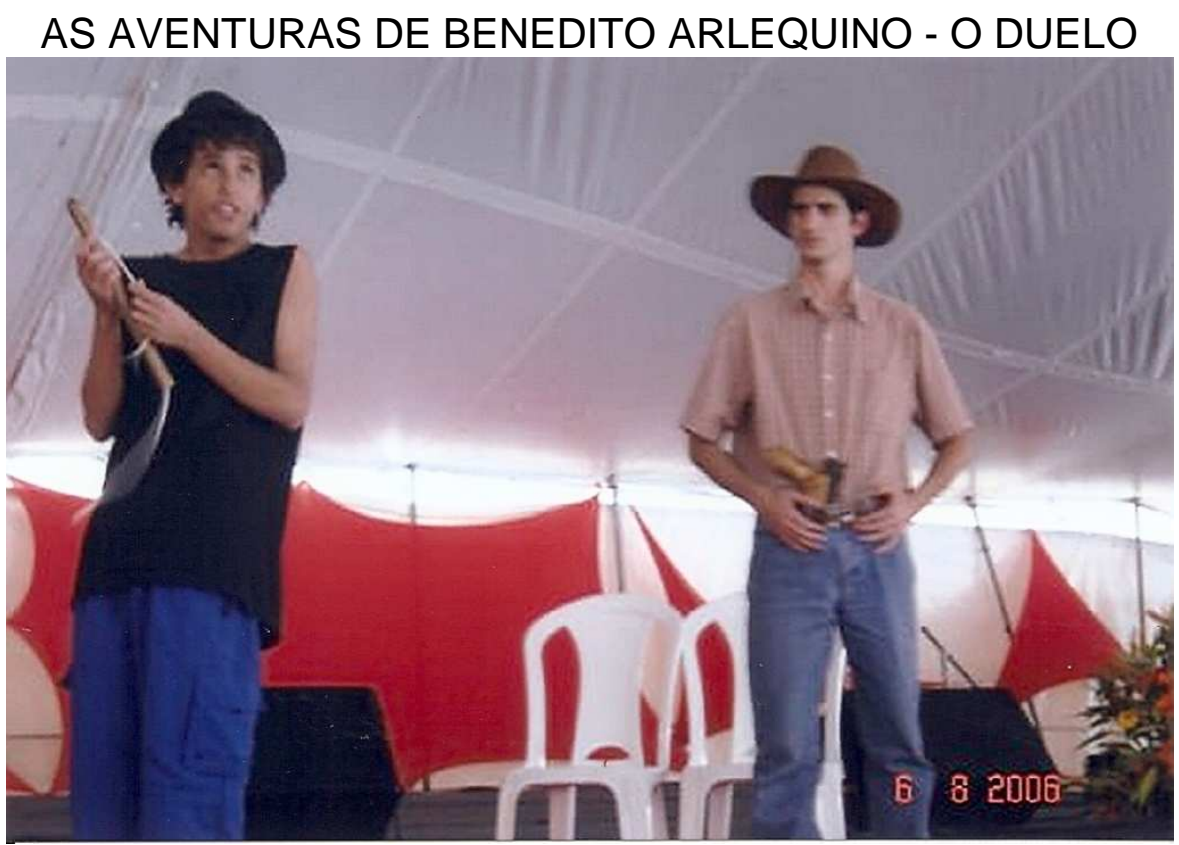

Adaptação Cia Pereirão de Teatro inspirada em $A$ pena e a lei, de Ariano

Suassuna

Grupo: Cia Pereirão de Teatro

Escola: E.E. Chico Pereira

Cidade:Tatuí.

Da Companhia Pereirão de Teatro, grupo que já participa desde a primeira edição do festival, com a direção do professor artista Tiago de Castro Leite, traz uma comédia para o palco que contagia de imediato o espectador. Um espetáculo simples e de bom gosto com uma iluminação criativa e uma cenografia enxuta. Durante o debate, a comissão julgadora elogia o processo de trabalho e aponta alguns textos para darem prosseguimento à linha de pesquisa que estão executando. 


\section{RELEASE}

Para conquistar o amor de Marieta, o esperto Benedito é capaz de fazer qualquer coisa, até mesmo enfrentar os dois valentões da cidade de Taperoá, que também se encontram apaixonados pela moça.

\section{FICHA TÉCNICA E ARTÍSTICA}

Direção: Thiago de Castro Leite

Coordenação: André Luis Camargo

Cenografia: O Grupo

Figurino: O Grupo

Maquiagem: Marília Teixeira e Jaqueline Cardoso

Iluminação: Thiago de Castro Leite

Operador de Luz: André Luis Camargo e Thiago de Castro Leite

Sonoplastia: O Grupo

\section{ELENCO}

Fernando Henrique Casalunga

Marília Teixeira

Jaqueline Cardoso

Éricke Sotero

Elton Pinheiro 
PREMIAÇÃO CATEGORIA INFANTIL

\begin{tabular}{|c|c|c|c|c|c|}
\hline & $\begin{array}{l}\text { TUCUNARÉ A } \\
\text { FILHA DA LUA }\end{array}$ & $\begin{array}{l}\text { A HISTÓRIA DE } \\
\text { FRUK }\end{array}$ & FEITIÇO DA VILA & $\begin{array}{c}\text { O FANTÁSTICO } \\
\text { MISTÉRIO DA } \\
\text { FEIURINHA }\end{array}$ & $\begin{array}{c}\text { A INCRIVEL } \\
\text { VIAGEM DE } \\
\text { BARTOLOMEU }\end{array}$ \\
\hline $\begin{array}{l}\text { ATOR } \\
\text { REVELAÇÃO }\end{array}$ & & & & $\begin{array}{c}\text { JHONNY } \\
\text { MEDEIROS }\end{array}$ & \\
\hline $\begin{array}{l}\text { ATRIZ } \\
\text { REVELAÇÃo }\end{array}$ & & & & $\begin{array}{c}\text { HAYA } \\
\text { MEDEIROS }\end{array}$ & \\
\hline $\begin{array}{l}\text { COADJUVANTE } \\
\text { MASCULINO }\end{array}$ & & $\begin{array}{l}\text { ALESSANDRO } \\
\text { MARCONI }\end{array}$ & & & \\
\hline $\begin{array}{l}\text { COADJUVANTE } \\
\text { FEMININO }\end{array}$ & & & & ANA DIAS & \\
\hline CENOGRAFIA & & TÂNIA BOY & & & \\
\hline ILUMINAÇÃO & FELIPE NÓRIS & & & & \\
\hline FIGURINO & & $\begin{array}{l}\text { MARIA } \\
\text { APARECIDA } \\
\text { RIBEIROE E } \\
\text { TÂNIA BOY }\end{array}$ & & & \\
\hline MAQUIAGEM & & & & & O GRUPO \\
\hline SONOPLASTIA & & & $\begin{array}{c}\text { QUINTETO } \\
\text { MUSICAL } \\
\text { "GARAGEM \& } \\
\text { CIA" }\end{array}$ & & \\
\hline DIREÇÃO & & TÂNIA BOY & & & \\
\hline MELHOR ATOR & & & & $\begin{array}{c}\text { RAFAEL } \\
\text { RODRIGUES }\end{array}$ & \\
\hline $\begin{array}{l}\text { AMELHOR } \\
\text { ATRIZ }\end{array}$ & & $\begin{array}{l}\text { ANA ELOISA } \\
\text { FONTES }\end{array}$ & & & \\
\hline $\begin{array}{l}\text { MELHOR ESPETÁACULO } \\
\text { JURI POPULAR }\end{array}$ & & & & $\begin{array}{c}\text { O FANTÁSTICO } \\
\text { MISTÉRIO DA } \\
\text { FEIURINHA }\end{array}$ & \\
\hline $\begin{array}{l}\text { MELHOR } \\
\text { ESPETÁCULO }\end{array}$ & & $\begin{array}{c}\text { A HISTÓRIA DE } \\
\text { FRUK }\end{array}$ & & & \\
\hline $\begin{array}{l}\text { 20 MELHOR } \\
\text { ESPETÁCULO }\end{array}$ & $\begin{array}{l}\text { TUCUNARÉ A } \\
\text { FILHA DA LUA }\end{array}$ & & & & \\
\hline
\end{tabular}


PREMIAÇÃo CATEGoRIa ADULTO

\begin{tabular}{|c|c|c|c|c|c|}
\hline & $\begin{array}{l}\text { GERAÇÃO } \\
\text { COCA-COLA }\end{array}$ & SHHH! & $\begin{array}{l}\text { A VIDA É } \\
\text { SONHO }\end{array}$ & $\begin{array}{l}\text { CORAÇÃO NA } \\
\text { BOCA }\end{array}$ & $\begin{array}{l}\text { OS SEGREDOS } \\
\text { DA VIDA }\end{array}$ \\
\hline $\begin{array}{l}\text { ATOR } \\
\text { REVELAÇÃo }\end{array}$ & & & & $\begin{array}{c}\text { ANDRÉ } \\
\text { FUREGATI }\end{array}$ & \\
\hline $\begin{array}{l}\text { ATRIZ } \\
\text { REVELAÇÃo }\end{array}$ & & & & $\begin{array}{l}\text { BÁRBARA } \\
\text { MOLNAS }\end{array}$ & \\
\hline $\begin{array}{l}\text { COADJUVANTE } \\
\text { MASCULINO }\end{array}$ & & & & $\begin{array}{l}\text { RÔMULO } \\
\text { PONTES }\end{array}$ & \\
\hline $\begin{array}{l}\text { COADJUVANTE } \\
\text { FEMININO }\end{array}$ & & & & PAULA TAVARES & \\
\hline CENOGRAFIA & & & $\begin{array}{c}\text { KELVIS } \\
\text { GERMANO }\end{array}$ & & \\
\hline ILUMINAÇÃO & $\begin{array}{c}\text { ERIKA } \\
\text { BODSTEIN }\end{array}$ & & & & \\
\hline FIGURINO & $\begin{array}{l}\text { VALÉRIA } \\
\text { MARCHI }\end{array}$ & & & & \\
\hline MAQUIAGEM & & & GRUPO & & \\
\hline SONOPLASTIA & $\begin{array}{c}\text { ERIKA } \\
\text { BODSTEIN }\end{array}$ & & & & \\
\hline DIREÇÃO & & & & $\begin{array}{c}\text { VALÉRIA } \\
\text { MARCHI E ÉRIKA } \\
\text { BODSTEIN }\end{array}$ & \\
\hline MELHOR ATOR & & & & IRATÂ CAMPOS & \\
\hline MELHOR ATRIZ & & & & $\begin{array}{l}\text { MARINA } \\
\text { MACHADO }\end{array}$ & \\
\hline $\begin{array}{l}\text { MELHOR ESPETÁCULO } \\
\text { JURI POPULAR }\end{array}$ & & & & $\begin{array}{c}\text { CORAÇÃO NA } \\
\text { BOCA }\end{array}$ & \\
\hline $\begin{array}{l}\text { MELHOR } \\
\text { ESPETÁCULO }\end{array}$ & & & & $\begin{array}{c}\text { CORAÇÃO NA } \\
\text { BOCA }\end{array}$ & \\
\hline $\begin{array}{l}\text { 20 MELHOR } \\
\text { ESPETÁCULO }\end{array}$ & $\begin{array}{l}\text { GERAÇÃO } \\
\text { COCA-COLA }\end{array}$ & & & & \\
\hline
\end{tabular}




\begin{tabular}{|c|c|c|c|c|c|}
\hline & $\begin{array}{l}\text { PÓLIS DE } \\
\text { POLENICE }\end{array}$ & $\begin{array}{l}\text { A TÁVULA } \\
\text { REDONDA }\end{array}$ & 5 POR VINTE 5 & $\begin{array}{c}\text { ARENA CONTRA } \\
\text { ZUMBI }\end{array}$ & $\begin{array}{l}\text { AS AVENTURAS DE } \\
\text { BENEDITO } \\
\text { ARLEUIIO- } \\
\text { DUELOO }\end{array}$ \\
\hline $\begin{array}{l}\text { ATOR } \\
\text { REVELAÇÃo }\end{array}$ & & & & & $\begin{array}{l}\text { FERNANDO } \\
\text { HENRIQUE } \\
\text { CASALUNGA }\end{array}$ \\
\hline $\begin{array}{l}\text { ATRIZ } \\
\text { REVELAÇÃo }\end{array}$ & & $\begin{array}{l}\text { HELOIISA } \\
\text { ALVARES }\end{array}$ & & & \\
\hline $\begin{array}{l}\text { COADJUVANTE } \\
\text { MASCULINO }\end{array}$ & PEDRO FONTES & & & & \\
\hline $\begin{array}{l}\text { COADJUVANTE } \\
\text { FEMININO }\end{array}$ & & LÍGIA HELENA & & & \\
\hline CENOGRAFIA & O GRUPO & & & & \\
\hline ILUMINAÇÃO & ALEIXO BILLY & & & & \\
\hline FIGURINO & & $\begin{array}{l}\text { RENATA } \\
\text { SOAREZ }\end{array}$ & & & \\
\hline MAQUIAGEM & & & & & $\begin{array}{c}\text { MARIILIA } \\
\text { TEIXEIRA E } \\
\text { JAQUELINE } \\
\text { CARDOSO }\end{array}$ \\
\hline SONOPLASTIA & & MAX FRANÇOIS & & & \\
\hline $\begin{array}{l}\text { MELHOR } \\
\text { COREOGRAFIA }\end{array}$ & & & & & \\
\hline DIREÇÃO & & & & $\begin{array}{l}\text { VALÉRIA DE } \\
\text { OLIVEIRA }\end{array}$ & \\
\hline MELHOR ATOR & CARLOS DOLES & & & & \\
\hline MELHOR ATRIZ & & MARIANA GULIN & & & \\
\hline $\begin{array}{l}\text { MELHOR ESPETÁCULO } \\
\text { JURI POPULAR }\end{array}$ & & & & $\begin{array}{c}\text { ARENA CONTRA } \\
\text { ZUMBI }\end{array}$ & \\
\hline $\begin{array}{l}\text { MELHOR } \\
\text { ESPETÁCULO }\end{array}$ & & & & $\begin{array}{c}\text { ARENA CONTRA } \\
\text { ZUMBI }\end{array}$ & \\
\hline $\begin{array}{l}2^{\circ} \text { MELHOR } \\
\text { ESPETÁCULO }\end{array}$ & $\begin{array}{l}\text { PÓLIS DE } \\
\text { POLENICE }\end{array}$ & & & & \\
\hline
\end{tabular}




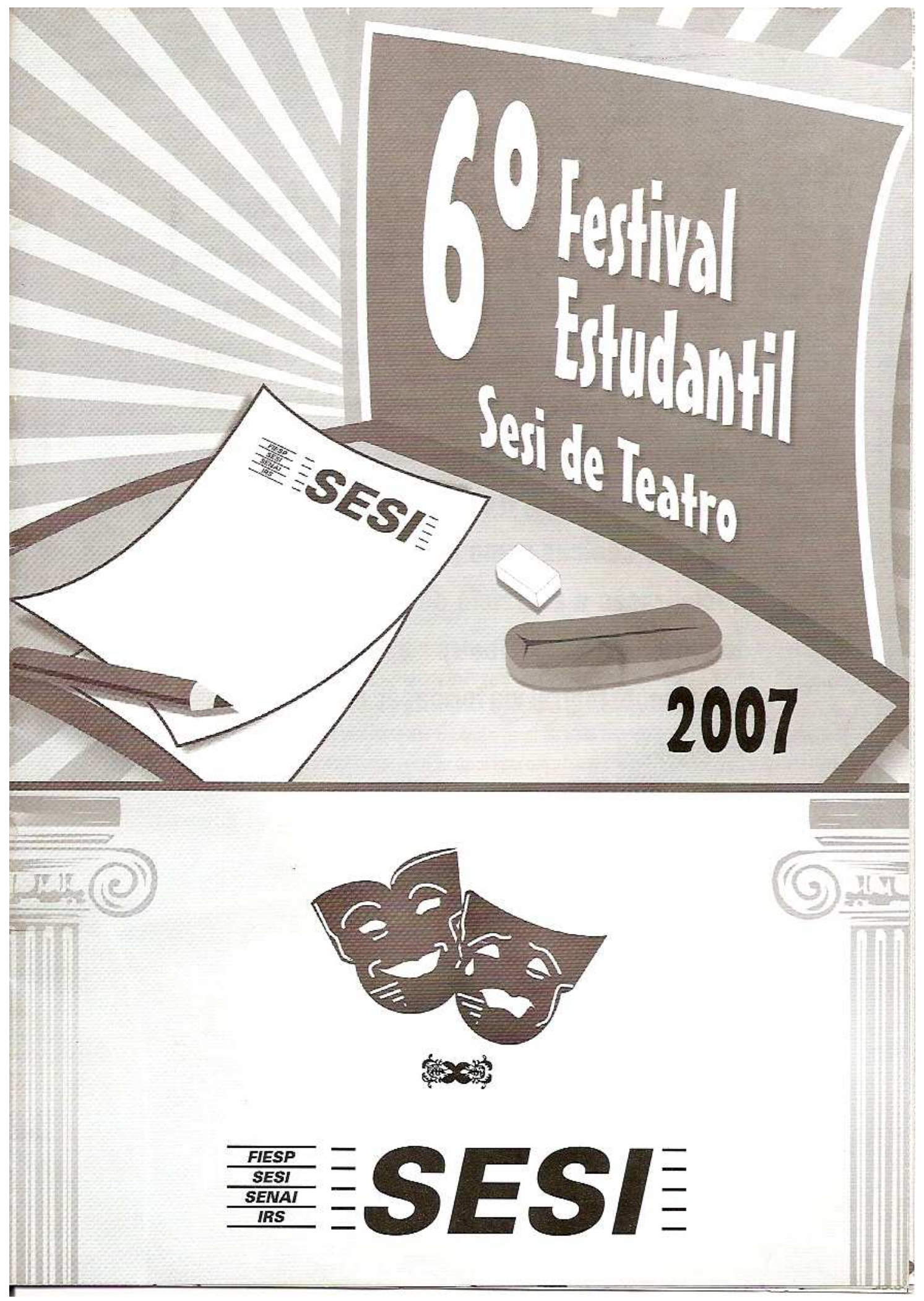




\section{Festival Estudantil SESI de Teatro 2007}

O 6o Festival Estudantil acontece com as três categorias "Teatro para Criança"; "Teatro Adulto" e "Categoria Livre" como foram formatados para edição anterior. Tendo como jurados Clauidia Dalla Verde, Karin Mellone e Clóvis Garcia e curadoria da Profa. Dra. Ingrid Dormien Koldela .A crescente desenvoltura dos grupos é perceptiva. Nesse ano não colocamos as mesas de reflexão por decisão conjunta com os grupos participantes que, ao longo do ano, fizeram encontros para ajudar a tomar diretrizes do festival. No tocante à premiação, foi decidido ser mantida, para que os grupos tenham uma maior valorização dentro das escolas. Talvez o prêmio dê uma legitimidade ao trabalho desenvolvido. Durante todo festival, foram apontados aspectos positivos. Os debates que eram coordenados pela professora Ingrid Koudela, ao contrário de edições anteriores, ganharam uma nova característica de orientação aos grupos. Nesse novo formato de debate, os grupos conseguiam entender de maneira mais clara o posicionamento da comissão julgadora.

Um fato curioso que gostaria de ressaltar é que durante essa edição uma auditoria externa se realizava no Sesi local e muitas explicações tiveram que ser dadas, como por exemplo, das pessoas alojadas, o porquê de tantas filas e de tantas alimentações. Tive que justificar um a um dos alojados, mas mesmo assim a auditoria se mostrou desfavorável ao evento. 


\section{UMA LENDA DA AMAZÔNIA}

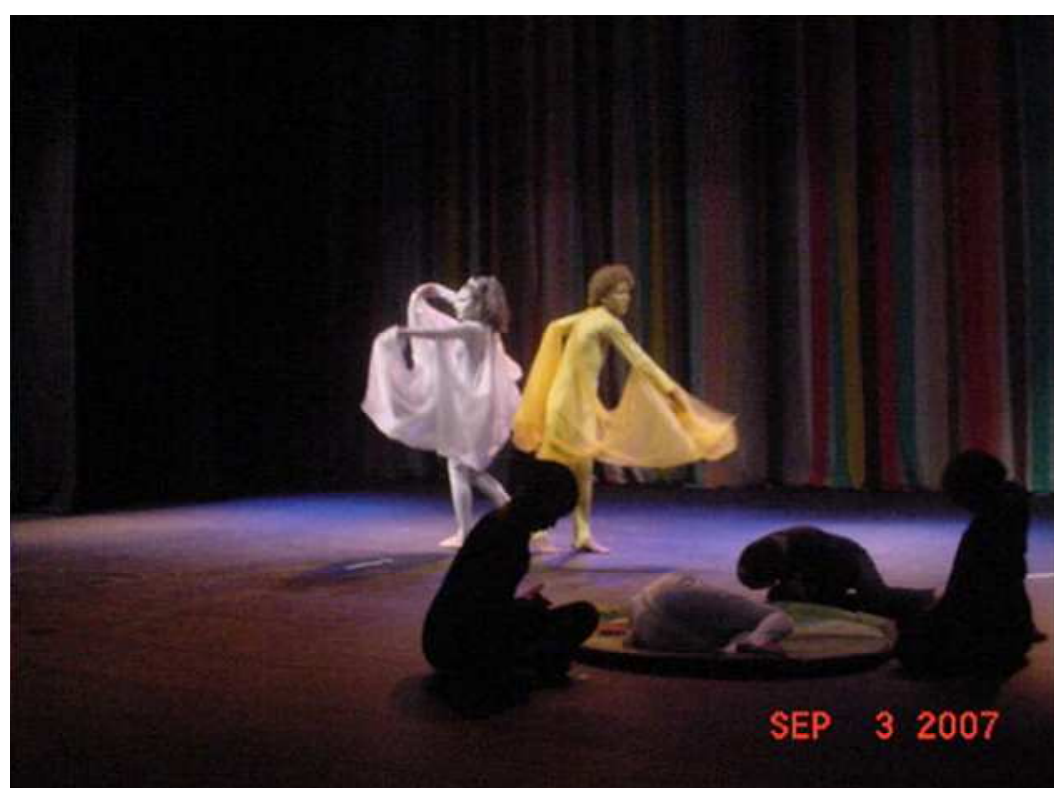

Adaptação da Peça "Tucunaré - a filha da Lua" de Ronaldo Ciambroni Grupo: Cia de Teatro UTA Escola: E.E. Afonso Vergueiro Cidade: Salto de Pirapora

Com direção da professora artista Jane Kastrorsky, o espetáculo vem maduro e com grande pesquisa. $O$ trabalho dos jogos é evidente entre os atores. O espetáculo prima pelo figurino e maquiagem; a professora artista participa pela sexta vez desse festival e em decorrência de sua trajetória pelo festival o amadurecimento do grupo e todo trabalho tem um ganho surpreendente. Durante o debate, a comissão julgadora ressaltou os mesmos pontos aqui já citados. 


\section{RELEASE}

Adaptação da peça Tucunaré - a filha da Lua, de Ronaldo Ciambroni, é uma lenda indígena que conta a história do namoro do Sol com a Lua e desse amor nasceu uma menina. A princípio, ela era uma bola de luz que foi depositada numa gigante vitória-régia do rio Amazonas para que protegesse a mata, a Floresta Amazônica. Tucunaré foi criada pela tribo do índios Tucunas e transformou-se, então, na guerreira defensora da mata, símbolo da ecologia. Como proposta de encenação, a direção buscou a utilização de signos recorrentes durante o espetáculo e o emprego de planos, dentro da caixa preta. Desta vez um texto para crianças foi escolhido na tentativa de trabalho com diferentes estilos, linguagens. A estética retratada não pretende recriar literalmente os costumes e os padrões da tribo dos Tucunas, nem na floresta Amazônica, mas sim produzir um Universo de representação e amostragem das situações vividas pelas personagens.

Direção: Jane Kastorsky

Maquiagem: Marcelo Bernini

Cabelo e Relações Públicas: Rode

Barrabella

Sonoplastia: Marco Aurélio e

Rosângela

Iluminação, operador de luz e

filmagem: Felipe Nóris
FICHA TÉCNICA E ARTÍSTICA

Figurino: Jane Kastorsky e Angélica Leme Confecção do Figurino: Áurea Ap. de Almeida

Cenografia: Dorival de

Souza/Fotografia: A. Tozze

Preparação física: Sueli Anhaia

Preparação Corporal e Coreografia: Mídia Lopez

\section{Eliza Santana Évelin Ferraz \\ Kelly Dias \\ Leandro de Freitas \\ Mariana Avanzzi \\ Reinaldo Cruz}

\section{ELENCO}

Zeca Campos

Eliézer Santos

Natália Souza

Thiago Gouveia

Kamila Kleve

Bruna Carvalho
Paola Santos

Daniellen Almeida

Soraya Jasmineiro

João Belchior 


\section{AS AVENTURAS DE PETER E WENDY NA TERRA DO NUNCA}

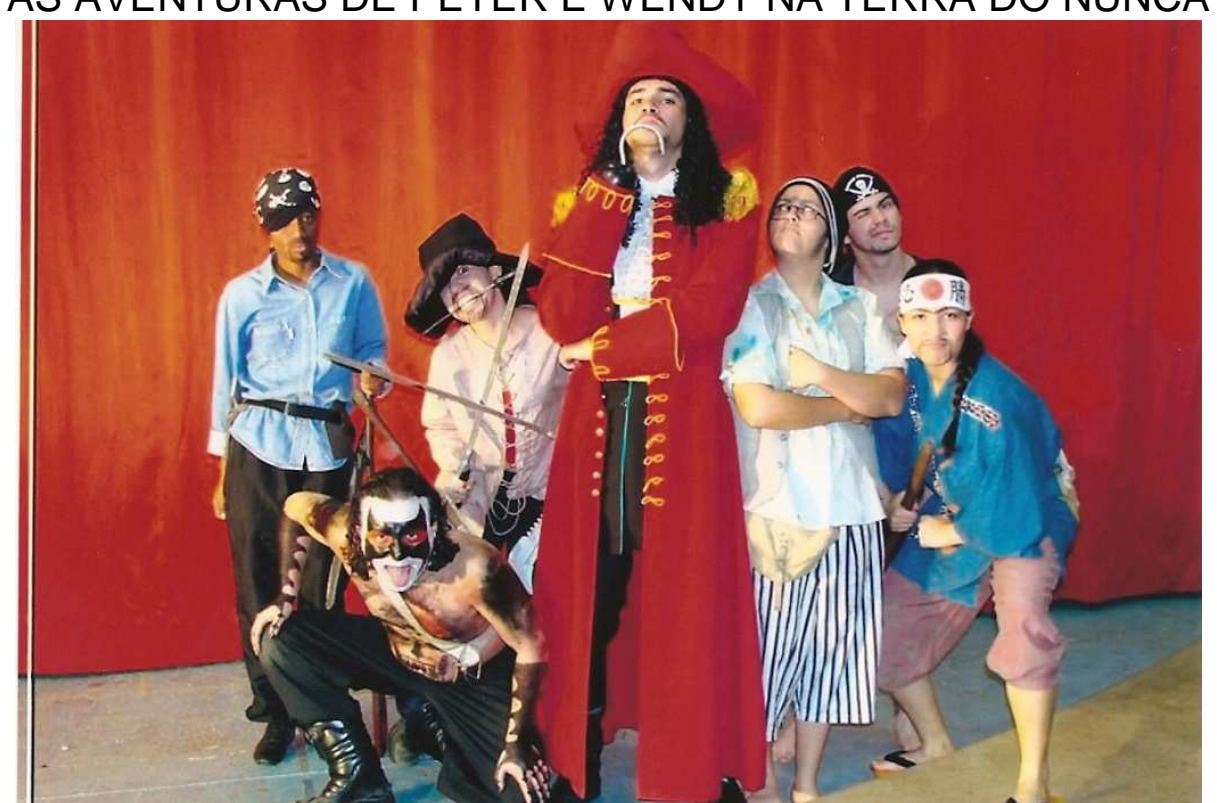

Autor: Texto coletivo baseado na obra de Sir James Barrie Grupo: Grupo Teatral Tapanaraca Mutatis Mutandis

Escola: E.E. Peixoto Gomide

Cidade: Itapetininga

O grupo, com direção do professor artista Fábio Jurera, surpreende com o espetáculo, encanta o público com uma performance com grandes achados da direção; com uma cenografia que nos transporta para o mundo da Terra do Nunca e o crescimento do grupo é visível nessa terceira participação no festival. Os atores interpretam de uma maneira que chega a emocionar pelo domínio de suas ações. Durante o debate, a comissão julgadora coloca 0 crescimento do grupo e o Professor Clóvis Garcia fala muito sobre o desempenho da cenografia. 


\section{RELEASE}

Tudo corre bem na casa da família Darling, até que Wendy recebe a triste notícia de que não poderá mais dormir no mesmo quarto que seus irmãos. Depois da saída dos pais para um jantar, Wendy coloca seus irmãos na cama e recebe a visita inesperada de um jovem menino que aparece procurando pela sua sombra que havia descolado na noite anterior. O jovem rapaz é nada mais nada menos que o herói de suas histórias, Peter Pan. Peter propõe a Wendy que vá com ele para a Terra do Nunca. Depois de pensar um pouco, aceita o convite com a condição de poder levar seus outros dois irmãos, João e Miguel. Com a proposta aceita, os três irmãos se vêem em aventuras nunca antes imaginadas. Um espetáculo que leva o público para o mundo de magia e brincadeiras, onde tudo é possível.

Direção: Fábio Jurera

\section{FICHA TÉCNICA E ARTÍSTICA}

Iluminação: Lucy Villar

Sonoplastia: Fãbio Jurera

Maquiagem: grupo

Figurino: Grupo

Cenário: grupo

Contra-regras: Sandra Rogério, Anderson Thiago e Marcos Felipe.

Ana Dias

Daniele Ayres

Diego Pereira

Elis Regina

WW Gomes

\section{ELENCO}

Jhonny Medeiros

Haya Medeiros

Kássia Ayumi

Arthur Ferarezi

Antônio Panis
Camila Nalesso

Andréa Vaz

Felipe Almeida

Juliana Rodrigues

Rafael Rodrigues 


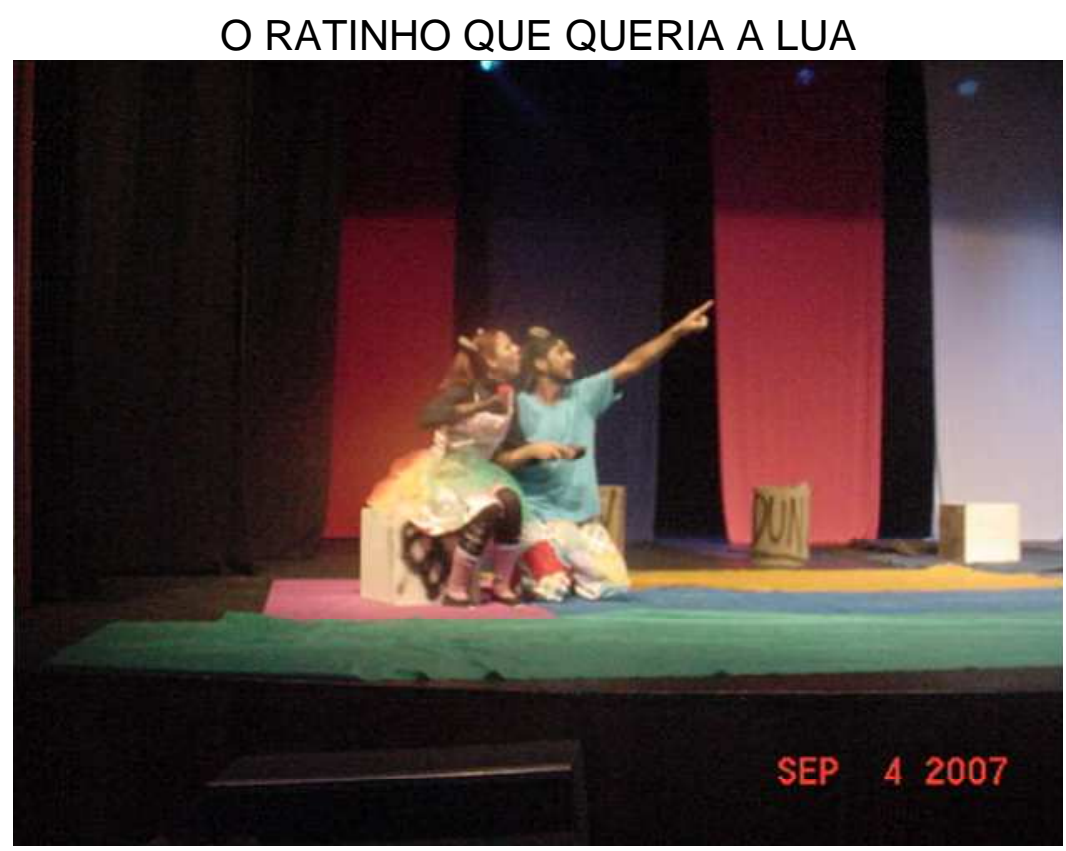

Autor: Patrícia Nepumoceno

Grupo: Cia de Teatro Uni-Duni-Tê

Escola: EMEF Prof. Dr. Paulo Gomes Cardin

Cidade: São Paulo

O espetáculo para criança, dirigido pelo professor artista José Wagner não consegue uma boa realização, com problemas de cenografia segue arrastado e não consegue encantar as crianças, mesmo com todo apelo do figurino. Durante o debate, a comissão julgadora ressalta esses pontos e faz uma reflexão, considerando que o grupo levasse em conta a importância de se fazer teatro para a criança. 


\section{RELEASE}

O centro da história é Egídio, um ratinho esperto, que acredita que a lua é um imenso Queijo. Uma noite ao ver a Lua minguante, Egídio tem a certeza de que ela é um queijo e que um rato chegou até ela e comeu a metade. A partir daí, Egídio tenta criar uma forma para alcançar a Lua, tendo ajuda da meiga e doce Anabela. Quando Egídio percebe que sua missão e seu desejo são impossíveis de ser alcançado, Anabela recebe a visita de sua rata madrinha que, após um pedido, realiza o desejo de Egídio e o desejo secreto de Anabela.

Direção: José Wagner

\section{FICHA TÉCNICA E ARTÍSTICA}

Iluminação: José Wagner

Sonoplastia: José Wagner

Cenários: José Wagner

Figurinos: Patrícia Nepomuceno

Coreografia: Aline Fernandes

Trilha Sonora: Patrícia Nepomuceno e Aline Fernandes

Maquiagem: O grupo

Contra regras: Rafael Batista, Cecília Corelli, Jéssica Souza e Adonai Bezerra

Renato Ribeiro

\section{ELENCO}

Patrícia Nepomuceno

Juliana Batista

Aline Fernandes 


\section{O SALVAMENTO DA PALMEIRA}

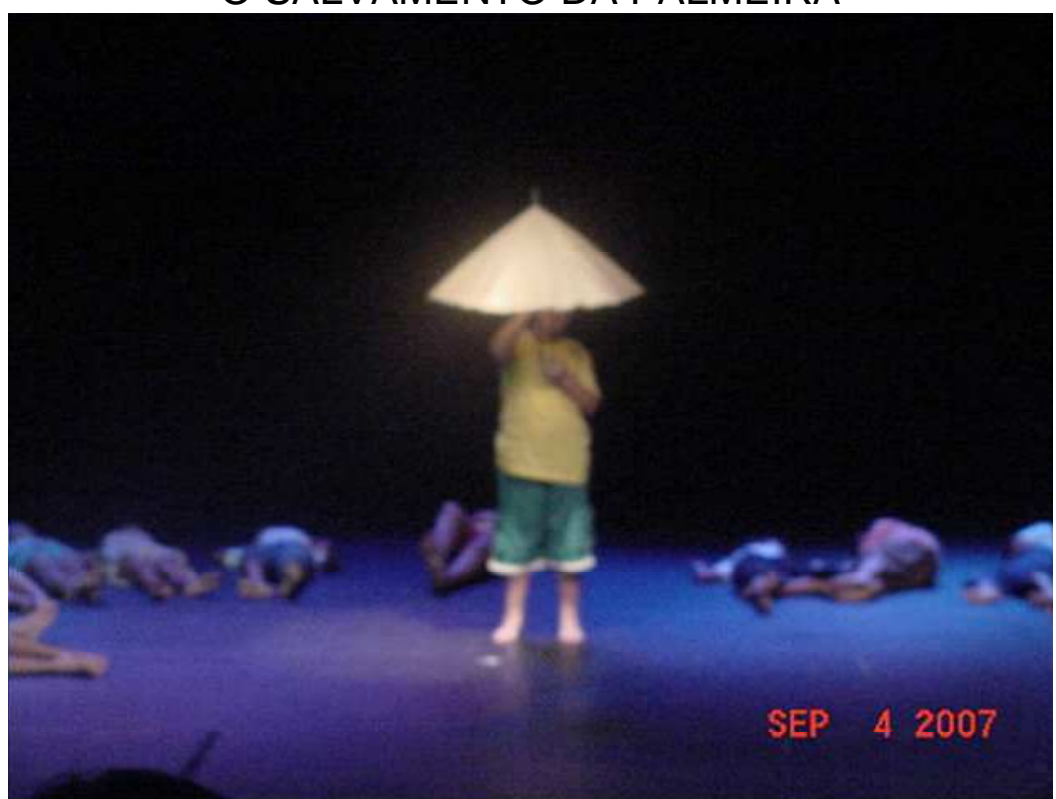

Autor: Thiago Leite

Grupo: A Trupe Cata Vento

Escola: Colégio Anglo

Cidade: Boituva

O professor artista Tiago Leite trouxe pela primeira vez esse grupo para participar do festival. O espetáculo Salvamento da Palmeira trouxe para o palco o processo vivenciado pelos seus alunos em sala de aula. A partir de brincadeiras de roda, os alunos atores formados por crianças, de sete a nove anos, deliciavam-se com o que estavam fazendo e automaticamente a platéia que, também, na maior parte era constituída por crianças se deliciava com aquele momento lúdico. Acredito muito nessa questão, que o professor artista trouxe nesse espetáculo, talvez tenhamos que ter olhos mais atentos para esses processos. Durante o debate, a comissão julgadora estabelece que talvez o espetáculo deva ir para um espaço mais alternativo, ao invés de um palco italiano. 


\section{RELEASE}

A partir de brincadeiras de roda, um grupo de crianças conta a história de uma majestosa palmeira que murcha. Assim, vão em busca de uma solução para salvar um símbolo de sua imaginação. Enfrentando alguns obstáculos, aventuram-se em busca da água sagrada, a qual, segundo Vó Dita, uma velha muito sábia, salvará a grande árvore. O salvamento da Palmeira trata-se de um trabalho lúdico em que o jogo teatral e as brincadeiras de roda são os estímulos principais para a criação teatral. A partir destes elementos, surgem imagens de uma beleza e uma pureza inquebrantáveis, proporcionando ao público, uma maravilhosa troca com o universo da criança.

\section{FICHA TÉCNICA E ARTÍSTICA}

Direção: Thiago de Castro Leite Sonoplastia: Thiago Leite Violão: Vitor Oliveira Netto Cenografia: Trupe Cata-vento Iluminação: Thiago Leite Operação de Luz: Laura Baggio Contra-regragem: André Luis Camargo, Alex Dias Alves, Beatriz Gomes Garcia, Glória Ventura,
Erivelton Oliveira Lima, Marie

Terashima Yoshizawa, Osvaldo

Ferreira, Mônica Magnano e Sandra Almeida Coordenação Pedagógica: Giovana Gomes Diretora do Colégio: Maria Ângela Leis

\section{ELENCO}

Ana Virgínia Scaglione Antônio Rodrigues Ferreira Anyara Paula Leite Bruna da Rocha Clariana Roncati Emily Mills Gabriela Aquino
Gabriella Fabri Chagas Geovanna Meirelles Heitor Giovani Igor Augusto Barbosa Igor Fernandes F. de Lima João Pedro Veduvoto José Henrique Provasi
Laura Campos Santos

Leticia Siqueira

Letícia Yumi

Luana V. Bento

Saul de Campos

Vanessa Fernanda

Brancaccio. 


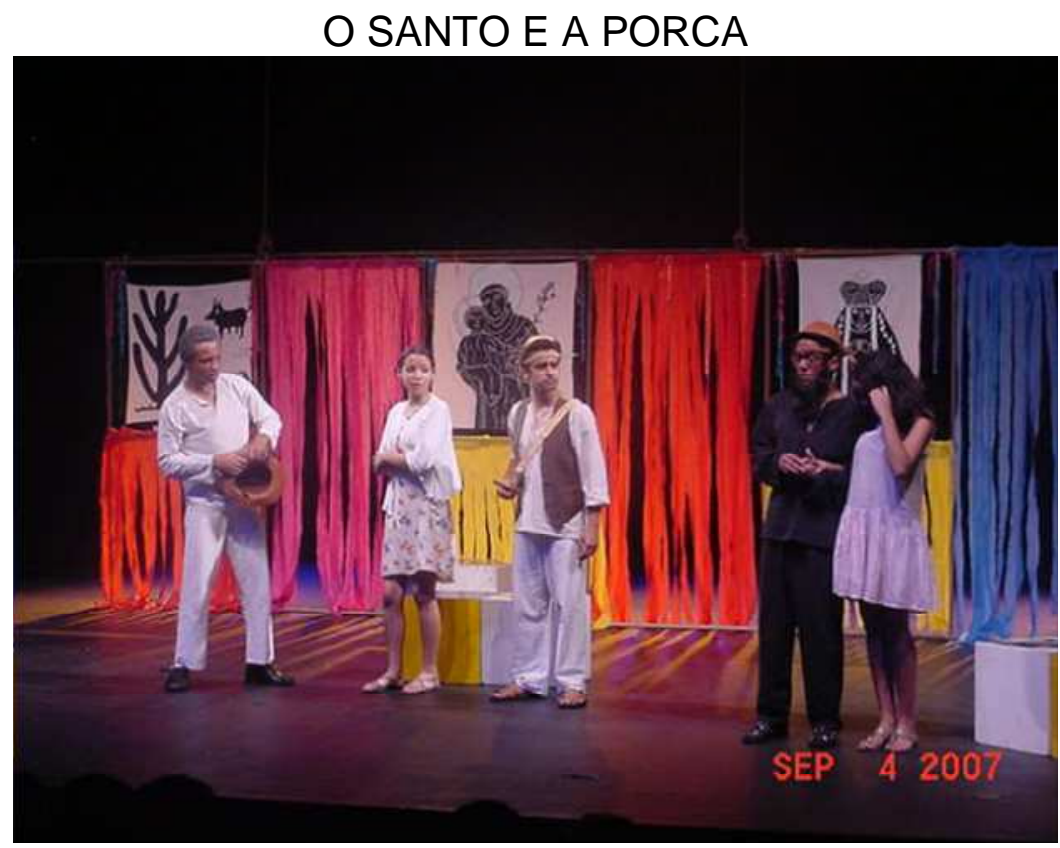

Autor: Ariano Suassuna

Grupo: UNI-DUNI-TÊ

Escola: EMEF Prof. Dr. Paulo Gomes Cardim

Cidade: São Paulo

O espetáculo, dirigido pelo professor artista José Wagner e Patrícia Nepomuceno, não teve uma pesquisa muito clara e o desacordo do texto com o autor Ariano Suassuna era totalmente presente, as personagens estavam equivocadas em sua construção. O espetáculo não aconteceu, a cenografia chegou a atrapalhar mais ainda. Não se sabia ao certo que caminho o espetáculo queria tomar se era comedia del'arte, realista ou bufão. Durante o debate, a comissão julgadora fez altas críticas no sentido de orientá-los, pois os equívocos eram muito evidentes. 


\section{RELEASE}

O centro da história é Eurico Árabe, um velho avarento, devoto de Santo Antônio, assombrado pela idéia de que todos querem roubá-lo. Por isso, guarda em sua casa uma porca de madeira, presente de seu avô, onde esconde dinheiro durante anos e anos. Tantos anos, que o dinheiro perde 0 valor. Ao redor de Eurico estão: a filha Margarida, a irmã solteirona Benona, um fazendeiro rico e viúvo, Eudoro, o filho do fazendeiro, Dodô, disfarçado de corcunda, e dois criados - Caroba e Pinhão. Entre confusões, encontros e desencontros, formam-se, enfim, três casais apaixonados - e sobra um velho sovina com sua porca e seu santo.

\section{FICHA TÉCNICA E ARTÍSTICA}

Direção: José Wagner e Patrícia Nepomuceno

Iluminação: José Wagner

Sonoplastia: Patrícia Nepomuceno

Cenários: José Wagner

Figurinos: Patrícia Nepomuceno

Coreografia: Aline Fernandes

Trilha Sonora: Patrícia Nepomuceno e Aline Fernandes

Maquiagem: O Grupo

Contra Regras: Rafael Batista, Cecília Corelli, Jéssica Souza e Roberto

Quirino.

Ivan da Silva Renato Ribeiro Adonai Bezerra
ELENCO

Jones Marinho Thamires Marques

Aline Fernandes
Alessandra Gyanei 


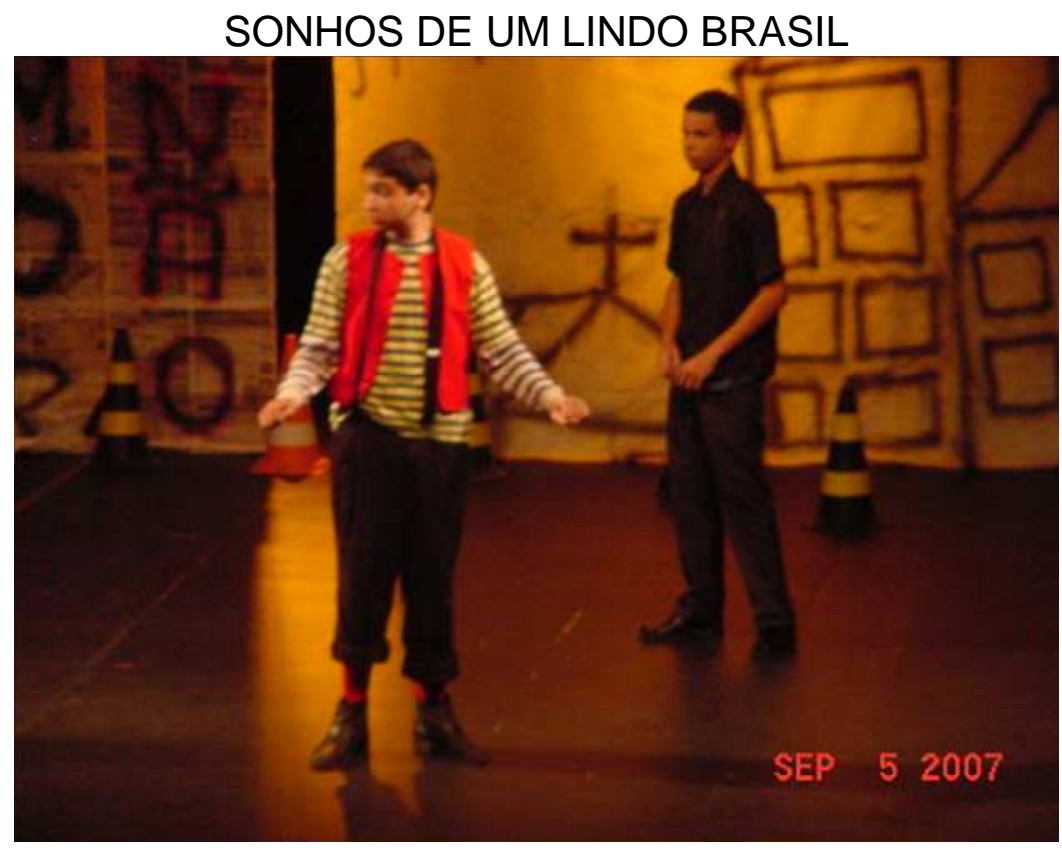

\section{Texto: O Grupo \\ Grupo: 3 num Barco Só}

Escola: E.E. Ezequiel Machado Nascimento

Cidade: Sorocaba

O espetáculo, de direção de Vitor Gabriel, que também integra o elenco, participa pela primeira vez do festival, trouxe uma realidade vivenciada pelos alunos. O espetáculo formado dentro da escola apenas com alunos sem a intervenção de nenhum profissional para orientá-los, mas mesmo assim o espetáculo aconteceu, pois era evidente a energia e a vontade do fazer teatral que se estabelecia entre os três atores. A comissão julgadora indicou caminhos para orientá-los em suas próximas montagens. 


\section{RELEASE}

Com o intuito de mostrar as verdades de nosso país, três narradores vêm até o palco contar várias histórias de diversos personagens, mostrando as suas desgraças do cotidiano, em situações hilariantes. Abordando um tema atual, passam pelo palco, diversas personalidades, dentre eles, Ernesto, um cearense que veio da sua terra natal para tentar a vida na capital e que acaba tendo que fazer diversos trabalhos para sobreviver, assim como uma dona de casa a beira de um ataque de nervos, entre outros.

\section{FICHA TÉCNICA E ARTÍSTICA}

Coordenadora: Vera Lúcia Vieira

Vitor Gabriel

\section{ELENCO}

Daniela Silva de Qwuadros

Felipe Aruda Rodrigues 


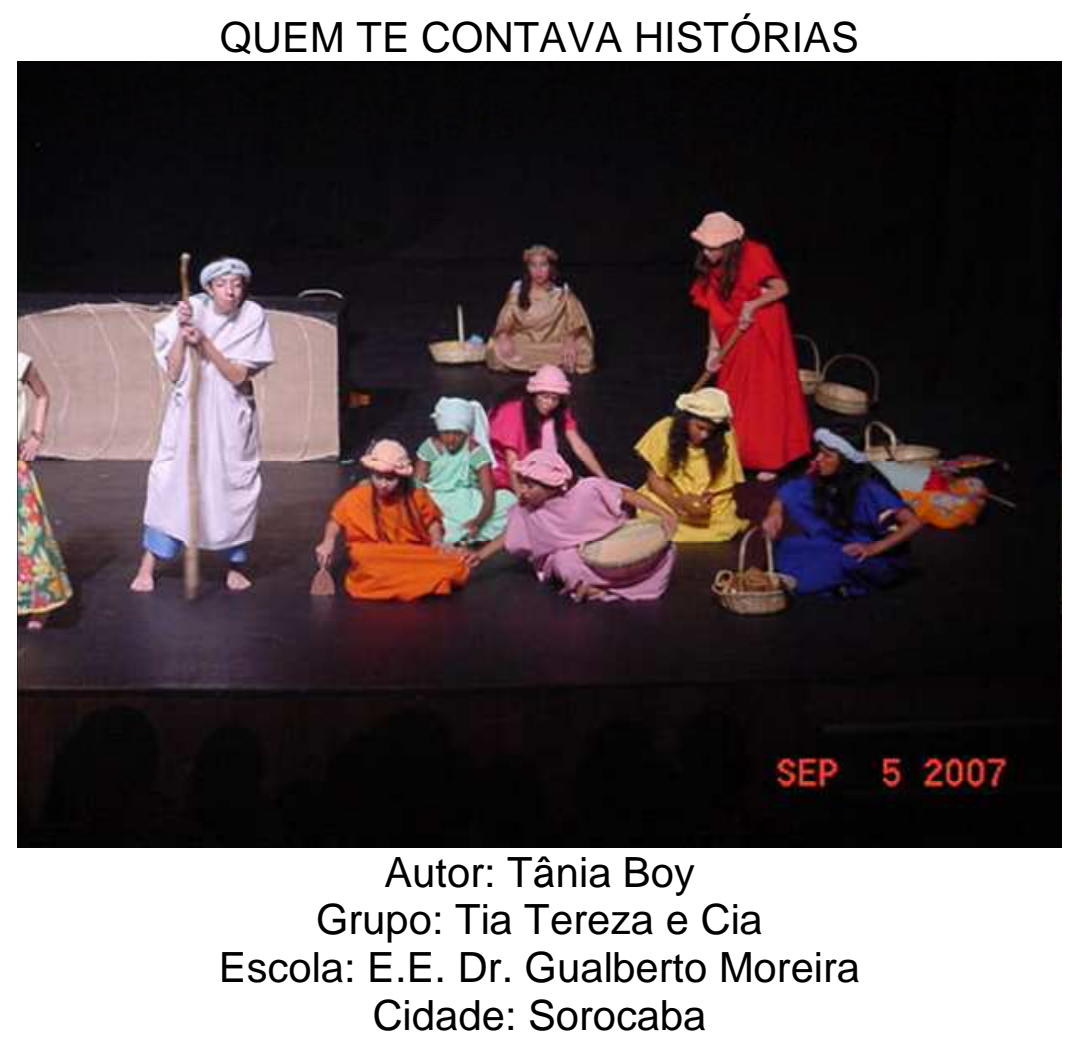

De autoria e direção da professora artista Tânia Boy, o espetáculo nos faz viajar através das músicas e danças, simples sem grandes efeitos, mas um teatro feito por crianças para crianças de maneira que a identificação foi imediata e a interação era visível. As atrizes, todas descalças, davam um toque de maior referência à cultura que o grupo ali resgatava. Durante o debate, foi ressaltada a pesquisa e o processo de trabalho do grupo e principalmente o da professora artista. 


\section{RELEASE}

O espetáculo é uma comédia musical que relata a história dos integrantes do grupo, e também conta histórias de lendas africanas. A peça tem por objetivo resgatar um pouco dessa cultura apresentando músicas, danças e lendas.

\section{FICHA TÉCNICA E ARTÍSTICA}

Direção: Tânia Boy Co-direção: Camila Rocha Iluminação: Tânia Boy Sonoplastia: Tânia Boy Cenografia: Tânia Boy e Camila Rocha Figurino: Maria Ap. e Tânia Boy Coreografia e preparação corporal: Sheila Guidem

Monique Novaes Amanda Engle Amanda Marconi Bruna Couto Alessandro Marconi Mickaely Mota Nadine Marca Ágata Galdino Jéssica Madeiros
Capoeira e Maculelê: Arlindo e Camila Rocha Maquiagem: Camila Rocha Operação de Som: Camila Rocha Operação de luz: Tânia Boy Contra regra: Marisa Campos, Felipe Rocha e Diego Kenit

ELENCO

Lourdinha Santos

Nadia Gallio

Pámela Silva

Driely Ferreira

Diana Ramos

Bianca Farias

Nathália Correa

Pámela Ribeiro 


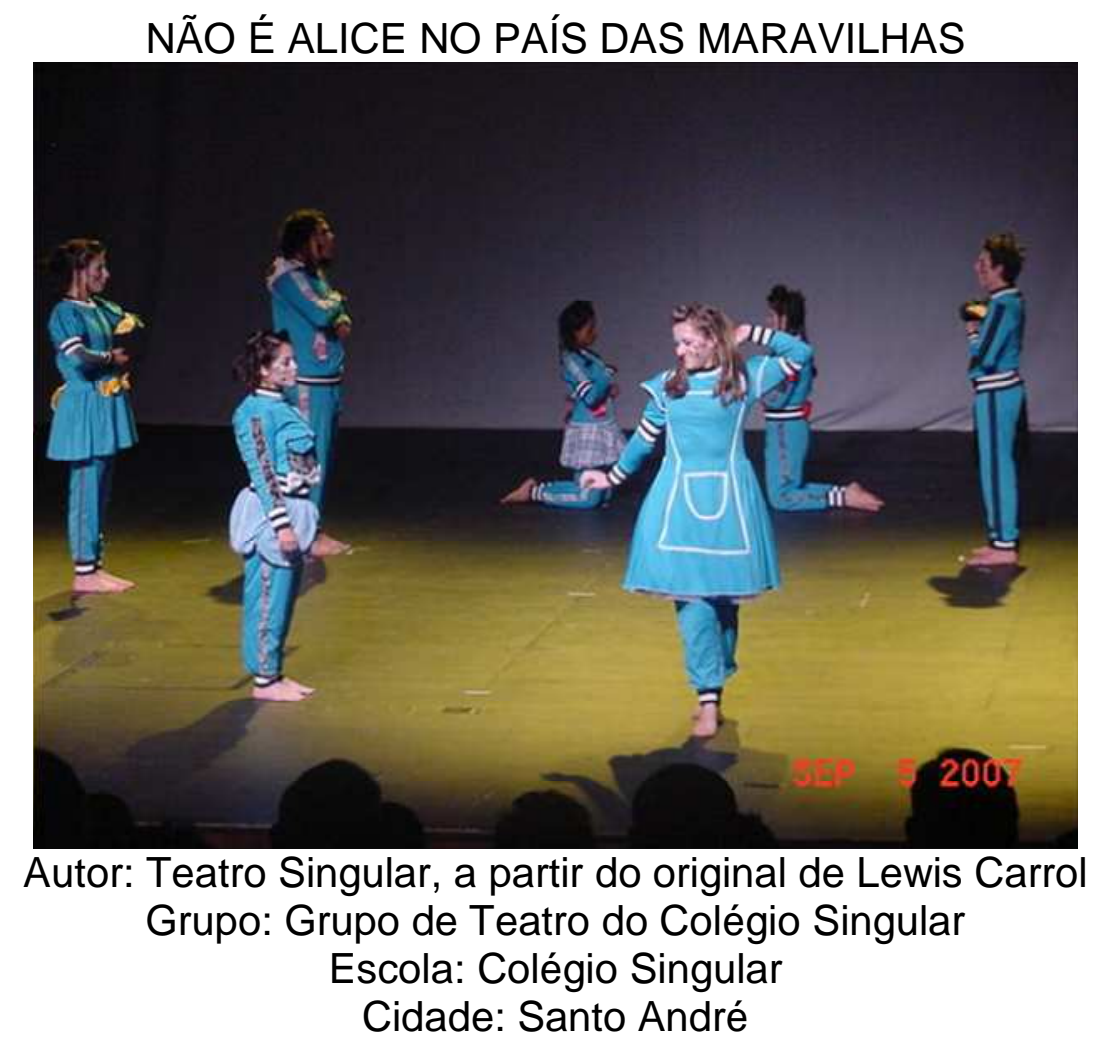

O espetáculo, com direção do professor artista Marcelo Gianini, ousado e com uma pesquisa de linguagem que nos leva a uma grande reflexão, traz um trabalho de corpo muito bem elaborado contendo jogos sempre presentes no processo de trabalho e com uma direção impecável. O espetáculo foi construído para um espaço alternativo e não palco italiano. 


\section{RELEASE}

Não é Alice no País das Maravilhas, o $15^{\circ}$ espetáculo do Teatro Singular utiliza o livro de Lewis Carroll (Alice no País das Maravilhas) como pretexto para um mergulho nos sonhos e desejos dos seres humanos. A peça não repete a história literária, vai além do texto dramático e se aproxima do teatrodança de Pina Bausch e do teatro de imagens de Bob Wilson. Em Não é Alice no País das Maravilhas, espelha-se em áreas da linguagem cênica ainda pouco exploradas no teatro brasileiro. $O$ foco vai além do texto dramático $\mathrm{e}$ está na exploração de sensações, sentimentos e idéias.

Direção: Marcelo Gianini Preparação Corporal: Ligia Helena Cenografia e Sonoplastia: Marcelo Gianini Operadora de som: Ligia Helena Iluminação e operação de luz: Jorge Pezzolo Figurinista: Renata Régis

\section{FICHA TÉCNICA E ARTÍSTICA} Costureira e Modelista: Maria José Gomes Pesquisa e Produção de Imagens: Caio Lacerda, Irina Serrano, Luma Reis, Marcelo Gianini e Tales Monteiro Contra regras: Tales Monteiro Produção: Colégio Singular.

\section{ELENCO}

Aline Cocco

Ana Carolina Novelli

Caio Lacerda

Carolina Ferraresi

Christina Pina

Clarissa Franchi Battistin Isabela Mercurt Daniele Rezende Sulimam

Heloísa Cardoso Leonardo Reitano Luma Reis Maria Carolina Irina Serrano Paulo Gyrcis 


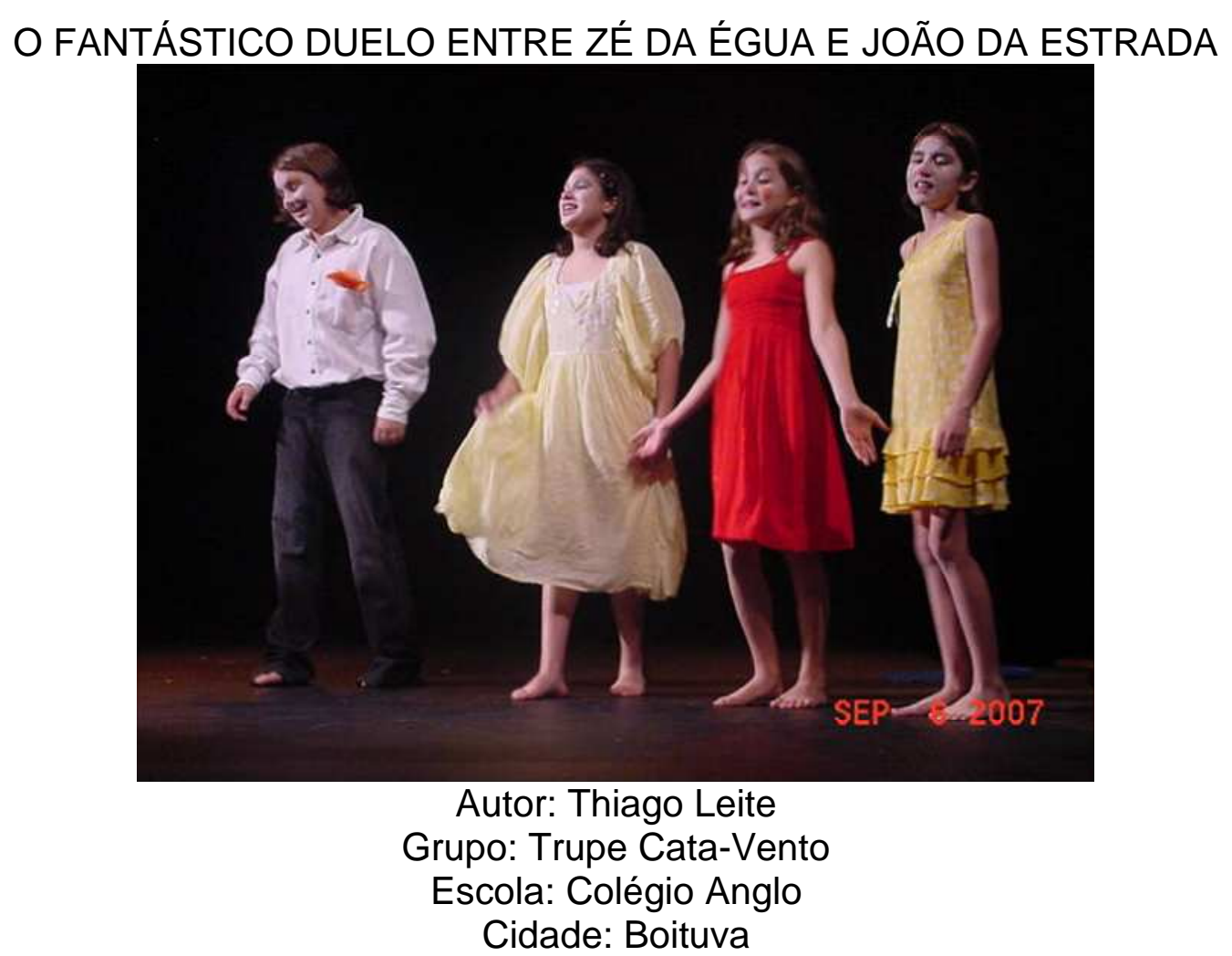

Com texto e direção do professor artista Tiago Leite, o espetáculo é um pouco precário, mas tem um foco e pesquisa de trabalho que não chega a contagiar a platéia, talvez por alguns equívocos na construção do trabalho. Durante o debate, os jurados sugerem uma maior atenção com relação ao texto que visivelmente prejudicou o espetáculo. 


\section{RELEASE}

A Trupe Cata-vento traz ao público a história de dois amigos que vivem em paz, na cidade de São José do Fim do Mundo, até a chegada de Berinéia, a famosa filha do Dr. Ramon. Ao se depararem com a beleza da moça, que ao voltar à cidade é recebida com um grande baile, ambos se mostram apaixonados e dão inicio a maior disputa de todos os tempos.

Direção: Thiago de Castro Leite

\section{FICHA TÉCNICA E ARTÍSTICA}

Sonoplastia: Thiago Leite

Violão: Vitor Oliveira Netto

Cenografia: Trupe Cata-vento

Iluminação: Thiago Leite

Operação de Luz: Laura Baggio

Contra-regragem: André Luis Camargo, Alex Dias Alves, Beatriz Gomes

Garcia, Glória Ventura, Erivelton Oliveira Lima, Marie Terashima Yoshizawa,

Osvaldo Ferreira, Mônica Magnano e Sandra Almeida

Coordenação Pedagógica: Giovana Gomes Garcia Góes

Diretora do Colégio: Maria Ângela Leis Vilela Baggio

\section{ELENCO}

Matheus Rodrigues

Gustavo Machado

Maria Eduarda Gomes

Marcela Fernandes Fleury

Ana Laura Holtz
Cainan Roncati

Maria Fernanda Barbosa Matheus Stinghini Melaré Bruna de Camargo

Kellen Rosa

Lucas Longuini
Thomas Mills

Adriano César Conti 


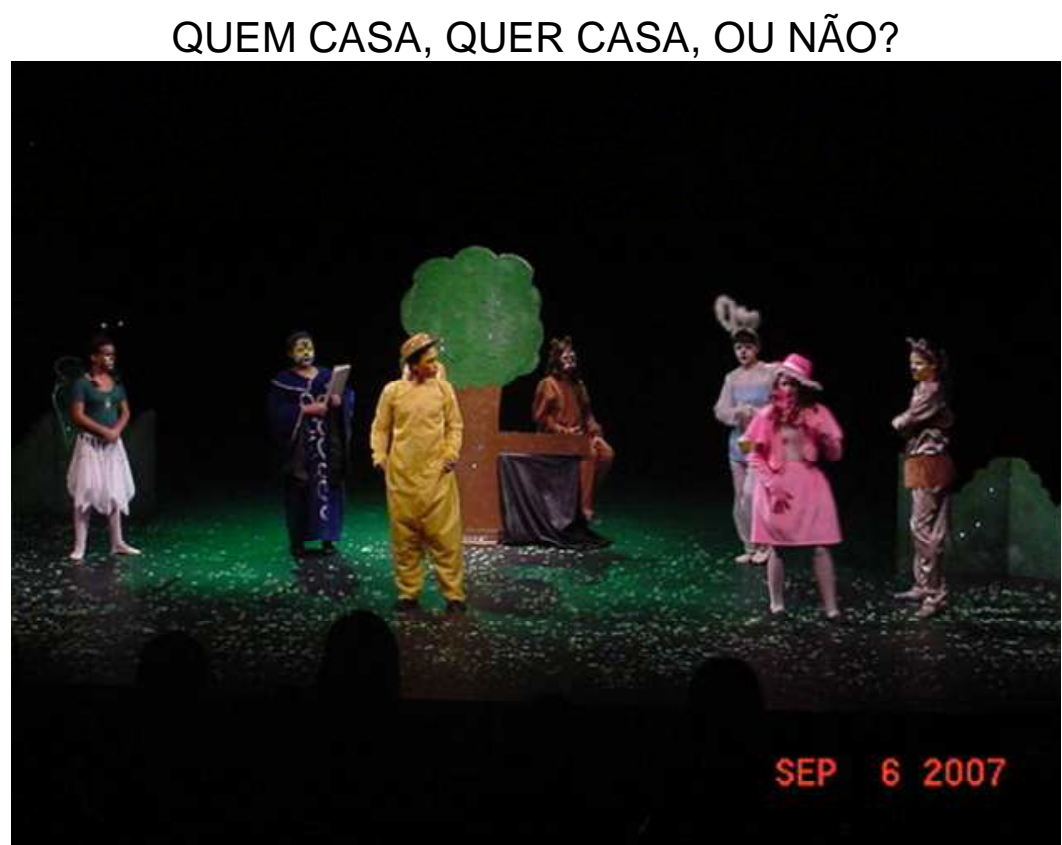

Autor: Tatiana Belinky

Grupo: Cia Teatral Quatro Cantos de Quadra

Escola: EMEF João Inácio Soares

Cidade: Quadra

Da cidade de Quadra, com direção do professor artista Benemare Sulivan, participa pela segunda vez do festival, porém agora com uma nova formação. Um espetáculo modesto sem grandes pretensões visivelmente com parcos recursos e um processo ainda um pouco deficiente, não compreendem direito como se deve trabalhar o jogo durante o processo. Durante o debate, essas questões foram levantadas e ficou muito evidente o interesse do grupo por tudo ali o que estava sendo falado, ressalto ainda o respeito que a comissão teve em apontar os erros. 


\section{RELEASE}

Uma história repleta de muita confusão e diversão. Assim podemos resumir a história do casal Lelé e Mujim. Ela, uma lesma dengosa e romântica que procura casamento. Ele, um caramujo resmungão e convencido mais que também procura uma noiva.

Quando se conhecem resolvem se casar... Mas será que esse casamento terá um final feliz?

\section{FICHA TÉCNICA E ARTÍSTICA}

Diretor: Benemari Sulivam

Maquinadora: Silvana Geraldine

Iluminador: Fábio Clasete Rodrigues

Sonoplastia: Benemari Sulivam

Contra regra: Edivana Mendes, Vânia Antunes e Lida Camargo

Daniel Barbosa Jr.

\section{ELENCO}

Josimara Martinhs

Regiane de Oliveira

Leticia Urbanjos

Marcos Augusto Gonçalves

Rubia Quadros

Kerulyn Tuane

Darlison Mariano de Barras 


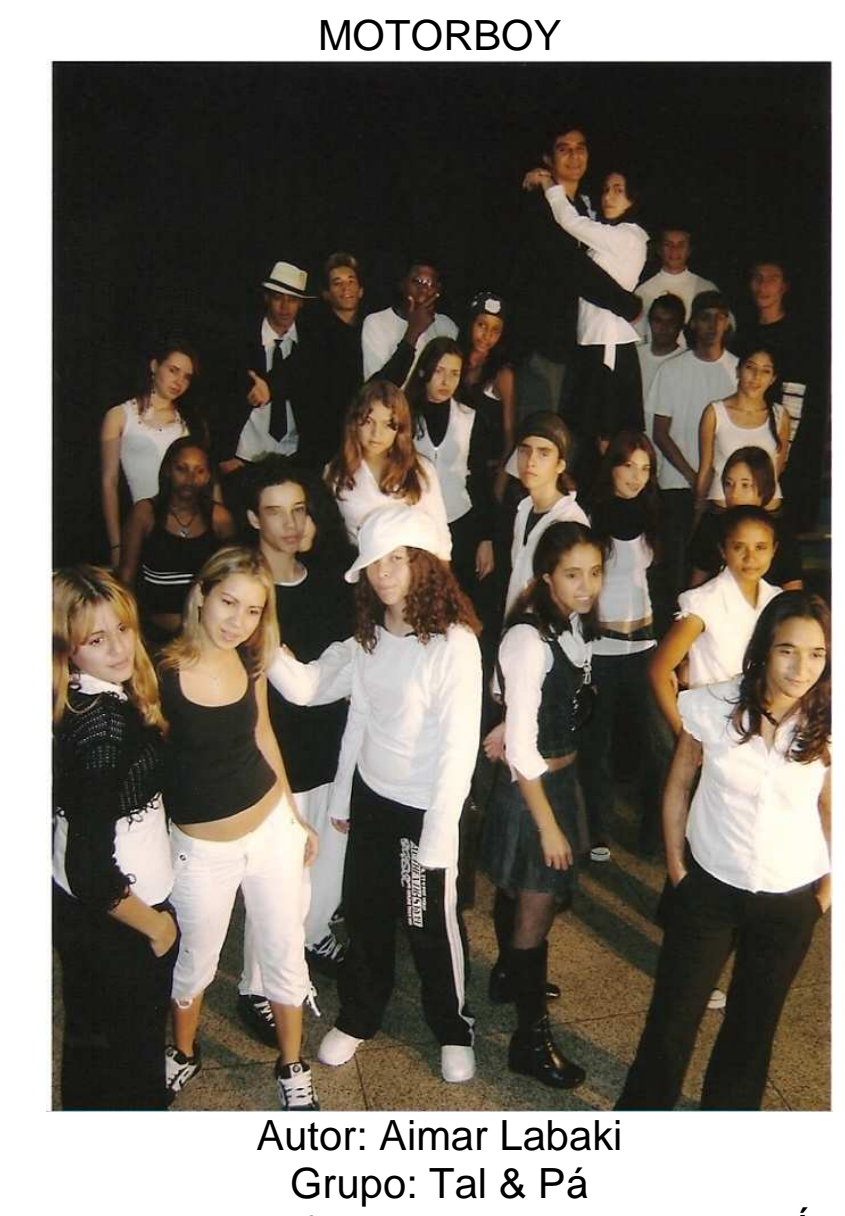

Escola: E.E. Professora Maria Augusta de Ávila Cidade: São Paulo

Dirigida pela professora artista Valéria de Oliveira, Motorboy apresenta um espetáculo com algumas deficiências para o trabalho que o grupo já vem desenvolvendo há anos. Talvez tenham sido por causa das dificuldades que o grupo passa para sobreviver, que tenha refletido no processo e resultado finais. Isto ficou muito evidente durante o debate, quando a professora artista colocou o que acontecia com o grupo naquele momento como, por exemplo, o fato de estarem sendo despejados da escola onde executavam o trabalho. A comissão julgadora ressaltou a importância do trabalho que era desenvolvido naquela escola e comunidade e os parabenizou pelo espetáculo. 


\section{RELEASE}

Dirigida ao público adolescente, a peça fala de seus dramas, conflitos familiares e pessoais, mas também de suas perspectivas, ao narrar as aventuras cotidianas de um grupo de motoboys. A personagem central, Cristina, é uma garota que, traumatizada por um estupro, se disfarça de rapaz. Em meio às dificuldades do primeiro emprego, defendendo valores como caráter e responsabilidade, ela descobre o amor e a liberdade.

\section{FICHA TÉCNICA E ARTÍSTICA}

Direção geral: Valéria de Oliveira Direção e Produção Musical: Soraya de Oliveira Coreografia: Ariovaldo Jr. Coordenação Técnica: Carina Viana e Alexandre Naves Preparação Corporal: Alairton Lopes Preparação Vocal: Ingrid Bonatto Cenografia: Karoline Pinheiro Iluminação: Alexandre Naves e Henrique Andrade

\begin{tabular}{ll} 
& \multicolumn{1}{c}{ ELENCO } \\
Alairton Lopes & Felipe Lorenzini \\
Aline Oliveira & Fernanda Silva \\
Aline Rodrigues & Gisele Tenório \\
Aline Souza & Ingrid Bonatto \\
Ângelo Favero & Itamar Fernandes \\
Caio Nunes & Jaqueline Armando \\
Camila Nabarro & Juliana Clemente \\
Débora Brasil & Kamila Moura \\
Déborah Hathner & Karoline Pinheiro
\end{tabular}
Operador de som: Wesley Andrade e Soraya de Oliveira Contra regras: Douglas Mora, Tony Leão, Cristiana Fabricio, Tati Fabrício e Lúcia Leão Figurinos: grupo Pesquisa: grupo Apoiadores: Helena de Oliveira, Eliana Mendes e Simone Ferraresi
Luis Ferndandes Marcus Vinicius Maria Souza Nathália Silva Rafael Fabricio Rafael Rigler Renan Santos Sheriton Silva Wagner de Freitas 


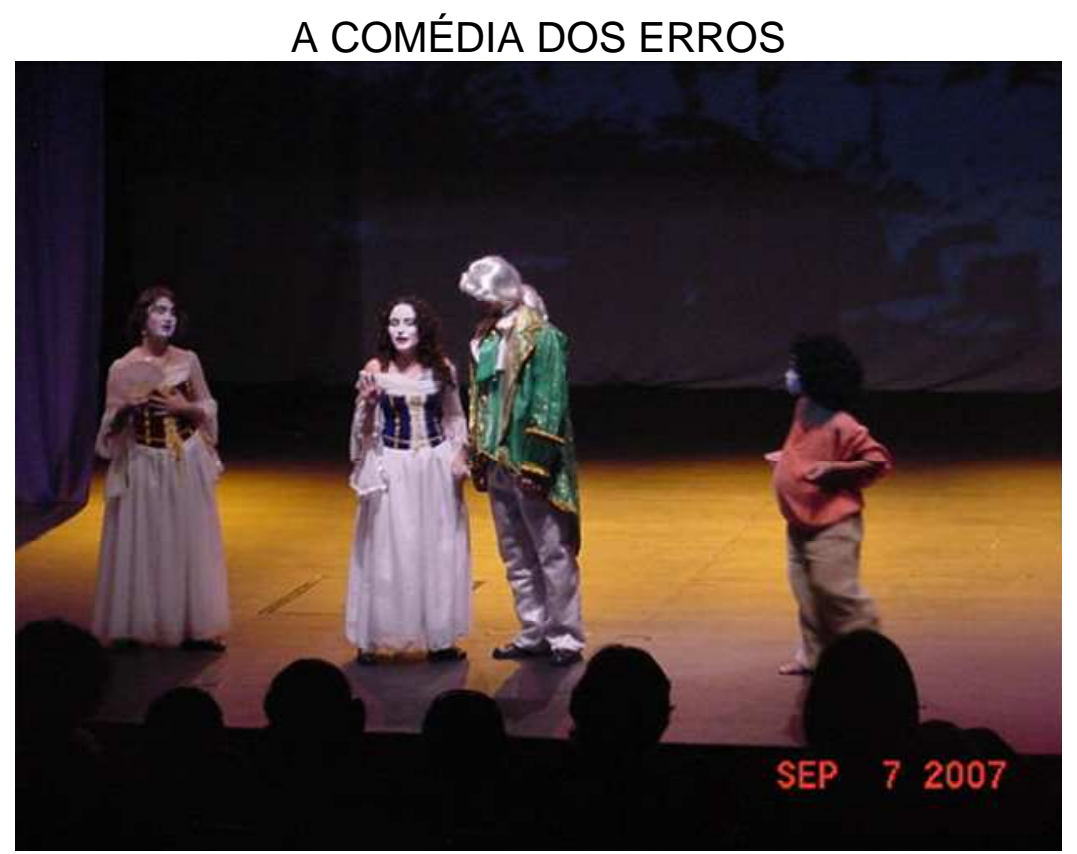

Autor: William Shakespeare, Adaptação: Valéria Marchi

Grupo: Grupo do Colégio EMECE

Escola: Colégio Emece

Cidade: São Paulo

Adaptado e dirigido pela professora artista Valéria Marchi, o espetáculo apresenta alguns acertos como iluminação e trilha sonora. O elenco conhece sobre o assunto mas é um espetáculo que não chega a acontecer durante a sua apresentação, como foi já foi dito a professora artista desenvolve esse trabalho extracurricular e é a segunda vez que participa desse festival. Durante o debate, a comissão julgadora ressaltou alguns pontos, entre eles de se fazer um texto mais apropriado para a idade dos alunos, no entanto a iluminação foi muito elogiada. 


\section{RELEASE}

Esse espetáculo é uma adaptação feita a partir do original de William Shakespeare. Nesta movimentada comédia dois pares de gêmeos, separados ainda na tenra infância e morando em cidades diferentes, vivem as mais engraçadas situações quando se encontram simultaneamente na cidade de Éfeso. Até que eles se encontrem, muitas confusões e desencontros acontecem, nessa que é uma das mais hilariantes comédias do maior dramaturgo de todos os tempos.

Direção: Valéria Marchi

\section{FICHA TÉCNICA E ARTÍSTICA}

Iluminação: Érika Bodstein

Trilha Sonora: Valéria Marchi

Figurinos: grupo

Monitores: Roseni de Lisboa. Maria Luiza de Toledo e Sandra de Araújo

ELENCO

André Furegate

Beatriz Azevedo Ferrari

Camila Araújo

Camila Antiquera Silva

Esther Simões Toledo

Gabriela Pinheiro

Iratã Lisboa Rocha

Jéssica Simões Toledo

Mariana Domingues Facchini

Rômulo Villela

Thiago de Biase Rodrigues 


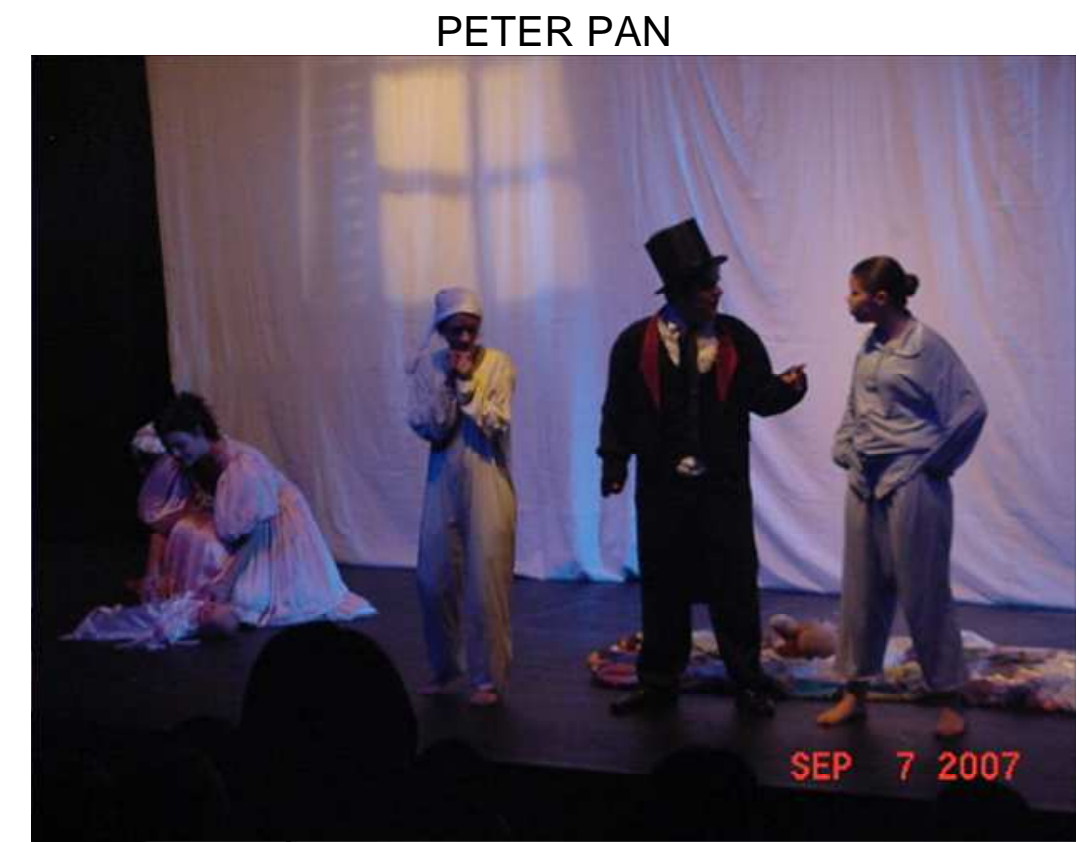

Autor: Adaptação de Érica Bodstein para a obra de James Matew Barrie.

Grupo: Grupo do Colégio Imperatriz Leopoldina

Escola: Colégio Imperatriz Leopoldina

Cidade: São Paulo

Com direção da professora artista Érika Bodstein, o espetáculo vem com uma cenografia suntuosa e com figurinos muito bem elaborados, mas não chega a encantar o público, embora tenha um grande apelo visual. A comissão julgadora ressalta a importância de ser retomada a função dos jogos e de levar em consideração o que as crianças desejam realizar como teatro. 
RELEASE
A partir do original Peter \& Wendy de James Mattew Barrie, esta adaptação procura resgatar a beleza da verdadeira história de Peter Pan, com toda a força de suas personagens, numa aventura deliciosa que vai encantar todas as crianças, principalmente aquelas que moram em nossos corações.

Direção: Erika Bodstein

\section{FICHA TÉCNICA E ARTÍSTICA}

lluminação e trilha sonora: Érika Bodstein

Figurinos: Valéria Marchi

Técnico de Som: Mariana Camargo

Técnico de Luz: Marco Piá

Maquiagem: Armando Pinheiro

Monitores: Norma Porto e Evelyn Beck

Ana Frida

Augusto Ruy

Bruna Zampollo

Carolina Rateiro

Caroline Ap. Ferndandes

Daniel Santos

Felipe Luís

Heloísa Pimentel

Humberto Tozzi

\section{ELENCO}

Julia Vasconcellos

Juliana Ostini

Laís Paulon

Lais Pestana

Larissa Patta

Lia Rodrigues

Marilia Beatriz Gomes

Martins Müller Anselment

Vitor Mello Cantagesso 


\section{JOSÉ E SEU MARAVILHOSO CASACO DE SONHOS COLORIDO}

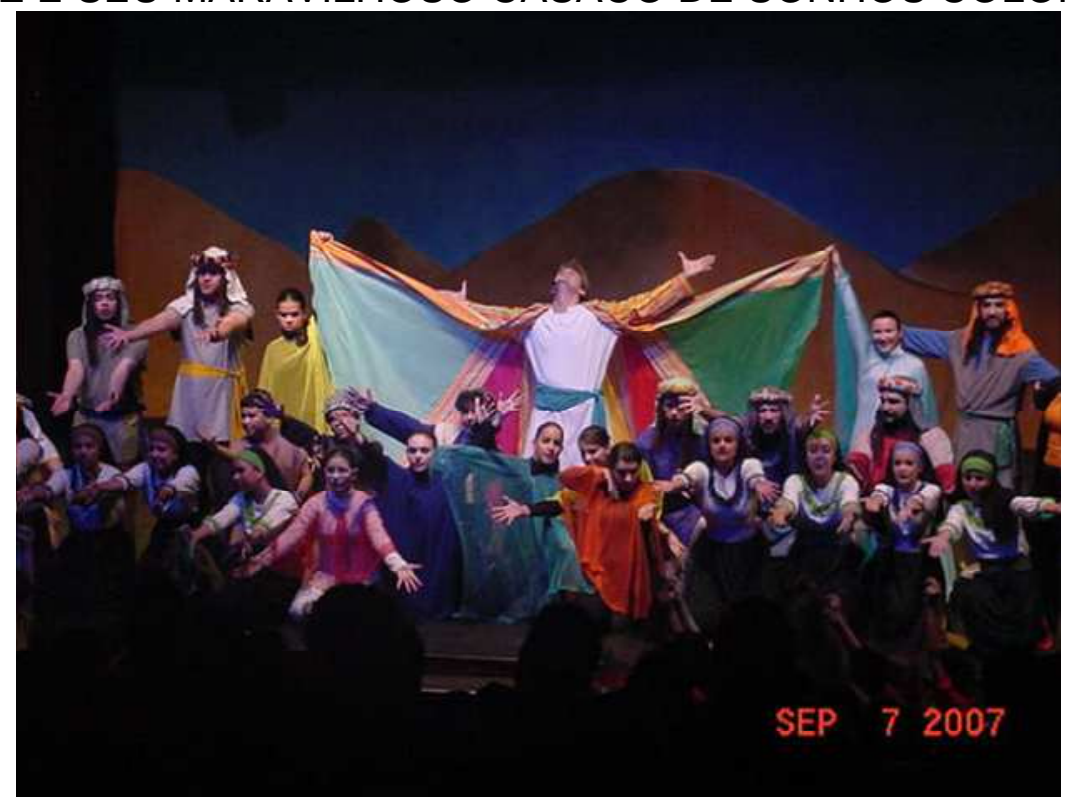

Autor: Pámela Paz e Cris Lima

Grupo: Grupo Teen de Teatro

Escola: Colégio Santo Agostinho

Cidade: São Paulo

Com o espetáculo musical, em que misturam alunos, professores e funcionários da escola, a professora artista Pámela Paz traz um espetáculo que contagia e emociona a platéia. Espetáculo que tem inúmeros acertos de figurino, cenografia e músicas que dão um enriquecimento melhor ao espetáculo. Os alunos, professores e funcionários se deliciam ao fazer 0 espetáculo, adereços surpreendentes aparecem em cena e o palco é tomado por atores e cantores, conquistando a todos da platéia. A comissão julgadora elogia o espetáculo, mas contesta um pouco o processo de trabalho. 


\section{RELEASE}

José é o preferido entre os 12 filhos de Jacó que, ao lhe presentear com um lindo casaco colorido, alimenta a antipatia dos outros irmãos. Num ímpeto de ciúmes eles the arrancam o presente e o vendem para o Egito, fato que mudará a vida de José e fará verdade todos seus sonhos que pareciam tão impossíveis. A história - baseada num episódio bíblico - é narrada por uma professora de forma bem peculiar, interagindo entre alunos e personagens através deste grande musical.

\section{FICHA TÉCNICA E ARTÍSTICA}

Direção Geral - Pamela Paz Versão das Músicas: Fábio Hilst Assistente de Direção: Henrique Faria Trilha Sonora e Arranjos Musicais: Gilson Faria

Regência do Coral: Professora Elisa Varro Coreografias: Inara Santos Cenário: Gilson Faria
Adereços: Cris Lima .Gilson Faria Adereços para o grupo: Mônica Overbeck Confecção de Adereços e Cenário: Grupo teen Operadora de Som: Giovanna Rossi Operador de Luz: Rebeka Fanti Contra Regra: Marcos Melin Confecção do Figurino: Rosa Fazenda.
Daniella Restani Mario Cantarin Antônio Veiga Fernando Conceição José Carlos Demarchi Rafael Gabriel e Silva Raul Sanches José Randal Guilherme Varro Rubens Santana Gustavo Mendes Henrique Faria Matheus Ross Geraldo Vidal Lilian Locchesi David Orlando Gabriel e Silva José Carlos Demarchi Iris Ramos Sarah Sangali Thaysa Iris Ramos Jordana Chaves Karinne Kelly Maria Clara Paiva Marília

Raquel Paiva

Renata Di Tomasso

Sarah Sangali

Thaysa

Juliana Almeida

Raquel Paiva

Adriana Politano

Elisa Varro

Maria Luisa Bloise Mônica Chapchap

Viviane Miceli

Carla Stephanie

Isabelle Primo Juliana Almeida Natalia Sales Camila Almeida Gabriela Foliene Flavia Artuso Ayrina Pelegrino Bailarinas: Ariza Bueno, Inara Santos, Iris Ramos, Jordana Chaves, Karini Afonso, Karinne Kelly, Maria Clara Paiva, Maria Luisa Varro, Marília,
Renata Di Tomasso, Sarah Sangali, Thaysa

CORAL: Tarcísio Luiz Barrile, Natalia Ramos, Alessandra Emy, Paola Yuu Tabata, Rafaella Delahio, Vinícius de Moraes,

Gabriel Ciara, Isabella Franchini, Dayane da Silva, Bianca Victória, Ana Lúcia Biassi Rangel, Caio Gracco Lima, Pietra B. Fontana, Gabriela R Nascimento, Clarissa Ricci, Luis Henrique Gregório, Daniela Losano, Alice Eglioto, Thayna da Silva, Stephanie Maya, Mariana Paula, Juliana Artuso, Natalia Machado, João Paulo Lawrence, Caio Yuiti T. Furukawa, Beatriz Helena Cunha, Camila Mitie, Alef Luiz Adriano, Heloisa Catani, Marcus Vinicius dos Santos, Enzo Takashi, Marina Mito, Beatriz Tiemi, Danilo Da Silva, Gabriel Manso, Thaís Machado, Rayssa Missue, Maria Clara Franco, Matheus C. Ajauskas.

\section{ELENCO}


PREMIAÇÃO CATEGORIA INFANTIL

\begin{tabular}{|c|c|c|c|c|c|c|}
\hline & $\begin{array}{c}\text { UMA LENDA } \\
\text { DA } \\
\text { AMAZÔNIA }\end{array}$ & $\begin{array}{c} \\
\text { SALVAMENT } \\
\text { O DA } \\
\text { PALMEIRA }\end{array}$ & $\begin{array}{c}\text { QUEM TE } \\
\text { CONTAVA } \\
\text { HISTÓRIAS }\end{array}$ & $\begin{array}{l}\text { QUEM CASA, } \\
\text { QUER CASA, } \\
\text { OU NÃO? }\end{array}$ & PETER PAN & $\begin{array}{c}\text { O RARTINHO } \\
\text { QUE QUERIA } \\
\text { A LUA }\end{array}$ \\
\hline \begin{tabular}{|l|} 
ATOR \\
REVELAÇÃO
\end{tabular} & & $\begin{array}{c}\text { CAINAN } \\
\text { RONCATI }\end{array}$ & & & & \\
\hline \begin{tabular}{|l|} 
ATRIZ \\
REVELAÇÃO
\end{tabular} & & $\begin{array}{l}\text { LETICIA } \\
\text { SIQUEIRA }\end{array}$ & & & & \\
\hline $\begin{array}{l}\text { COADJUVANTE } \\
\text { MASCULINO }\end{array}$ & & & & $\begin{array}{c}\text { MARCOS } \\
\text { AUGUSTO } \\
\text { GONÇALVES }\end{array}$ & & \\
\hline $\begin{array}{l}\text { COADJUVANTE } \\
\text { FEMININO }\end{array}$ & $\begin{array}{c}\text { ÉVELIN } \\
\text { FERRAZ E } \\
\text { MARY AVANZI }\end{array}$ & & & & & \\
\hline CENOGRAFIA & & & TÂNIA BOY & & & \\
\hline ILUMINAÇÃO & & & & & & \\
\hline FIGURINO & & & & $\begin{array}{l}\text { BENEMARI } \\
\text { SULIVAN }\end{array}$ & & \\
\hline MAQUIAGEM & $\begin{array}{l}\text { MARCELO } \\
\text { SATURNO }\end{array}$ & & & & & \\
\hline SONOPLASTIA & & & TÂNIA BOY & & & \\
\hline DIREÇÃO & & & $\begin{array}{c}\text { TÂNIA BOY E } \\
\text { CAMILA } \\
\text { ROCHA }\end{array}$ & & & \\
\hline MELHOR ATOR & & & & & & $\begin{array}{l}\text { RENATO } \\
\text { RIBEIRO }\end{array}$ \\
\hline $\begin{array}{l}\text { AMELHOR } \\
\text { ATRIZ }\end{array}$ & & & & & $\begin{array}{l}\text { JULIANA } \\
\text { OSTINI }\end{array}$ & \\
\hline $\begin{array}{l}\text { MELHOR ESPETÁCULO } \\
\text { JURI POPULAR }\end{array}$ & & & & $\begin{array}{l}\text { QUEM CASA, } \\
\text { QUER CASA, } \\
\text { OU NÃO? }\end{array}$ & & \\
\hline $\begin{array}{l}\text { MELHOR } \\
\text { ESPETÁCULO }\end{array}$ & & & $\begin{array}{c}\text { QUEM TE } \\
\text { CONTAVA } \\
\text { HISTORIAS }\end{array}$ & & & \\
\hline $\begin{array}{l}\text { 20 MELHOR } \\
\text { ESPETÁCULO }\end{array}$ & & $\begin{array}{c}0 \\
\text { SALVAMENT } \\
\text { O DA } \\
\text { PALMEIRA }\end{array}$ & & & & \\
\hline
\end{tabular}


PREMIAÇÃO CATEGORIA ADULTO

\begin{tabular}{|c|c|c|c|}
\hline & $\begin{array}{c}\text { SONHOS DE UM LINDO } \\
\text { BRASIL }\end{array}$ & $\begin{array}{l}\text { OF FANTÁSTICO DUELA ENTTE ZÉ DA } \\
\text { EGUA E O JOÄP DA ESTRADA }\end{array}$ & A COMÉDIA DOS ERROS \\
\hline ATOR REVELAÇÃO & $\begin{array}{l}\text { FELIPE ARRUDA } \\
\text { RODRIGUES }\end{array}$ & & \\
\hline ATRIZ REVELAÇÃO & $\begin{array}{l}\text { DANIELA SILVA DE } \\
\text { QUADROS }\end{array}$ & & \\
\hline $\begin{array}{l}\text { COADJUVANTE } \\
\text { MASCULINO }\end{array}$ & & $\begin{array}{c}\text { MATEUS RODRIGOS DE } \\
\text { OLIVEIRA }\end{array}$ & \\
\hline $\begin{array}{l}\text { COADJUVANTE } \\
\text { FEMININO }\end{array}$ & & & $\begin{array}{c}\text { GABRIELA PINHEIRO } \\
\text { MUNDIN }\end{array}$ \\
\hline CENOGRAFIA & & & O GRUPO \\
\hline ILUMINAÇÃO & GRUPO & & \\
\hline FIGURINO & & O GRUPO & \\
\hline MAQUIAGEM & & & GRUPO \\
\hline SONOPLASTIA & GRUPO & & \\
\hline DIREÇÃO & GRUPO & & \\
\hline MELHOR ATOR & VITOR GABRIEL & & \\
\hline AMELHOR ATRIZ & & & ESTHER SIMÕES \\
\hline $\begin{array}{l}\text { PEDAGOGIA DO } \\
\text { TEATRO }\end{array}$ & & THIAGO LEITE & \\
\hline $\begin{array}{l}\text { MELHOR } \\
\text { ESPETÁCULO JURI } \\
\text { POPULAR }\end{array}$ & $\begin{array}{c}\text { SONHOS DE UM LINDO } \\
\text { BRASIL }\end{array}$ & & \\
\hline $\begin{array}{l}\text { MELHOR } \\
\text { ESPETÁCULO }\end{array}$ & $\begin{array}{c}\text { SONHOS DE UM LINDO } \\
\text { BRASIL }\end{array}$ & & \\
\hline
\end{tabular}


PREMIAÇÃO CATEGORIA LIVRE

\begin{tabular}{|c|c|c|c|c|c|}
\hline & $\begin{array}{l}\text { AS AVENTURAS DE PETER } \\
\text { E WENDY NA TERRA DO } \\
\text { NUNCA }\end{array}$ & $\begin{array}{l}\text { O SANTO E A } \\
\text { PORCA }\end{array}$ & $\begin{array}{l}\text { NÄO É ALICE NO PAís } \\
\text { DAS MARAVILHAS }\end{array}$ & MOTORBOY & $\begin{array}{c}\text { JOSEE E SEU } \\
\text { MARAVILHOSO } \\
\text { CASACO DE SONHOS } \\
\text { COLORIDOS }\end{array}$ \\
\hline $\begin{array}{l}\text { ATOR } \\
\text { REVELAÇÃO }\end{array}$ & ANTÔNIO PANIS & & & & \\
\hline $\begin{array}{l}\text { ATRIZ } \\
\text { REVELAÇÃo }\end{array}$ & $\begin{array}{l}\text { CAMILA } \\
\text { LALESSO }\end{array}$ & & & & \\
\hline $\begin{array}{l}\text { COADJUVANTE } \\
\text { MASCULINO }\end{array}$ & ADAUTO PARRÉ & & & & \\
\hline $\begin{array}{l}\text { COADJUVANTE } \\
\text { FEMININO }\end{array}$ & $\begin{array}{l}\text { HAYA } \\
\text { MEDEIROS }\end{array}$ & & & & \\
\hline CENOGRAFIA & & & & $\begin{array}{l}\text { KAROLINE } \\
\text { PINHEIRO }\end{array}$ & \\
\hline ILUMINAÇÃO & & & $\begin{array}{l}\text { JORGE } \\
\text { PEZZOLO }\end{array}$ & & \\
\hline FIGURINO & & & RENATA REGIS & & \\
\hline MAQUIAGEM & O GRUPO & & & & \\
\hline SONOPLASTIA & & & $\begin{array}{l}\text { MARCELO } \\
\text { GIANINI }\end{array}$ & & \\
\hline \multicolumn{6}{|l|}{$\begin{array}{l}\text { MELHOR } \\
\text { COREOGRAFIA }\end{array}$} \\
\hline DIREÇÃO & & & $\begin{array}{l}\text { MARCELO } \\
\text { GIANINI }\end{array}$ & & \\
\hline MELHOR ATOR & $\begin{array}{l}\text { JHONNY } \\
\text { MEDEIROS }\end{array}$ & & & & \\
\hline $\begin{array}{l}\text { AMELHOR } \\
\text { ATRIZ }\end{array}$ & & & & DEBORA HATER & \\
\hline COREOGRAFIA & & & & ARIOVALDO JR. & \\
\hline $\begin{array}{l}\text { PRODUÇ̃̃o INTEGRADA } \\
\text { DE MUSiCAL }\end{array}$ & & & & & $\begin{array}{c}\text { JOSÉ E SEU } \\
\text { MARAVILHOSO } \\
\text { CASACO DE SONHOS } \\
\text { COLORIDOS }\end{array}$ \\
\hline $\begin{array}{l}\text { MELHOR ESPEET́CULO } \\
\text { JURI POPULAR }\end{array}$ & $\begin{array}{l}\text { AS AVENTURAS DE PETER } \\
\text { E WENTY NA TERRA DO } \\
\text { NUNCA }\end{array}$ & & & & \\
\hline $\begin{array}{l}\text { MELHOR } \\
\text { ESPETÁCULO }\end{array}$ & & & $\begin{array}{l}\text { NÃO É ALICE NO PAIS } \\
\text { DAS MARAVILHAS }\end{array}$ & & \\
\hline $\begin{array}{l}\text { 2 MELHOR } \\
\text { ESPETÁCULO }\end{array}$ & $\begin{array}{l}\text { AS AVENTURAS DE PETER } \\
\text { E WENDY NATERRA DO } \\
\text { NUNCA }\end{array}$ & & & & \\
\hline
\end{tabular}




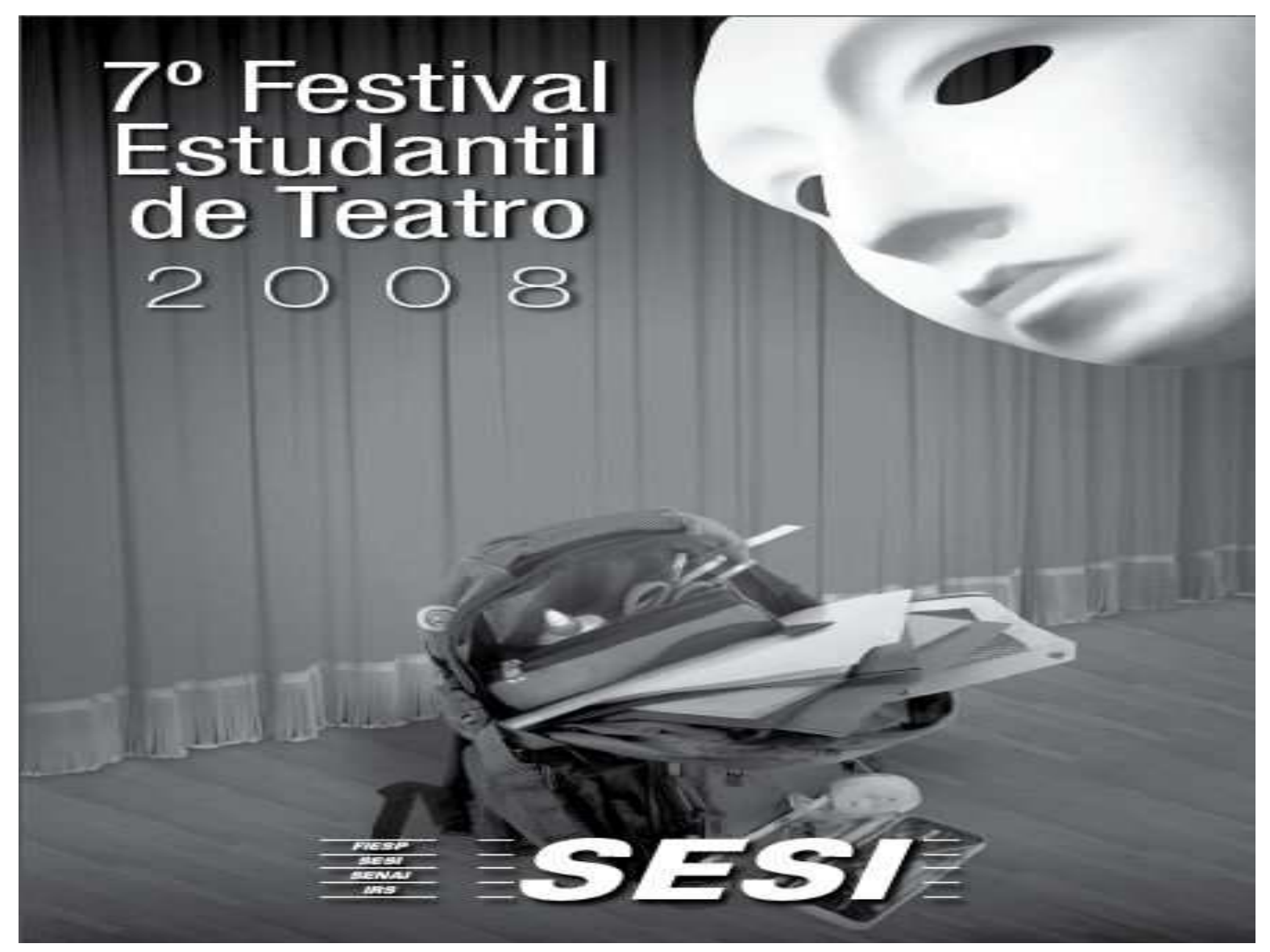




\section{7ํ Festival Estudantil Sesi de Teatro 2008}

O $7^{\circ}$ Festival Estudantil de Teatro retomou novamente as duas categorias: "Teatro para Criança" e "Teatro Adulto". Os grupos que se apresentaram e já participaram de outras edições mostraram maturidade no desenvolvimento do trabalho e foram analisados por Clóvis Garcia, Silnei Siqueira e Ingrid Dormiem Koudela, que também foi mais uma vez responsável pela curadoria do Festival.

Este ano, uma nova lei das escolas públicas proibia a saída dos seus alunos em horário de aula para atividades extracurriculares, para estas saídas era necessária a elaboração de um projeto com antecedência para uma autorização junto à diretoria de ensino, o que dificultou a participação de algumas escolas que estavam habituadas a assistirem o festival, mas um fato marcante foi o de alguns professores que quebraram as regras e levaram os seus alunos para assistirem aos espetáculos, apesar da proibição. O que vem abonar junto à organização do festival que escolas públicas e particulares, já entendem e sabem da necessidade do contato de seus alunos com o teatro. Nossa platéia sempre foi formada por alunos e comunidades, muitas vezes escolas chegam em ônibus lotados e todos os alunos são recolhidos para dentro do teatro, mesmo tendo que ocupar espaços nas escadas e laterais, sem fazer agendamento, o que para nós é de grande satisfação.

Durante o período da manhã, os atores e diretores alojados participaram de uma oficina de teatro: "A pedagogia no Teatro" com a Ms Marli Bonome, que trabalhou durante a semana, questões levantadas sobre os processos de criação dos espetáculos ali apresentados.

Um grande referencial no Festival foi o fechamento com o espetáculo: Chamas na Penugem, realizada pelo curso de Licenciatura de Teatro da UNISO, em que e os participantes do festival puderam entender a importância dos jogos teatrais que tanto é ressaltado nos debates. 
O festival desse ano, não teve nenhum ponto preocupante apenas só nos leva a refletir que, cada vez mais, deve se empenhar na luta pelo teatro nas escolas encabeçada pelos estudantes. E que a Idéia do Teatro Estudantil não faz parte de muitos que pensam o teatro, ainda o fato de que somos poucos, mas com força para lutar por cidades como Quadra, com duas escolas, onde alunos da zona rural têm contato com a arte e venham saborear e dividir experiências com alunos que provêm de uma grande metrópole, como São Paulo. Entendemos que a luta é árdua e que o teatro do estudante é marcado por grandes desafios, mas esperamos chegar a mais edições desse festival.

Esperamos que representantes da cultura e autoridades dispensem alguns dos seus minutos e olhem para projetos significativos como este.

Não podemos esquecer os nossos estudantes, não podemos esquecer o nosso teatro, não podemos esquecer a nossa comunidade, não podemos esquecer a nossa vida quando ela está totalmente ligada ao fazer teatral. Isso não pode desaparecer. 


\section{A LENDA DE PLUFT}

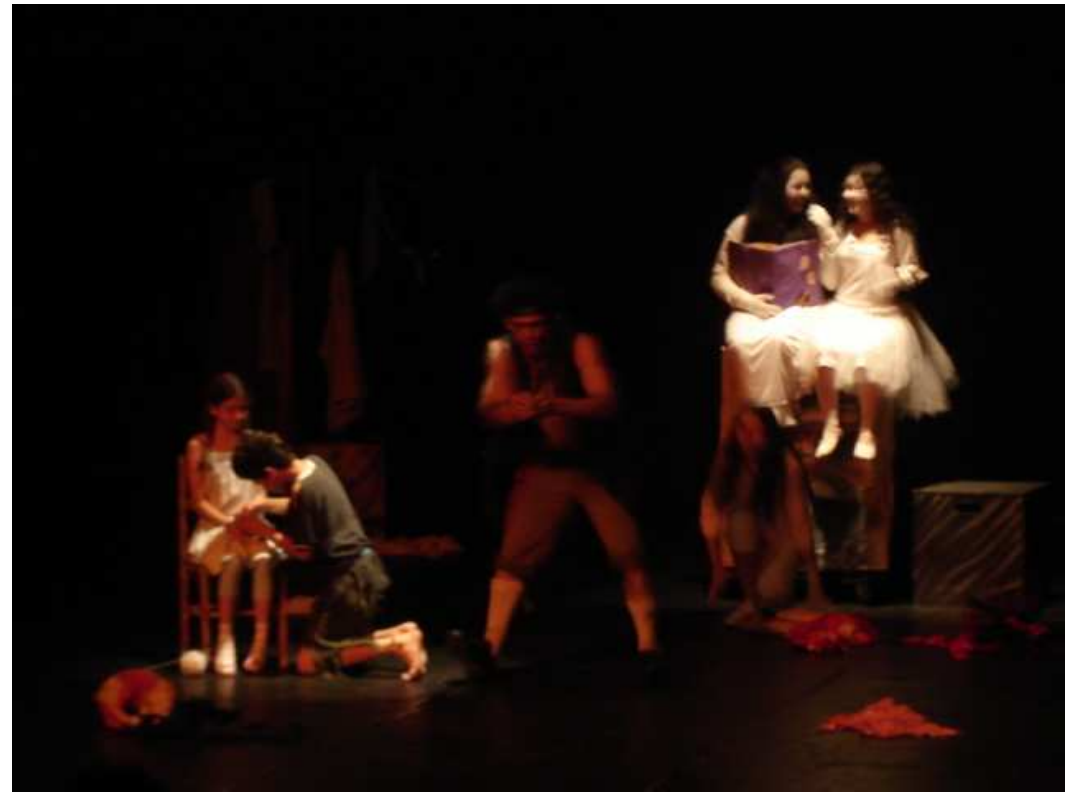

Autor: Maria Clara Machado, Adaptação de Fábio Jurera Grupo: Grupo Teatral Tapanaraca Mutatis Mutandis Escola: E.E. Professor Abílio Fontes e Instituto Peixoto Gomide.

Cidade: Itapetininga

Do grupo Tapanaraca, com direção de Fábio Jurera, o espetáculo é uma adaptação, mais precisamente uma releitura da obra de Maria Clara Machado. O espetáculo perde um pouco na atuação de duas atrizes que ficam o tempo todo no palco quase que inertes, mas tem um acerto no figurino e sonoplastia, talvez a direção tenha se equivocado na releitura do texto. Durante o debate, 0 ponto levantado pela comissão foi justamente a questão da modificação do texto. 


\section{RELEASE}

Pluft é um fantasminha muito esperto que vive com sua mãe no sótão de uma velha casa à beira-mar. Tudo ia bem até a chegada inesperada do terrível pirata Perna de Pau e seu ajudante Olho de Vidro, que aparecem à caça de um tesouro escondido naquela velha casa.

Uma aventura repleta de emoção e suspense que mostra a união de dois mundos para uma vitória em comum, e a superação de desafios, já que Pluft é um fantasminha que tem muito medo de gente e Maribel é uma menina que tem muito medo de fantasma.

\section{FICHA TÉCNICA E ARTÍSTICA}

Direção e Adaptação: Fábio Jurera Sonoplastia e lluminação: Lucy Villar

\section{ELENCO}

Juninho Ferreira

Felipe Almeida

Silvia Coutínho Raíssa Dandy Maryana Silva Carolina Haubt Ana Lu Hungria Juliare Caroline Geise Leite Beatriz Kobaiashi
Cyndi Adrielly Laura Busch Marckos Phellype Beatriz Oliveira Juju Kin Marina Alguz Julia Rangel Diego Pereira Andréa Vaz. 


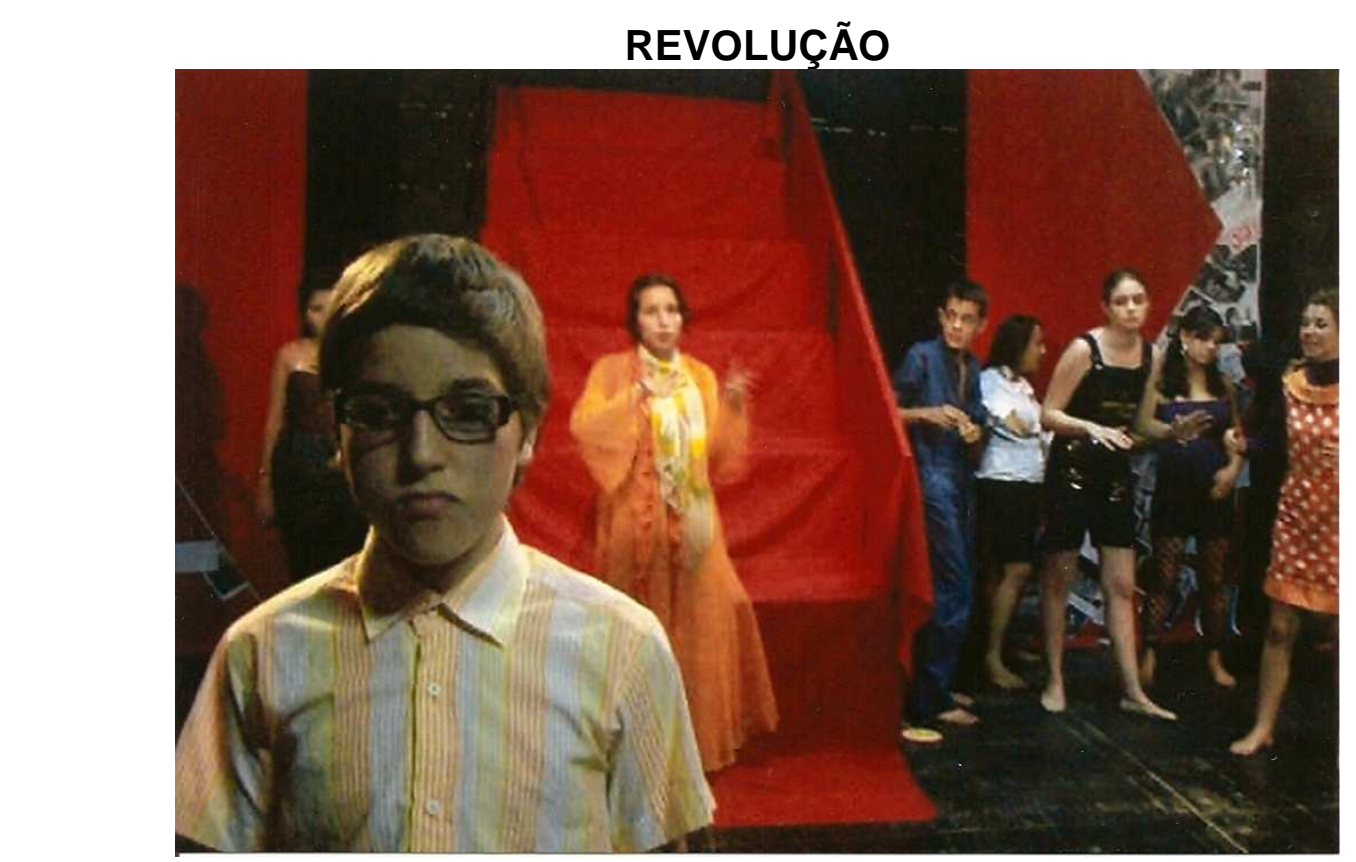

Baseado nas obras de Augusto Boal, Gianfrancesco Guarnieri e outros grandes Grupo: Núcleo Descobrir de Teatro

Cidade: Sorocaba - SP

Escola: Associação Teatral de Sorocaba (ATS)

Do núcleo Descobrir Teatro, com direção de Carlos Doles, o espetáculo surpreendeu pela sua irreverência e pela maneira atual que colocou os assuntos discutidos no palco. A sonoplastia teve uma grande força. Apenas o espetáculo poderia ter alguns cortes, pois tinham cenas que se faziam desnecessárias. Durante o debate, o espetáculo foi muito elogiado e também a comissão sugeriu possíveis recortes em algumas cenas. 


\section{RELEASE}

Espetáculo teatral que surge como resultado de uma pesquisa prática pelo universo da Dramaturgia Brasileira. Narra, de forma fragmentada, a trajetória da personagem José da Silva, metáfora do povo (ou do próprio teatro brasileiro), sempre pobre e magro, que durante toda a encenação só quer comer.

Para contar a história de José, o Núcleo utiliza-se de outra história: a de um grupo de teatro, às vésperas da estréia, que enfrenta seus inúmeros problemas para botar seu espetáculo no palco. Augusto, o ator, depara-se com a pesquisa e as descobertas na construção de sua personagem: o pobre José da Silva. Assim tem a oportunidade de explorar um pouco do que foi feito durante a curta história do teatro nacional.

Dessa forma, o Núcleo Descobrir Teatro experimenta uma viagem irresponsável (com muita responsabilidade) pelo Teatro Brasileiro e, da sua maneira, tenta revolucionar o que feito, discutindo as relações de poder (opressor / oprimido), política, sociedade, desigualdade, tecnologia, comunicação e principalmente o ser humano, através de personagens e obras que, de certa forma, marcaram a história do nosso teatro.

Direção: Carlos Doles

Adaptação: Atores do Núcleo

Descobrir Teatro

Cenas Complementares e

Adapatação Final: Carlos Doles

Organização e Proposta de Figurinos:

Fernanda Brito, Stephany Nayara e

Talila Rosa

Alessandro Marconi

Ana Fontes

Ana Furlanes

Aruan Aleixo

Carol Vieira
Fernanda Biito

Guilherme Miralha

Jéssica Lusia

Julian Camargo

Kássia Komauer

\section{ELENCO}

Leon Lopes

Lucas Bueno

Mariana Peres

Michel Rodrigues
Noraah Audi

Stephany Nayara

Talita Rosa 


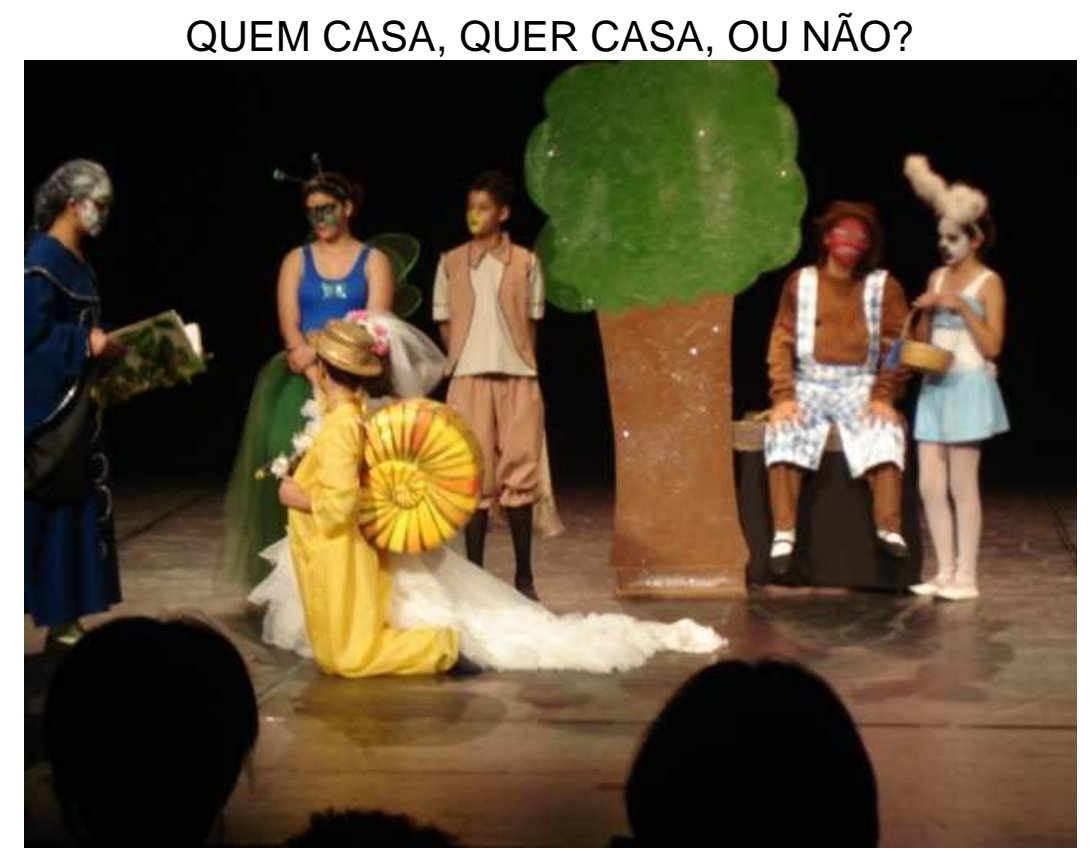

Autor; Tatiana Belinky

Grupo: Cia. Teatral Quatro Cantos de Quadra

Escolas: EMEF "João Inácio Soares" e "EE de Quadra"

Cidade: Quadra

Do grupo teatral Quatro Cantos. Basicamente, reestruturou o espetáculo já apresentado na edição anterior seguindo as orientações que foram propostas pela comissão. Visivelmente, o grupo estabelece uma grande relação com a cidade e toda a comunidade sendo que lá existe apenas uma escola municipal e uma estadual. Ainda existe uma grade deficiência nos atores, falta um trabalho com jogos. Durante o debate, a comissão se coloca favorável ao trabalho que vem sendo desenvolvido na cidade e coloca mais sugestões para o desenvolvimento do grupo. 


\section{RELEASE}

Uma história repleta de muita confusão e diversão. Assim pode dizer sobre a história de Lelé e Mujim. Ela uma lesma dengosa e romântica, que procura casamento. Ele, um caramujo resmungão e convencido, mas que também procura uma noiva. Quando se conhecem resolvem casar-se... Mas será que esse casamento terá um final feliz?

\section{FICHA TÉCNICA E ARTÍSTICA}

Direção: Benemairi Sulivan

Assistente: Luciana Mosconi Rodrigues

Maquiagem: Ana Carla Messias Barbosa

Contra-Regragem: Willian Alísson Lemes, Guilherme Dias Nunes e Ricardo Aparecido Justino

\section{ELENCO}

Ingridy Ivis Gomes da Silva

João Guilherme Pires

Daniel Barbosa Jr.

Marcos Augusto Gonçalves

Ricardo Camargo de Lima

Rúbia Quadros Pinheiro

Tainara do Nascimento Barbosa

Paloma Lopes

Fernanda Patrícia C. Souza 


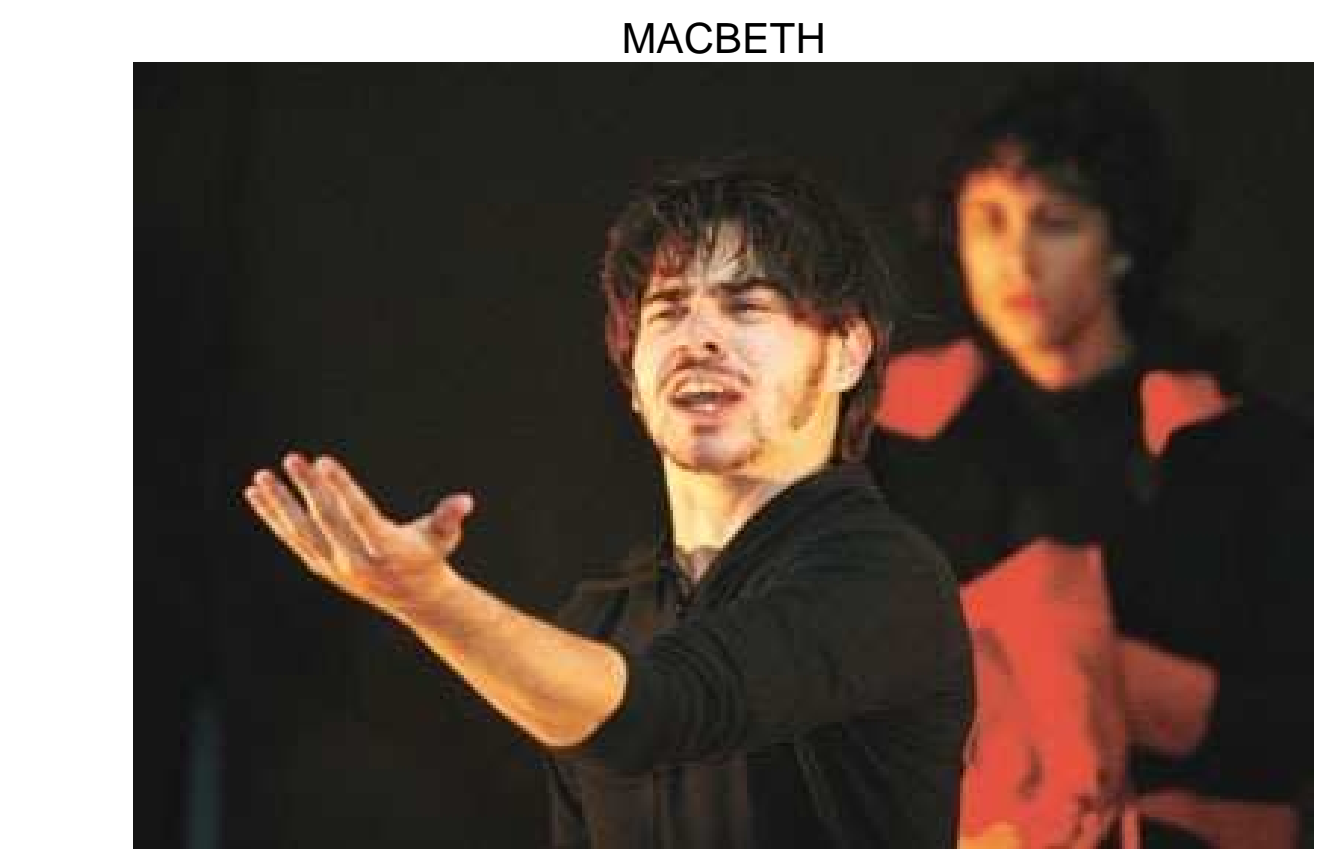

Autor: Baseado na Obra de Willian Shakespeare, adaptação de Fábio Jurera Grupo: Grupo Teatral Tapanaraca Mutatis Mutandis

Escola: Escola Estadual Professor Abílio Fontes

Cidade: Itapetininga

Do grupo Tapanaraca, da Cidade de Itapetininga, o espetáculo vem com grande acerto de figurino, sonoplastia, uma cenografia que estabelece total relação com o espetáculo e uma interpretação dos atores muito bem definida. A direção foi certeira, não procurou inventar, mas sim dar o formato do grupo para o espetáculo. Durante o debate, a Comissão Julgadora se colocou satisfeita e ao mesmo tempo empolgada com o espetáculo. 


\section{RELEASE}

Ao voltarem de uma batalha vitoriosa, os valentes generais Macbeth e Banquo encontram no caminho três bruxas que lhes fazem as seguintes profecias: que um dia Macbeth se tornaria réu e Banquo seria o pai de uma linhagem de reis. Instigado por sua ambiciosa esposa, Macbeth mata o Rei Duncan, que estava hospedado em seu castelo, e faz com que a culpa recaia sobre o filho do rei, Malcolm. Por ser o próximo na linha de sucessão, Macbeth é coroado. A partir daí, ele passa a eliminar todos aqueles que representam uma ameaça ao seu poder, a começar por ser "melhor amigo", Banquo. Protegido, por uma nova profecia, que o torna imbatível, Macbeth aterroriza a todos, até ver-se cercado por forças invasoras, lideradas por Malcolm e Macduff, que vieram para re-estabelecer a ordem e se necessário, acabar com o tirano.

\section{FICHA TÉCNICA E ARTÍSTICA}

Diretor: Fábio Jurera

Trilha Sonora Original: Banda

Buneliox

Operação de Som: Fábio Jurera Iluminação: Lucy Villar
Operação de Luz: Lucy Villar

Figurino: O Grupo

Maquiagem: O Grupo

Cenografia: O Grupo

Técnica: Juju Kin e Ana Dias ELENCO
Elis Regina

Andréa Vaz

Letícia Jordão

Antônio Pauis

Jlionny Medeiros

Henrique Ayur
Rafael Rodrigues

Aithut Ferrarezi

Anderson Thiago

Felipe Almeida

Marckos Phellype

Diego Pereira 


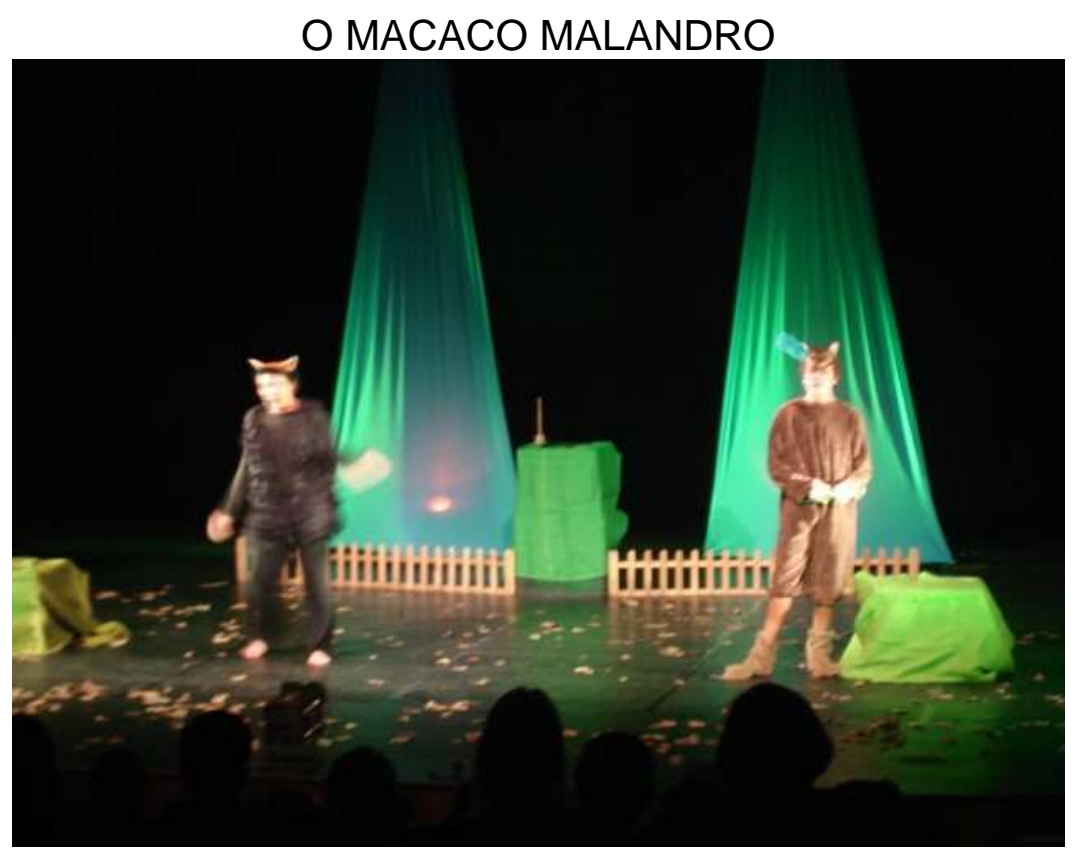

Autor: Tatiana Belinky

Grupo: Grupo de Teatro Amador de Pereiras

Escola: E. E. Ver Egildo Paschoalucci

Cidade: Pereiras

Do Grupo de Teatro Amador de Pereiras, uma montagem um pouco ingênua no que diz respeito à estética teatral, embora devamos levar em consideração o processo de trabalho. Percebe-se que o espetáculo tinha um acabamento bem finalizado, mas que o figurino deixava as crianças um pouco em dúvida com relação às personagens. Durante o debate, sugestões foram dadas principalmente no que diz respeito ao processo de trabalho. 


\section{RELEASE}

Peça de Tatiane Belinky, contando com três personagens, que interagem no palco: a Raposa, o Lobo e o Macaco Juiz. O texto se desenvolve na luta entre a raposa e o lobo que disputam quem fica com o queijo que acharam, contado com a participação do macaco juiz que acaba enrolando os dois.

O Macaco Malandro é uma comédia com cenas hilariantes muito bem interpretadas pelos atores em cena.

FICHA TÉCNICA E ARTÍSTICA

Diretor: André Luiz de Camargo

\section{ELENCO}

Pablo Martins Corrêa

Antônio Roberto Pereira da Rocha

Jéferson Camargo Moreira

Everton Camargo Moreira

Isabela Cristine Faria Moreira. 


\section{NEM TUDO É O QUE PARECE}

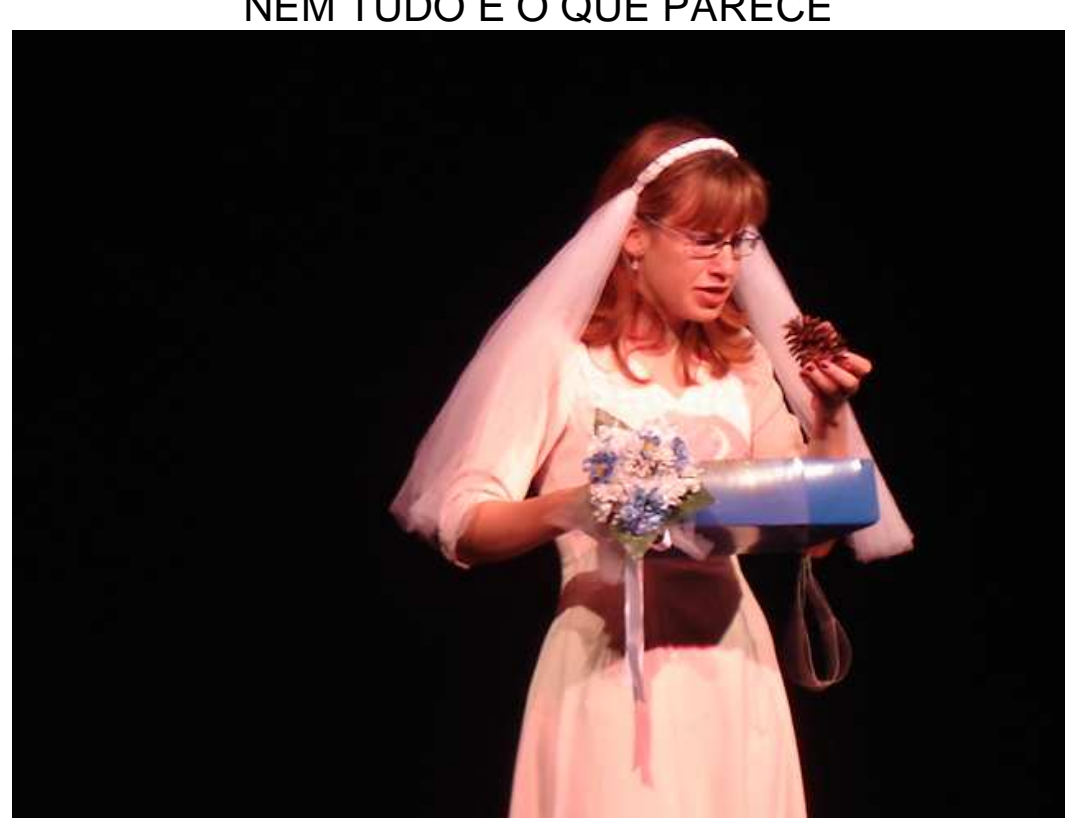

Autor: Gustavo César Pereira

Grupo: Grupo de Comédia Quasilá

Escola: Escola Estadual Maria Cecília Ferraz de Freitas

Cidade: Marília

Da cidade de Marília, do grupo Quasilá. Um grande equívoco e uma sucessão de erros foram apresentados no palco. Os atores e direção, embora tenham tido uma grande vontade, perderam-se na estruturação do espetáculo que chegou, em muitos minutos, a ficar insuportável. A falta de um processo elaborado também foi visível para quem analisava. Durante o debate, a comissão se mostrou preocupada com o espetáculo, tentando apontar caminhos, mas o grupo parecia não querer absorver muito as informações que ali eram dadas. 


\section{RELEASE}

O espetáculo é uma tragicomédia bem irreverente, trata de um tema atual dentro de um contexto eminentemente maluco. Nem Tudo É O Que Parece retrata a história de um grupo de artistas que busca o sucesso e a fama. Nesta trajetória artística, surge a oportunidade de nossos protagonistas atuarem na peça de um diretor bem famoso. $\mathrm{Na}$ apresentação, uma das personagens sofre um ataque terrorista e o que era para ser um espetáculo teatral acaba virando uma grande tragédia. Sendo assim, paira no ar; quem foi o feitor do crime?

FICHA TÉCNICA E ARTÍSTICA

Direção: Gustavo César Pereira

\section{ELENCO}

Bianca de Luccas Covo

Diego Granciere Sparapane

Érick Lucas Soares

Patrícia Santos

Matheus Souza Espejo

Kleiton Lolí

Gustavo César Pereira 


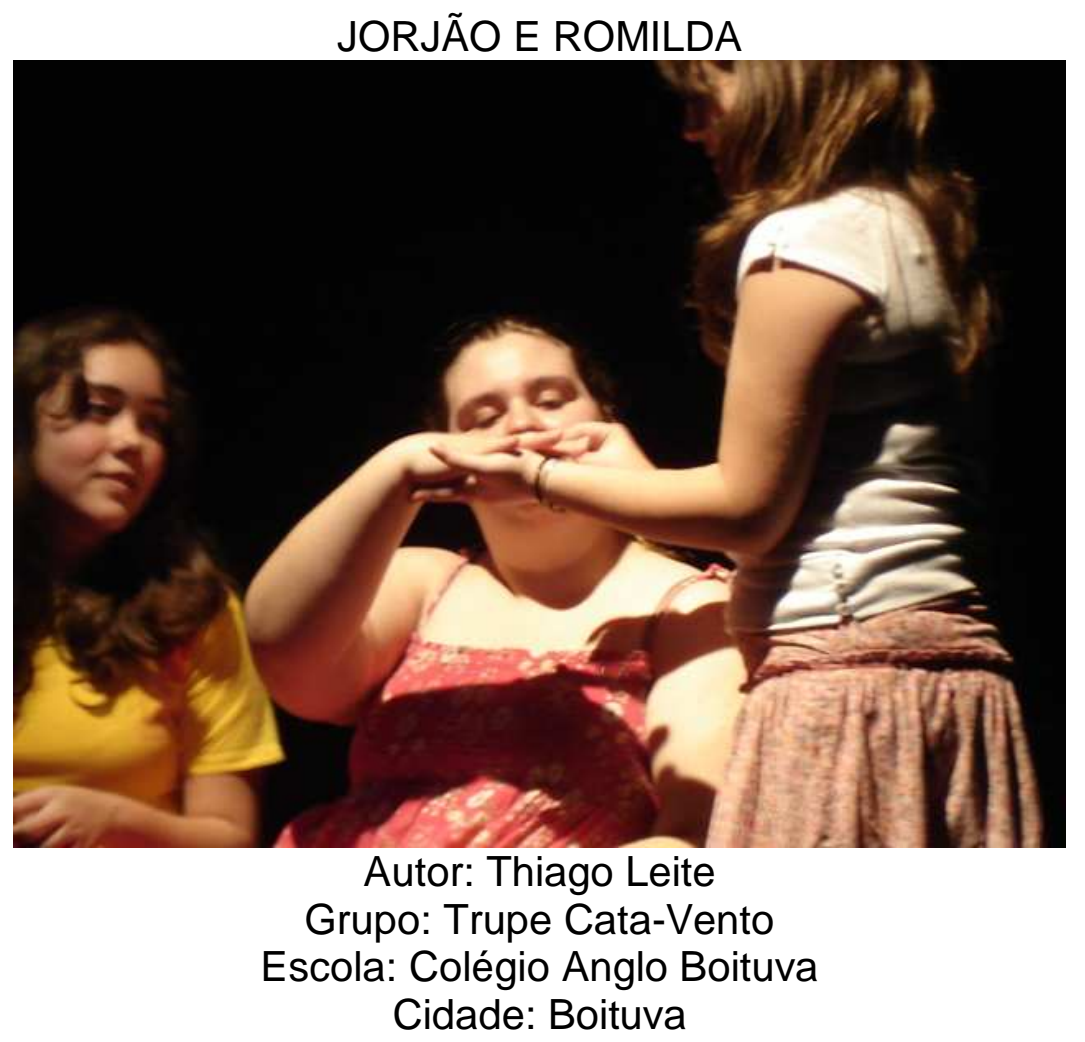

De maneira simples e apaixonante, a história se desenrolou num grande jogo teatral em que as crianças tinham propriedades naquilo que estavam fazendo, era nítida a despreocupação com a interpretação, mas o comprometimento com o fazer teatral de tal maneira que se percebia que 0 jogo estava implícito. Durante o debate, os jurados se colocaram favorável ao espetáculo, mas colocam a questão de que talvez o espetáculo deva ser apresentado em lugares mais alternativos e não em palco italiano. 


\section{RELEASE}

Jorjão, um feirante. Romilda, a filha do Coronel mais afamado e carrancudo da cidade. Esses dois personagens, apaixonados desde crianças, tentam ficar juntos, mas o preconceito do pai tenta por fim ao romance. Assim, o casal, ajudado por seus amigos, tenta variadas artimanhas para se encontrar, mas são descobertos pelo Coronel. Desacreditados e entristecidos, o romance parece chegar ao fim, entretanto um grave acontecimento ainda pode dar uma reviravolta na história. Partindo da composição de imagens corporais, utilizamos apenas adereços cênicos para construir o ambiente, tomando as vivências e experiências de cada aluno/ator no processo de criação, damos à narrativa uma agilidade de ação e um prazer magistral que nasce a partir do jogo entre ator, músicas e texto durante a evolução do espetáculo. O jogo premia todas as ações e imagens estabelecidas. A partir dele o processo de criação foi se desenrolando, buscando o espontâneo no ato de improvisar. Assim, o trabalho do coletivo, em que alunos e orientador criam juntos e se envolvem nessa criação acaba por transbordar para o público que é convidado a degustar esse grande Jogo Teatral.

\section{Direção: Thiago Leite} Sonoplastia: Thiago Leite Iluminação: Thiago Leite Operadores de Luz: Elton Pinheiro e Fernando Casalunga Cenografia: Trupe Cata Vento
FICHA TÉCNICA E ARTÍSTICA

Maquiagem: Trupe Cata-Vento

Figurinos: Trupe Cata-Vento Contra-Regragem: Alex Dias Alves, Glória Ventura, Marie Terashima Yoshizawa, Osvaldo Ferreira, Mônica Magnano e Sandra Almeida
Jonatas Fontes Carvalho Ana Laura Holtz de Almeida Rosa Matheus Rodrigues de Oliveira Maria Fernanda Barbosa de Oliveira Reinaldo Alves Filho

\section{ELENCO}

Laura Campos Santos Stephanie Cassemiro Vanessa Fernanda Brancaccio Letícia Yumi Girdosek Letícia Siqueira Sene Letícia Buzacarini Alvim Giovana Meireles Geovana Costa Camargo
Gabriella Fabri Chagas dos Santos

Gabriela Aquino Lobato Bruna da Rocha Carvalho Costa Anyara Paula Leite Ana Virgínia Scaglioni Viana 


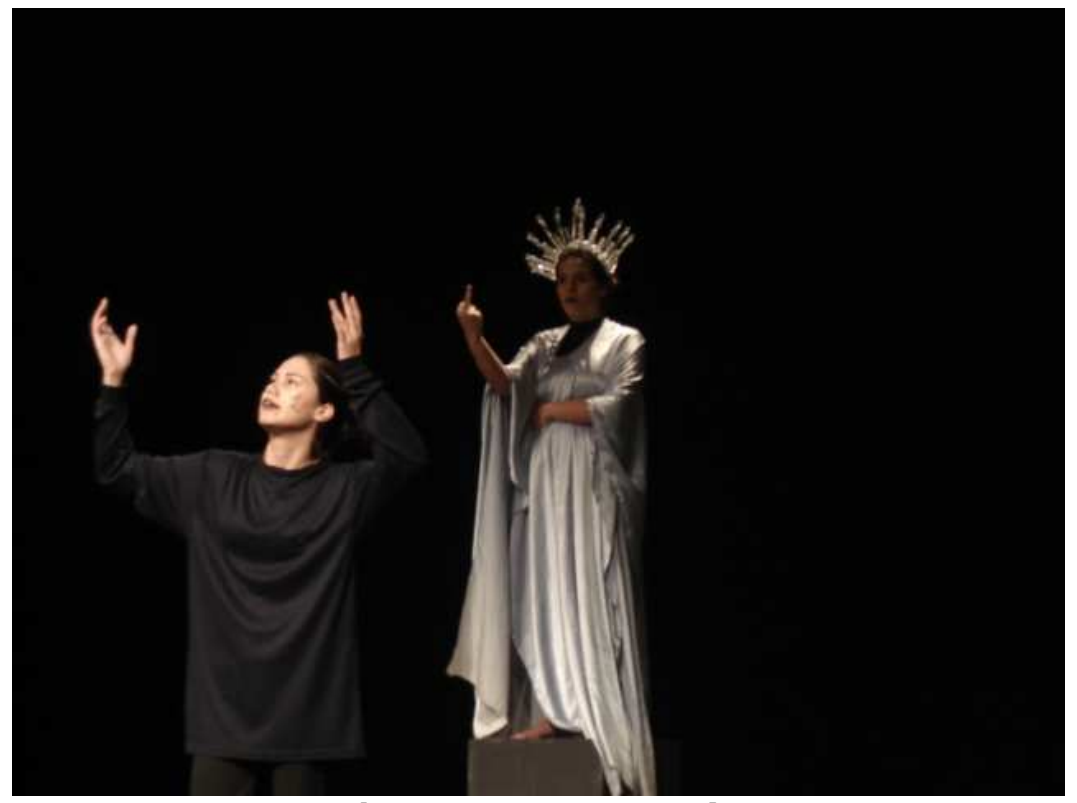

Autor: Millôr Fernandes e Flávio Rangel

Grupo: Cia Teatral Quatro Cantos

Escola: EMFMEF João Inácio Soares e EE de Quadra

Cidade: Quadra

Não parecia que era a mesma direção do infantil que eles apresentaram nessa edição. O espetáculo, que emocionou a platéia, tinha seu jeito simples e peculiar e teve grandes acertos na simplicidade do figurino e na utilização do espaço cênico. A direção mostrou estar trilhando um caminho de maturação junto o grupo. A comissão julgadora se mostra surpresa com o trabalho ali apresentado e ressalta a importância desse grupo no contexto do festival estudantil. 


\section{RELEASE}

A peça narra a história de personagens que lutaram a favor e contra a Liberdade, desde de os tempos de Sócrates até os tempos atuais. E nos faz pensar da seguinte forma; até onde vai a nossa Liberdade e quando ela se torna Libertinagem?

\section{FICHA TÉCNICA E ARTÍSTICA}

Direção: Benemari Sulivam

Assistente: Luciana Mosconi Robrigues

Maquiagem: Thamires Elizabete da Silveira, Thais Aparecida Soares e Samanta de Barros Oliveira

Contra-Regragem: Guilherme Dias Nunes e Ricardo Aparecido Justino

\section{ELENCO}

Ana Carolina da Silva Gonçalves

Ana Carla Messias da Silva

Caroline Soares de Souza

Daniela Siqueira Lobo

Daniel Barbosa Júnior

Edivana Mendes Vieira

Isabela Hanfe Bimbatte

Juliano Souza Pereira
Letícia Camargo

Mariucha Cáceres Delsi

Nayara Pedroso Gonçalves

Valéria Gomes do Carmo

Vânia Aparecida Antunes

Vanessa Soares

Willian Alisson Lemes 


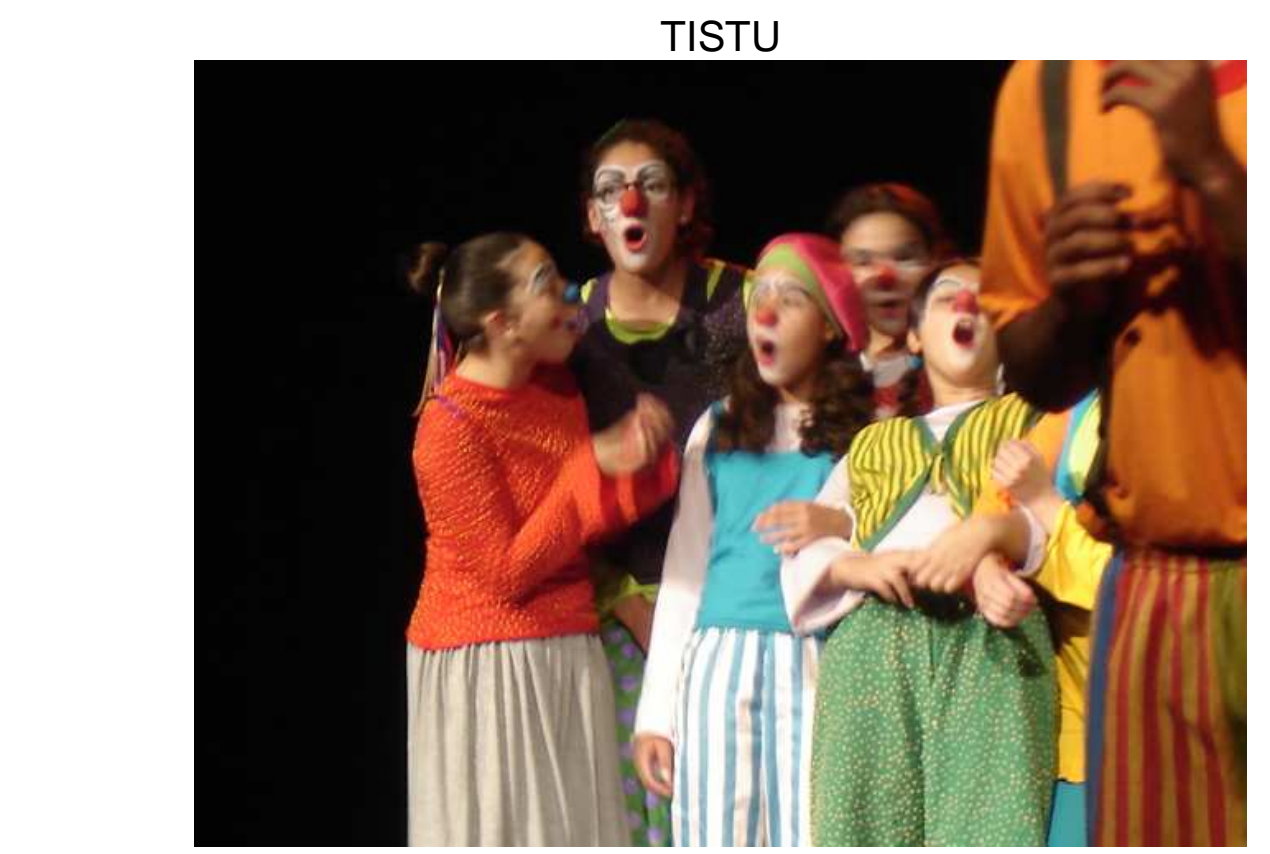

Autor: Adaptação do livro Tistu, O menino do dedo verde de Maurice Druon. Grupo: Cia de Teatro Uta

Escola: E. E. Dr. Afonso Vergueiro.

Cidade: Salto de Pirapora

Da cidade de Salto de Pirapora, o Grupo Uta trouxe um espetáculo que levou a platéia a um mundo de encantos. Bonecos e adereços, particularmente, deram um toque especial ao espetáculo. A direção foi assertiva, apenas a música, que era ao vivo, sobressaiu um pouco ao espetáculo. Um espetáculo delicado, colorido, emocionante que nos faz refletir o que é um grupo que vem se desenvolvendo através do festival estudantil, baseando-se nas orientações dos mestres que ali estão. A Comissão julgadora se colocou muito técnica sobre o espetáculo e ressaltou a positividade dos acertos. 


\section{RELEASE}

Tistu é uma menina feliz que vive ao lado do Senhor Papai e Dona Mamãe na Casa-que-brilha, porém completou oito anos e precisa ir para a escola, pois seu pai deseja que no futuro ela o substitua na direção da fábrica de canhões, em Mirapólvora, assim como ele substituíra o Sr. Vovô,

$\mathrm{Na}$ escola, ela não consegue aprender, então a família assume a responsabilidade por sua aprendizagem. Com Senhor Bigode passa a ter lições de jardinagem, a Srta. Trovoada the ensina o que é ordem e a miséria e com a Dra. Milmales aprende sobre a saúde. Embora tudo pareça correr bem, Tistu descobre que tem o dedo verde e isso vai causar muita confusão.

Direção: Jane Kastorsky

Maquiagem: Marcelo Saturno

Cabelo e Relações Públicas: Rode

Barrabela

Sonoplastia: Cafu e Rosângela Souza

Iluminação, Operador de Luze

Filmagem: Felipe Nóris

Figurino: Jane Kastorsky e Elenco

Confecção do Figurino: Áurea

Aparecida de Almeida

Daniellen Almeida

Eliza Santana

Évelin Ferraz

Kamila Kleye

Kelly Dias

Leandro Freitas
FICHA TÉCNICA E ARTÍSTICA

Cenografia: Donrival de Souza

Concepção e Manipulação de

Bonecos: Eliane Ribeiro e Paola

Bertolini

Preparação Vocal: Bia Beldi

Técnicas Circenses: Rômulo Guerra e Vinícius Magueta

Preparação Física: Sueli Anhaia

Expressão Corporal e Coreografia:

Mídia Lopez

ELENCO

Natalia Souza

Paola Santos

Reinaldo Cruz

Rosângela Souza

Soraya Jasmineiro

Zeca Santos 


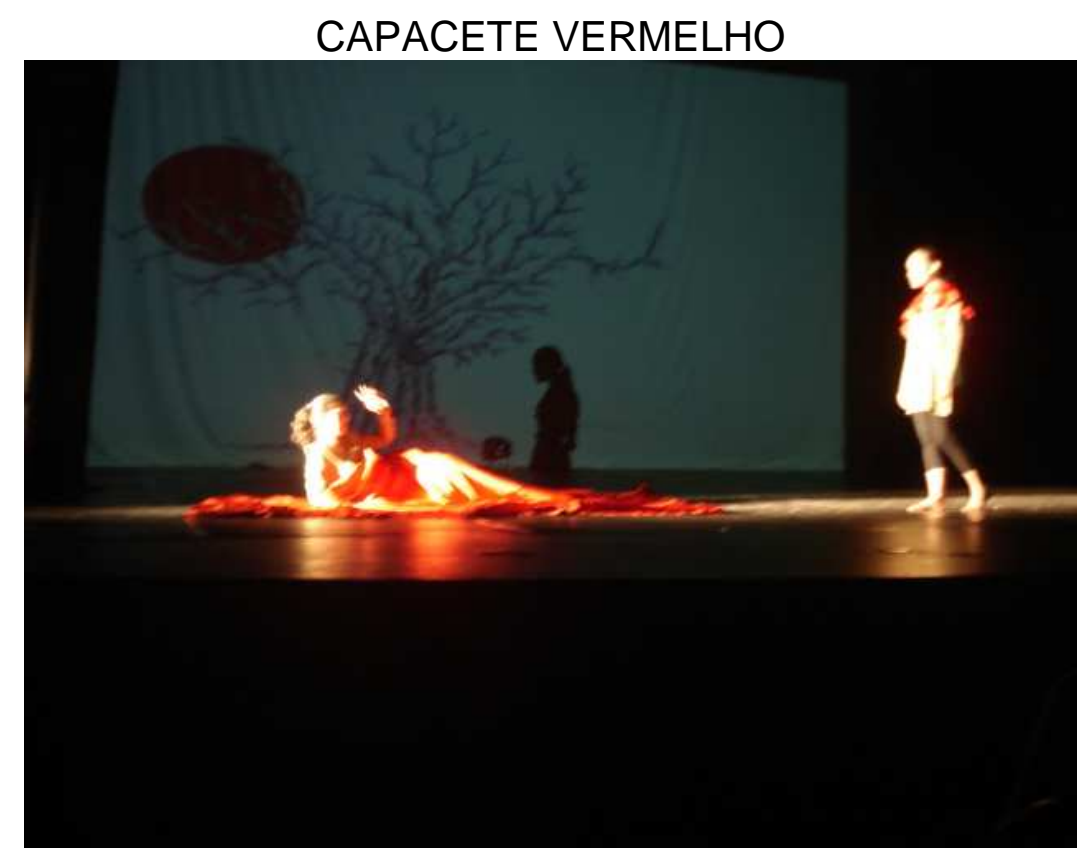

Grupo: Alcalinos

Escola: Escola Técnica de Arte e Comunicação - ETAC

Cidade: Sorocaba

Na tentativa de uma nova linguagem, o grupo Alcalinos, da cidade de Sorocaba, equivocou-se na montagem. O espetáculo não chegou a acontecer, uma mistura de imagens e o uso da multimídia chegou a atrapalha, pois não tinha uma pesquisa fundamentada para a experimentação cênica a que se propunha. A comissão julgadora ressalta que uma pesquisa mais elaborada deve ser feita para a realização do trabalho e se mostra desconfortável. 


\section{RELEASE}

Capacete Vermelho aborda a clássica história de Chapeuzinho Vermelho como imitação crítica do cotidiano, transformando os elementos e as personagens do conto em metáforas da sociedade. O grupo utiliza de recursos multimidiáticos e instrumentos musicais para compor a experimentação cênica. Assim o espetáculo elege uma comédia inconformada.

Texto Cênico: Ramon Ayres

\section{FICHA TÉCNICA E ARTÍSTICA}

Encenador/Instrutor: Ramon Ayres

Sonoplastia: Thiago e Vivian

Músicos: Thiago e Vivian

Operador de Som: Stefany Cristiny

Iluminação: Bruna Salatini

Operadora de Luz: Bruna Salatini

Áudio-Visual: Caroline, Danila o Michel

Operadores de Áudio - Visual: Fernanda Brito e Ramon Ayres

Figurino: Ramon Ayres

Preparação Corporal: Melany Kerny

Camila Macedo

ELENCO

Carol Campos

Michel Rodrigo

Danila Gonçalves

Rosi Brisola

Eduardo Ribeiro

Samuel Silva

Gladson Reis

Thiago Carpegiani

Vivian 


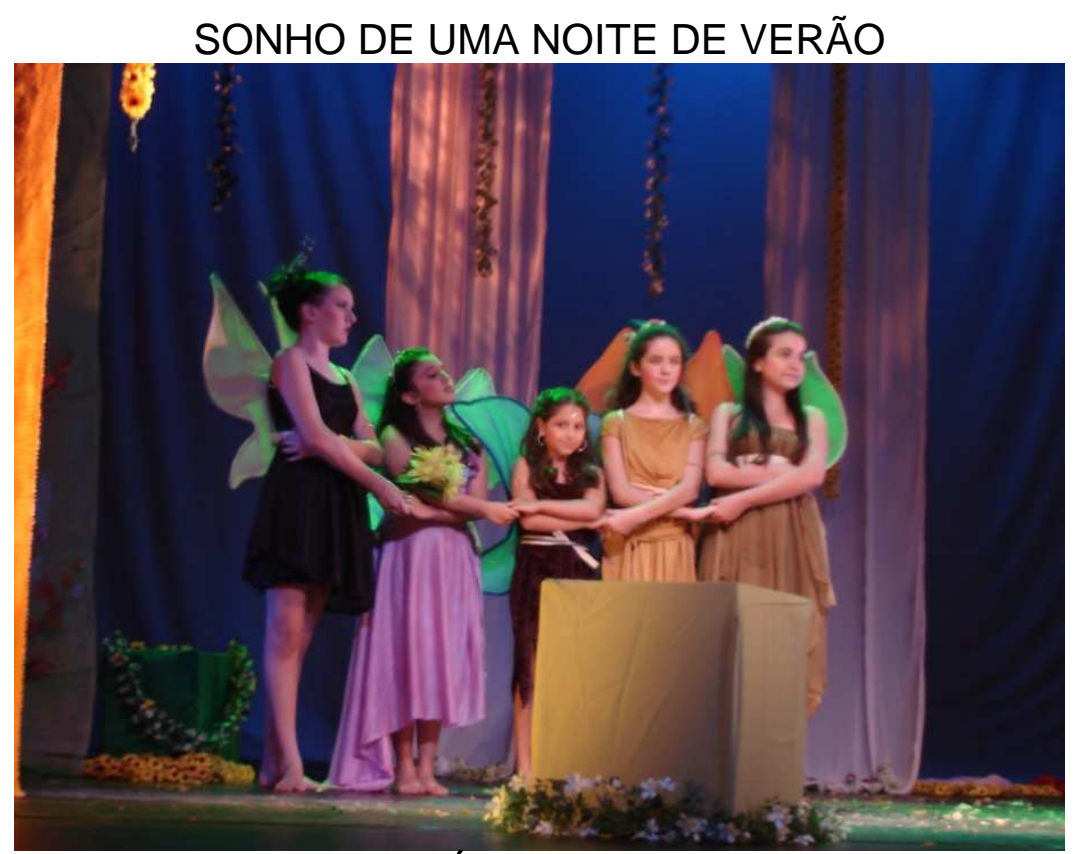

Autor: Adaptação de Érika Bodstein e Valéria Marchi Grupo: Grupo de Teatro Cilzinho Escola: Colégio Imperatriz Leopoldina Cidade: São Paulo

O Grupo apresentou o espetáculo com grande número de erros, em que o figurino e cenário engoliam os atores, que não se sentiam nem um pouco confortáveis com o que estavam ali apresentando. O espetáculo monótono e que não chegou até as crianças. Durante o debate, a comissão julgadora aponta caminhos e, como já em edições anteriores, coloca para o grupo a importância de um trabalho mais livre com jogos e apropriado para a idade dos jovens alunos atores. 


\section{RELEASE}

No Colégio Imperatriz Leopoldina existe um trabalho orgânico de aprendizado teatral, sempre nos remetendo ao diálogo entre as artes e as diferentes culturas. O Grupo Teatral Cilzinho, criado especialmente para jovens pré-adolescentes, cursando entre a $5^{\mathrm{a}}$ e $7^{\mathrm{a}}$ séries do Ensino Fundamental, é uma oportunidade criada para aprender, com textos mais acessíveis, o fazer teatral.

O texto adaptado traz a versão clássica de Shakespeare e as personagens, envolvidas no clima de sonho, trazem aos alunos a primeira oportunidade para deixarem as portas da escola e almejarem sonhos maiores.

FICHA TÉCNICA E ARTÍSTICA

Adaptação do Texto, Direção, Figurino, Trilha Sonora e Operação do Som: Valéria Marchi

Adaptação do Texto, Assistência de Direção, Iluminação, Projeto Cenografia e Operação de Luz: Erika Bodstein

Monitoria: Evlyn Beck e Norma Burguer

$$
\text { ELENCO }
$$

Adriana Alves da Rosa

Ana Luiza N. Carvalho Andrezza Pizzoli Ramos

Bárbara Perrupato

Duarte

Bruna de Aguiar Vanucci

Camila Cortina Barbosa

Lima

Carolina Gianella

Carolina Mota Júlio

Carolina Sacchi Martins

Caroline Felizardo

Fagundes
Caroliny Chang

Rodrigues

Felipe Minhoni Delia

Posta

Fernanda de Almeida

Testa

Gianluca Rossiní

Fonseca

Giovane Ortega Ribeiro

Giulía Magrini Rett

João Pedro N. Carvalho Julie Moreira Hannes

Lays Carvalho $\mathrm{C}$ de Melo
Loreena Luiza Kogawa

Marina Lima Lopes

Mariana Alves Balsan

Natália Rocha Ferranda

Paloma Schulz

Magalhães

João Paulo Vianna

Rafael Toshio Rama

Rafaela Torneri

Raphaela Jana Marioni

Victor Garcia Palácios

Vitória Caldeira do

Nascimento 


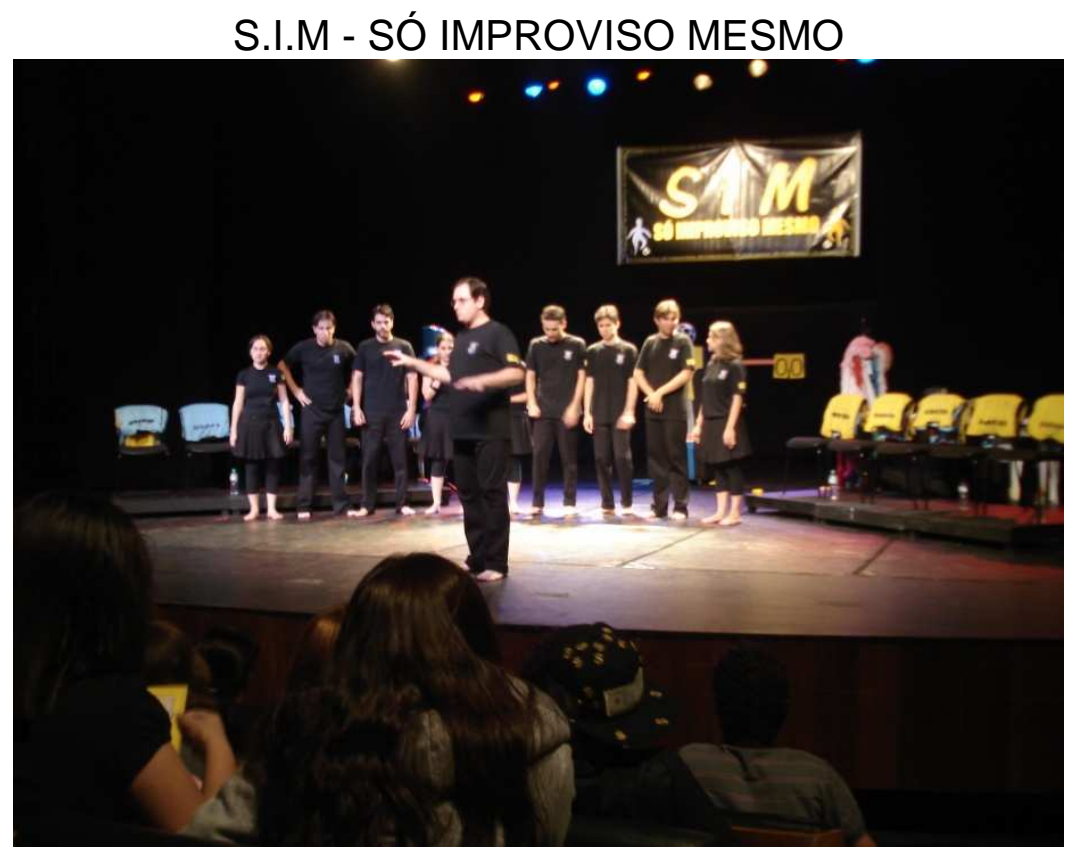

Grupo: S.I.M - Só Improviso Mesmo

Escola: Fundação das Artes de São Caetano do Sul Cidade: São Caetano do Sul - SP

Realmente não podemos considerar como um espetáculo. Através de improvisos, a platéia foi levada a algumas brincadeiras e jogos. Exercícios puramente de aulas de teatro. Durante o debate, a comissão julgadora contestou a estrutura do espetáculo e sugeriu que eles repensem quanto a levar isso para o palco como um espetáculo de teatro. 


\section{RELEASE}

Um espetáculo em quede o improviso ganha sua verdadeira importância e 0 ator demonstra suas técnicas e conhecimentos diante do público, errando e acertando com ele.

O espetáculo funciona seguindo os moldes de um jogo de futebol: dois times disputarão em favor de um mesmo objetivo, o teatro. Um time será representado pela cor Amarela e outro pela cor Azul e é a platéia quem sorteia essa divisão. Cada time cria seu grito de guerra e o apresenta, começa então a pontuação, o que se segue são jogos determinados pelo juiz que serão feitos pelos dois times; aquele que desenvolver melhor o jogo dentro das regras propostas ou aquele que apresentar uma cena mais interessante ou simplesmente aquele que a platéia escolher, leva o ponto. Para votar, o público receberá na entrada o programa do espetáculo que de um lado é amarelo e do outro azul, desta forma, além de conter as informações técnicas do jogo, este programa também servirá de "placa" para votação,

A partida é dividida em dois tempos de 30 minutos com um intervalo de 15 minutos em que os jogadores devolvem os coletes com as cores e se tornam um grande time, apresentando jogos rápidos de intervalo.

No segundo tempo, a platéia divide novamente os times, os pontos permanecem, mas as pessoas mudam ou não de cor.

São feitos novos jogos da mesma forma que o tempo anterior. Ao final da partida é anunciado um vencedor, os jogadores então devolvem novamente os coletes e se despedem do público. Uma partida nunca é igual à outra.

\section{FICHA TÉCNICA E ARTÍSTICA}

Autor: Criação Coletiva - Improvisação Operador de Luz: Sérgio de Azevedo

Arbitra/Diretora: Vanessa Senatori Figurino: Maira Paris

Auxiliar de Árbitro: Melissa Aguiar

\section{ELENCO}

Cenário: Rodrigo Zappa

André Rinaldi

Felipe Scalzaretto

George Vilches

Kleber Parra

Lívia Ferreira

Maíra Paris

Mayara Cristina

Rafael Soares

Rodrigo Zappa

Thais Gíacon 
PREMIAÇÃO CATEGORIA INFANTIL

\begin{tabular}{|c|c|c|c|c|c|c|}
\hline & $\begin{array}{l}\text { A LENDA } \\
\text { DE PLUFT }\end{array}$ & $\begin{array}{c}\text { QUEM } \\
\text { CASA, } \\
\text { QUER } \\
\text { CASA, OU } \\
\text { NẤ? }\end{array}$ & $\begin{array}{l}\text { O MACACO } \\
\text { MALANDRO }\end{array}$ & $\begin{array}{l}\text { JORJÃO E } \\
\text { ROMILDA }\end{array}$ & TISTU & $\begin{array}{l}\text { SONHO DE UMA } \\
\text { NOITE DE VERÃO }\end{array}$ \\
\hline $\begin{array}{l}\text { COADJUVANTE } \\
\text { MASCULINO }\end{array}$ & & & & & $\begin{array}{l}\text { ZECA } \\
\text { CAMPOS }\end{array}$ & \\
\hline $\begin{array}{l}\text { COADJUVANTE } \\
\text { FEMININO }\end{array}$ & & & & & KELLY DIAS & \\
\hline CENOGRAFIA & & & & & & ÉRIKA BODSTEIN \\
\hline ILUMINAÇÃO & & & & & & ÉRIKA BODSTEIN \\
\hline FIGURINO & & & & O GRUPO & & \\
\hline MAQUIAGEM & & & & & $\begin{array}{l}\text { MARCELO } \\
\text { SATURNO }\end{array}$ & \\
\hline SONOPLASTIA & & & & & $\begin{array}{c}\text { CAFÚ E } \\
\text { ROSANGELA }\end{array}$ & \\
\hline DIREÇÃO & & & & & $\begin{array}{l}\text { JANE } \\
\text { KASTORSKY }\end{array}$ & \\
\hline MELHOR ATOR & & $\begin{array}{c}\text { MARCOS } \\
\text { AUGUSTO } \\
\text { GONÇALVES }\end{array}$ & & & & \\
\hline MELHOR ATRIZ & & & & & $\begin{array}{l}\text { EVELIN } \\
\text { FERRAZ }\end{array}$ & \\
\hline DRAMATURGIA & & & & $\begin{array}{l}\text { THIAGO } \\
\text { LEITE }\end{array}$ & & \\
\hline $\begin{array}{l}\text { MELHOR ESPETÁCULO } \\
\text { JURI POPULAR }\end{array}$ & & & $\begin{array}{l}\text { O MACACO } \\
\text { MALANDRO }\end{array}$ & & & \\
\hline $\begin{array}{l}\text { MELHOR } \\
\text { ESPETÁCULO }\end{array}$ & & & & & TISTU & \\
\hline $\begin{array}{l}2^{\circ} \text { MELHOR } \\
\text { ESPETÁCULO }\end{array}$ & & & & $\begin{array}{l}\text { JORJÃO E } \\
\text { ROMILDA }\end{array}$ & & \\
\hline
\end{tabular}


PREMIAÇÃO CATEGORIA ADULTO

\begin{tabular}{|c|c|c|c|c|c|c|}
\hline & REVOLUÇÃo & MACBETH & $\begin{array}{c}\text { NEM TUDO É } \\
\text { O QUE } \\
\text { PARECE }\end{array}$ & $\begin{array}{l}\text { LIBERDADE, } \\
\text { LIBERDADE }\end{array}$ & $\begin{array}{l}\text { CAPACETE } \\
\text { VERMELHO }\end{array}$ & $\begin{array}{c}\text { S.I.M. SÓ } \\
\text { IMPROVISO } \\
\text { MESMO }\end{array}$ \\
\hline $\begin{array}{l}\text { COADJUVAN } \\
\text { TE } \\
\text { MASCULINO }\end{array}$ & $\begin{array}{l}\text { MICHEL } \\
\text { RODRIGUES }\end{array}$ & & & & & \\
\hline $\begin{array}{l}\text { COADJUVAN } \\
\text { TE FEMININO }\end{array}$ & & & & $\begin{array}{l}\text { EDIVANA } \\
\text { MENDES }\end{array}$ & & \\
\hline CENOGRAFIA & & O GRUPO & & & & \\
\hline ILUMINAÇÃO & & LUCY VILLAR & & & & \\
\hline FIGURINO & & O GRUPO & & & & \\
\hline MAQUIAGEM & & O GRUPO & & & & \\
\hline $\begin{array}{l}\text { SONOPLASTI } \\
\text { A }\end{array}$ & $\begin{array}{l}\text { CARLOS } \\
\text { DOLES }\end{array}$ & & & & & \\
\hline DIREÇÃO & & $\begin{array}{c}\text { FABIO } \\
\text { JURERA }\end{array}$ & & & & \\
\hline $\begin{array}{l}\text { MELHOR } \\
\text { ATOR }\end{array}$ & $\begin{array}{l}\text { JULIAN } \\
\text { CAMARGO }\end{array}$ & & & & & \\
\hline $\begin{array}{l}\text { MELHOR } \\
\text { ATRIZ }\end{array}$ & $\begin{array}{c}\text { MARIANA } \\
\text { PEREZ }\end{array}$ & & & & & \\
\hline $\begin{array}{l}\text { PESQUISA DE } \\
\text { DRAMATURGI } \\
\text { A }\end{array}$ & $\begin{array}{c}\text { NÚCLEO } \\
\text { DESCOBRIR } \\
\text { TEATRO }\end{array}$ & & & & & \\
\hline $\begin{array}{l}\text { MELHOR } \\
\text { ESPEUACULO JURI } \\
\text { POPLAR }\end{array}$ & & & & $\begin{array}{l}\text { LIBERDADE, } \\
\text { LIBERDADE }\end{array}$ & & \\
\hline $\begin{array}{l}\text { 20 MELHOR }^{\circ} \text { MSETÁCULO } \\
\text { ESPE }\end{array}$ & REVOLUÇÃo & & & & & \\
\hline $\begin{array}{l}\text { MELHOR } \\
\text { ESPETÁCULO }\end{array}$ & & MACBETH & & & & \\
\hline
\end{tabular}




\section{CAPÍTULO III}

\section{O FESTIVAL E A FORMAÇÃO DOS GRUPOS NAS ESCOLAS}

A identidade dos grupos que trafegam pelos festivais não difere muito uns dos outros pelo que vem sendo observado em um aspecto geral.

Os grupos começam a se formar, na maioria das vezes, por interesses de alunos, ex- alunos que queiram participar e em alguns casos por interesse dos professores. A escola pública é o lugar em que observamos uma freqüência maior de desenvolvimento desse trabalho.

A cada ano, forma-se grupo com muitos integrantes, mas com o passar do tempo há uma seleção natural, já que muitos alunos não se adaptam às regras criadas pelo próprio grupo, no que diz respeito à pontualidade do horário de ensaios, jogos etc. Então, acabam saindo, só permanece no grupo aqueles que gostam e aceitam as regras determinadas pelo grupo.

Inicialmente, os alunos procuram o teatro como quem procura participar de um time para a prática de esporte ou a fanfarra da escola. Eles querem, na realidade, participar de um grupo, vêm em busca de um convívio social, sem saber o que realmente vão encontrar pela frente. É claro que existem exceções. Já o professor envolvido começa a ter interesse pela inquietação dos alunos, que Ihes é natural. A necessidade de expressar, em outros casos, por isso faz com que os professores sejam procurados pelos alunos que começam a ter interesse pelo assunto. Na maioria das situações, o professor é totalmente autodidata no que se refere ao teatro, geralmente leciona matéria que se distancia das artes cênicas.

Usei como base na minha pesquisa o trabalho desenvolvido, no ensino fundamental e médio, por cinco professores-diretores de grupos de teatro estudantis: Pámela Paz - Grupo Teen de Teatro Santo Agostinho; Jane Kastorsky - Grupo UTA; Thiago Leite, do Grupo Trupe Catavento, do Colégio Anglo Boituva; Fábio Jurera do Grupo Teatral Tapanaraca, de Itapetininga e Valéria de Oliveira - Cia. de Teatro Tal\&Pá da Escola Estadual Professora 
Maria Augusta de Ávila, as quais considerei pessoas referenciais para o que me propus.

Para melhor compreensão do trabalho dos Grupos, torna-se necessário fazer um breve histórico de sua criação e desenvolvimento.

Primeiramente, falarei do Grupo Teen de Teatro Santo Agostinho - que funciona no Colégio Santo Agostinho de São Paulo, colégio de tradição católica espanhola. Nascido na década de 1990, nele, a professora Pámela Lorena Paz desenvolveu um trabalho com um grupo que buscou aliar permanentemente a pesquisa dos fundamentos da linguagem teatral à sedimentação do talento dramático de seus participantes.

O curso consistiu na orientação prática de todas as áreas que envolvem as artes cênicas: Dramatização, Expressão Corporal, Coreografias, Dança, Música, Canto, lluminação, Cenografia, Sonoplastia, Figurino, Técnica Vocal, etc.

Em 2001, o Grupo preparou um espetáculo para crianças escrito por Ronaldo Ciambroni, Adeus Fadas e Bruxas, em homenagem aos esquecidos contos de fadas, com esse espetáculo foi a primeira vez que o grupo saiu da escola e se apresentou no Festival Estudantil de Tatuí, lá ganhou prêmios, mas o mais importante sem dúvida foi a conquista de novos grupos de amigos com os quais travou conhecimento e troca que permanecem até hoje.

Em 2002, realizou a montagem teatral Geração Coca Cola de Ronaldo Ciambroni, sobre a história de jovens dos anos 60, houve pesquisa de músicas, danças e costumes da época. Com esse espetáculo, viajaram até Belo Horizonte para participar do FETO (Festival Estudantil de Teatro), apresentaram-se também no $1^{\circ}$ Festival Sesi de Teatro de Sorocaba, e novos prêmios e novas amizades foram conquistadas.

O sucesso do grupo e os bons resultados obtidos levou-os a enfrentar um novo desafio, colocar em cena uma aula de biologia, em que os personagens percorriam os órgãos de vários sistemas como o digestório, o excretor, o circulatório, o nervoso, aplicando diferentes recursos teatrais a cada órgão que chegavam. Assim foi feita a montagem da peça, em 2003, $A$ 
Incrível Viagem pelo Corpo Humano, de Ivan Lovison, com músicas de Gilberto Andreotti e Gilson Faria já antigos compositores parceiros.

Em 2004, a pedido de vários ex-alunos e após dez anos de existência, fez-se a remontagem do espetáculo teatral Mais quero um asno que me carregue do que cavalo que me derrube, de Carlos Alberto Soffredini, baseado na obra homônima de Gil Vicente. Foi um grande trabalho de releitura e pesquisa com o qual obtiveram algumas premiações nos festivais do SesiSorocaba e Tatuí.

Durante o ano de 2005, trabalharam com um texto de Carlos Queiroz Telles, $A$ Revolta dos Perus o que thes deu a oportunidade de aproximação com textos para crianças com alto valor crítico e de muita responsabilidade na linguagem aplicada.

No ano de 2006, o Colégio completou 75 anos e isso os levou a querer homenageá-lo foi então que resolveram ler muito e estudar a vida do patrono Santo Agostinho. Após muitos ensaios, dedicação, companheirismo e esforço conjunto de professores e alunos nasceu o espetáculo Agostiniando, um coração inquieto, nesse espetáculo com muita música e dança 42 alunos contaram o trajeto da vida desse grande mestre.

Segundo a professora Jane Kastorsky, da rede pública de ensino - Grupo UTA, a Companhia de Teatro Uta foi formada em abril de 2003, com a participação de alunos, professores e "amigos da escola", com o objetivo de participar do Festival Municipal de Talentos, no qual o grupo obteve o primeiro lugar.

No Festival Regional de Teatro, que se deu na cidade de Votorantim, o grupo alcançou a melhor premiação e no Festival Regional de Teatro da Secretaria da Educação do Estado de São Paulo, fase pólo em Sorocaba, e o grupo obteve o segundo lugar.

Essas premiações incentivaram a Companhia de Teatro Uta a levar a montagem cênica às cidades da região: Salto de Pirapora, Piedade, Votorantim, Cesário Lange e Sorocaba.

Em 2004, a Cia. de Teatro Uta optou por abordar tema relativo à Grécia, pois este seria muito explorado devido à realização das Olimpíadas, em 
Atenas. Foram adotadas como base as seguintes obras: Odisséia, de Homero; Medéia, de Eurípedes; Antígona e Édipo Rei, de Sófocles; Prometeu acorrentado, de Ésquilo. A montagem recebeu o nome de Lendas - $O$ Pentágono Grego. O grupo obteve o 3. no Festival Estudantil Sesi de Teatro, ficando com a seguinte premiação - 2.. Melhor Espetáculo Teatral - adulto; Melhor direção - Juliano Casimiro; Cenografia - Dorival de Souza; Ator Revelação: Jackson Emílio. Com a saída do diretor, Juliano Casimiro, a prof. a Jane Kastorsky, que até então era assistente de direção, tomou a frente dos trabalhos de direção do grupo.

Como os objetivos eram o de integrar a comunidade estudantil da cidade através de uma manifestação artística; participar de diversos festivais e ainda realizar um intercâmbio cultural entre as cidades da região, decidiu-se, depois de várias pesquisas, adaptar a peça $O$ Tartufo, de Molière, tradução de Jean Melville. Alguns trechos de outra peça de Molière, Don Juan, foram introduzidos na montagem, que retrata a aristocracia e a burguesia francesa do século XVII. O objetivo era o de conduzir a platéia a uma reflexão da realidade sobre a qual se constrói vidas, desejos, sonhos. A peça aborda as relações humanas envolvendo religião, fé, religiosidade, poder e ascensão social.

A Cia. de Teatro Uta fez três apresentações no Recinto de Exposições e Festas "Antonio Carlos Farrapo", pois não havia ainda um teatro na cidade. Participou do 4.․ Festival Estudantil Sesi de Teatro, onde obtive onze indicações e a seguinte premiação: Melhor lluminação Felipe Nóris / Vinícius Rostelato; Ator Revelação - Vinícius Rostelato; Atriz Revelação - Gérica Santos; Atriz Coadjuvante - Gisele Berenguel.

Em 2006, a Cia. de Teatro Uta, passou por grande renovação com a saída de quase todos os alunos do trabalho do ano anterior. Foram abertas inscrições para novos integrantes e muitos alunos passaram a participar das oficinas e foi escolhido o texto para crianças, de Ronaldo Ciambroni, Tucunaré - A filha da Lua. Com ensaios apenas uma vez por semana, aos sábados, fazendo parte do Projeto Escola da Família. O tema da 
peça era ecologia, mais precisamente sobre o tema Amazônia, Floresta Amazônica. Fizeram cinco apresentações em Salto de Pirapora e participaram do 5. ${ }^{\circ}$ Festival Estudantil Sesi de Teatro, na categoria teatro para crianças, onde obtiveram seis indicações: cenário, figurino, maquiagem, sonoplastia, atriz- Gisele Gomes, atriz coadjuvante - Daiane Fernandes, e ganharam os prêmios de melhor iluminação e 2.․ melhor espetáculo na categoria infantil.

O trabalho da Cia de Teatro Uta, vem sendo a cada dia motivo de orgulho para a escola e para toda a comunidade. Os alunos fizeram um bom trabalho de pesquisa sobre a Amazônia, tribos indígenas, em especial a tribo dos Tucunas (retratada no texto), sobre a situação atual da Floresta Amazônica e dos índios habitantes daquela região. Toda a escola se envolveu, pois o tema: preservação do meio ambiente, em especial o da Amazônia, faz parte do Projeto Político-Pedagógico.

No mês de outubro, realizaram um seminário intitulado Brasil: um país de todos, em que palestrantes abordaram, entre outros assuntos, a situação do índio e da Amazônia, e os alunos do grupo de teatro se apresentaram, com performances.

Nos meses de outubro e novembro fizeram em Votorantim (três apresentações) e, em São Paulo, participaram da /l Mostra de Teatro, realizada pelo Colégio Santa Marcelina.

Em dezembro, novamente apresentaram-se na cidade Salto de Pirapora, encerrando a Semana Cultural Afonso Vergueiro. Semana essa que contou com a presença de grupos teatrais da região - Grupo Cia Tereza - de Sorocaba, Grupo Tapanaraca - de Itapetininga e Grupo Tal\&Pá, que veio de São Paulo, com a peça Arena conta Zumbi, especialmente, para realizar esse intercâmbio cultural. Além dos grupos, houve oficinas de teatro com os alunos da Uniso - Viagem teatral, grupos de dança, bandas etc.

Foi um ano muito proveitoso em que a aprendizagem se deu através da Arte. A comunidade saltopiraporense vem a cada ano prestigiando mais e mais o trabalho do grupo. 
Em 2007, com nove novos integrantes, após oficinas e todo um processo de amadurecimento dos alunos, resolveram repaginar a peça do ano passado, cuidando principalmente de detalhes apontados pelos jurados do 5. Festival do SESI. O resultado do trabalho recebeu o nome de Uma lenda da Amazônia,o qual foi mostrado no 6. ․ Festival do Sesi.

A Trupe Catavento, grupo de teatro do Colégio Anglo Boituva, surgiu como proposta da escola, em comunhão com uma vontade dos alunos. Teve início com a prof ${ }^{\underline{a}}$ Laura Baggio e, desde 2007, é coordenado pelo profo ${ }^{-}$Thiago Leite, época em que se fixou como disciplina curricular na escola. O grupo, estimulado pela Mostra Estudantil de Teatro da Cidade de Boituva, foi se fixando cada vez mais no Colégio, e hoje é elemento fundamental das atividades culturais escolares.

O Grupo Teatral Tapanaraca surgiu com o intuito de formação de público. Para isso, os três atores - Diogo Cruz, Ailson Martins e Lucy Villar - e o diretor Fábio Jurera, começaram a montar espetáculos de no máximo vinte minutos para apresentar nos intervalos das escolas. A aceitação foi muito boa e depois de um ano com esse formato, a escola Abílio Fontes nos chamou para perguntar se não estaríamos interessados em montar um grupo com seus alunos dentro da instituição de ensino. Foi uma surpresa e o início de um novo rumo para o grupo. O elenco foi escolhido por meio de um teste promovido pela escola. Aproximadamente 710 alunos participaram do teste. Destes 70 , 18 foram selecionados para o elenco e mais 20 para ajudar na equipe técnica. A inclusão do teatro na escola Abílio Fontes foi extremamente positiva, mas depois de dois anos (o grupo então com três anos) a direção da escola mudou, e 0 teatro foi proibido. Mudamos então de sede escolar, partindo para o Instituto Peixoto Gomide que também já havia nos procurado. No Peixoto, o grupo se encontrava durante os finais de semana no Programa Escola da Família, mas com a participação dos alunos da própria escola. A cada seis meses havia uma apresentação no horário escolar para que os alunos da escola pudessem prestigiar o trabalho do grupo e de seus colegas. E aos poucos a parceria entre o grupo e a escola foi se fortificando cada vez mais.

O último grupo, a Cia. de Teatro Tal\&Pá da Escola Estadual Professora Maria Augusta de Ávila, foi criada em 1994, dentro do projeto 
Educação por processo de grupo através do Teatro, na Escola Estadual Professora Maria Augusta de Ávila, em Artur Alvim, Zona Leste de São Paulo, com o objetivo de oferecer à comunidade uma opção de cultura e lazer, uma alternativa às drogas e à violência da cidade. Ao longo dos anos, configurou-se como um grupo estável e criou um estilo que pode ser reconhecido em suas montagens. Em 2008, ampliou esse trabalho, desvinculando suas atividades do âmbito escolar e democratizando a participação de todos os interessados. O projeto inclui, em sua nova fase, a dança, a música, as artes plásticas e oficinas literárias.

O projeto de teatro foi construído a partir do programa Decide de combate ao uso de drogas, resultado de muitos anos de estudo e pesquisa realizados por especialistas de diversas áreas de ensino, levando em conta as peculiaridades intelectuais e emocionais de cada faixa etária.

O grupo surgiu a partir de um evento escolar anual chamado $A$ Casa do Terror, que angariava fundos durante as festas juninas. Nesse evento, um grande auditório era transformado em percurso aterrorizante, no qual os alunos se revezavam em performances inspiradas nos grandes clássicos do horror. A cada ano, os cenários ganhavam maior produção, as performances tornavam-se mais elaboradas e a expectativa do público escolar crescia. Crescia também o número dos "artistas" que pretendiam participar do evento: cerca de sessenta jovens dividiam o espaço todos os anos para divertir 0 público e mostrar seu talento.

Desfazer o grupo ao final do evento criava um inevitável sentimento de frustração. Era evidente a necessidade de um tempo maior para que estes jovens pudessem se expressar. De sua própria iniciativa, um texto rudimentar, inspirado num musical feito para o cinema nos anos oitenta, daria origem ao primeiro espetáculo do grupo. 
A companhia encontrou seu caminho, orientada pela intuição e pela busca de uma estética pessoal que refletisse sua visão de mundo, inserida em seu contexto social, na busca de alternativas transformadoras da realidade. Acumulou diversos prêmios ao longo da carreira, participando dos principais festivais de teatro estudantil de São Paulo.

Quase trezentos integrantes fizeram parte do Tal\&Pá, em seus quatorze anos, de atividade. As dificuldades não assustam essa trupe que promete não desistir do seu ideal. Afinal, eles vivenciam em seu trabalho a extraordinária capacidade da arte - nesse caso, o teatro - de transmitir mensagens simbólicas, de influenciar a vida emocional das pessoas e, ao mesmo tempo, despertar sua consciência política, em busca de condutas mais socializadas, eticamente mais humanas, gerando um espaço de convivência mais tolerante e mais democrático.

Várias perguntas foram elaboradas para que as professoras pudessem definir e esclarecer melhor os seus trabalhos.

Uma dela foi sobre qual a transformação de um aluno que participa de um grupo de teatro estudantil. Em resposta, a professora Pámela Paz disseme que o aluno que ingressa em seu grupo fica, num primeiro momento, deslumbrado com a possibilidade de criação, não sabe ainda canalizar suas energias para trabalhos coletivos, só aos poucos é que vai conseguindo concentração e disciplina nos exercícios teatrais. O crescimento do aluno e do grupo é de forma paulatina e, à medida que o aluno cresce, o grupo se torna ativo e, conseqüentemente, o aluno mais participante nas aulas teóricas, com desenvoltura nas atividades culturais, nas palestras, nas organizações de festas dentro do colégio e nos debates.

Já a professora Jane Kastorsky acha que o aluno se torna mais responsável, uma vez que se apropria de um determinado conhecimento de forma diferenciada, ressignificando-o.

O coordenado do grupo Trupe Catavento, profo Thiago Leite diz que dentro do ambiente escolar, o que se nota é que os alunos que participam do grupo de teatro, diferenciam-se por questões de comunicação e desprendimento nas relações interpessoais estabelecidas dentro do coletivo. 
As observações feitas dentro da Trupe Catavento, grupo que é formado por alunos do Colégio Anglo de Boituva, deixam claro que as características dos alunos participantes do grupo, talvez a mais forte, seja a disponibilidade, aspecto esse não só com relação a horários para os encontros, mas também às propostas dentro destes. Disponibilidade para o Jogo, para a cena, e para a relação com o outro. Além de uma responsabilidade adquirida, durante essa relação, responsabilidade com o grupo, para com o outro e para com si próprio, uma vez que a presença do aluno é exigida a todo instante. Aumento da percepção, e da sensibilidade para com fazeres do cotidiano, para com seu próprio corpo e o universo que o rodeia, casa, escola e amigos.

O prof $^{0}$ Fábio Jurera, do Grupo Tapanaraca, diz que normalmente quando os alunos da escola são informados a respeito do grupo de teatro e de que podem participar, alguns comentam em tom de brincadeira que vão entrar somente para poder sair durante as aulas chatas, já que algumas vezes acontece de ter apresentação ou ensaio durante o horário de aula. Depois de um tempo no grupo, aqueles que continuam se mostram muito mais interessados inclusive durante as aulas, pois só se mantém no grupo alunos com notas acima da média.

Esse acordo feito entre diretor teatral e diretor escolar, sempre trouxe bons resultados, pois já houve casos em que o "pior aluno" da classe pediu para entrar no grupo de teatro, depois de estar ativo no grupo, ele sabia que era preciso se manter com notas boas também no boletim. Os depoimentos de professores são de que esse aluno mudou completamente de atitude durante as aulas, prestando mais atenção, participando ativamente das aulas e suas notas que quase sempre eram negativas, passaram a ser uma entre as maiores da sala em todas as matérias curriculares.

Segundo a professora Valéria de Oliveira, os estudantes aprendem e ganham experiência em formas de expressão, liderança e organização, pensamento crítico e responsabilidade pessoal, que refletem num melhor desempenho em sala de aula e no seu cotidiano. O estudante fica mais ciente dos outros e, assim, é capaz de se avaliar em função do todo.

Por meio do teatro, eles descobrem novas formas de comunicar e interagir, tornam-se mais conscientes da linguagem do corpo e da expressão, 
do movimento, da música, das imagens e do espaço, e aprimoram suas possibilidades de comunicação verbal. Desenvolvem senso estético e artístico e passam a valorizar e desfrutar mais da pluralidade de manifestações culturais.

Durante o processo, o aluno fortalece sua autoconfiança e estabelece uma auto-imagem positiva, necessária para atuar de modo crítico e seguro no seu cotidiano, bem como aprende a buscar soluções coletivas, exigências básicas das práticas sociais e do mercado de trabalho atual.

Fica claro que quem participa do trabalho passa por um rito de passagem, nunca mais será o mesmo. Torna-se uma pessoa mais informada, mais atenta, mais solidária; enfrentou um desafio e o venceu. Cresceu.

A partir da resposta da professora Pámela podemos primariamente concluir que a formação dos grupos de teatro dentro de um colégio da rede particular é uma espécie de ameaça à disciplina na escola, a direção, às vezes, os vêem como perturbadores da rotina da escola, infringindo as regras de condutas.

Ao pedir às professoras para comentar como a escola entende 0 trabalho desenvolvido pelos grupos de teatro. A professora Pámela Paz respondeu-me que, no início, ela tinha apoio financeiro para a produção do espetáculo, mas a escola passa por mudança do quadro diretivo a cada quatro anos e a cada mudança o apoio financeiro foi ficando cada vez mais escasso, pois os diretores que entram não os conhecem e sempre ficam na expectativa do seu trabalho.

A professora Jane Kastorsky disse que a escola entende e valoriza o trabalho do grupo, mas reconhece que o aluno integrante do grupo fica visado, uma vez que não só suas atitudes, comum a qualquer adolescente, são mais reparadas, cita alguns comentários que ouve: "olha lá, é aluno do teatro... eles deveriam dar o exemplo", como também o comportamento dentro de sala de aula e suas notas são sempre cobrados. Além de encontrar grande dificuldade com relação ao local dos ensaios, pois não tem lugar específico para aulas de teatro, ensaia na quadra da escola o que é muito desgastante porque sempre depende do tempo - sol e chuva, frio o calor- e barulho. 
O prof. Thiago Leite, da Trupe Catavento diz que dentro do Colégio Anglo de Boituva, existem aulas de Teatro curriculares. A estrutura curricular do colégio propõe-se a utilizar o teatro como meio de desenvolvimento do aluno, quanto à comunicação e à ampliação de sua sensibilidade diante de seu ambiente. Assim, os alunos, desde o $1^{\circ}$ ano do ensino fundamental, tem aulas de teatro, disciplina que se estende até o $7^{\circ}$ ano, para os alunos de $8^{\circ}$ e $9^{\circ}$ anos, as aulas são extracurriculares e ocorrem como grupo. Os alunos que fazem a disciplina durante o período letivo também participam desse grupo, nos quais são montados espetáculos. Dentro dessa realidade, de implantação do Teatro como matéria em sua grade, e todo suporte dado a esse curso dentro do colégio, fica claro a percepção da escola no que se refere às aulas de teatro e ao grupo existente, o qual é propósito do próprio colégio, como atividade de complementação cultural e artística da formação dos alunos.

Segundo o prof. Fábio Jurera, do Grupo Tapanaraca, no início sempre há um receio da coordenação da escola, pois não sabem ao certo como o grupo vai ajudar ou até mesmo "atrapalhar" na rotina escolar. Porém sempre há um professor que apóia e dá dicas no início do processo de lugar de ensaio e horário que não vá dar motivos para reclamarem. Depois da primeira apresentação, a aceitação é automática, resultado da satisfatória evolução das crianças tanto no teatro quanto no próprio convívio escolar. Problemas sempre existirão, e a aceitação nunca atinge $100 \%$ da equipe escolar, mas é só por meio de desafios que o grupo de teatro se mantém.

E a professora Valéria de Oliveira diz que com relação à instituição em que trabalha nunca houve qualquer forma de restrição. A primeira necessidade do corpo administrativo é criar regras e regimentos que "enquadrem" a atividade nos moldes propostos pela educação oficial, quase todos falidos de longa data. Depois criam artifícios para contornar as dificuldades criadas pela própria estrutura. A maior dificuldade é fazer com que o projeto seja integrado à proposta pedagógica e deixe de ser visto como atividade paralela, ou que, pelo menos, seja entendido como projeto pedagógico e não como cartão de visitas de luxo. O apoio necessário não se resume aos recursos financeiros necessários (que nunca vêm...), ao espaço físico ou ao cronograma especialidades da casa. Sem um trabalho de formação de público, professores 
e alunos tornam-se objetos de manipulação e marketing dentro da política educacional. $O$ que encontramos são pessoas bem intencionadas que oferecem sua "solidariedade" ao projeto, valorizando o "esforço" dos participantes e o "resultado" do trabalho.

Aprender a trabalhar juntos - professores, alunos, direção, coordenação pedagógica - consiste na principal dificuldade a ser rompida, bem como a barreira das vaidades pessoais. Fazer obedecer às nossas ações a um propósito definido coletivamente e pensar em estratégias que levem a sua concretização, seria, de fato, aprender a fazer uma educação mais interessante.

Diante do exposto, pode-se dizer que o aluno que participa de um grupo de teatro dentro da escola da rede particular, muitas vezes é mal visto por alguns professores, que vêem naquele aluno total falta de comprometimento com os estudos, pois para muitos desses professores o aluno ideal é aquele que fica sentado atrás de uma carteira apenas na escuta de explicação do referido mestre.

O aluno enfrenta além da discriminação, por parte da escola, também certa rejeição da família, que entende que o teatro deseduca, leva o aluno a práticas de comportamento não aceitável pela sociedade, além de dispersá-lo do foco das principais matérias.

Segundo Baudrillard (1981), na atual sociedade do consumo de massa os homens vivem às voltas com simulacros, isto é, com o fazer de conta, como o fingir, com as aparências. E, dentro dessa perspectiva, são os meios de comunicação que constroem os simulacros da realidade através de imagens que intencionam não só representar o mundo, mas substituí-lo. O que se vê é que o simulacro é colocado no lugar da própria coisa, apoiando, sua aparente vantagem, no fato de possuir mais atrativos do que ela. $O$ aluno, no cotidiano escolar, vive sob o regime do poder disciplinar.

Procuro enfocar essas dificuldades de discriminação, vivenciadas pelo aluno que participa de um grupo de teatro na escola e na família, por entender que esses processos dos festivais contribuem de uma maneira significante na 
mudança de comportamento dentro das escolas e não com tanta propriedade junto das famílias.

Segundo a expectativa da família de um aluno originário de classe média ou média baixa, o ideal é que ele se profissionalize, que se torne um metalúrgico, um operário especializado ou qualquer profissão técnica. 0 importante é que tenha uma carteira assinada. Aquele que vem de uma classe média ou média alta é que se torne um colecionador de títulos, um profissional liberal ou um grande empresário.

E essa luta do aluno é que torna esse trabalho nas escolas mais gratificante, não que esses grupos tenham a pretensão de formar artistas, mas um cidadão mais politizado e consciente da sua própria existência, e que entenda que ele deva escrever sua própria história e não a repetição da história de seus pais.

Aos grupos de teatro são destinados, muitas vezes, os porões da escola, quadras poli-esportivas ou os galpões de recreação para serem realizados os estudos e ensaios. Os grupos têm que dividir ainda esses espaços com os projetos de importância para o governo e para seus dirigentes, como projeto escola da família, amigos da escola e gincanas esportivas. Mas o trabalho desses grupos tem força e, por sua própria natureza, consegue se expandir e chegar a resultados que superam esses limites.

Dentro da própria escola consegue-se formar toda a parte técnica de maneira artesanal. Os próprios alunos se encarregam de procurar entre eles pessoas que saibam lidar com som, que vai funcionar como sonoplasta, aquele que trabalha com madeira ou construção para executar a cenografia e dentro desse processo se estabelece um trabalho de total inteiração e riqueza em pesquisa, muitos não direcionados antes de chegar a um festival,

Ainda que todo esse processo de construção seja absolutamente artesanal e amador é de fundamental importância que o mesmo seja visto e analisado por pessoas que entendam e dominem a linguagem teatral, até mesmo para que possam estabelecer a dimensão e o valor do trabalho dos alunos e professores. 
As dificuldades são muitas para não dizer que são todas, não existe verba nenhuma, tudo tem que ser conquistado e conseguido. As escolas não dispõem de verba para execução de trabalho desta natureza, a Associação de Pais e Mestres - APM - órgão que tem como objetivo arrecadar verbas junto aos alunos e para isso criam festas, com o intuito de destinar tudo o que se arrecada para manutenção do prédio escolar. E os grupos de teatro ainda têm que enfrentar essa disputa dentro da própria escola, ou seja, suas arrecadações não podem contar com festas e contribuição junto à escola, tudo tem que ser destinado à $A P M$.

O material para figurino, cenografia e outros têm que ser adquiridos junto à comunidade e sempre vai depender do esforço coletivo dos alunos envolvidos e de suas famílias.

Os ensaios ficam sempre para horários alternativos da escola, ocorrendo nos finais de semana de maneira a não atrapalharem o andamento dos projetos já mencionados. E tem ainda que contar sempre com o apoio de um professor que se dedique a essas horas trabalhadas, muitas vezes, sem remuneração alguma.

Mas todas essas dificuldades não impedem os trabalhos de serem realizados. As professoras acreditam na importância do teatro-educação e da arte como suporte possibilitador do desenvolvimento de um espírito crítico. Visivelmente, os alunos que participam de movimentos de teatro dentro da escola começam a ter uma fidelidade maior aos horários dos compromissos e isso torna o trabalho do teatro relevante dentro do contexto escolar, pois o aluno do teatro acaba inserido em todas as manifestações da escola, desde desfiles cívicos até montagens de festas de formatura, muitas vezes, também, tomando conta dos grêmios estudantis.

Ao responder sobre a relação dos grupos com os festivais de teatro estudantil, as professoras tiveram a mesma opinião. Acham que 0 melhor ao participarem desses eventos é o de criar vínculos com os outros grupos, a possibilidade de fazer pesquisas para montagem de espetáculos, as discussões que giram em torno do tema, interpretação, figurino, iluminação, música etc. Todos os desafios que os alunos tentam ultrapassar e, ainda, o 
que consideram mais importante, a vontade de participar de outros festivais estudantis.

Com relação a como se sentem os grupos na participação do Festival Estudantil Sesi de Teatro em Sorocaba, a professora Pámela Paz, do Grupo Teen de Teatro Santo Agostinho, considera-o como uma das melhores propostas de festivais em que participou, principalmente por que tem como objetivo a valorização dos trabalhos dos grupos, porque julga a evolução dos trabalhos dos grupos no seu total e não a perfeição das partes. Como dirigente de grupo estudantil, sabe o quanto é difícil trabalhar. Geralmente, o grupo é composto por um número excessivo de componentes, portanto, torna-se quase impossível conseguir uma uniformidade. Essa valorização no todo é extremamente positiva, pois 0 aluno se sente mais valorizado e, conseqüentemente, mais estimulado em seu crescimento pessoal e em sua formação.

Ao ser premiado pelo todo, o troféu traduz a participação, 0 desempenho e o êxito do grupo, mesmo quando o prêmio é dado individualmente para as categorias de melhor atriz, figurino, cenografia, iluminação etc., pois os alunos percebem que ninguém cresce sozinho, só o trabalho em grupo que vai destacar cada um. O sucesso de cada um depende do trabalho de todos.

Ressaltou que as oficinas oferecidas durante o festival, realizadas por profissionais de altíssima competência, são importantíssimas para ajudar na performance dos alunos - uma vez que quebra com a expectativa e ansiedadeno entrosamento dos alunos com os participantes dos outros grupos.

Observa também que esse festival faz sempre muito bem aos alunos que participam. Ele consegue fazer o grupo ser valorizado dentro da escola e na comunidade.

Para Jane Kastorsky- Grupo UTA, participar do festival do Sesi é muito importante, pois ela percebe que se valoriza muito o trabalho feito pelos professores na escola. 
A organização do festival é impecável e os jurados têm a preocupação de julgar todo o processo e não o produto final. Isso não significa que os julgadores não cobrem qualidade nos espetáculos.

Vê com bons olhos a participação nos festivais, ao retorno dos alunos, como o sucesso do festival está refletido na vida do aluno que pertence ao grupo, nos alunos da escola, na direção, nos professores e nos funcionários. O aluno integrante do grupo de teatro sente-se como parte de algo muito importante para sua vida, sem contar que eles aprendem muito com essa experiência.

O festival acaba movimentando toda a escola. Os alunos que não participam do grupo de teatro torcem, incentivam, assistem aos espetáculos na cidade, compram ingressos para ajudar no figurino, vão à apresentação no Sesi. Direção, Diretoria de Ensino de Votorantim, professores e funcionários da escola atuam nos bastidores, ajudando em tudo o que thes é possível: liberando professores, funcionários envolvidos com o grupo; ajudam na captação de verbas para a realização do projeto. A Diretoria de Ensino não só libera a professora para participar das oficinas oferecidas pelo Sesi Sorocaba, como também oferece aos outros professores, de sua rede, um intercâmbio com outros professores de Artes.

Os professores e os funcionários da escola também ajudam na confecção do figurino da peça, na preparação de lanches para o grupo, na limpeza do local para as apresentações, na montagem da "caixa preta" em um salão de festas da cidade.

Fala de como é gratificante ver, que a cada ano que passa, mais pessoas acabam se envolvendo com o trabalho do grupo. É perceptível o aumento do número de pessoas indo assistir o espetáculo. Em 2006, chegaram a levar 2.500 pessoas ao festival.

Concluindo, numa cidade pequena, como a de Salto de Pirapora, o trabalho do grupo vem sendo, a cada dia, mais valorizado e respeitado pela comunidade. E o festival do Sesi de Sorocaba é parte importantíssima desse processo, no que diz respeito a cada participação, a cada conquista de prêmios, a cada oficina. Enfim, em tudo que colaborou e colabora para uma 
transformação social, na mudança da comunidade, pela possibilidade de criar uma nova visão de mundo, mais crítica, por meio da arte teatral.

Ao falar de sua participação do festival a Trupe Catavanto explica que, dentro da própria cidade de Boituva, existe uma Mostra Estudantil de Teatro, onde os grupos das escolas do município preparam peças para participação. Esse foi um dos projetos que impulsionaram o grupo dentro da escola, uma vez que depois da participação, mais alunos começaram a se interessar pelo grupo. Depois, em 2007, quando o grupo participou do Festival Estudantil realizado pelo SESI de Sorocaba, outra dimensão foi tomada dentro da escola, o festival veio por solidificar mais ainda o trabalho, sua importância dentro da escola e esclarecer de qual maneira esse grupo, segue um processo de trabalho relativamente interessante como proposta pedagógica.

Dentro do festival, a troca de experiências com outros grupos e com o próprio júri, nos debates, enriqueceu e clareou muitas questões que tínhamos em pendência. Principalmente com relação aos alunos. Mesmo estando cientes do trabalho desenvolvido, muitos dos alunos só percebem a riqueza e seu próprio desenvolvimento durante o festival, pois tem a opinião do outro, o olhar do outro para seu trabalho, existe a necessidade de uma auto-afirmação, seja por aspectos positivos ou negativos. Assim, um aprendizado ocorre quando através do outro o aluno percebe questões internas que antes não tinha notado. Além da possibilidade de vivenciar a experiência de um edifício teatral em que a junção de vários elementos como iluminação, coxias, palco, platéia, elementos esses que, muitas vezes, não existem na realidade do aluno. Portanto, a relação com o espaço, com as pessoas, as proposições apontadas pelo júri, e principalmente a formação que se adquire ao longo dos festivais, pelo orientador do grupo e pelos próprios alunos, interfere absurdamente na solidificação dos grupos.

O Prof. Fábio Jurera lembra que foi num dia de apresentação que chegou as suas mãos, por meio da diretora da escola, a ficha de inscrição do 4ํ Festival Estudantil Sesi de Teatro. Haviam acabado de estrear o espetáculo O Circo llusão (texto de Fábio Jurera). Foi algo até então inesperado pelos integrantes e até mesmo pela direção do grupo. Foi combinado com a escola de fazer uma apresentação aberta para os pais no final de semana, e neste dia 
seria gravada a fita para enviar ao festival. Com a notícia da aceitação do espetáculo, o grupo passou por mudanças. O figurino não podia ser o que havia improvisado para as apresentações, ainda era preciso acertar alguns detalhes a respeito de voz, articulação. A única coisa que não conseguiram resolver era uma carteira escolar que utilizavam em uma das cenas e foi uma das coisas apontadas pelos críticos do festival.

Depois de passar por essa experiência e poder mostrar para os pais e para a escola, a importância do teatro na vida daquelas crianças, recebeu-se apoio significativo de todos os lados e a cobrança sempre positiva de algo melhor para o ano seguinte.

E a professora Valéria de Oliveira disse que embora a maioria dos festivais leve em conta somente o resultado final e não o processo como um todo, os festivais estudantis de teatro dos quais participou têm como um de seus méritos não negligenciarem a parte mais importante do trabalho educacional, através dos debates e cursos promovidos.

Em 1999, o grupo recebeu com muita surpresa a notícia da classificação para o Festival Estudantil de Teatro do Estado de São Paulo, um certame cultural promovido pela Secretaria de Estado da Cultura, através do Conservatório Dramático e Musical "Dr. Carlos de Campos" de Tatuí. A Escola Estadual Maria Augusta de Ávila passava a fazer parte do seleto grupo de doze participantes escolhidos em todo o estado que vivenciariam ali uma experiência única de teatro.

O festival era respeitado como um dos mais bem sucedidos no país, dentro de sua proposta estudantil. Durante oito dias, dois integrantes de cada escola participariam de oficinas com importantes nomes do meio teatral, assistiriam a todas as peças do certame e tomariam parte nos debates realizados ao final de cada apresentação. A possibilidade de trocar experiências com profissionais das mais variadas vertentes foi enriquecedora.

Diante daquela nova realidade, a despeito de sua importância enquanto trabalho de formação de grupo, ficava evidente a fragilidade do processo de criação teatral desenvolvido pelo Grupo Tal\&Pá. O júri, formado por profissionais na área de Teatro (não necessariamente vinculados à Educação), 
foi muito severo. Mas valeu a segurança do grupo e a consciência de seus objetivos para não se deixar abater. Apesar de satisfeito com a proposta educacional desenvolvida até ali, o Tal\&Pá se defrontara com possibilidades desconhecidas até então. Era inevitável repensar os rumos daquele projeto, e essa evolução só foi possível graças à experiência de Tatuí.

Nos últimos anos, continuaram a participar dos festivais estudantis, pela oportunidade preciosa de discutir os trabalhos com outros profissionais do Teatro e Educação. As dificuldades sempre muitas, especialmente com relação aos custos de transporte e estrutura. Prêmios em dinheiro financiam o trabalho do ano seguinte, mas não são essenciais. Já a ajuda de custo aos participantes selecionados pode ser um fator determinante para que um grupo, saindo do anonimato em uma escola distante, possa fazer parte desse círculo tão enriquecedor.

Defende ainda que os festivais só são válidos quando não se transformam no objetivo fundamental do trabalho. É necessário que se coloque a ênfase do processo de aprendizagem no aluno e sobre o processo em si, e não sobre o resultado ou o produto final a ser obtido. Contudo, a conclusão de que uma montagem teatral e a participação num grande evento desperta a noção de que é possível atingir metas, com dedicação pessoal e trabalho de equipe. Situa a escola como espaço cultural representante da comunidade, aproxima jovens e familiares, envolvidos numa causa comum. Reduz as diferenças sociais na medida em que torna todos iguais no palco.

Como verificamos nos depoimentos dos professores no final das entrevistas, em que as mesmas relatam sua satisfação em perceber 0 crescimento do grupo, visto que os alunos que estavam meio perdidos no começo, aos poucos, foram crescendo e se estabilizando; adquirindo domínio corporal, controle e autoconfiança e isto representa a seu ver o maior mérito do trabalho. Apesar de todas as dificuldades é possível fazer um trabalho de qualidade, em que se dê oportunidade aos alunos de se auto-conhecerem, conhecer o universo teatral, assistirem a bons espetáculos e desenvolverem uma consciência crítica cidadã. Enfim, construir conhecimento de forma diferenciada, com responsabilidade e disciplina. 
Tal trabalho desenvolvido pelos professores promove a inclusão do indivíduo em todos os momentos das aulas. Para Thiago Leite, da Trupe Catavento, "durante os jogos e exercícios propostos, essa inclusão acaba por acontecer naturalmente. Com relação à entrada dos alunos no grupo, semestralmente são abertas as inscrições para participação do processo, deixando, assim, vago a possibilidade de todos os alunos participarem. Algo interessante que acontece, é a porcentagem de alunos sempre presente nas aulas. Constantemente, nota-se que cerca de $25 \%$ a $30 \%$ dos alunos da escola participam do grupo de teatro, esse número chega a ser maior, no início das aulas mas, no decorrer do processo, alguns alunos acabam desistindo, ou por não se identificarem com o trabalho, ou por estarem em dificuldades nas matérias escolares.

Como as aulas de teatro existem desde as primeiras séries do ensino fundamental, quando o aluno chega ao $6^{\circ}$ ano, já está apropriado da linguagem, de como se dá o processo através dos jogos teatrais. E mesmo tendo as aulas curriculares, mas sem acontecer, necessariamente, montagem de espetáculos, vai ao grupo para complementar as experiências vivenciadas em aula. $O$ aluno não perde o princípio da construção de um exercício cênico em que terá de dialogar com companheiros, de outras idades, com experiências distintas.

Dando continuidade ao Festival Estudantil, o Sesi junto com a TV TEM,

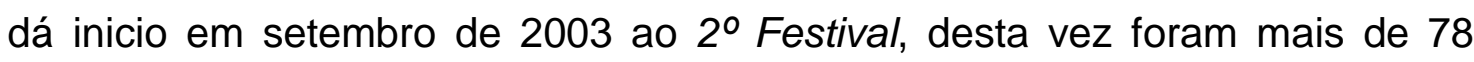
peças inscritas, apenas 10 foram selecionadas para esta segunda edição do Festival Estudantil. Na condição de Coordenador de Teatro do Sesi, lamentavelmente, concluí que poderíamos ter selecionado mais espetáculos, mas, na verdade, não teríamos como abrigar a todos. Como aumentou consideravelmente o número de inscritos, esperava que para as próximas edições fosse possível selecionar mais grupos.

A escolha das montagens participantes foi feita, baseada na proposta apresentada por cada uma delas. Foram escolhidas as que tinham um perfil escolar, desenvolvido dentro da escola. Lembro-me que, ao contrário de antigamente, quando o teatro era visto como algo subversivo, que não podia 
ser praticado nas escolas, hoje em dia ele faz parte do cotidiano dos estudantes.

Noventa por cento dos espetáculos são realizados por quem já tem alguma experiência na área: ou um professor que nas horas vagas é ator, ou um aluno, e aí fica mais fácil de transmitir aos demais. Apenas dez por cento dos espetáculos são dirigidos por professores de português, que também estão de certa maneira nessa área. Nesta segunda edição do festival, o público que foi conferir as apresentações pôde encontrar novidade à noite, logo na entrada do TPS, pois houve um painel vivo com alunos do Núcleo de Artes Cênicas (NAC) do Sesi.

O Festival Estudantil Sesi de Teatro tem suas peculiaridades, não é nada inédito, mas tem muito claro seus objetivos, e procuramos sempre estar refletindo sobre o objetivo inicial.

Uma delas é quanto à premiação que vem sendo alvo de grandes discussões. Qual é a real importância dos prêmios?

Poderia ter valor de uma moeda de troca a fim de obter apoio da direção das escolas. Muito se tem pensado sobre isso, até porque se observa que a escola não premiada pode ser fadada a finalizar o trabalho, pois sua direção vê o festival como um campeonato, quase esportivo e, muitas vezes, os dirigentes não têm a dimensão do trabalho realizado com o teatro. Vale ressaltar que a premiação incentiva sim os grupos, pois em decorrência dessa premiação que se consegue algum apoio, principalmente o aluno junto aos próprios familiares, que em sua maior parte não se interessam pelo espetáculo, mas vêem o prêmio como um resultado satisfatório que valeu a pena.

Não sabemos se realmente a premiação é benéfica ou não, mas ainda faz parte do contexto, principalmente escolar, onde tudo é avaliado por notas. Como estabelecer um conceito para o alunado e direção de outra maneira? Ainda não se chegou a um conceito de avaliação que efetivamente gerasse uma medida real do valor do trabalho e empenho do aluno.

Outra questão: e a função do festival quando o espetáculo é julgado. Muitos equívocos também são cometidos pelos especialistas que desprezam o 
processo de trabalho, enquanto fator importante pedagogicamente, visualizando apenas o resultado final. Temos que ter como clareza que a função de um festival estudantil é indicar caminhos e incentivar a vivência nas artes cênicas.

E ressalto mais uma vez que existe a escassez de material sobre festival estudantil de teatro.

Uma tendência do festival estudantil é que ele fique apenas com os espetáculos oriundos de escolas de ensino médio e fundamental. Isso é uma discussão que vem sendo muito abrangente, pois não cabem, dentro deste festival, espetáculos universitários e amadores.

É um pouco redundante falar novamente sobre isso, mas não podemos deixar a essência desse festival se perder, que é a característica essencial de ser estudantil, em que se valoriza o processo de criação e não o resultado final.

Quero ressaltar, aqui, que o festival estudantil de Tatuí, quando começou e era feito apenas por estudantes de escolas, tinha um trabalho em que o criador Moises Miastikovis visitava as escolas, principalmente da cidade, incentivando as montagens, indicando textos e o festival era somente estudantil e, hoje, tem uma nova característica, que envolve espetáculos universitários entre outros.

Na observância do Festival Estudantil de Teatro Sesi de Sorocaba, alguns autores surgiram com muita freqüência desde a primeira edição, como Maria Clara Machado, Tatiana Berlinky, Ronaldo Ciambroni, na categoria teatro para criança. Curiosamente nenhuma obra de Oscar Von Phull apareceu, estes autores acima citados são os mais conhecidos e mencionados nos trabalhos realizados nas escolas. Na categoria adulto, a freqüência de autores não é muito significativa, observa-se muita colagem de textos e adaptações de obras literárias e criações de teatro coletivo que, muitas vezes, são chamados de colaborativos equivocadamente

Em relação à freqüência participativa nos festivais, temos casos significativos como o de Thiago de Castro Leite que, na primeira edição, aparece como ator e cenógrafo, enquanto estudante da escola Chico Pereira; 
na segunda edição, aparece novamente como ator e cenógrafo; na terceira edição, já assume a assistência de direção, deixa a escola e entra na Escola de Comunicação e Artes, na Universidade de São Paulo e na quarta edição, aparece como iluminador do grupo, do Colégio Anglo, de Tatuí onde já trabalha como professor artista; na quinta edição, aparece como diretor do grupo do Colégio Anglo de Tatuí e assim, sucessivamente, até a sétima edição, vem participando como professor artista.

Thiago é, sem dúvida, resultado do festival estudantil, no qual visivelmente se percebe a importância função de um festival, gerando frutos. Hoje, Thiago é uma referência no trabalho que desenvolve com crianças. Ele trabalha como ator em montagens profissionais, mas seu trabalho de professor artista continua a ser merecedor de destaque.

Outro nome que podemos citar e da professora de português Jane Kastorsky que, na terceira edição, aparece como assistente de direção e, a partir da quarta edição, assume a direção e ingressa no curso de Pedagogia, no teatro da Uniso - Universidade de Sorocaba, o que leva seu trabalho a ganhar uma outra dimensão.

Outro nome que deve ser mencionado é o de Chico Neto que participa das três primeiras edições do festival e segue para o curso de Artes Cênicas da USC - Universidade do Sagrado Coração de Bauru. Chico vem de um trabalho junto ao seu grupo escolar onde começou como ator e cenógrafo no primeiro festival; no segundo, diretor e ator e no terceiro, como autor/ diretor e ator.

Recentemente, Benemari Sulivam, que apareceu no quinto festival como um convidado, participando apenas das oficinas e debates; participa da sexta edição, com um espetáculo para criança da escola onde desenvolve trabalho de professor artista; e na sétima edição, traz dois espetáculos, um para criança e um para adulto. Gostaria de ressaltar que a cidade de Quadra de onde esse grupo provém, tem apenas uma escola estadual e outra municipal e que a maior parte dos alunos é da zona rural, e o contato que esses estudantes têm com o teatro se dá apenas pelo festival estudantil.

Cito esses quatro casos, em especial, por entender que são fruto do 
festival estudantil de teatro, onde começaram a buscar e desenvolver seus trabalhos.

Coloco outros nomes que têm grande importância nos festivais no gráfico abaixo, mas saliento que os demais já têm histórico dentro das artes antes do festival Sesi Sorocaba de teatro.

Depois de todo esse detalhamento histórico e valorativo dos festivais cabe ainda um questionamento sobre qual o sentido de poder emprestar 0 nosso tempo para a construção e realização de um festival estudantil de teatro.

Podemos adotar vários conceitos e múltiplas ações, já foi levantada a questão de que o teatro desenvolvido nas escolas vai muito além dos espetáculos que chegam aos palcos, portanto precisamos analisar com mais detalhamento, as metodologias que vêm sendo utilizadas para fundamentar o trabalho do professor artista, dos autodidatas e dos "aventureiros". Abro um espaço para falar sobre "aventureiros". Uso esta nomenclatura não para falar sobre o aluno que desenvolve o seu trabalho, mas para aqueles que se aventuram de maneira duvidosa a dirigir, encenar e, enfim, representar o papel de líder só pelo fato de conseguir uma aproximação com um grupo de estudantes, que nem mesmo ele sabe qual objetivo ou que foco pode ser dado àqueles jovens.

Refletindo sobre o primeiro festival estudantil de teatro, observei que existem casos de "aventureiros" infiltrados nas escolas e, diante disto, sem medo de errar, sou favorável a que devamos apontar para superiores ou para quem quer que seja o responsável da escola ou centro comunitário que apure sua observação e que se faça um questionamento dos métodos ali desenvolvidos.

Em hipótese alguma estou levantando a censura à arte, mas ressalto a preocupação constante com esses jovens que, muitas vezes, saem de suas casas e vão para um ambiente até então tido como saudável, estimulados pelos seus pais e acabam sendo induzidos a práticas duvidosas do fazer teatral. Isto é um alerta recorrente que o professor artista que se fundamenta e que tem efetivamente uma proposta séria, pedagogicamente falando, deve estar sempre atento quando percebe o surgimento de um grupo de teatro. 
Quero abrir um recorte para esclarecer que, quando falo de aventureiro, não falo daquele aluno que estabelece contato com a leitura e dentro do seu convívio escolar resolve montar um espetáculo. Esse jovem exige uma atenção especial do professor artista, pois o surgimento desse tipo de trabalho que, muitas vezes, acontece em sala de aula ou fora dela, mas que é fruto da inquietude criativa de alunos que já têm um perfil artístico, resulte num produto, finalização de um processo, que pode ser considerado bom, do ponto de vista do fazer teatral. Esse aluno jamais poderá ser considerado como um aventureiro e é recomendável que possa ter espaço na escola, na condição de que 0 professor artista passe a orientá-lo para que ele mesmo possa desenvolver o seu trabalho, impedindo que o automatismo fique impregnado no fazer desse jovem.

A liberdade que esse jovem pode obter junto de seus amigos e companheiros vai colaborar para a construção de um processo de aprendizado que sempre será permeado por brincadeiras e jogos e vão poder desfrutar de um teatro estudantil, apenas com a orientação de um professor artista.

Tal proposta, sem dúvida, poderá ter grande participação da comunidade externa à escola e ainda agregar pais profissionais que thes darão alicerces na parte técnica; principalmente, se isto for desenvolvido em uma escola pública e de periferia, pois o aluno que vem de uma classe social mais desfavorável muitas vezes tem pais que poderão dispor de tempo e entende de carpintaria artesanal que dão suporte à encenação teatral.

Assinalo ainda que isso não é impossível de ocorrer em escolas de grandes centros e em colégios particulares, mas na observância dos grupos que participam do festival é o que fica evidente. 


\section{FREQUENCIA DE PARTICIPAÇÃO}

\begin{tabular}{|c|c|c|c|c|c|c|c|}
\hline & 10 & $2^{\circ}$ & 3응 & $4^{\circ}$ & $5^{0}$ & $6^{\circ}$ & $7^{\circ}$ \\
\hline André Luiz Camargo & $\begin{array}{l}\text { O Rapto das Cebolinhas } \\
\text { Cia Pererião } \\
\text { E.E. Chico Pereira } \\
\text { Tatuí } \\
\text { Diretor }\end{array}$ & $\begin{array}{l}\text { OPalhaco era meu tio } \\
\text { Cia Pererião } \\
\text { E.E. Chico Pereira } \\
\text { Tatuí } \\
\text { Diretor }\end{array}$ & $\begin{array}{c}\text { A Vaca Lelé } \\
\text { Cia Teatral Quatro Cantos de Quadra } \\
\text { E.E. da Quadra } \\
\text { Quadra } \\
\text { Diretor }\end{array}$ & $\begin{array}{c}\text { Plutt, O Fantasminha } \\
\text { Grupo Vagalum Tum Tum } \\
\text { E.E. Vereador Egildo Paschoalucci } \\
\text { Pererias } \\
\text { Diretor }\end{array}$ & 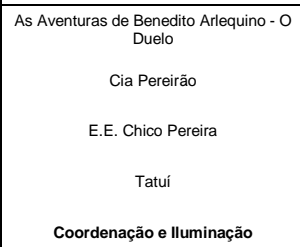 & $\begin{array}{l}\text { O Fantástico ouelo entre Zé da Égua e } \\
\text { Joâo da Estrada } \\
\text { Trupe Cata-Vento } \\
\text { Colégio Anglo } \\
\text { Boituva } \\
\text { Contra-Regra }\end{array}$ & $\begin{array}{l}\text { O Macaco Malandro } \\
\text { Grupo de Tearto Amador de Pereriras } \\
\text { E. E. Ver Egildo Paschoalucci } \\
\text { Pereiras } \\
\text { Direçăo }\end{array}$ \\
\hline Thiago de Castro Leite & $\begin{array}{l}\text { O Rapto das Cebolinhas } \\
\text { Cia Pereirão } \\
\text { E.E. Chico Pereira } \\
\text { Tatuí } \\
\text { Ator/Cenografia }\end{array}$ & $\begin{array}{l}\text { OPalhaço era meu tio } \\
\text { Cia Perierão } \\
\text { E.E. Chico Pereira } \\
\text { Tatúi } \\
\text { Ator/Cenografia }\end{array}$ & $\begin{array}{l}\text { Os dois Turröes } \\
\text { Cia Pereriãa } \\
\text { E.E. Chico Pereira } \\
\text { Tatuí } \\
\text { Assist. de Direção }\end{array}$ & $\begin{array}{l}\text { Espelho de Quem Về } \\
\text { Cia Batalão (do) Brado } \\
\text { Colégio Ânglo } \\
\text { Tatúi } \\
\text { Iluminação }\end{array}$ & $\begin{array}{l}\text { A Incrivel Viagem de Bartolomeu } \\
\text { Cia Batalăo (do) Brado } \\
\text { Colégio Ânglo } \\
\text { Tatuí } \\
\text { Direção }\end{array}$ & $\begin{array}{l}\text { O Fantástico oduelo entre Zé da Égua e } \\
\text { Joầ da Estrada } \\
\text { Trupe Cata-Vento } \\
\text { Colégio Anglo } \\
\text { Boituva } \\
\text { Direção }\end{array}$ & $\begin{array}{l}\text { Joriāo e Romilda } \\
\text { Trupe Cata-Vento } \\
\text { Colégio Anglo } \\
\text { Boituva } \\
\text { Direção }\end{array}$ \\
\hline Jane Kastorsky & & & $\begin{array}{l}\text { Lendas - O Pentagono Grego } \\
\text { Cia de Teatro Uta } \\
\text { E.E. Afonso Vergueiro } \\
\text { Salto de Pirapora } \\
\text { Assist. de Direção }\end{array}$ & $\begin{array}{l}\text { O Tartufo } \\
\text { Cia de Tearto Uta } \\
\text { E.E. Afonso Vergueiro } \\
\text { Salto de Pirapora } \\
\text { Direção }\end{array}$ & $\begin{array}{l}\text { Tucunaré, a filiha da Lua } \\
\text { Cia de Teatro Uta } \\
\text { E.E. Atonso Vergueiro } \\
\text { Salto de Pirapora } \\
\text { Direção }\end{array}$ & $\begin{array}{l}\text { Uma Lenda da Amazônia } \\
\text { Cia de Teatro Uta } \\
\text { E.E. Afonso Vergueiro } \\
\text { Salto de Pirapora } \\
\text { Direção }\end{array}$ & $\begin{array}{l}\text { Tistu } \\
\text { Cia de Tearto Uta } \\
\text { E.E. Atonso Vergueiro } \\
\text { Salto de Pirapora } \\
\text { Direção }\end{array}$ \\
\hline Chico Neto & $\begin{array}{l}\text { Soltando o Verbo/O Caixeiro da } \\
\text { Taverna } \\
\text { Família Matula de Teatro } \\
\text { E.E. Prof. Lauro Sanchez } \\
\text { Sorocaba } \\
\text { Ator e Cenografia }\end{array}$ & $\begin{array}{c}\text { Namoro } \\
\text { Familia Matula de Teatro } \\
\text { E.E. Prof. Lauro Sanchez } \\
\text { Sorocaba } \\
\text { Diretor/Ator }\end{array}$ & $\begin{array}{l}\text { O rapto do Papai Noel } \\
\text { Familia Matula de Teatro } \\
\text { E.E. Prof. Lauro Sanchez } \\
\text { Sorocaba } \\
\text { Autor/Diretor/Ator }\end{array}$ & & & & \\
\hline Valéria de Oliveira & & $\begin{array}{c}\text { O Mambembe } \\
\text { Grupo Tal \& Pá } \\
\text { E.E. Maria Augusta de Ávila } \\
\text { Sāo Paulo } \\
\text { Direção }\end{array}$ & $\begin{array}{l}\text { OArauto da Liberdade } \\
\text { Grupo Tal \& Pá } \\
\text { E.E. Maria Augusta de Avila } \\
\text { Săo Paulo } \\
\text { Direção }\end{array}$ & $\begin{array}{l}\text { O Último Carro } \\
\text { Grupo Tal \& Páa } \\
\text { E.E. Maria Augusta de Ávila } \\
\text { Sãö Paulo } \\
\text { Direcão }\end{array}$ & $\begin{array}{l}\text { Arena Contra Zumbi } \\
\text { Grupo Tal \& Páa } \\
\text { E.E. Maria Augusta de Avila } \\
\text { São Paulo } \\
\text { Direçāo }\end{array}$ & $\begin{array}{c}\text { Motor Boy } \\
\text { Grupo Tal \& Páa } \\
\text { E.E. Maria Augusta de Ávila } \\
\text { São Paulo } \\
\text { Direçāo }\end{array}$ & \\
\hline
\end{tabular}


FREQUENCIA DE PARTICIPAÇÃO

\begin{tabular}{|c|c|c|c|c|c|c|c|}
\hline & $1^{0}$ & $2^{0}$ & $3^{\circ}$ & $4^{\circ}$ & $5^{\circ}$ & $6^{\circ}$ & $7^{0}$ \\
\hline Pámela Paz & $\begin{array}{c}\text { Geração Coca-Cola } \\
\text { Grupo Teen } \\
\text { Colégio Santo Agostinho } \\
\text { São Paulo } \\
\text { Direção } \\
\end{array}$ & $\begin{array}{c}\text { A Incrivel viagem pelo Corpo Humano } \\
\text { Grupo Teen } \\
\text { Colégio Santo Agostinho } \\
\text { São Paulo } \\
\text { Direçāo } \\
\end{array}$ & $\begin{array}{l}\text { Mais quero um asso que me carregue } \\
\text { do que un cavalo que me derrunbe } \\
\text { Grupo Teen } \\
\text { Colégio Santo Agostinho } \\
\text { São Paulo } \\
\text { Direçăo } \\
\end{array}$ & $\begin{array}{l}\text { A Revolta dos Perus } \\
\text { Grupo Teen } \\
\text { Colégio Santo Agostinho } \\
\text { São Paulo } \\
\text { Direção }\end{array}$ & & $\begin{array}{c}\text { José Sonhador e seu maravilihoso } \\
\text { casaco de sonhos colorido } \\
\text { Grupo Teen } \\
\text { Colégio Santo Agostinho } \\
\text { São Paulo } \\
\text { Direção } \\
\end{array}$ & \\
\hline Fabio Jurera & & & . & $\begin{array}{c}\text { O Circo Illusão } \\
\text { Grupo Tapanaraca } \\
\text { Instituto Peixoto Gomida } \\
\text { Itapetininga } \\
\text { Direção } \\
\end{array}$ & $\begin{array}{c}\text { O Fantástico Mistério da Feiurinha } \\
\text { Grupo Tapanaraca } \\
\text { Instituto Peixoto Gomida } \\
\text { Itapetininga } \\
\text { Direção }\end{array}$ & $\begin{array}{l}\text { As aventuras de Peter e Wendy } \\
\text { Grupo Tapanaraca } \\
\text { Instituto Peixoto Gomida } \\
\text { Itapetininga } \\
\text { Direção }\end{array}$ & $\begin{array}{l}\text { A Lenda de Plutt / Macbhet } \\
\text { Grupo Tapanaraca } \\
\text { Instituto Peixoto Gomida } \\
\text { Itapetininga } \\
\text { Direção }\end{array}$ \\
\hline Tânia Boy & & 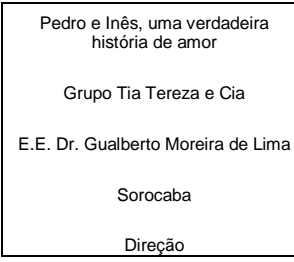 & $\begin{array}{l}\text { Meu Cordel Estradeiro } \\
\text { Grupo Tia Tereza e Cia } \\
\text { E.E. Dr. Gualberto Moreira de Lima } \\
\text { Sorocaba } \\
\text { Direção } \\
\end{array}$ & $\begin{array}{l}\text { Quem Casa, quer casa, ou não? } \\
\text { Grupo Tia Tereza e Cia } \\
\text { E.E. Dr. Gualberto Moreira de Lima } \\
\text { Sorocaba } \\
\text { Direçăo } \\
\end{array}$ & \begin{tabular}{|c} 
A História de Fruk \\
Grupo Tia Tereza e Cia \\
E.E. Dr. Gualberto Moreira de Lima \\
Sorocaba \\
Texto / Direção \\
\end{tabular} & $\begin{array}{l}\text { Quem te Contava Histórias } \\
\text { Grupo Tia Tereza e Cia } \\
\text { E.E. Dr. Gualberto Moreira de Lima } \\
\text { Sorocaba } \\
\text { Texto / Direção }\end{array}$ & \\
\hline Erika Bodstein & & & & & $\begin{array}{l}\text { Geraçăo Coca-Cola } \\
\text { Grupo de Teatro Cilzinho } \\
\text { Colégio Imperatriz Leopoldin } \\
\text { São Paulo } \\
\text { Direçăo }\end{array}$ & $\begin{array}{c}\text { Peter Pan } \\
\text { Grupo de Teatro Cilzinho } \\
\text { Colégio Imperatriz Leopoldin } \\
\text { São Paulo } \\
\text { Direcăo }\end{array}$ & $\begin{array}{l}\text { Sonho de Uma Noite de Verão } \\
\text { Grupo de Teatro Cilzinho } \\
\text { Colégio Imperatriz Leopoldin } \\
\text { São Paulo } \\
\text { Direcaăo }\end{array}$ \\
\hline Benemeri Sulivan & & & & & & $\begin{array}{l}\begin{array}{c}\text { Quem casa, quer casa, ou năo? } \\
\text { Liberdade, Liberdade }\end{array} \\
\text { Cia Quatro Cantos de Quadra } \\
\text { E.E. da Quadra } \\
\text { Quadra } \\
\text { Direcãa }\end{array}$ & $\begin{array}{c}\begin{array}{l}\text { Quem casa, quer casa, ou não?/ } \\
\text { Liberdade, Liberdade }\end{array} \\
\text { Cia Quatro Cantos de Quadra } \\
\text { E.E. da Quadra } \\
\text { Quadra } \\
\text { Direcão }\end{array}$ \\
\hline
\end{tabular}


TENDÊNCIA DE PARTICIPAÇÃO

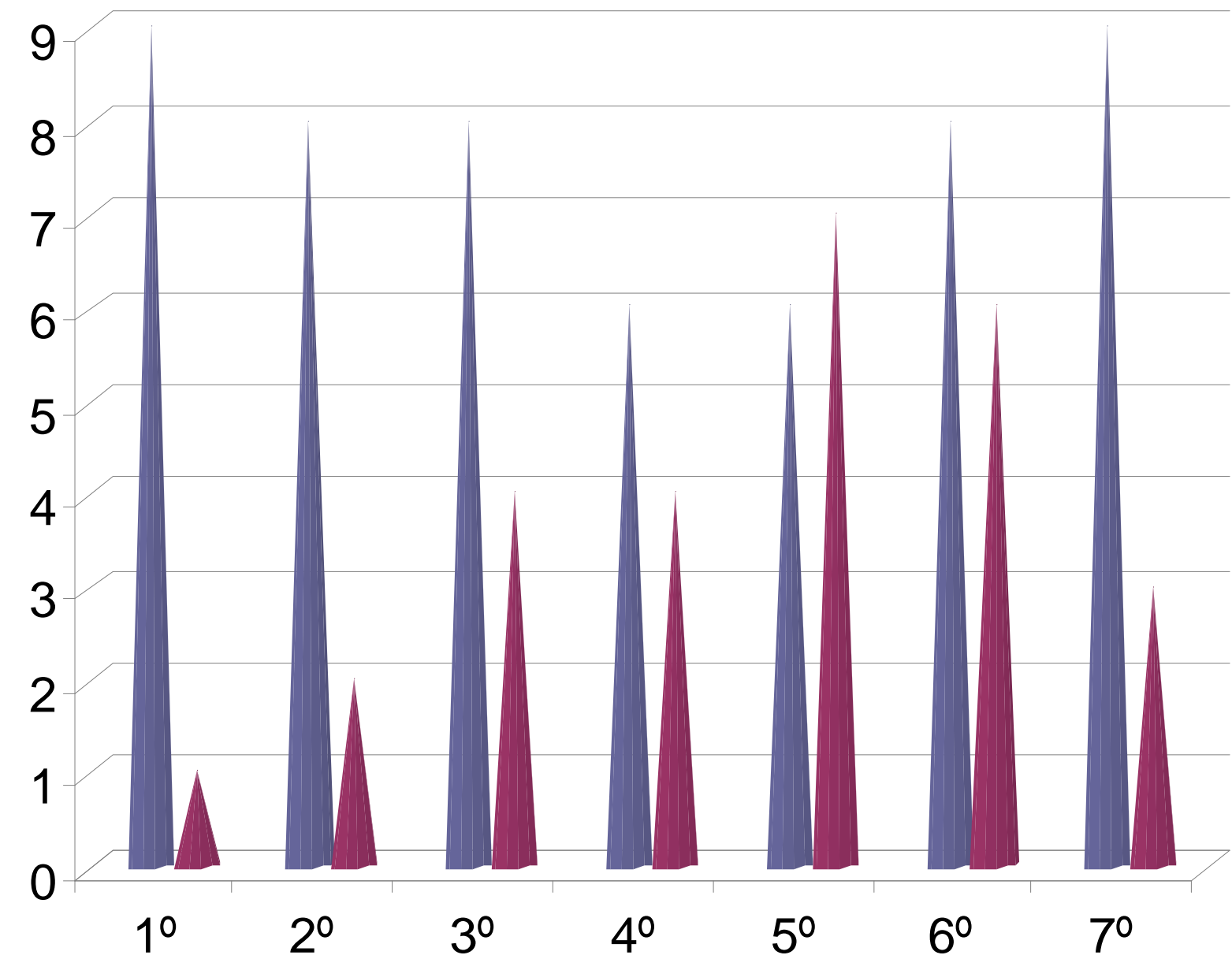

Escola Estadual

- Colégio Particular 


\section{CONCLUSÃO}

O teatro e sua linguagem é um território plural, de uma conquista histórica. É possível encontrar nele a elaboração dos tempos, a complexidade dos espaços, a dramaticidade da construção psicológica dos personagens que deixa transparecer as contradições da sociedade. Teatro é arte e expressão artística. É o espelho da sociedade, é o nosso próprio espelho, quase a elaboração de um sistema que não se sistematiza, que não se submete aos padrões acadêmicos ainda que possa ser aprendido na academia. É na procura constante da transparência do gesto social e ao mesmo tempo ilustrativo que o teatro vive e se alimenta. Seus signos de construção são os signos de representação simbólica da própria vida.

O teatro é um produto criado e produzido por artistas (profissionais ou amadores), cuja finalidade última é permitir ao espectador a fruição de um produto acabado que the dê a possibilidade de sentir e interpretar mensagens de ordem estética, social, política etc. Aqui se vê o teatro como fim.

Para além da perspectiva antes referida, temos o teatro como processo de educação. Neste caso, a sua finalidade é educativa, formadora, que apela para a participação das comunidades no sentido de desbravar caminhos para as práticas teatrais ou sócio-educativas em qualquer espaço. Aqui temos o teatro como meio. O teatro é capaz de contribuir acentuadamente para um desenvolvimento sócio-cultural e educativo local e regional, seja nos aspectos da participação das populações na vida cultural das suas comunidades, seja na fruição de práticas artísticas e na ainda no aumento potencial dos hábitos culturais.

As atividades vinculadas ao teatro possibilitam ao jovem ter conhecimentos e meios para agir e levá-lo a acreditar que são as pequenas coisas que os tornam únicos e interessantes, por isso é importante promover nele, através de práticas motivadoras, atitudes de alteridade, de cooperação para que possa participar ativamente da vida cidadã. 
A expressividade dramática evidencia a tendência do ser humano para a representação, experimentando papéis e vivendo situações. A capacidade de representação dramática está presente tanto nos jogos de faz-de-conta quanto num espetáculo de teatro representado por atores profissionais, assumindo diferentes formas que se desenvolvem através de um processo evolutivo e construtivo, da criança até o artista adulto (KOUDELA, 2002, p.235)

O teatro no Brasil, segundo Décio de Almeida Prado, nasceu com as representações trazidas e realizadas pelos jesuítas da Cia de Jesus com fins catequéticos, segundo os modelos medievais de Milagres e Mistérios. Um dos textos mais interessantes que nos chegaram foi escrito por Padre José de Anchieta (1534-1597) - Na Festa de São Lourenço, de 1583. Neste texto a cultura brasileira aparece pulverizada, fragmentada e mesclada à cultura européia. Preso ao gosto europeu é também o teatro do ciclo da mineração, que em um breve florescimento do cotidiano cultural urbano das Minas Gerais do século XVIII procurou encenar Molière e Calderón. O fim do século presencia a proliferação de Casas de Ópera, que assombravam os viajantes, dada a sua precariedade e improvisação.

Com a vinda da Família Real para o Brasil, em 1808, surge o Teatro São João, depois São Pedro. Hoje, conhecido como teatro João Caetano, em homenagem ao grande e conhecido ator. Ainda no século XIX, destacam-se Martins Pena e França Júnior, com seu teatro de costumes. Vem à cena a cultura do homem brasileiro, do homem do campo e da cidade e suas vicissitudes. Fica mais clara a tensão de linguagem entre o erudito e o popular. Tais contradições revelam que a luta cultural pela afirmação do "estilo brasileiro", tema que por razões óbvias era discutido pela elite do país que partia de um conceito idealizado do vaqueiro e do homem do campo. Dessa idealização foi que se criaram os símbolos de nacionalidade.

O teatro nacional não ficou indiferente à inquietação causada pelas crises econômicas do início do século XX. A crise de 1929 deixou rastro no desenvolvimento da cultura brasileira, trouxe uma sombra de insegurança, de dúvida e perplexidade em todos os setores da sociedade. Restabelecido o 
equilíbrio, o teatro volta a brilhar, agora, com a força dos diretores. Surge, neste contexto, o TBC - Teatro Brasileiro de Comédia trazendo à baila um teatro de proposta e postura mais integrada, mais envolvida com as questões polêmicas do cenário político-econômico.

A grande originalidade, em relação ao TBC e tudo o que este representava, era não privilegiar o estético, não o ignorando mas também não o dissociando do panorama social em que o teatro deve se integrar. Desta postura inicial, deste "engajamento" - palavra lançada antes por Sartre - é que adviriam os traços determinantes do grupo, o esquerdismo, nacionalismo e o populismo (em algumas de suas acepções), a tal ponto entrelaçados que apenas a abstração conseguirá separá-los. (PRADO, 1988, p.63)

É neste cenário que nasce o Teatro Estudantil (ou estudante) pelas mãos de Paschoal Carlos Magno com ajuda de Renato Viana, no Rio de Janeiro, trazendo renovações nos padrões cênicos o que contribuiu para os alicerces do teatro-didático brasileiro.

Na segunda metade do século XX, surge o Teatro de Arena, este sim bastante politizado. Um teatro preocupado em criar fóruns de discussão política, de participar ativamente das manifestações político-sociais. Uma proposta clara de um teatro engajado politicamente que vai procurar intervir na sociedade, principalmente junto aos mais humildes. Brota um sentimento de classe, surgem textos que retratam a desigualdade econômica e social. Desejava-se fazer um teatro rápido, ágil, improvisado a várias mãos, sem pretensões, capaz de atender às necessidades imediatas da propaganda revolucionária, de esmiuçar temas ideológicos e de servir de base pretexta aos comícios.

É importante lembrar que o Teatro Universitário não tinha uma linha ideológica definida, amarrada, seu objetivo era fazer teatro, qualquer que fosse: como diversão, sem grandes revoluções cênicas. Acreditava-se contribuir para criar novas mentalidades, dando apoio aos estudantes. Críticos e governo de 
certa forma também apoiavam o teatro estudantil. Os espetáculos estavam sempre lotados e contavam com a boa recepção do público.

O Teatro do Estudante do Brasil - TEB trouxe grandes contribuições para o desenvolvimento de uma nova linguagem no cenário teatral brasileiro: a formação de elencos para a apresentação de espetáculos em lugares públicos da cidade; orientação técnica para atores e atrizes. É importante lembrar de Paschoal Carlos Magno, alguém que sempre valorizou a improvisação inerente à atividade amadora, foi reconhecidamente um pioneiro na expansão, inclusive geográfica, dos festivais em todo o território brasileiro.

A partir de 1959, Paschoal fez multiplicar, nas capitais e regiões do país, os festivais, que se desdobraram em mesas-redondas, seminários, palestras e exposições sobre o fazer teatral. Esse fervor cultural motiva o surgimento de grupos estudantis ou universitários no cenário brasileiro.

O esforço de Paschoal fez com que passassem a existir definitivamente os festivais estudantis. Em São Paulo, surge o Festival Estudantil de Teatro do Estado de São Paulo, oficializado por meio do decreto estadual 18.434/82, movimento que deu oportunidade para jovens estudantes mostrarem os resultados de estudos e experiências teatrais.

$\mathrm{Na}$ cidade de Tatuí, surgiram grupos de teatro infantil e adulto, formados por estudantes do ensino fundamental e ensino médio, tais grupos estimularam o gosto pelas artes cênicas e foram de grande importância para a formação de público e expansão do teatro por meio de workshops e oficinas.

Neste contexto, a pesquisa ateve-se em demonstrar o papel e a importância do Festival Estudantil Sesi Sorocaba de Teatro. Tal festival é realizado anualmente, tendo como público-alvo crianças e adultos. Durante todo o período em que estive a frente do Núcleo de Artes Cênicas do Sesi Sorocaba, tive a preocupação de desenvolver um trabalho que possibilitasse desenvolver questões ligadas aos aspectos sócio-políticos e pedagógicos do fazer teatral.

Reconheço o papel transformador do teatro, na pedagogia teatral como nos afirma Koudela, quando diz que 
A pedagogia do teatro incorpora tanto a investigação dobre a teoria e a prática da linguagem artística do teatro, quanto a sua inserção nos vários níveis e modalidades de ensino. (....) Outra tendência verificada em várias pesquisas é o teatro como ação cultural. Problemas sociais contemporâneos, como as drogas, o meio-ambiente e a violência têm surgido como temas privilegiados nos trabalhos realizados com crianças e adolescentes. (...) A apreciação e análise, por parte das crianças e jovens, de espetáculos teatrais de qualidade, bem como a participação em eventos artísticos, é uma forma de trabalhar a construção de valores estéticos e o conhecimento de Teatro. (GUINSBURG, 2006, p.239)

Por acreditar na fundamental importância da pedagogia do teatro que defendo o valor dos festivais porque por meio deles percebeu-se o valor do teatro enquanto simulacro da realidade. Foi possível demonstrar os procedimentos de construção da linguagem teatral e seus signos fundantes. $E$ o melhor, associá-los ao fazer pedagógico. Teatro e educação podem caminhar juntos, apesar das dificuldades que perpassam os caminhos de tal construção.

E foi acreditando nisso que criei o Festival Estudantil do Sesi Sorocaba, com objetivo de estimular o interesse dos alunos e revelar novos talentos através dos núcleos formados na escolas públicas e particulares. Para formatar a estrutura, foram convidados intelectuais com trabalhos relevantes ligados ao teatro, patrocinadores e, por fim, em 14 de setembro de 2002 iniciou-se o festival com a apresentação de dez grupos.

A partir desta data, anualmente realizamos festivais de teatro que contam com o envolvimento e a participação de mais pessoas para assistir às apresentações, de grupos de teatro antigo que nos acompanham, desde o primeiro festival, e novos grupos que aparecem para concorrer.

Os festivais têm tornado transparente o envolvimento e a relação simbiótica gerada entre professores artistas e as dificuldades dos grupos envolvidos neste processo e se faz presente em sua trajetória até os dias de hoje. Por isso, foram selecionados grupos de extrema relevância para a minha pesquisa, a saber: o Grupo Teen de Teatro Santo Agostinho de São Paulo, sob a responsabilidade da professora Pámela Larenas Paz; Grupo Cia. de Teatro Uta, da Escola E.E Dr. Afonso Vergueiro, na cidade de Salto de Pirapora-SP, sob a responsabilidade da professora Jane Kastorsky; o Grupo Trupe 
Catavento, do Colégio Anglo Boituva, da cidade Boituva-SP, sob a responsabilidade do professor Thiago Leite; o Grupo Teatral Tapanaraca, da cidade de Itapetininga-SP e a Cia. de Teatro Tal\&Pá da Escola Estadual Professora Maria Augusta de Ávila, em Artur Alvim, Zona Leste de São Paulo, sob a responsabilidade da professora Valéria de Oliveira.

Nossa meta é trabalhar o festival estudantil como instrumento proliferador das artes cênicas entre os jovens estudantes. O desejo é fazê-los perceber o teatro como instrumento de trabalho no processo global de educação, e o componente lúdico é o primeiro princípio pedagógico que permite a aprendizagem. Participar de um festival é uma vivência de partilha e de experimentação determinante para que os jovens assumam novas atitudes e comportamentos. A sua prática desenvolve competências de trabalho em grupo, estimula o conhecimento de si mesmo na relação com os outros; promove o reconhecimento, a confiança a e a valorização do outro; gera motivação e faz com que se busque soluções para diversas situações.

A prática dos festivais permite a assimilação de novos conteúdos, estimula a o questionamento, daí constituir uma poderosa ajuda na aquisição de conhecimentos. Habilita para uma adaptação constante a diferentes situações e gera desafios para a construção de um trabalho em equipe. Tal experiência pode contribuir para a melhoria dos laços de convivência, possibilitando um caminhar em sociedade mais tolerante, criativo e participativo.

Essa pesquisa serviu-me para ratificar a importância didáticopedagógica dos festivais estudantis de teatro e isso pode ser confirmado pelos depoimentos das pessoas envolvidas. $O$ que percebemos de comum entre todos os depoimentos são as dificuldades de ordem financeira para a efetivação dos grupos. Nas escolas públicas até se percebe um envolvimento maior dos docentes, de familiares e da própria comunidade. Todos ajudam como podem na infra-estrutura do espetáculo. Nas escolas particulares, os depoimentos afirmam que muitas vezes houve dificuldades para garantir a participação dos alunos, pois nem sempre a direção pedagógica ou administrativa assume integralmente a gerência do teatro enquanto uma atividade pedagógica. 
Nos depoimentos das professoras dos grupos é visível o reconhecimento do trabalho realizado pelo Festival do Sesi Sorocaba, uma vez que a estrutura do festival considera o processo do trabalho educacional realizado pelo professor. A proposta do festival desenvolve um trabalho educacional com os adolescentes, possibilitando uma postura crítica, incentivando o resultado final do processo. Em todos os festivais os alunos podem participar de oficinas e dos debates no final de cada apresentação

Os festivais são importantes porque dão ênfase no processo de criação em si, não visam a apenas o produto final - o espetáculo. No entanto, a finalização de uma montagem teatral e o fato de participar de um grande evento desperta a valorização das metas a serem atingidas e a consciência da cumplicidade de um trabalho em grupo. E o mais importante é ver a escola como um espaço representativamente cultural, é ver que o seu valor extrapola a sala de aula e as atividades de rotina pedagógica e passa a ser vista como um espaço verdadeiramente comunitário e aberto às discussões estéticopedagógicas juntando todos numa causa comum.

De tudo o que foi dito, queremos ressaltar a necessidade e a pertinência de repensar práticas educativas que se constituam como instrumentos formativos e formadores de aprendizagem para o exercício da cidadania, conceito que hoje se associa ao de aquisição de competências e a capacidade de utilizar o que foi aprendido, reafirmando o teatro como prática facilitadora de desenvolvimento pessoal e social.

Concluímos com a pesquisa que a identidade de um grupo teatral se dá pela construção coletiva, pelo fazer cúmplice participativo, pela solidariedade e comprometimento com os aspectos lúdico-pedagógicos. A escola, a comunidade, as instituições preocupadas com a melhoria da qualidade vida e com a arte. Os Festivais Estudantis de Teatro do Sesi Sorocaba deram vazão ao fazer teatral de cada grupo, respeitando as especificidades e as dificuldades dos mesmos. O que é inquestionavelmente interessante nestes festivais é perceber a diversidade de valores, de informações, manifestações culturais sem juízo valorativo de mensura. 
Os Festivais Estudantis realizados em Sorocaba têm fornecido meios aos estudantes para agir e acreditar que são as pequenas coisas que os tornam únicos e interessantes, por isso é necessário estimular a participação e promover através de práticas motivadoras, atitudes de alteridade, de cooperação e de conhecimento, para que participem ativamente de suas responsabilidades com a escola e com a sociedade. 


\section{BIBLIOGRAFIA}

AGUIAR, Teresa. O Teatro no Interior Paulista. SP: T.A.Queiroz, 1999 ARRABA, José (org.) DIONYSOS - Teatro Duce. MEC/Funarte/Serviço Nacional de Teatro. №23, setembro de 1978.

AZEVEDO, Elizabeth R.. Um Palco sobre Arcadas. SP: Fapesp, 2000. AZEVEDO, Sônia Machado. No campo feito de sonhos: Núcleo de artes cênicas do SESI - $O$ cidadão criador, um estudo de inserção social através da arte e da educação estética. SP: ECA/USP, 2005, tese de livre docência.

BARBOSA, Ana Mae. Arte-Educação no Brasil. SP: Perspectiva, 1999. BELINKY, Tatiana. A história de uma contadora de histórias. Dissertação apresentada ao programa de pós-graduação em Artes na Escola de Comunicação e Artes da Universidade de São Paulo, 2008 BOAL, Augusto. Jogos para atores e não atores. RJ: Civilização Brasileira. 1999.

CLAPARÈDE, Edouard. A Escola Sob Medida. RJ: Editora Fundo de Cultura. 1959.

COURTNEY, Richard. Jogo, Teatro \& Pensamento. SP: Perspectiva, 2001. DESGRANGES, Flávio. A pedagogia do espectador. SP: Hucitec, 2003. FOUCAULT, Michel. Vigiar e Punir. RJ: Vozes, 2003.

GARCIA, Clóvis. Os caminhos do teatro paulista. SP: Prêmio, 2006. GUINSBURG, J. Da Cena em Cena. SP: Perspectiva, 2001. FARIA, José Roberto e LIMA, Mariangela Alves de. Dicionário do Teatro Brasileiro. Temas, formas e conceitos. São Paulo:

Perspectiva/SESC, 2006

GUZIK, Alberto e PEREIRA, Maria Lúcia (orgs.) DIONYSOS - Teatro Brasileiro de Comédia. MEC/Funarte/Serviço Nacional de Teatro. №25, setembro de 1980. 
KOUDELA, Ingrid Dormien. Brecht: um jogo de aprendizagem. SP: Perspectiva, 1991.

. Jogos teatrais, SP: Perspectiva, 1984.

. Um vôo brechtiano, SP: Perspectiva, 1992.

. Texto e Jogo, SP: Perspectiva, 1996.

. "A nova proposta de ensino do teatro" in Sala Preta

- Revista do Departamento de Artes Cênicas - ECA-USP, oㅡ 2 , SP: Edusp. 2002.

MACHADO, Maria Clara. Biblioteca Educação e Cultura, vol. 7 - Teatro II, RJ: FENAME, 1980.

, Maria Clara. Teatro III, RJ: Agir, 1997.

Maria Clara. Teatro VI. RJ: Agir, 1999

MICHALSKI, Yan. "Itália Fausta" In Pequena Enciclopédia do Teatro

Brasileiro Contemporâneo. RJ. 1989

MOSKO, Junior. O Teatro da Criança, pela Criança, para a Criança. SP. Ottoni. 2008.

PAVIS Patrice. Dicionário do Teatro. SP: Perspectiva, 1999.

PIAGET, J. O nascimento da inteligência na criança. RJ: Zahar, 1978.

PRADO, Décio de Almeida. "Chá e Simpatia" In Teatro em Progresso. SP: Martins, 1964

PUPO, Maria Lúcia de Souza Barros. Palavras em jogo: textos literários e teatro educação. SP: ECA/USP, 1997, tese de livre docência.

. No reino da desigualdade. SP: Perspectiva, 1991.

SLADE, Peter. O Jogo Dramático Infantil, SP: 1978.

RYNGAERT, Jean Pierre. Introdução à análise do teatro. SP: Martins Fontes, 1996.

SPOLIN, Viola. Improvisação para o teatro. SP: Perspectiva: 2000.

. O jogo teatral no livro do diretor. SP: Perspectiva, 2001. 
. Jogos teatrais, o fichário de Viola Spolin. SP: Perspectiva,

2001.

Jogos Teatrais na sala de aula. SP: Perspectiva, 2007.

MINISTÉRIO DA EDUCAÇÃO E CULTURA, DAC - FUNARTE, Dionysos,

Especial do Estudante do Brasil, Teatro Universitário - Teatro Duse, Serviço Nacional do Teatro, 1978. 